\title{
COMPARATIVE \\ PERSPECTIVES ON GENDER EQUALITY IN JAPAN AND NORWAY
}

\section{SAME BUT DIFFERENT?}

\author{
Edited by
}

Masako Ishii-Kuntz, Guro Korsnes Kristensen

and Priscilla Ringrose

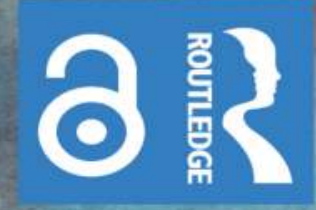




\section{Comparative Perspectives on Gender Equality in Japan and Norway}

This book compares perspectives on gender equality in Norway and Japan, focusing on family, education, media, and sexuality and reproduction as seen through a gendered lens. What can we learn from a comparison between two countries that stand in significant contrast to each other with respect to gender equality? Norway and Japan differ in terms of historical, cultural and socioeconomic backgrounds. Most importantly, Japan lags far behind Norway when it comes to the World Economic Forum's Gender Gap Report. Rather than taking a narrow approach that takes as its starting point the assumption that Norway has so much 'more' to offer in terms of gender equality, the authors attempt to show that a comparative perspective of two countries in the West and East can be mutually beneficial to both contexts in the advancement of gender equality. The interdisciplinary team of researchers contributing to this book cover a range of contemporary topics in gender equality, including fatherhood and masculinity, teaching and learning in gender studies education, cultural depictions of gender, trans experiences and feminism. This unique collection is suitable for researchers and students of gender studies, sociology, anthropology, Japan studies and European studies.

Masako Ishii-Kuntz is Trustee/Vice President and Professor Emeritus of Ochanomizu University. Her specialties include family sociology and gender studies, and her research focuses on men's childcare and housework and women's labour force participation. She was the President of the Japan Society of Family Sociology (2016-2019) and a board member of the Japan Sociological Society. She was a member in the United Nations Expert Group meeting and in the Gender Equality Bureau Cabinet Office's committee. In recognition of her contribution to the international research and teaching of family sociology, she received the 2012 Jan Trost Award of the National Council on Family Relations in the US. Her publications include, among others, Sociology of Childcaring Men (2013) and Family Violence in Japan (2016).

Guro Korsnes Kristensen is Professor in Gender, Equality and Diversity Studies in the Department of Interdisciplinary Studies, the Norwegian University of Science and Technology (NTNU). She holds an MA in Social Anthropology and a PhD in Gender Studies, and her research areas are reproduction, gender equality, immigration and integration. Kristensen is the project manager of the research project 'Norway-Japan: Bridging Research and Education in Gender Equality and Diversity' (2019-2022) funded by the Norwegian Research Council.

Priscilla Ringrose is Professor of Gender Studies at the Norwegian University of Science and Technology. She has led two Norwegian Research Council-funded projects on Paid Domestic Labour and on Integration of Adolescent Migrants. She has co-edited three anthologies: Paid Migrant Domestic Labour in a Changing Europe (2016), Fundamentalism, Globalism and the Public Sphere (2011) and Fundamentalism and Communication: Culture, Media and the Public Sphere (2011). She has published widely on topics including migration and gender, migration and education, domestic labour, new media and Middle East war, Islamic fundamentalisms, intercultural cinema and 20th-century francophone literature. 


\section{Global Gender}

The Global Gender series provides original research from across the humanities and social sciences, casting light on a range of topics from international authors examining the diverse and shifting issues of gender and sexuality on the world stage. Utilising a range of approaches and interventions, these texts are a lively and accessible resource for both scholars and upper level students from a wide array of fields including Gender and Women's Studies, Sociology, Politics, Communication, Cultural Studies and Literature.

Gender and Australian Celebrity Culture

Edited by Anthea Taylor and Joanna McIntyre

Gender, Sexuality and National Identity in the Lives of British Lifestyle Migrants in Spain

Chasing The Rainbow

Laura Dixon

Women in the Budapest School of Psychoanalysis

Girls of Tomorrow

Anna Borgos

\#MeToo and Cyber Activism in China

Gendered Violence and Scripts of Power

Li Ma

Feminist Organizing across the Generations

Karen Bojar

Comparative Perspectives on Gender Equality in Japan and Norway

Same but Different?

Edited by Masako Ishii-Kuntz, Guro Korsnes Kristensen and Priscilla Ringrose

https://www.routledge.com/Global-Gender/book-series/RGG 


\section{Comparative Perspectives on Gender Equality in Japan and Norway \\ Same but Different?}

Edited by Masako Ishii-Kuntz, Guro Korsnes Kristensen and Priscilla Ringrose 
First published 2022

by Routledge

2 Park Square, Milton Park, Abingdon, Oxon OX14 4RN

and by Routledge

605 Third Avenue, New York, NY 10158

Routledge is an imprint of the Taylor \& Francis Group, an informa business

(C) 2022 selection and editorial matter, Masako Ishii-Kuntz, Guro

Korsnes Kristensen and Priscilla Ringrose; individual chapters, the contributors

The right of Masako Ishii-Kuntz, Guro Korsnes Kristensen and Priscilla Ringrose to be identified as the authors of the editorial material, and of the authors for their individual chapters, has been asserted in accordance with sections 77 and 78 of the Copyright, Designs and Patents Act 1988.

The Open Access version of this book, available at www.taylorfrancis.com, has been made available under a Creative Commons Attribution-Non Commercial-No Derivatives 4.0 license.

Trademark notice: Product or corporate names may be trademarks or registered trademarks, and are used only for identification and explanation without intent to infringe.

British Library Cataloguing-in-Publication Data

A catalogue record for this book is available from the British Library

Library of Congress Cataloging-in-Publication Data

A catalog record has been requested for this book

ISBN: 978-1-032-02779-1 (hbk)

ISBN: 978-1-032-02796-8 (pbk)

ISBN: 978-1-003-18522-2 (ebk)

DOI: $10.4324 / 9781003185222$

Typeset in Sabon

by MPS Limited, Dehradun 


\section{Contents}

List of figures viii

List of tables ix

List of contributors $\quad \mathrm{x}$

Preface and acknowledgements xiv

1 Introduction: Comparative perspectives on gender in Japan and Norway

MASAKO ISHII-KUNTZ, GURO KORSNES KRISTENSEN, AND

PRISCILLA RINGROSE

PART I

Family and home

2 Gender and home in Japan and Norway: Considering the past and contemplating the future

GURO KORSNES KRISTENSEN, PRISCILLA RINGROSE, AND MASAKO ISHII-KUNTZ

3 Caring masculinity: Fathers' childcare in Japan and Norway

MASAKO ISHII-KUNTZ

PART II

Education

4 Education and gender in Japan and Norway from historical perspective RYOKO KODAMA 
vi Contents

5 Creating more equal partnerships: Home Economics education and gender equality in Japan and Norway JENNIFER BRANLAT AND JUNKO SANO

6 Teaching with feminist values: A dialogical narrative analysis of gender studies educator narratives JENNIFER BRANLAT

7 Making it in academia: A study of career narratives of men and women professors in Norway and Japan VIVIAN ANETTE LAGESEN, GURO KORSNES KRISTENSEN, SIRI ØYSLEBØ SØRENSEN, AND DEREK MATSUDA

PART III

Media

8 Masculinity in contemporary Viking and Samurai comedies: 'It's not really me, that fear-based leadership style stuff'

JENNIFER BRANLAT AND PRISCILLA RINGROSE

9 Work-life balance and equality observed through advertising during the COVID-19 pandemic in Japan and Norway

CHIHIRO WADA AND ROGER A. SØRAA

PART IV

Sexuality and reproduction

10 The struggle to belong: Trans and gender-diverse experiences in Japan and Norway

FRANCE ROSE HARTLINE AND KEIICHIRO ISHIMARU

11 A matter of gender (in)equality? Public discourses on declining fertility rates in Japan and Norway GURO KORSNES KRISTENSEN AND YUKARI SEMBA

12 Assisted reproduction with donated eggs and sperm: A comparison of regulations on assisted reproduction in Norway and Japan 
PART V

Dialogue

13 Becoming a feminist academic in Japan and Norway: A dialogue with Professors Masako Ishii-Kuntz and Agnes Bolsø

JENNIFER BRANLAT, AGNES BOLS $\varnothing$, AND MASAKO ISHII-KUNTZ

14 Conclusion: Comparative perspectives on gender equality in Japan and Norway: Reflections and lesson learnt

PRISCILLA RINGROSE, MASAKO ISHII-KUNTZ, AND

GURO KORSNES KRISTENSEN

Index 


\section{Figures}

2.1 Norwegian living room 20

2.2 Norwegian kitchen 21

2.3 Traditional Norwegian house 22

2.4 Norwegian house 23

2.5 Norwegian house 24

2.6 Japanese apartment buildings 26

$\begin{array}{ll}2.7 & \text { Japanese house }\end{array}$

2.8 Japanese kitchen 28

2.9 Japanese living room 29

3.1 Percentage of mothers and fathers taking parental leave
in Japan, 2010-2020

3.2 Duration of parental leave for mothers and fathers in Japan $\quad 42$

3.3 Analytical model predicting fathers' childcare involvement 44

4.1 International comparison of higher education enrolment ratios 56

4.2 Gender differences in university enrolment rates in Norway (1971-2020) 59

4.3 Gender differences in university enrolment rates in Japan (1971-2020) 60

4.4 Gender differences in university and junior college enrolment rates in Japan (1954-2020) 61

4.5 Junior college students by major in Japan (1950-2015) 62

4.6 Trend in employment rates of women by age group in Japan, 1968-2010 63

4.7 Comparison of female labour force participation rates Between Japan and Norway

11.1 Total fertility rates in Japan and Norway 174 


\section{Tables}

3.1 Factors Affecting Fathers' Childcare Involvement

5.1 Breakdown of Interviewees by Name, Country, Age and 


\section{Contributors}

Agnes Bolsø is Professor Emerita at the Norwegian University of Science and Technology (NTNU) in Trondheim, Norway. She has been head of the Centre for Gender Research at NTNU, editor of The Norwegian Journal of Gender Studies and involved in the development of Norwegian feminism, Women's Studies and Gender Studies since the 1980s. She has generated a thematically broad academic output on gender, sexuality, and power and politics. Prof. Bolsø is currently pursuing research on trans bodies and femininity, enquiring into the role of symbolic gender in trans transformations.

Jennifer Branlat is a postdoctoral researcher and project leader of the GenderHub network at the Norwegian University of Science and Technology. Her current research projects include: A Pedagogy of Unlearning, which focuses on teaching and learning in Gender Studies, and Beyond Labels: Uncovering the Invisible Dimensions of Exclusion and Inclusion, a microphenomenological study of lived experiences. She has published on gender and film, pedagogy, and teaching and learning in higher education.

france rose hartline has a $\mathrm{PhD}$ in Gender Studies from the Norwegian University of Science and Technology in Trondheim, Norway. His background is in art and sociology, with a focus on queer issues. Originally from New Orleans, US, he currently lives in Norway with his partner and two dogs.

Keiichiro Ishimaru is Associate professor of clinical psychology at Ochanomizu University. He received $\mathrm{BA}, \mathrm{MA}$, and $\mathrm{PhD}$ from the University of Tokyo. He studied several topics concerning LGBTQ, psychology and cognitive behavioural therapies. He is one of the executive board members of Japanese Society of Gender Identity Disorder, and secretary-general of Japan Society of Sexual Science. As a clinical psychologist, he has been working with many transgender people in psychiatric settings.

Masako Ishii-Kuntz is Trustee/Vice President and Professor Emeritus of Ochanomizu University. Her specialties include family sociology and gender studies, and her research focuses on men's childcare and housework and women's labour force participation. She was the President of the Japan Society of Family Sociology (2016-2019) and a board member of the Japan 
Sociological Society. She was amember in the United Nations Expert Group meeting and in the Gender Equality Bureau Cabinet Office's committee. In recognition of her contribution to the international research and teaching of family sociology, she received the 2012 Jan Trost Award of the National Council on Family Relations in the US. Her publications include, among others, Sociology of Childcaring Men (2013) and Family Violence in Japan (2016).

Ryoko Kodama is a Professor of Education and Historical Sociology, Faculty of Core Research Human Science Division, Ochanomizu University and Vice-President of the Gender History Association of Japan. Her recent research has focused on early childhood education and care. She is a member of the group on the study of pedagogical documentation and the ECEC teacher network (JSPS, Fostering Joint International Research). She is also the presidents of the Gender History Association of Japan (2018-2020).

Guro Korsnes Kristensen is Professor in Gender, Equality and Diversity Studies in the Department of Interdisciplinary Studies, the Norwegian University of Science and Technology (NTNU). She holds an MA in Social Anthropology and a $\mathrm{PhD}$ in Gender Studies, and her research areas are reproduction, gender equality, immigration and integration. Kristensen is the project manager of there search project 'Norway-Japan: Bridging Research and Education in Gender Equality and Diversity' (2019-2022) funded by the Norwegian Research Council.

Vivian Anette Lagesen is a Professor in Science and Technology Studies (STS) at the Norwegian University of Science and Technology (NTNU). She has published widely within the topic of gender, science and technology. She has studied inclusion design and inclusion strategies in higher education and software engineering industries in Norway, the US and Malaysia and knowledge management and learning in consulting engineering and in urban planning. Lagesen's current research is on epistemic living spaces among university academics and gender equality measures in universities.

Merete Lie is Professor Emeritus and former head of the Centre for Gender Research at the Norwegian University of Science and Technology (NTNU). She is a social anthropologist and her field of research is feminist technoscience, including ICTs, assisted reproductive technologies, medical imaging and bioart; and research on gender and change in China and Southeast-Asia. Her books include the edited/co-edited volumes Making Technology Our Own? Domesticating Technology into Everyday Life (1996), He, She and IT Revisited: New Perspectives on Gender in the Information Society (2003), The Social Meaning of Children and Fertility Change in Europe (Routledge 2013), and Assisted Reproduction Across Borders: Feminist Perspectives on Normalizations, Disruptions and Transmissions (Routledge 2017). 
Derek Matsuda is a lecturer at Ochanomizu University (Japan). He is in charge of study abroad programs and is currently researching transnational immigrants' education. He has a BA in Policy Studies from Kwansei Gakuin University (Japan) and a MA in Education from Sophia University (Japan). His research has focused on the education and the acculturation of Latin American immigrants in Japan who have Japanese roots. Currently, he is a $\mathrm{PhD}$ candidate at Sophia University (Japan), researching on the influence of immigration on education in the US, Japan and Peru.

Priscilla Ringrose is Professor of Gender Studies at the Norwegian University of Science and Technology. She has led two Norwegian Research Council-funded projects on Paid Domestic Labour and on Integration of Adolescent Migrants. She has co-edited three anthologies: Paid Migrant Domestic Labour in a Changing Europe (2016), Fundamentalism, Globalism and the Public Sphere (2011) and Fundamentalism and Communication: Culture, Media and the Public Sphere (2011). She has published widely on topics including migration and gender, migration and education, domestic labour, new media and Middle East war, Islamic fundamentalisms, intercultural cinema and 20thcentury francophone literature.

Junko Sano is a lecturer at the Research Center for Financial Gerontology, part of the Institute for Economic Studies at Keio University. She is also a visiting researcher at the Institute for Gender Studies (Ochanomizu University). She has a PhD in Social Science from Ochanomizu University and an MA in Women's Labour Economics, Home Studies, and Home Economics (Ochanomizu University). Her current research projects include women's financial behaviour and gender, home economics education and gender equality, and a comparison of working mothers in Japan and Norway.

Yukari Semba is project lecturer at the Institute for Gender Studies, Ochanomizu University. She received her PhD in Human Sciences from Graduate School of Human Science, Waseda University (Japan), and has been doing research in the field of bioethics and gender. She is especially interested in the ethical, social and gender issues regarding reproductive technologies and third-party reproduction.

Roger A. Søraa is a researcher at the Department of Interdisciplinary Studies of Culture (KULT) and Department for Neuromedicine and Movement Science at NTNU Norwegian University of Science and Technology. His main research interests are the digitalization and robotization of society, and the ethical, gendered and epistemological consequences of this. Dr. Søraa is the deputy leader of NTNU's Immersive Technology and Social Robotics laboratory which does research on welfare technology/gerontechnology, and leads a research group on the Digitalization and robotization of society at NTNU KULT. 
Siri Øyslebø Sørensen is a Professor in Gender, Diversity and Equality Studies and the head of the Center for Gender Research at the Norwegian University of Science and Technology (NTNU). Sørensen's research contributes to the fields of organisational studies, policy studies and media studies. She has previously studied the making and implementation of gender quota policies, the career experiences of women managers, media controversies on motherhood and career choices. Recently her research has addressed gender balance and diversity in academic institutions. Sørensen is co-editor of Bodies, Symbols and Organizational Practice: The Gendered Dynamics of Power (Routledge, 2018).

Chihiro Wada is a PhD candidate in the Department of Transdisciplinary Science and Engineering at Tokyo Institute of Technology. Her journal article entitled 'Narratives of Men's Beauty and Masculinity' (2018) focuses on masculinities in Japanese society in the 2010s. Her most recent research interests centre on science and technology studied through a feminist technoscience studies lens. 


\section{Preface and Acknowledgements}

This book is the result of an ambitious, challenging and truly joyful partnership and collaboration between Gender Studies scholars in Norway and Japan. It all started in April 2017, when a delegation from the Norwegian University of Science and Technology, Trondheim (NTNU) arrived in Tokyo with the aim of establishing partnerships with Japanese universities and research groups. The visit was initiated and organized by Dr Hiroshi Matsumoto, who worked with NTNU from his Tokyo office to set up research partnerships between Japan and Norway. The delegation was predominantly made up of researchers in the 'hard sciences' but also included two researchers from the Center for Gender Research, Professors Priscilla Ringrose and Guro Korsnes Kristensen. It was Dr Hiroshi Matsumoto's idea that the delegation from NTNU should include researchers from Gender Studies, as he recognized the mutual interest such a potential collaboration could bring to both national contexts.

In Japan, the Norwegian delegates, including those from Gender Studies, met with members of various departments, groups and organizations. At Ochanomizu University, we were invited to take part in an open symposium organized by the Institute of Gender Studies which attracted a lot of students, faculty and staff. In this symposium, the topics of family/work balance and 'happy Norwegian families' were on the agenda. In the reception following the symposium, Guro Korsnes Kristensen and Priscilla Ringrose were introduced to the director of the Institute for Gender Studies: Professor Masako IshiiKuntz. By the end of the visit, Professors Ishii-Kuntz, Kristensen and Ringrose had already decided to apply for funding to be able to get to know each other better and not least to learn from each other. As a result, in 2018, the two research centres applied to the Norwegian Research Council and the INTPART program (International Partnerships for Excellent Education, Research and Innovation) for funding for a three-year project entitled Norway-Japan: Bridging Research and Education in Gender Equality and Diversity (NJ_BREGED). The objective of the project was to form a partnership with extensive reciprocal mobility activities for both students and staff in Norway and Japan.

Fortunately for both parties concerned, the project was funded, and, in 2019, a delegation from Institute for Gender Studies, Ochanomizu 
University, visited the Center for Gender Studies at NTNU. Following this, international student exchanges took place between the two institutions. However, in March 2020, a couple of months before the next delegation of Norwegian students and staff were to travel to Japan, the emerging COVID-19 situation put an end to all travel plans. For a long time, the project leaders optimistically thought that the situation would mean that the plans would only be postponed for a few months. At the time of writing, it is June 2021 and we have still not been able to meet face to face with our project partners. However, since we had already met both face-to-face and online before travel restrictions came into force, we were able to continue our research collaboration successfully at a distance.

And this is how this book has come about; it is the result of frequent meetings and intensive work conducted online by researchers who were and still are physically confined to their respective nation states, mostly working from home offices and longing for the old normal. We have not got back to the old normal yet, but have found a new normal and, using google meet and zoom, have got to know each other better and not least successfully discussed, revised and encouraged each other online. The resulting exchanges of knowledge have cemented our initial thinking that the project of exploring dimensions of gender equality from this comparative perspective was important for our respective national contexts and fruitful in generating new cross-cultural knowledge.

We would like to thank the Norwegian Research Council and the INTPART program for their generous financial support. We would also like to thank our host institutions, the Norwegian University of Science and Technology and Ochanomizu University, for administrative support throughout the project's life cycle, as well as our colleagues at the Institute for Gender Studies in Tokyo and the Center for Gender Research in Trondheim, where most of the authors are located and without whose contributions this volume would not have been possible.

We would also like to extend our gratitude to Professor Emerita Janice B. Bardsley, from the Department of Asian and Middle Eastern Studies, The University of North Carolina at Chapel Hill, for her excellent comments and suggestions throughout the revision process. We would also like to thank france rose hartline for his flexibility, speedy responses, and very thorough copy editing. Thanks is also due to Kumi Yoshihara, Project Research Fellow at Ochanomizu University, for her extensive administrative help throughout the whole partnership.

We very much hope that the book will inspire researchers and policy makers who have an interest in the practices and policies related to gender equality in Japan, Norway and beyond to appreciate and draw upon the results which this multi-faceted cross-cultural research has borne.

Masako Ishii-Kuntz (Tokyo), Guro Korsnes Kristensen and Priscilla Ringrose (Trondheim) - June 2021 


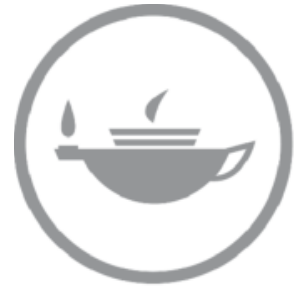

Taylor \& Francis Taylor \& Francis Group http://taylorandfrancis.com 


\title{
1 Introduction: Comparative perspectives on gender in Japan and Norway
}

\author{
Masako Ishii-Kuntz, \\ Guro Korsnes Kristensen, \\ and Priscilla Ringrose
}

\section{Gender equality in Japan and Norway}

Both Japan and Norway are advanced economies with highly developed technological infrastructures. They ranked highly in the United Nation's 2020 'Human Development Index,' which lists Norway at the top and Japan at 19th out of 189 countries and territories (United Nations, 2020). Japan's ranking is the second highest (after Hong Kong) among East Asian countries. Most importantly for the focus of this volume, we note that both the Japanese and Norwegian governments have been making concerted and sustained efforts to promote gender equality at all societal levels.

These two nations, however, differ significantly in terms of historical, cultural, geopolitical and socio-economic backgrounds. We cannot ignore the fact that Japan scores much lower than Norway when it comes to achieving gender parity in economic and political participation as evidenced in the WEF's 'Gender Gap Report' (2021). In line with this, Norway is often portrayed as a pioneer nation in gender equality. Indeed, gender equality is also claimed to be at the core of the Norwegian cultural identity (Danielsen et al., 2013; Gullikstad et al., 2016). Japan, on the other hand, is better known for its lack of gender equality and emphasis on separate gendered spheres, as exemplified by the extensive application of gender segregation. This is somewhat surprising, given that it is a wealthy, secular country with a highly educated population. Additionally, the COVID-19 crisis, and the subsequent closure of children's schools, has widened the gender gap in Japan, accelerating the domestic demands and decreased employment opportunities for women. The pandemic has also had a negative impact on gender equality in the Norwegian context. As Norwegian Prime Minister Erna Solberg declared in her speech about COVID-19 to the Reykjavik Global Forum - Women Leaders 2020, 'The pandemic's impact on women has been evident in our own country as well. We see that unpaid care work at home is not evenly distributed between men and women. Women spend more time than their partners on household chores and taking care of their children, no matter how much they work outside the home' (Thorbecke, 2020). 


\section{Masako Ishii-Kuntz et al.}

While Japan and Norway are ranked very differently in WEF's 'Gender Gap Report,' aspects of the Norwegian labour market complicate this polarised picture of 'good' and 'bad' or 'pioneer' and 'backward' states in regard to gender equality. For example, the Norwegian labour market is highly gender-segregated along occupational lines (Reisel et al., 2019), and Norway is among the countries with the largest STEM gender gaps in education (Stoet and Geary, 2018). And, while Norway is considered to be a bastion of gender equality, it has a long history of ignoring its problems with domestic racism, including widespread social mistrust of non-Western immigrants, a bias it shares with Japan.

A few words on the definitions of gender and gender equality are in order. Certainly, feminist and queer theory, LGBTQ activism and legal innovations have complicated conventional notions of gender. However, many of the sources explored in this volume, from laws and public policies to the popular culture of TV comedies and advertisements, uphold a normative view of a cisgendered binary. Families tend to be defined as comprised of a male-identified father married to a female-identified mother, who typically raise two children. Nonetheless, our volume strives to include analysis of the experiences, legal challenges and resistances of those who do not conform to this binary.

This volume also shows how definitions of 'gender equality' have changed over time in Japan and Norway, both reinforcing and challenging historical beliefs, concerns for national identity and welfare, and individual human rights. The aim of this anthology is to understand how gender is intertwined in the dimensions of family and home, education, media, sexuality and reproduction by comparing these issues across the two countries. In doing so, we take an open approach to the notion of gender equality, noting the changes in its definition in the two contexts and exploring the ways in which gender equality has been inflected globally. This exploration aims to capture cross-cultural similarities and differences, with cultural meaning-making in focus. In this introductory chapter, we start by outlining this comparative approach before contextualising the overall study by looking at broad historical and sociodemographic dimensions around gender in both Japan and Norway. We conclude by introducing the individual chapters.

\section{Exploring gender equality in Japan and Norway: The challenges and opportunities of cross-cultural research}

This volume investigates the forms and contents of gender equality from a localised and historicised perspective, taking into account the concept's complexity and fluidity. Such an approach interrogates universalist assumptions and understandings of gender equality and assumes that gender intersects with other socially differentiating categories such as sexuality and socio-economic class (Cho et al., 2013; Davis, 2008; Manalansan, 2006; 
Purkayastha, 2012). Writing about the challenge that qualitative researchers face when attempting to reconcile complexity, detail and context, especially when undertaking cross-cultural research, Mangen refers to the crucial importance of 'reflexivity,' by which is meant 'the ability of researchers to take stock of their actions and their role in the research process' (Mangen, 1999, p. 110). Mangen deferring to Silverman's recommendations (1993) comments that when undertaking cross-cultural research, where attempts at 'wide contextualization' are often insufficient to provide adequate understanding of the phenomena being investigated, researchers should avoid being tempted by 'polar explanatory opposites' and be open to multifaceted analysis $(1999,110)$. In examining gender equality across Japan and Norway, we too strove to be open to comparative perspectives which did not pit both countries as polar opposites in terms of gender equality. Rather, we sought to remain open to the many paradoxes of equality and the challenges common to both countries, whether it comes to areas like work-home balance, restrictions on assisted reproductive technologies (ARTs) or the lived experience of trans people.

Salway et al. (2011) point to other potential challenges which crossnational comparative research brings into play including developing meaningful conceptual frameworks adapted to both contexts and avoiding generalised or essentialised categorisations within national contexts in the interest of synchronisation. They also caution against the tendency to produce analyses at the superficial level that reinforce independent country descriptions rather than generating integrated insights. Additionally, we need to remind ourselves that in some chapters due to the fact that the researchers and most of their interview participants, especially in Japan, were able to speak English, our interviewees had experiences of gender that may be distinct from the majority of those in Japan.

At the same time, Salway et al. (2011) assert that there are many ways in which cross-national comparative research can potentially strengthen the rigor and utility of research by researchers engaging in both ideological and methodological reflexivity. They also point to the potential of such research to raise awareness of the social and historical contingency of conceptual and methodological frameworks, as well as direct more attention to the need for research that has to take on board wider geopolitical contexts (Salway et al., 2011). Cross-national research also allows researchers to look at familiar data from new perspectives, questioning fixed groups and categories and engaging in analyses which take into account local, national and global impacts on specific phenomena (Salway et al., 2011). When employing such multi-layered analytical perspectives, cross-national research teams benefit from productive exchanges of ideas and experiences, which often result in conceptual and methodological innovation (Salway et al., 2011).

The starting point of this book occurred through such an exchange of ideas and experiences between two research teams. It is part of an ongoing collaborative project entitled Norway-Japan: Bridging Research and Education 


\section{Masako Ishii-Kuntz et al.}

in Gender Equality and Diversity, which is funded by the Research Council of Norway (2020). Most of the researchers contributing to this volume are affiliated either with the Center for Gender Studies of the Norwegian University of Science and Technology (NTNU, Trondheim) or the Institute for Gender Studies (IGS) at Ochanomizu University (Tokyo). These authors have a range of disciplinary backgrounds, including gender studies, sociology, anthropology and film studies. The collaboration has proved productive for several reasons. Namely, the project has increased awareness of the socially and historically embedded nature of gender equality, enhanced our appreciation of the need to take into account both localised perspectives within Japan and Norway as well as wider sociopolitical and geopolitical considerations, and, finally, drawn our attention to critical reflectivity in terms of our methodological choices.

As a result of the exchange of ideas across research teams, most of the chapters are co-authored by both Japanese and Norwegian researchers, while others have been authored by a researcher from one national context with feedback from researchers in the other context. The researchers engaged with a variety of data, including questionnaires, interviews, governmental documents, advertisements and films. We have used different comparative methods, including generating parallel data in both countries, comparing similar types of data (such as policy documents relating to similar thematic areas) and comparing cultural products which shared themes. For example, for Chapter 7 on women in academia, Norwegian researchers interviewed academics in both Japan and Norway on their career trajectories, using the same interview guide. While the research was mostly undertaken by researchers from Norway, Japanese colleagues helped with the recruitment of informants and interpretation of results. In Chapter 10 on trans experiences in Japan and Norway, another interviewbased chapter, the Norwegian interviews were conducted alone by the Norway-based author, while in Japan the two authors conducted the majority together.

In the chapters based on documentary or media analysis, language constraints necessitated that Japanese and Norwegian researchers worked on each data set separately. As Mangen (1999) notes, the linguistic dimension of cross-cultural research cannot be disengaged from the cultural context, nor from the specific way the discipline(s) involved have evolved within the national context. Chapter 12 on ARTs for example brought together two specialists in reproduction in both national contexts, who analysed policy and media documents in Japan and Norway, before identifying points of common concern and interest.

Finally, a couple of the chapters discuss cultural phenomena. In Chapter 8, two Norwegian researchers compared two historical comedies that parody modern men's working and domestic lives in Japan and Norway. A Japanese colleague assisted the authors in their study of the Japanese film by providing an English transcription of the script, details on the historical 
background, feedback on their interpretations of the films and wider knowledge on the generic antecedents of the Japanese filmic genres involved. Such collegial dialogues across all the chapters were crucial to engendering the new perspectives which cross-cultural research affords.

\section{Gender equality in Japan and Norway: A brief historical review}

The year 1970 marks the beginning of Norway's second wave feminist movement, as it was the year the Norwegian Association for Women's Rights organised its first large meeting in Oslo (Danielsen et al., 2013). In the following months, many women's groups formed across Norway, increasingly attracting media attention. These groups discussed various issues, including women's housing problems and labour force participation. Although the issues were diverse, the second wave feminism increased women's solidarity across different layers of the population by encouraging women to join forces to realise gender equality. Representing a different sensibility of women, these widespread movements marked a significant departure from the first wave feminism, which had had a limited impact on Norwegian society (Blom et al., 2005).

In 1970, a new women's liberation movement called 'Woman Lib' emerged in Japan from the New Left and radical student movements of the late 1960s. This movement was in sync with radical feminist movements in the United States and elsewhere. The activists forwarded a comprehensive critique of the maledominated nature of modern Japan, arguing for a fundamental change in the political-economic system and culture of the society. What distinguished them from previous feminist movements was their emphasis on the liberation of women's sexuality. They did not aim for equality with men, but rather focused on the fact that men should also be liberated from the oppressive aspects of a patriarchal and capitalist system. The Convention on the Elimination of All Forms of Discrimination Against Women adopted by the United Nations General Assembly in 1979 was ratified by the Japanese government in 1985 .

The brief overview of the history of feminism and the related movements reveals striking similarities between Norway and Japan. In both nations, though gender equality and women's rights were considered important agendas since the mid-19th century, women's suffrage was not introduced until the first half of the 20th century. Additionally, in both countries, it was the second wave feminism which fervently pushed for women's rights and gender equality. These similarities are especially noteworthy given the differences in the degree of gender equality in contemporary Norwegian and Japanese societies.

\section{Structure of the volume}

This book is organised according to contributions that address various dimensions of gender-related issues in Japan and Norway. It is divided into five parts, plus an introduction and a concluding chapter. Altogether, there 
are 14 chapters that focus on issues related to gender in Japan and Norway. These chapters all share the common theme of looking at gender issues from comparative perspectives.

Given that the home is perhaps where many of us initially encounter gender roles, PART I analyses how strongly notions of gender are embedded in Japanese and Norwegian domestic spheres. This is thematised in a review of the historical literature as well as in the chapters on contemporary domestic issues such as fathers' participation in childcare and housework. PART II analyses how gender is intertwined in education in both contexts by presenting a historical overview of the relationship between gender and education, home economics education, feminist educators' attitudes towards pedagogy and academic career trajectories of women. PART III covers gender as it is portrayed in films and advertisements. Specifically, the chapters engage with the framing of masculinities in Viking and Samurai comedy films, and in television advertisements' presentations of the balance between a newly emerging kind of work and home life during the COVID-19 in Norway and Japan. PART IV presents issues related to sexuality, fertility and assisted reproduction. In particular, it analyses the modes of political positioning of trans people, the meanings of fertility and family planning and the development of regulations concerning assisted reproduction technologies in Japan and Norway. In PART V, we present a dialogue between two senior feminist scholars in Japan and Norway, reflecting on their involvement with feminism from their coming of age to their arrival into academic posts, and to holding positions of academic leadership within gender studies.

This volume itself may be only a small step toward our goal of studying various dimensions of gender-related issues in Japan and Norway. Nonetheless, it is a significant departure from previous studies that examined gendered practices in everyday life in only one societal context or regional framework.

\section{Family and home}

In the chapter 'Gender and Home in Japan and Norway: Considering the Past and Contemplating the Future' (Ch. 2), Guro Korsnes Kristensen, Priscilla Ringrose and Masako Ishii-Kuntz address the gendered meanings typically ascribed to the home in the two national contexts. To explore this question, they conducted a review of a wide range of contemporary research publications and media in Japan and Norway. They also describe the history, changes/transitions and present situations concerning the home to show that gender and home are closely intertwined in both countries. In particular, they draw attention to the differing amounts of time fathers and mothers devote to housework and childcare, suggesting ways in which social campaigns and cultural mores have promoted equal participation as an ideal. 
Masako Ishii-Kuntz's 'Caring Masculinity: Fathers' Childcare in Japan and Norway' (Ch. 3) focuses on gender equality in the home as demonstrated by fathers' involvement in childcare and housework. Analysing various publicly available nationwide data on men and women's participation in domestic chores in both countries as well as web survey data collected in 2020, the author finds that Norwegian men are more likely to be involved in childcare compared to their Japanese counterparts. In both countries, however, it is also shown that mothers are likely to be the main provider of childcare. Reasons for these persistent gendered practices at home are discussed by taking into account similarities and differences with respect to cultural and sociodemographic characteristics in the two countries.

\section{Education}

Ryoko Kodama, in 'Education and Gender in Japan and Norway from Historical Perspective' (Ch. 4), describes historical research trends in gender and education in Japan and Norway. In Japan, although gender as analytical concept shaped research generally in the 1980s, its introduction to educational research specifically was delayed because of a myth that gender equality had already been realised in post-war Japanese education. The author analyses statistical data collected by the governments on education in the two countries to show the gender gap in university enrolment and major fields, teacher ratios in preschools to universities and their salaries. In 'Creating More Equal Partnerships: Home Economics Education and Gender Equality in Japan and Norway' (Ch. 5), Jennifer Branlat and Junko Sano present the history of Home Economics education in Japan and Norway. Based on its history as a segregated subject for girls and young women, they ask how the subject area in its current form contributes to reducing inequalities within the home and the role it has to play in. promoting a gender-equal society in the two countries. This chapter is based on qualitative interviews with teacher practitioners and university-level faculty in teacher training, as well as on analyses of teaching plans and curricular texts in both Japan and Norway.

Jennifer Branlat's contribution, 'Teaching with Feminist Values: A Dialogical Narrative Analysis of Gender Studies Educator Narratives' (Ch. 6), examines gender studies education in Japan and Norway, a topic on which little research exists in either country. To compare feminist educators' attitudes towards pedagogy, Branlat conducted in-depth interviews with professors in gender studies. She covered issues such as teachers' and students' motivation for working or learning in the gender studies field, uniqueness of and the challenges faced by the field, the relations of gender studies to broader society and the kinds of pedagogy needed for today's society against the gender backlash. Branlat also questions whether a theoretical framework grounded in feminist pedagogy can be used transnationally to tackle these questions. In 'Making it in Academia: A Study of 
Career Narratives of Men and Women Professors in Norway and Japan' (Ch. 7), Vivian Anette Lagesen, Guro Korsnes Kristensen, Siri Øyslebø Sørensen and Derek Matsuda examine the career narratives that emerged in their in-depth interviews with men and women professors in Norway and Japan to shed the light on the gendered dimensions of academia in the two countries.

\section{Media}

In 'Masculinity in Contemporary Viking and Samurai Comedies: "It's Not Really Me, That Fear-Based Leadership Style Stuff"' (Ch. 8), Jennifer Branlat and Priscilla Ringrose analyse two recent popular productions, the sitcom series Vikings/Vikingane (created by Jon Iver Helgaker and Jonas Torgersen, 2016) and the film Samurai Shifters/Hikkoshi Daimyo (directed by Isshin Inudô, written by Akihiro Dobashi, 2019) to illuminate crises of masculinity in Norwegian and Japanese popular culture. Both comedies serve to defamiliarise contemporary societal pressures on men by staging them in a past dominated by militaristic, hegemonic hierarchies. But whereas both comedies are concerned with the unattainable imperatives of modern 'caring,' 'sensitive' manhood, the Norwegian series focuses on its 'excesses' while the Japanese comedy more light-heartedly affirms its egalitarian values.

With Chihiro Wada and Roger A. Søraa's contribution, 'Work-Life Balance and Equality Observed through Advertising during the COVID-19 Pandemic in Japan and Norway' (Ch. 9), we move into one of the most recent and urgent situations surrounding gender equality, namely the gendered (re)distribution of domestic labour amidst the rise of home office. They investigate how advertisements geared to national audiences represent Japanese and Norwegian households' ways of dealing with the balance between a new kind of work and home life. Specifically, they examine how advertisements envision balancing working at home during the pandemic while accomplishing necessary housework and caregiving. The authors focus on the presentation of certain domestic tasks as gendered, analysing how gender intersects narratives about the balance between work and home in everyday life.

\section{Sexuality and reproduction}

Exploring gender equality from a different perspective, france rose hartline and Kei Ishimaru's chapter, 'The Struggle to Belong: Trans and GenderDiverse Experiences in Japan and Norway' (Ch. 10) compares the collected interview narratives of trans-identifying people from Norway and Japan. They analyse the individuals' modes of political positioning and experiential sense-making amidst the changing political climate of their respective countries. By comparing the two contexts for how trans people view 
institutional conditions for security and reshape their experiences in restitutive ways, the authors show how the globalising trans movement's ideologies are translating into practice in Norway and Japan.

In 'A Matter of Gender (In)Equality? Public Discourses on Declining Fertility Rates in Japan and Norway' (Ch. 11), Guro Korsnes Kristensen and Yukari Semba explore the meanings that are ascribed to fertility and family planning when these issues are discussed publicly in Japan and Norway, asking whether and how gender and nation are made relevant to these debates. This chapter is theoretically situated within the field of biopolitics and population control, and the data material consists of newspapers and other news media items in both Japan and Norway published between 2018 and 2021. The authors identify three issues inciting public fears concerning fertility and family planning in Norway - the low fertility rate among ethnic Norwegians, high fertility among the immigrants and the environmental problems associated with global population growth. They also discuss how the declining birth rate in Japan is attributed to delayed marriage by women and the concomitant rise in the maternal age at childbirth.

Merete Lie and Yukari Semba, in 'Assisted Reproduction with Donated Eggs and Sperm: A Comparison of Regulations on Assisted Reproduction in Norway and Japan' (Ch. 12), examine the development of Norwegian and Japanese regulations concerning assisted reproduction with donated gamete (eggs and sperm) within a feminist theoretical framework. Debates about reproduction imply explicit and implicit discussions of gender difference, sexuality, heteronormativity and the question of what constitutes a family - a field with marked differences but also similarities in the two countries. In both Japan and Norway, a clear divide has existed between the legality of sperm donation and the prohibition on egg donation. A radical change took place when both countries legalised egg donation from 2020/2021. Analysing data consisting of official government documents, announcements and reports from academic and professional groups, and information from newspapers and other news media on political debates, the authors explore the ways in which cultural notions of gender, gender difference and gender equality in the two countries have influenced the debates and resulted in the recent amendments of legal regulations and professional guidelines.

\section{Dialogue}

'Becoming a Feminist Academic in Japan and Norway: A Dialogue with Professors Masako Ishii-Kuntz and Agnes Bolsø' (Ch. 13), facilitated by feminist scholar Jennifer Branlat, breaks with the academic format of the previous chapters and offers a discussion between two senior academics regarding their personal views on feminism, academia and gender equality in Japan and Norway. In this dialogue, Agnes Bolsø and Masako IshiiKuntz reflect on their long academic careers, engaging in a thought- 
provoking conversation on what feminism has meant to them and how it has impacted their different life stages. Coming of age in the late 1960s and early 1970s in different national contexts, each was influenced by the second wave feminism. Taking up issues such as sexuality, class, nation and power relations, they describe how feminism has represented a transforming energy along their journeys.

\section{Conclusion}

In 'Comparative Perspectives on Gender Equality in Japan and Norway: Reflections and Lesson Learnt' (Ch. 14), the editors reflect on findings, convergences and divergences between the two national cultures which the book has brought to light, discuss theoretical and empirical lessons learned and make practical policy recommendations. Furthermore, they consider lessons learned about cross-national and interdisciplinary research in this highly politicised field.

\section{References}

Blom, I., Sogner, S. \& Hagemann, G. (2005). Med kjønnsperspektiv på norsk historie: fra vikingtid til 2000-arsskiftet [With a gender perspective on Norwegian history: from the Viking Age to the turn of the year 2000]. Cappelen akademisk forlag.

Cho, S., Crenshaw, K.W., \& McCall, L. (2013). Toward a field of intersectionality studies: Theory, applications, and praxis. Signs, 38(4), 785-810.

Danielsen, H., Larsen, E., \& Owesen, I. (2013). Norsk likestillingshistorie 18142013 [The history of Norwegian gender equality]. Fagbokforlaget.

Davis, K. (2008). Intersectionality as buzzword: A sociology of science perspective on what makes a feminist theory successful. Feminist Theory, 9(1), 67-85.

Gullikstad, B., Kristensen, G.K., \& Ringrose, P. (Eds.). (2016). Paid migrant domestic labour in a changing Europe: Questions of gender equality and citizenship. Palgrave Macmillan.

Manalansan, M.F. IV. (2006). Queer intersections: Sexuality and gender in migration studies. International Migration Review, 40(1), 224-249.

Mangen, S. (1999). Qualitative research methods in cross-national settings. International Journal of Social Research Methodology, 2(2), 109-124. https://doi.org/10.1080/ 136455799295087

Purkayastha, B. (2012). Intersectionality in a transnational world. Gender \& Society, 26(1), 55-66.

Reisel, L., Skorge, Ø.S. \& Uvaag, S. (2019). Kjønnsdelte utdannings- og yrkesvalg: En kunnskapsoppsummering [Gender-segregated choices in education and occupation]. ISF Report. https://samfunnsforskning.brage.unit.no/samfunnsforskning-xmlui/ handle/11250/2592572

Salway, S.M., Higginbottom, G., Reime, B., Bharj, K.K., Chowbey, P., Foster, C. \& O'Brien, B. (2011). Contributions and challenges of cross-national comparative research in migration, ethnicity and health: insights from a preliminary study of 
maternal health in Germany, Canada and the UK. BMC Public Health 11(514), 1-13. https://doi.org/10.1186/1471-2458-11-514

Silverman, D. (1993). Interpreting Qualitative Data: Methods for Analysing Talk, Text and Interaction. Sage.

Stoet G., \& Geary D.C. (2018). The gender-equality paradox in science, technology, engineering, and mathematics education. Psychological Science, 29(4), 581-593. https://doi.org/10.1177/0956797617741719

Thorbecke, C. (2020). Gender equality 'key factor' to pandemic recovery efforts: Norway PM. ABC News. https://abcnews.go.com/International/gender-equalitykey-factor-pandemic-recovery-efforts-norway/story?id=74148403

United Nations (2020). Human Development Reports 2020. [Report]. http:// hdr.undp.org/en/content/latest-human-development-index-ranking

World Economic Forum. (2021). The Gender Gap Report 2021. [Report]. http:// www3.weforum.org/docs/WEF_GGGR_2021.pdf 


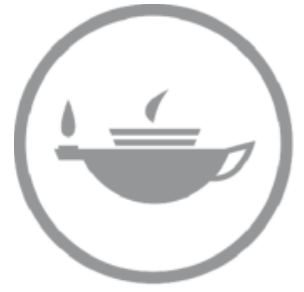

Taylor \& Francis Taylor \& Francis Group http://taylorandfrancis.com 
Part I

Family and home 


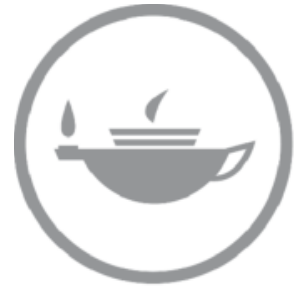

Taylor \& Francis Taylor \& Francis Group http://taylorandfrancis.com 


\title{
2 Gender and home in Japan and Norway: Considering the past and contemplating the future
}

\author{
Kristensen Guro Korsnes, \\ Ringrose Priscilla, and Ishii-Kuntz Masako
}

\section{What is a home and what does gender have to do with it?}

The aim of this chapter is to discuss and compare the ways in which gender and home are intertwined in Japan and Norway, exploring both their historic and contemporary contexts. Our overarching focus is the gendered meanings that have been and are presently ascribed to the home in Japan and Norway. We use our discussions of this meaning-making to reflect on what we can learn from national particularities and similarities across the two contexts in the light of today's globalised world, and to contemplate potential trends relating to the gendering of the private sphere.

In sociological and cultural research, the notion of home is often ascribed a straightforward empirical meaning. It is defined as a place of shelter, a space where people live, sleep, eat and provide or receive care. Importantly, the home enables people to withdraw from the outside world into a private sphere. In line with this, Carsten (2004) describes the home as a central place for the creation of family ties, given that relations of kinship often emerge 'through the intimate sharing of space, food, and nurturance' (p. 35). In most societies, the home is conflated with family, whether structured as a nuclear family or as an extended family combining several generations and/or many relatives (Carsten, 2004, p. 35). Moreover, the notion of the home often evokes a sense of attachment and belonging, in the sense that the expressions 'being at home' and 'feeling at home' connote being at peace and feeling comfortable (Moore, 1984). The home has also been described as a haven from the pressures of the outside world, as well as a site for leisure and recreation (Carsten, 2004).

At the same time, these rather idealised understandings of the home have been contested by other strands of research. These often examine the home as a potentially unsafe space for children, women, the elderly and others who are at particular risk of domestic violence. Similarly, scholars find that home may not signify stability or safety for migrants. In line with this, migration research points to the many millions of migrants who for various reasons have left their homes behind in exchange for more or less temporary residences in a new region, country or continent (Chatterjee, 
forthcoming 2022). Finally, another significant way of understanding the modern notion of home is to see it as a gendered realm, a private 'feminised' space strongly associated with the world of women. This stands in contrast to the 'masculinised' public sphere, more closely aligned to the domain of men (Erel, 2011; Lister, 2003; Pateman, 1989; Solheim, 1998).

Taking our inspiration from these general accounts of 'the home,' we 'home in' on the Norwegian and the Japanese contexts to ask: What gendered meanings are ascribed to the home in the two national contexts, both historically and today? What similarities and differences can we see? What are the most significant issues which emerge when gender is at stake?

\section{Research methods}

To explore these questions, we surveyed a wide range of social science and cultural studies research publications from Norway and Japan which engage with the concepts of home and gender in either Norway or Japan. These texts include both quantitative and qualitative studies and cover both historical and contemporary perspectives. Whereas the quantitative studies provide information about the statistical patterns relating to the Norwegian and Japanese home and domestic life, the qualitative studies provide insights into the cultural meanings that are attached to the Norwegian and Japanese home and to everyday life within the home historically and today.

We conducted online searches by using the search words 'home and gender' and 'gendered notions of the home' combined with 'Norway' or 'Japan' in standard academic search engines and databases. As homeowners living in and feeling a sense of belonging to Norwegian or Japanese homes ourselves, we also draw on our personal experiences and observations as insiders, whereas our position as outsiders to the other national context has helped us identify tacit knowledge which would otherwise not have found its way into the text.

As Irene Cieraad notes in At Home: An Anthropology of Domestic Space (1999), even though it is generally taken for granted that cultural conceptions of the home have some kind of national particularities, there are relatively few comparative studies in this field. In this chapter, we use comparison as an analytical tool to draw our attention towards similarities and variance. The overarching aim of the comparative perspective as we approach it is to reveal unique aspects of each national context that would be hard to detect otherwise (Mills et al., 2006).

\section{The Norwegian home}

Scholarship on the 'Western home' views it as a distinct entity, a social construct which has undergone dramatic changes as a result of the processes of 
modernity and the rise of capitalism. These forces have transformed the home from a site centred around the family as a self-sufficient production unit to a place where women are fulfilling their supposed 'natural mission' to clean, care and cook, and where men working outside the home can retreat (Lasch, 1977). This change created a new, highly gendered division between the private (home) as associated with women and the public (work) with men. Following this, a discourse emerged glorifying women's role in homemaking, and celebrating the home as her 'haven' (Solheim, 2007; Somerville, 1997).

\section{Home ownerships and trends}

The home is not only the cornerstone of the Norwegian way of life; it is a personal and highly adorned castle, where time and money are invested, and where life unfolds. (Brusdal, 2006, p. 35)

This statement about the Norwegian home echoes the perspectives of other researchers in both the Humanities and the Social Sciences, who present the home as a very important part of Norwegian life - on both practical and ideological levels (Gullestad, 1992; Solheim, 1998). Compared to many other national contexts, including European ones, home ownership is very common in Norway. Currently eight out of ten Norwegians are homeowners, and $98 \%$ can expect to own a home at some time in their lives. ${ }^{1}$ This trend has its roots in post-war national policies which explicitly aimed at creating a nation of homeowners.

The post-war home envisioned in Norwegian housing policies was popularly known as 'two rooms and a kitchen' - meaning a simple apartment with one living room, a bedroom, a bathroom and a kitchen for a couple and their two children to share. This meant that the whole family would often share one bedroom. In contemproary Norway houses and appartments are expensive (particularly in urban areas), and, as such, they usually represent a family's greatest investment and most important economic asset. Moreover, due to the steady rise in house prices over the last decades, housing has become an important market for investors. To buy a home in Norway, you must obtain mortgage approval from a bank before you can even start viewing houses or apartments. Property prices are determined as a result of a bidding process. This means that only those with inherited wealth, a very high income, or previous beneficial investments in the housing market can afford a detached home in an inner-city district.

High property values in urban Norway mean that many city dwellers to live in small homes, whereas rural residents typically enjoy much more spacious dwellings. In both urban and rural areas today, a large number of single occupant households exist. In 2020, 39\% of Norwegian households were single occupant households, and the average size of Norwegian households was 2,15 persons (Andersen, 2020). Whereas most Norwegians 
at some time in their adult life live with another person or their own children, multigenerational households are rare in Norway. In the case of student accommodation, however, the custom of cohabitating with peers is widespread. Even though Norwegians have relatively spacious homes, many also own a modest cottage ('hytte') in the mountains or holiday house by the coast. These cottages and holiday houses are used for weekend holiday breaks and function as second homes (Brusdal, 2006).

Another important aspect of the Norwegian home is the strong concurrence between the house and the family, and, more specifically in the 20th and 21st centuries, between the house and the nuclear family. According to the social anthropologist Marianne Gullestad, the most important function of the Norwegian home is to provide a setting for modern intimacy (Gullestad, 1993). As Gullestad formulates it, 'Norwegians do not only have houses, they have homes. The word hjem (home) brings together in one notion both the idea of a place and the idea of social togetherness associated with this place' (Gullestad, 1993, pp. 88-9). The home functions as the family's 'territory,' and the house is where its intimacy is played out (Gullestad, 1992). This conflation between family and home is also very much the case with the second homes (the cottage or the holiday house), as they are often handed over from one generation to the next, after years of overlapping use involving various cross-generational activities (Døving, 2020). Whereas children move out of the ordinary family home when they grow up, no one moves out of the cottage or holiday house. In this sense, the house, that is the first home, is more oriented towards the nuclear family, whereas the second home is more oriented towards the extended family (Døving, 2020).

At the same time, the Norwegian home is also a significant site for interaction with friends and sometimes even colleagues, both informally and for more organised parties and celebrations. Whereas pubs, parks, etc., are important meeting places in many other countries, in Norway the home is often the default setting for social activities beyond family ties. This means that the Norwegian home, especially the kitchen and living room, and everyday life in the home in these spaces is somewhat more public and also more on display than in many other countries. Following from this, the home is for many Norwegians a life project where identity is both constructed and communicated. According to Gullestad (1993), Norwegians 'use the home to create and express their specific ideas of identity and intimacy' (p. 89). Renovation and home decoration are important parts of this life project. Occupants' selection of colours, furniture and special consumer goods tell other people what kind of persons are living here (Brusdal, 2006). When it comes to interior aesthetics, a 'good' Norwegian home has traditionally been imagined as cosy, informal and warm (Brusdal, 2006; Gullestad, 1993, 2002; Lorentzen, 2008). In the past decades, this warm cosiness has in part been replaced by a more 'clean and functional' 'Scandinavian design,' as it is presented and sold in, for example, the Swedish furniture chain IKEA. 
The cosiness of the old times, as well as the more functional 'modern' style, have been and to a great extent still are the responsibility of women, who would typically be the ones hanging up the paintings on the wall and lighting the candles in the living room in the evenings, and it is women's identities which are most symbolically projected onto the interiors and style of the Norwegian home (Gullestad, 1984/2001). It is not surprising then that women consume far more home decoration magazines than men, in which they also figure much more predominantly as the lead consumer/ decorators. In line with this, women are more frequent consumers of furniture and other home decoration items than men. In times where gender equality is an ideal, men have, however, been increasingly entering the domestic arena. Still men tend to be more associated with the exterior housework, where they do more of the work, whereas women are still envisioned as the ones ruling inside (Kristensen, 2016). According to social anthropologist Runar Døving (2001), this association between women and the home has often been misinterpreted as some kind of oppression of women, yet quite a few women are enjoying their role in the home and find it to be a means of expression and creativity, using this position to exercise power in terms of making decisions regarding the family's social networks and daily routines. Examples of rather typical Norwegian homes are found in this photographs (Figures 2.1, 2.2, 2.3, 2.4, 2.5).

\section{The home in the housewife era and in times of gender equality}

Whereas Norwegian men have traditionally been responsible for the financial aspects of home ownership, as well as for maintenance work on the exteriors (and partly also interiors) of the home, as we have seen, women have traditionally been responsible for turning houses into homes. This was particularly true in the increasing affluence of the post-war era, when men, as the family's breadwinners, provided financially for the family while their wives spent their days taking care of their children and fulfilling their role as professional, though unpaid, housewives and home makers - cooking, cleaning and caring from morning till night (Danielsen et al., 2014). While the housewife era can be dated back to the 19th century with the establishment of the housewife schools, it is the 1950s which are most often described as the golden age of the housewife (Lorentzen, 2013).

Home décor, which in the 1950s and 1960s had become available and affordable for more families, was also an important part of this gendered work of turning houses into homes (Døving, 2001). The high standards women maintained in the home bore the vestigial influence of the Norwegian public housewife schools' training, which spread across Norway from the late 1800s to the mid-20th century (Avdem \& Melby, 1985; Hagemann \& Roll-Hansen, 2005). Their aim was to professionalise 


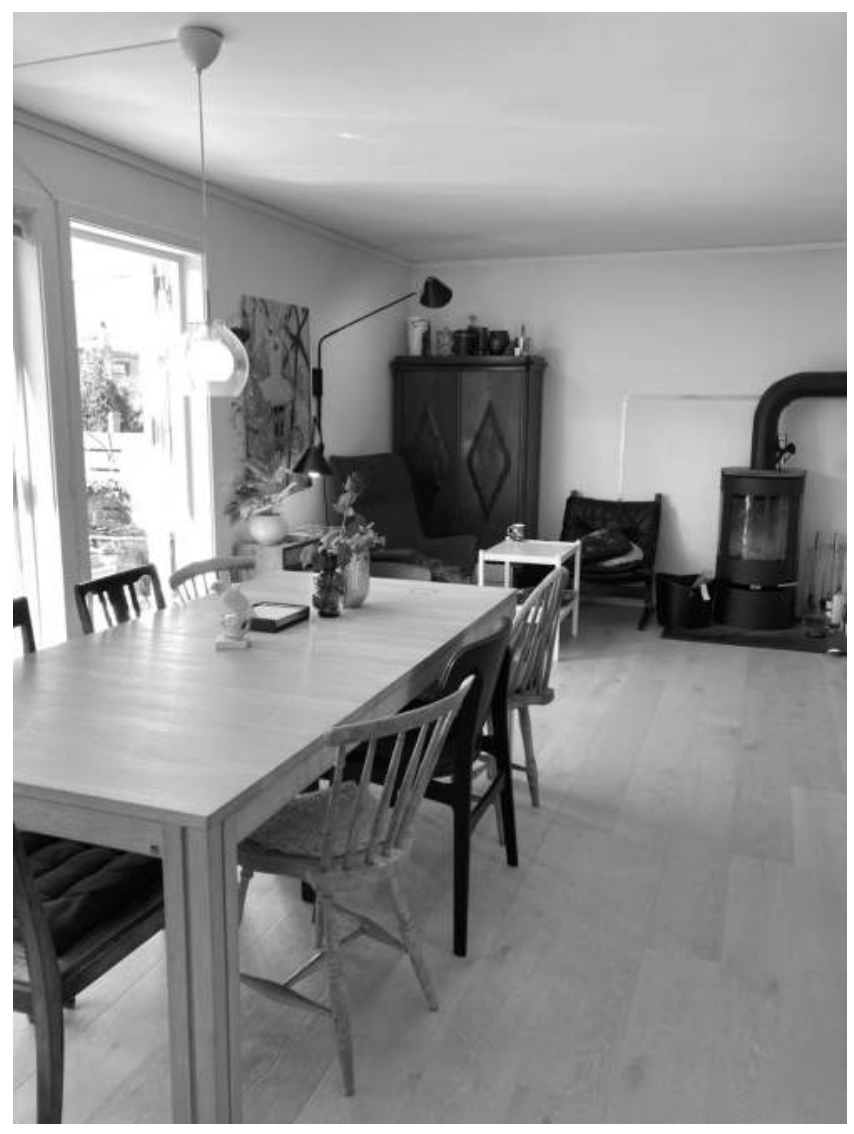

Figure 2.1 Norwegian living room; photograph by Guro Korsnes Kristensen.

'women's work' in the same way as the agricultural schools professionalised men's farm work (see Ch. 6 for more information). These schools created homemaking as a specialised arena which was reflected in the professionalised standards of housekeeping in private homes (Avdem \& Melby, 1985; Hagemann \& Roll-Hansen, 2005).

This traditional model was challenged in the 1970s by the feminist movement as Norway gradually transitioned to today's dual earner/dual carer model of gender equality, where both men and women work and care for their children (Danielsen et al., 2014; Ellingsæter \& Leira, 2006). As a result of women being more invested in paid work outside the home, the number of hours they currently spend on housework is low relative to previous decades, while on the other hand, men now take a more active role in housework and care work (Danielsen et al., 2014; Kitterød \& Lappegard, 2012). However, mothers of young children spend more time 


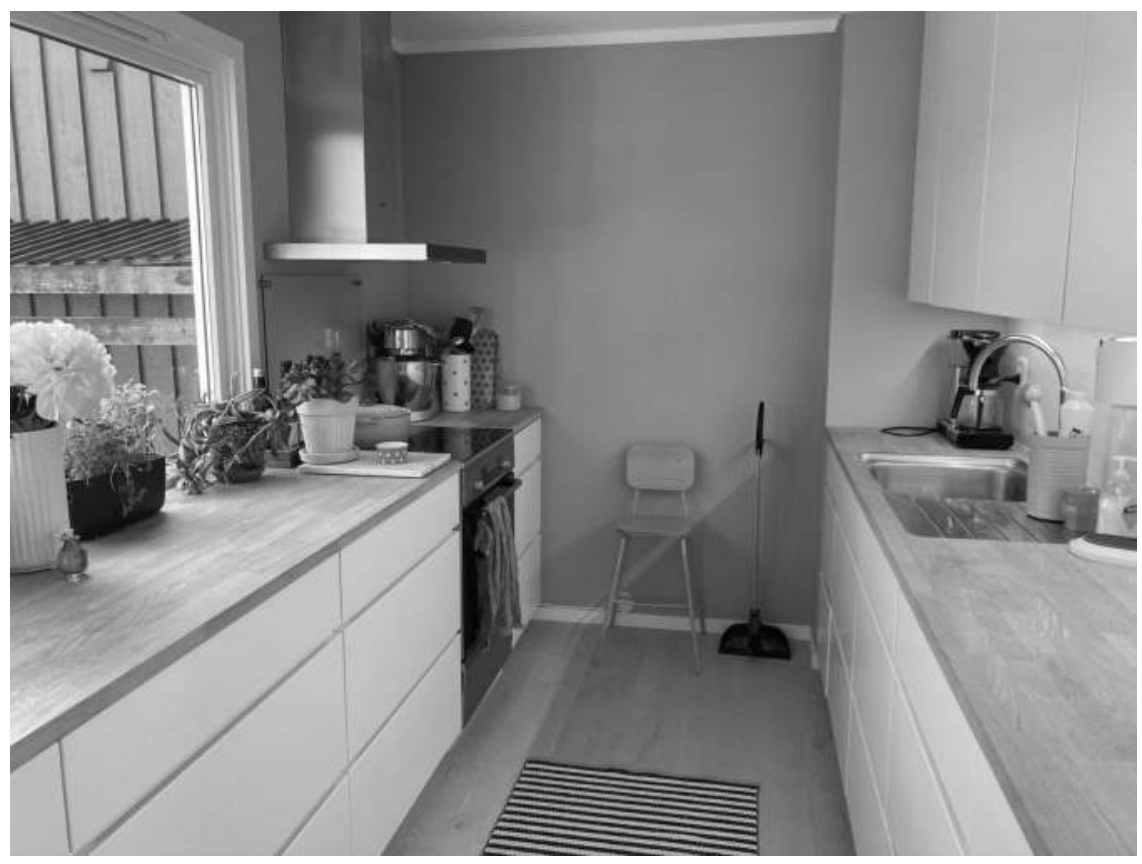

Figure 2.2 Norwegian kitchen; photograph by Guro Korsnes Kristensen.

on household work and less time on paid work than fathers of young children (Statistisk Sentralbyrå [SSB], 2018, p. 22). Having said this, gendered disparities during this stage of life have significantly reduced over the years, since fathers with young children spend more time on household work and less on paid work than previously, while the opposite is true for mothers. In 1980, the time that fathers spent on housework was $21 \%$ of that of the mothers, whereas in 2010, the proportion was 55\% (SSB, 2018, p. 23). For fathers, the time currently used on caring for the family amounts to $64 \%$ of the time spent by mothers, compared to $44 \%$ in 1980 (SSB, 2018 , p. 23). Whereas the post-war home was a site for women to 'do gender' in a traditional way, with clearly differentiated tasks and responsibilities for women and men, the dual earner/dual carer model for gender equality somehow transformed the home into a site for 'doing' gender equality.

\section{The modern Norwegian home - Gender equality as stress}

This new way of organising domestic tasks means that the actual doing of what Bridged Anderson (2000) once labelled the three Cs (cleaning, cooking and caring) in the home since the 1970s has become a way for 


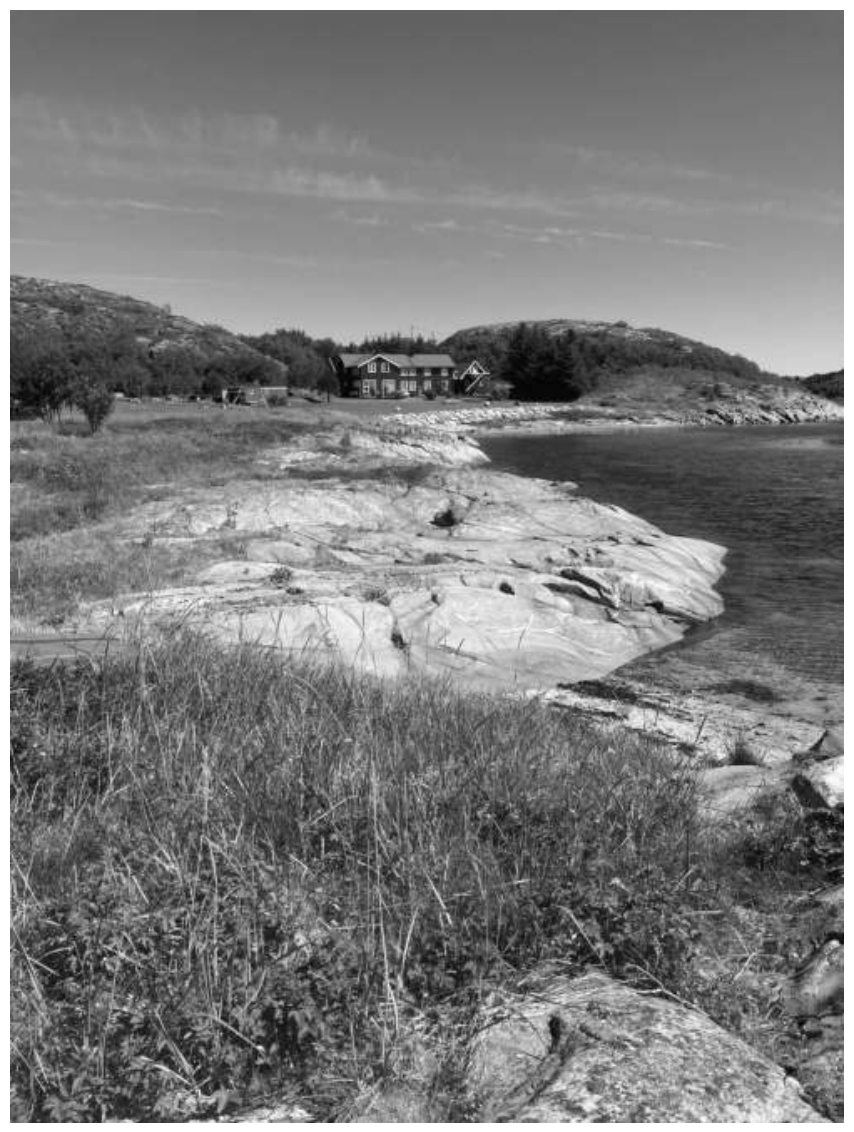

Figure 2.3 Traditional Norwegian house; photograph by Guro Korsnes Kristensen.

individuals and couples to become gender equal and to be seen as being gender equal. This means that the home is now considered the main domain where gender norms and gender equality ideals should be embraced, negotiated, and challenged (Døving, 2001; Klepp, 2006; Kristensen, 2017). According to sociologist Helene Aarseth (2011), Norwegian middle-class dual earner/dual carer couples who embrace the political and cultural ideal of gender equality turn all domestic tasks, including maintenance and construction work, into a self-realisation project where each member of the couple actively collaborates with the other in a 'gender-neutral' way. In line with this, Norwegian fathers' engagement in childcare is also seen as a typical expression of the Norwegian style of gender equality (Danielsen et al., 2014).

The other side of the coin is that the dual earner/dual carer model for gender equality has also turned the home into a site for arguments about 


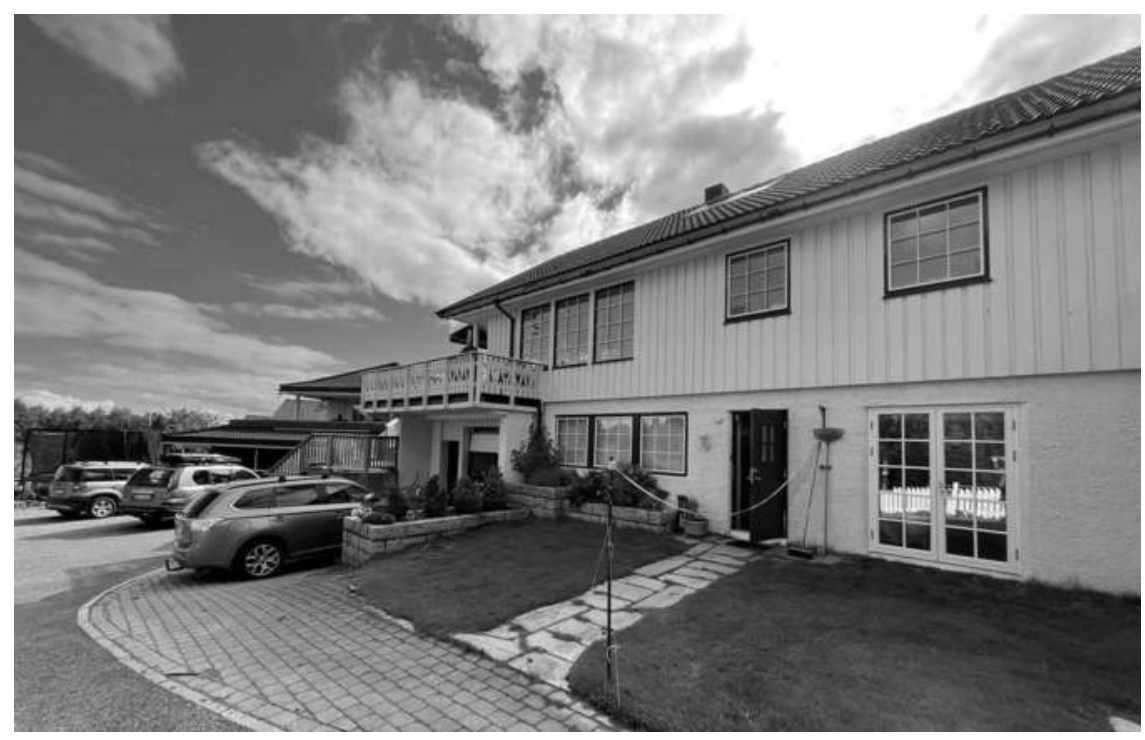

Figure 2.4 Norwegian house; photograph by Priscilla Ringrose.

domestic labour, and thus of the undoing of gender equality (Kristensen, 2016). Even though a lot of men have increased their efforts with cooking, cleaning and caring as more women have taken on paid work outside the home, this has not been enough to maintain the high standards of cleanliness carried over from the previous era's custom of female-dominated housework and home-making (Kristensen, 2016). Today, the combination of high cleaning standards and favourable economic circumstances mean that more and more Norwegians own an increasing number of 'things' and have an increasing amount of mess to be cleaned up in their increasingly spacious first homes, as well as in their second homes. And even though welfare state provisions for families have increased over this same period, this situation has been described as having led to a 'time-bind in relation to the home-work balance, in particular for families with young children (Kristensen, 2016; 2017).

For many Norwegian families, the time-bind - in part created by high standards for the cleanliness and style of their homes - is a pressing challenge which they attempt to solve in a variety of ways (Danielsen et al., 2014). One widespread solution which women opt for is to reduce their working hours (to continue) to take on the role of the primary homemaker (Kitterød \& Lappegård, 2012). Another solution to the time-bind is for couples to pay a third party to assist with domestic tasks. Compared to many other European countries, Norway does not have a history of hiring paid domestic labour. This was particularly true in the post-war era, when 


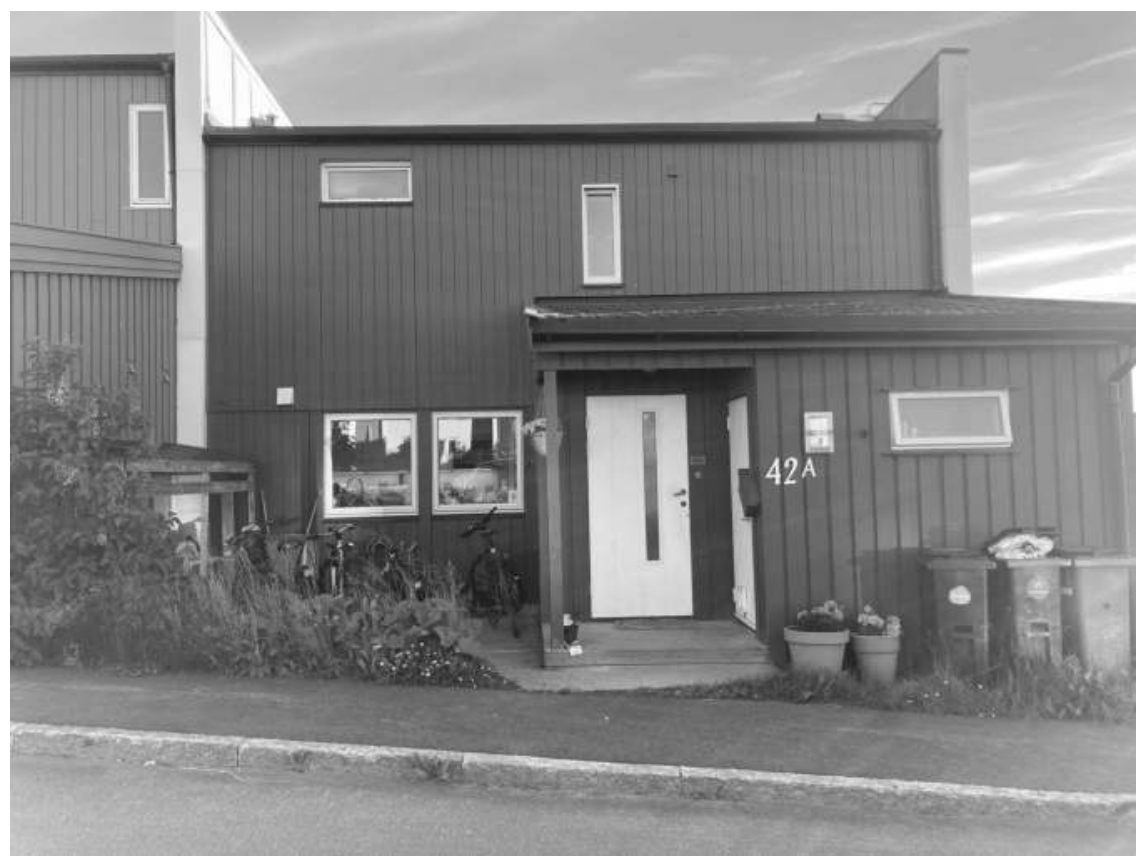

Figure 2.5 Norwegian house; photograph by Guro Korsnes Kristensen.

social democratic ideologies introduced a strong focus on public welfare and equality and when notions of social hierarchies and servitude were explicitly rejected (Sollund, 2010). In the last decades, however, this seems to have changed, as the employment of various kinds of domestic labourers has steadily grown in parallel to the growing pool of migrant labourers (Kristensen, 2016). The most common forms of paid domestic labour in contemporary Norway are in the areas of home cleaning and au pairing. Whereas the au pair arrangement, which in legal terms is regulated as cultural exchange and not work, is today most widely used by women from the Philippines (Utlendingsdirektoratet [UDI], 2020), the home cleaners are more often migrant women from Eastern Europe (Friberg \& Tyldum, 2007). Overall, au pairing is a much more marginal phenomenon in Norway than home cleaning, but it has nevertheless shown rapid growth in recent years (Kristensen, 2017).

These developments mean that more Norwegian families are outsourcing tasks that were traditionally labelled female but which today, in line with the dual earner/dual carer model of gender equality, are ideally expected to be shared between the couple. This also means that more and more families are employing an extra person who is not part of the family to help keep or take charge of keeping the house tidy and clean. Whereas this part-time 
employee helps keep the home clean and cosy even when the 'woman of the house' is out working, she also 'disturbs' the Norwegian home as the site of the nuclear family, and paradoxically she also represents a partial return to a time when the three Cs were not part of men's repertoire and when the home was a place for relaxation and not work.

\section{The Japanese home}

In the contemporary East Asian context, home usually means a place in which members coexist by providing essential physical and psychological care for each other. Historically, however, East Asian homes also functioned as a hierarchical unit based on age and gender. That is, elderly male members of the family controlled the household budget, and the eldest son and heir eventually assumed leadership from his father. In Japan, this patriarchal system, associated with the samurai class, is known as the ie system, which is also translated as 'household,' denoting both the physical home, the family members and the family lineage. Under this $i e$ system, the father was given absolute authority over individual family members in making all the important decisions, including the selection of an adult child's occupation and marriage partner. The Meiji Civil Code which went into effect in 1898) incorporated much of the ie system, retaining the power of the household head and making the family the basic unit of modern Japanese society; this Code remained in effect until the post-war reforms of the late 1940s.

Although such strictly patriarchal homes have largely disappeared in many contemporary East Asian countries, where partners have been ascribed equal status in the home, there still remains a strong emphasis on women's roles as mothers and homemakers and men's roles as breadwinners (Ishii-Kuntz, 1994; Smith \& Schooler, 1978) that can be traced to these traditional beliefs about the home. While the term 'good wife, wise mother' sounds outmoded, one still finds motherhood defined as women's primary mission in Japan.

In Japan, the home ownership rate was approximately $61.2 \%$ in 2018 , and has remained relatively unchanged since 2003 (Kettenhofen, 2021). Out of all the residential buildings in Japan, detached houses are the most popular, and the majority of ordinary Japanese households live in detached houses. The home ownership rate, however, varies considerably depending on the regions of residence. In larger metropolitan areas such as Tokyo, this rate is $45 \%$, whereas in rural Akita, a north western prefecture, home ownership is the highest for all of Japan at $77.3 \%$. Additionally, of the homeowners in the Tokyo area, $44.1 \%$ own condominiums rather than detached houses. The most popular floor plan of these urban condominiums is called 2LDK (2 rooms with a living+dining kitchen and a bedroom) and is similar to the small Norwegian urban family space. The smaller condominiums may reflect the fact that there are many more 


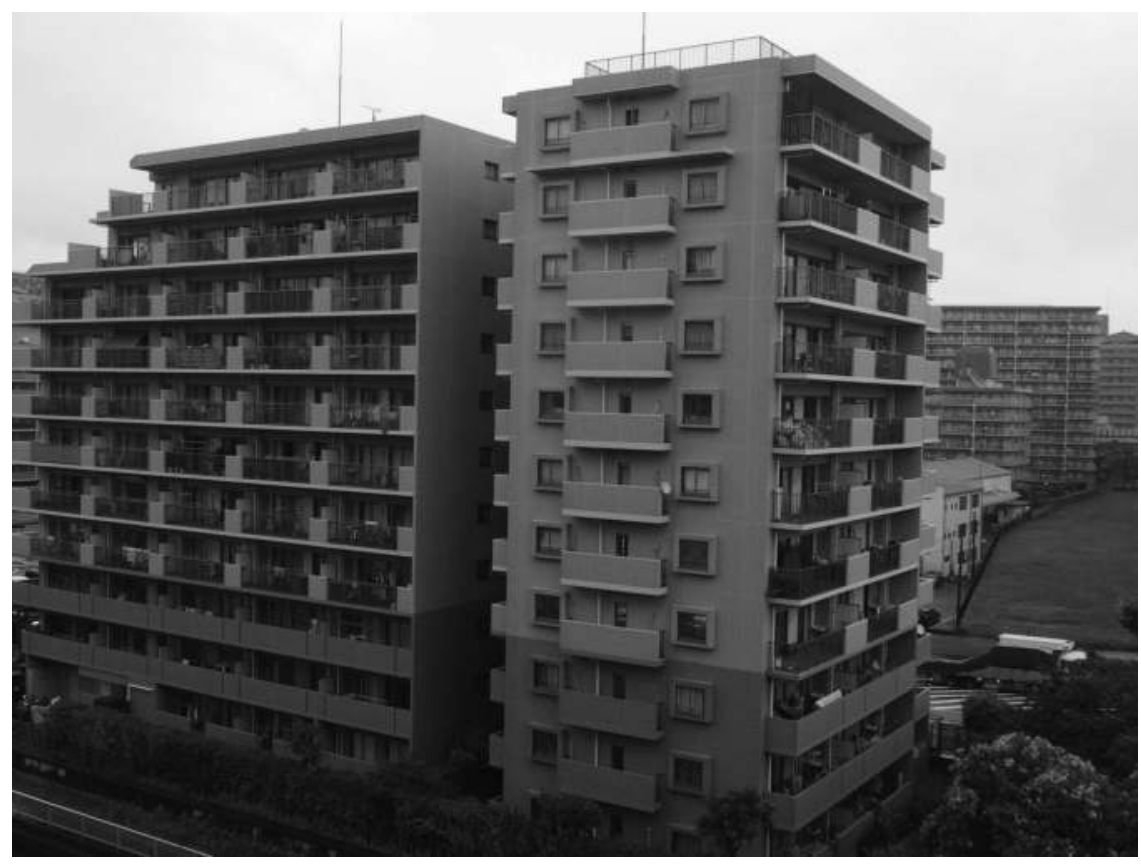

Figure 2.6 Japanese apartment buildings; photograph by Masako Ishii-Kuntz.

nuclear families living in larger cities and many more extended families living in smaller cities. Examples of typical Japanese homes in urban and rural areas are seen in the photographs (Figures 2.6, 2.7, 2.8, 2.9).

Home ownership has often been considered a dream for many Japanese as it symbolises the entry into true adulthood as well as long-term economic security. Also, as in Norway, home ownership represents a family's largest investment and most important financial asset. This trend seems particularly evident among Japanese men whose bread-winning responsibility is still considered their dominant role. Japanese homes, especially in less populated areas, are the places where family events such as birthdays and new year celebrations take place. This may not be the pattern in large cities because of the availability of many family restaurants and other gathering places as well as the relatively small sizes of homes. Other than these family events, large gatherings with relatives and friends are not common in Japanese homes. This can be explained by the clear division between public and private spheres in which home is considered the most private place to which even relatives and friends are not usually invited. As a result, Western type large gatherings which take place in private homes and gardens, such as barbeque parties, are very uncommon in Japan. Because of this public-private division, even co-workers and colleagues in Japanese workplaces may have no idea about each other's homes. 


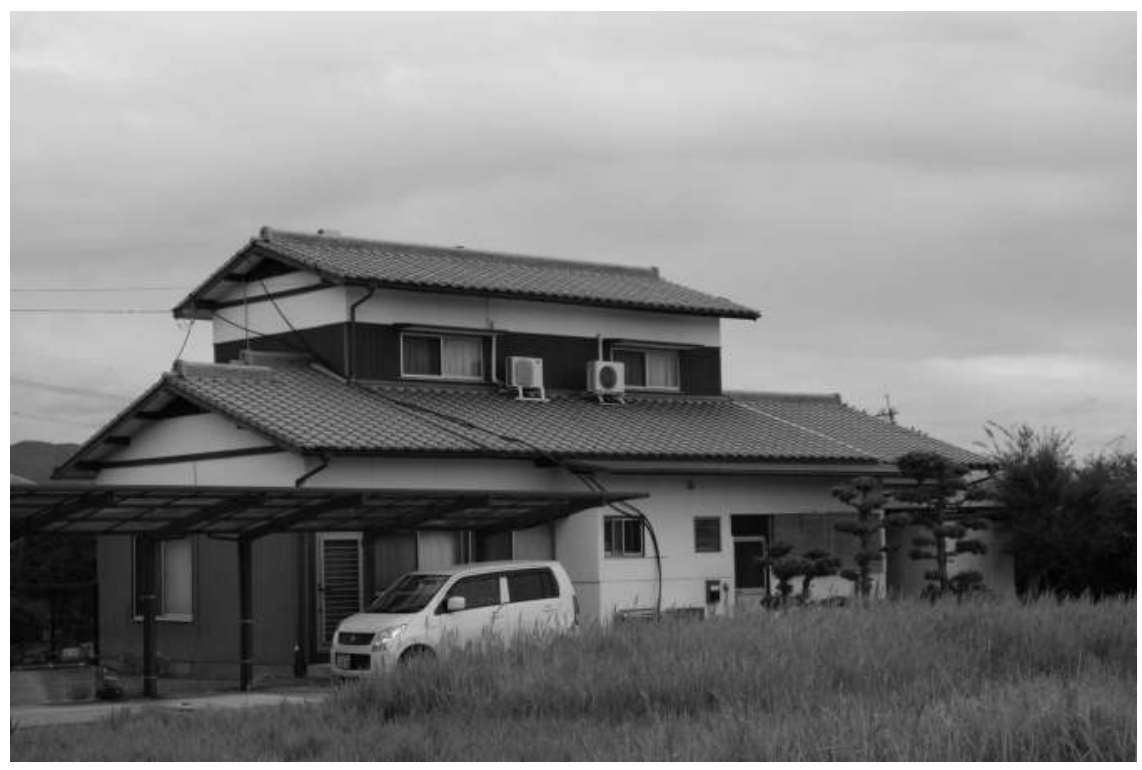

Figure 2.7 Japanese house; photograph by Juliette Ringrose.

In Japan, as in Norway, many magazines are devoted to homemaking and home décor that frame women as the main consumers/designers, and Japanese, too, struggle with an excess of things in their homes, a phenomenon that gave rise to the popularity of decluttering experts such as Marie Kondo.

Another recent trend regarding Japanese homes is the shut-in ( $h i k i$ komori) phenomenon. This issue refers to the population of young men, who are frequently eldest sons, that have shut themselves off from the world by retreating in their bedrooms. Although a small percentage of young women have become shut-ins, too, the issue is mainly associated with men; many of these men continue to keep up this social withdrawal even as they reach middle-age and their (financially supporting) parents become elderly.

\section{The historical Japanese home as a gendered institution}

Of all the social institutions in Japanese society, home is perhaps where gender inequality is most constantly displayed. According to the report of the Gender Equality Bureau Cabinet Office (2016), approximately 44.7\% and $37 \%$ of Japanese men and women, respectively, think that it is better for men to be breadwinners and women to be homemakers. Men's participation in childcare and housework is quite limited, with an average of 


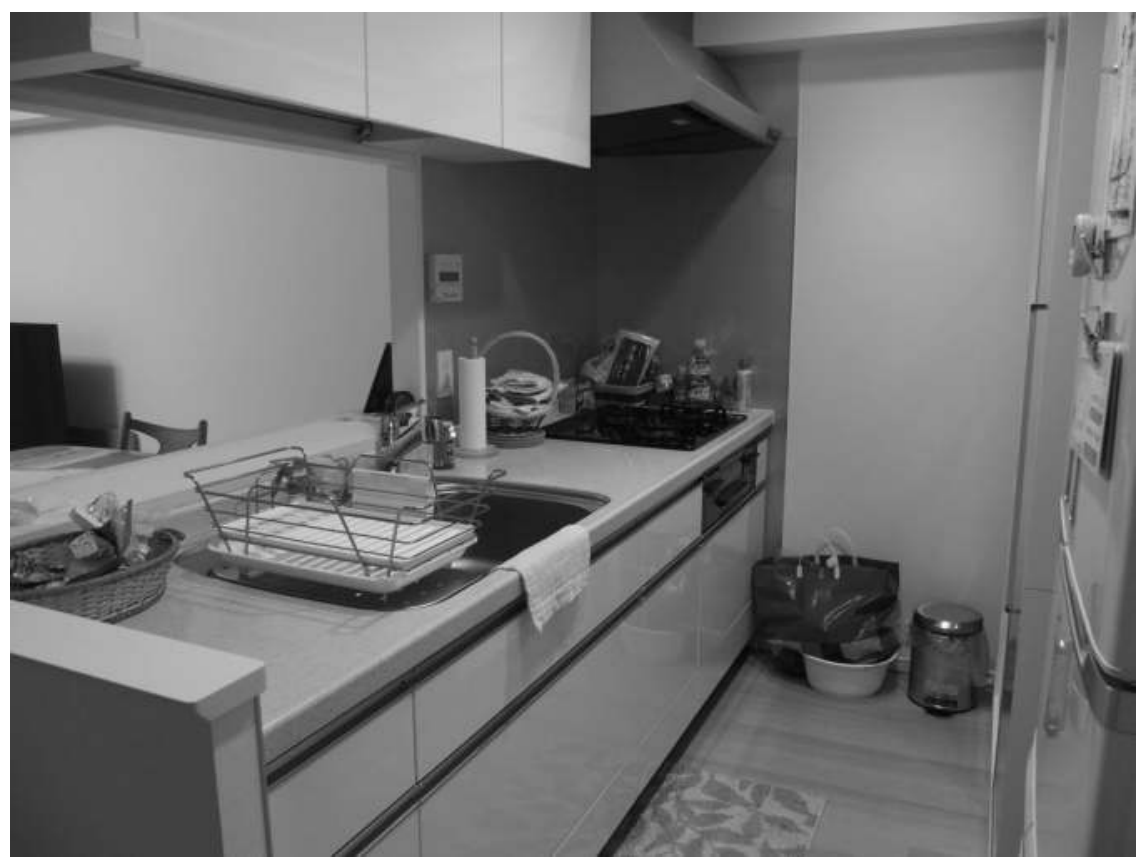

Figure 2.8 Japanese kitchen; photograph by Masako Ishii-Kuntz.

1.4 hours per day spent on these activities. This is considerably lower than the figure for women (7.6 hours). In addition, many Japanese believe in the so-called 'three-year-old myth,' which emphasises the critical role mothers play in their children's first three years of 'healthy' psychological development (e.g., Tama, 1985). Several studies in Japan also point out how traditional gender roles are learned at home with lasting impact on women's and men's educational and career choices (e.g., Sasahara, 2008). In the following, we will briefly present the historical antecedents of the modern-day gendered home.

The concept of 'home' first appeared in the 1880s during Japan's Meiji period, which marked the rise of women's homemaker roles (Muta, 1996). Within the aforementioned ie system, brides marrying into the family found themselves under the strict supervision of their mothers-in-law, felt pressure to produce male heirs and had few rights in divorce or to property. In common with other East Asian family models, the ie system upholds Confucian values of loyalty, which demand that family members show respect to the household head (Kitano, 1976). In the late 19th century, Japanese intellectuals coined the term 'good wife, wise mother,' blending Victorian notions of women's place in the Christian home with Confucian values of loyalty, to argue for women's education and their modern role in 


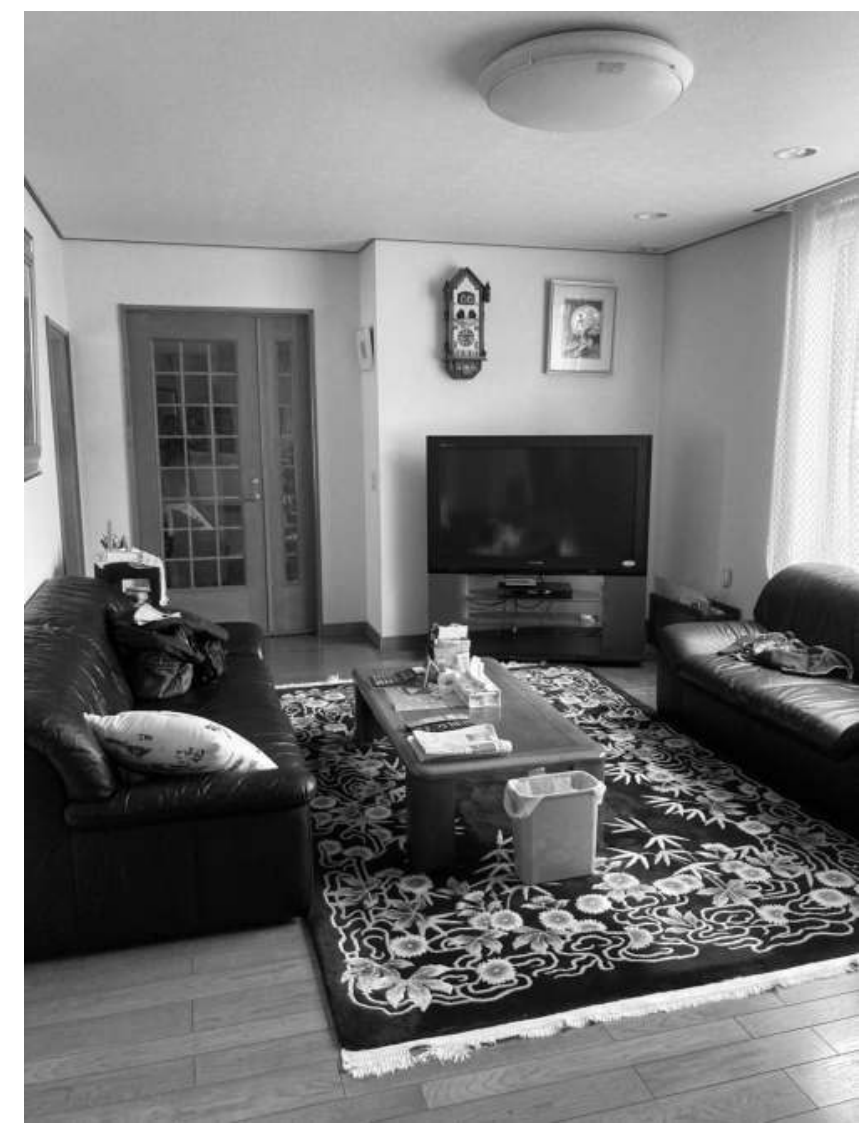

Figure 2.9 Japanese living room; photograph by Masako Ishii-Kuntz.

childrearing, domestic management and the creation of a patriotic, thrifty household.

In the succeeding eras, the gendered division of household labour came to be firmly accepted in Japanese families. This sharp division of women and men's roles at home continued during the post-war economic boom from the 1950s to the 1970s. During this period, Japanese salaried men were frequently called 'corporate warriors' who dedicated their lives to their companies. Many women, in contrast, became 'professional housewives' and kept themselves busy taking care of their husbands and children at home.

Since the 1980s and especially after the collapse of the bubble economy in the early 1990s, several incidents and demographic shifts necessitated three major changes in women and men's roles in Japanese homes. First, several shocking cases of child abuse and child killing by mothers were reported in 
the Japanese media in the 1980s, which consequently led to the collapse of the 'maternal instinct myth.' In addition, Makino (1982) found that mothers' isolated home environments and lack of husbands' childcare involvement increased levels of maternal stress and anxiety. These findings also contributed to the re-evaluation of home and family roles for many Japanese couples.

Second, Japan's birth rate began to decline in the late 1970s. The decline in fertility continues today, raising the government's concerns over the shortage of labour force in the near future. One 'solution' that the government has been promoting is to increase men's involvement at home assuming that paternal involvement would encourage their wives to have more babies. Several governmental campaigns to increase fathers' participation in childcare since 1999, for example, have contributed to raise awareness among Japanese people of the importance of paternal involvement (Ishii-Kuntz, 2013).

Third, there has been an increase in labour force participation among Japanese women, including those of childbearing age. According to the Labour Force Survey (Ministry of Internal Affairs and Communications. Statistics Japan, 2016), 57.1\% of women aged 25 to 44 were employed in 1986 , but this figure increased to $72.7 \%$ by 2016 . With this increase, many married women and men have found it necessary to reassign their roles at home.

\section{The modern Japanese home as a gendered space}

Despite several attempts to bring about equality in women and men's roles at home, we still see that these roles are sharply divided by gender. As a result, women are more likely than men to experience work-life conflict.

Encouraged by the Government's Act on Promotion of Women's Participation and Advancement in the Workplace fully enforced in 2016, an increasing number of Japanese women have been entering the labour force in recent years. However, many women find it rather difficult to realise their work-family balance mainly due to the shortage of day care centres as well as to the lack of support of their bosses and co-workers.

Despite the increasing conflicts that Japanese women are experiencing between work and family demands, outsourcing of childcare and housework is still uncommon in Japanese homes, unlike in Norway. Nagai (2016) reports an increase since the mid-1990s in terms of the costs of outsourcing cooking. However, the outsourcing of cooking includes purchasing ready-made foods at the supermarket and eating out at restaurants, but does not include the real labour of cooking in the home. Additionally, the cost of outsourcing housework constitutes only $0.03 \%$ of total household expenditures, which implies that for many Japanese homes, this not a common phenomenon. This may also be explained by the hesitancy that many Japanese express towards allowing 'outsiders' to enter their homes. 
In summary, with an increase of women's labour force participation, the sharing of familial roles at home has become a necessity in Japan. In reality, however, as discussed in chapter 3, men still work longer hours than do women, thus many fathers find it difficult to be involved in childcare and housework. Women, on the other hand, are burdened by an overwhelming amount of family and work demands. Unless there are major structural and attitudinal changes, gender equality at home may not be realised in Japanese society in the foreseeable future.

\section{The social meaning of the home: Similarities and differences}

In this chapter we asked: What gendered meanings are ascribed to the home in Norway and Japan, both historically and today, and what kind of similarities and differences can we see? What are the most significant issues which emerge when gender is at stake?

From the analysis, we have learnt that both Japan and Norway show a trend toward single household occupancy, with almost one-third of the households being single occupied. Also, in both countries, separate spheres for productivity for women (home) and men (work outside) have been celebrated in popular discourse, codified in law, instrumental in devising education plans, and naturalised through decades of practice. In Norway there were housewife schools which taught women to become proper homemakers, whereas in Japan, the 'good wife, wise mother' ideology of the late 19th to early 20th centuries served to educate women and imbue them with a mission. Even as domesticity no longer describes many Japanese women's lives, we can still see their influence in women's strong feelings about motherhood and the home as a venue of creativity.

In both cases, we note that the home is still a gendered sphere where women continue to be most responsible for housework and for childcare, although more recently there have been shifts towards men taking more responsibility, in both contexts. At the same time, the Norwegian dual earner/dual carer system and the parental leave system have gone a long way towards normalising fathers taking on childcare and spending more time on housework. This is helped by the relatively short working day for both men and women, which means that in principle both parents are at home from late afternoon. This stands in contrast with the long working hours expected in Japan, especially for men, which precludes many men from undertaking as much household and childcare duties, and which puts a relatively greater burden on working mothers.

Despite the contrast between Norway and Japan in terms of working hours, in Norway, there is still a lot of discussion about the 'time bind.' When addressing this time bind, it is taken for granted that somehow a couple should at least in principle be gender-equal when dealing with time stresses. At the same time this 'gender equality' is sometime achieved by 


\section{Guro Korsnes Kristensen et al.}

outsourcing domestic work to non-Norwegian women cleaners, paradoxically reinforcing the traditional feminised domestic sphere of the housework era of Norway. In Japan, recent debates have similarly reinforced that achieving a work-family balance is high on the public agenda, as campaigns for day-care facilities have shown.

The main difference between Norway and Japan is that in Japan a very strict distinction is maintained between the public and private spheres. Whereas the Japanese home is very much a private space where it is rare for 'outsiders' to the family to be invited, the Norwegian home is more likely to be a space where visitors are welcomed. Having said that, open hospitality is not as common in today's Norway as in, for example, Southern European countries, and immigrants report that they find Norwegian people generally reserved, and that they are very rarely invited into Norwegian homes (Penner, forthcoming). However, while Norwegian families can mitigate this pressure by outsourcing hourswork to (most often migrant and female) domestic labourers, this is not a possibility in Japan, given the tightly guarded domestic sphere and the greater reluctance to allow outsiders into the home.

Either way, gender relations are changing in both countries and the world is getting more international. Japanese homes are also decorated with furniture from IKEA, and Norwegian home owners are talking about Japanese minimalism and zen when discussing their home décor. It remains to be seen how global trends interacting with local customs and needs will shape the home and its potentially gendered identity in the future.

\section{Note}

1 Eiendom Norge. Den norske boligmodellen. https:/eiendomnorge.no/om-oss/ visjon-og-verdier/den-norske-boligmodellen

\section{References}

Aarseth, H. (2011). Moderne familieliv. Den likestilte familiens motivasjonsformer [Modern family life. The gender equal family's forms of motivation]. Cappelen Damm.

Act on Promotion of Women's Participation and Advancement in the Workplace (2016). Gender Equality Bureau Cabinet Office. Retrieved June 20, 2021, from https://www.gender.go.jp/english_contents/pr_act/pub/pamphlet/women-and-men $17 / \mathrm{pdf} / 2-5 . \mathrm{pdf}$

Anderson, B. (2000). Doing the dirty work? The global politics of domestic labour. Zed Books.

Andersen, E. (2020). Flere bor alene [More live alone]. Statistisk Sentralbyrå. [Report]. https://www.ssb.no/befolkning/artikler-og-publikasjoner/flere-bor-alene

Avdem, A.J., \& Melby, K. (1985). Oppe forst og sist $i$ seng: Husarbeid $i$ Norge fra 1850 til $i$ dag [First one up and last to bed: Housework in Norway from 1850 to today]. Universitetsforlaget. 
Brusdal, R. (2006). The Norwegian home-way of life, way of consuming. World Leisure Journal, 48(1), 34-39.

Carsten, J. (2004). After kinship. Cambridge University Press.

Chatterjee, A. (forthcoming 2022). Home away from home? Belonging and dislocation among migrant domestic worker. In S. Jha, \& P.K. Singh (Eds.), Home, Belonging and Memory in Migration: Leaving and Living. Routledge.

Cieraad, I. (1999). At home: An anthropology of domestic space. Syracuse University Press.

Danielsen, H., Larsen, E., \& Owesen, I.W. (2014). Norsk likestillingshistorie 18142013 [The history of Norway's gender equality 1814-2013]. Fagbokforlaget.

Døving, R. (2020). Det bilaterale slektskapets spenninger i prosjekt kjernefamilie. [Revisiting kitchen-table society: Bilateral tensions in the nuclear family]. Norsk antropologisktidsskrift, 1-2(31), 20-34.

Døving, R. (2001). Vaffelhjertets makt - Norske kvinners hushold [The power of the waffle heart: Norwegian women's household]. In E.D. Holm, \& S. Meyer (Eds.), Varene tar makten - makt og demokratiutredningen 1998-2003 [The goods are in power - the power and democracy investigation] (pp. 151-190). Gyldendal Norsk Forlag.

Ellingsæter, A.L., \& Leira, A. (Eds.) (2006). Politicising parenthood: Gender relations in welfare states. Policy Press.

Erel, U. (2011). Reframing migrant mothers as citizens. Citizenship Studies, 15(6), 695-709.

Friberg, J.H., \& Tyldum, G. (2007). Polania i Oslo. En studie av arbeids- og levekar blant polakker $i$ hovedstadsomrade [Polania in Oslo: An exploration of the working and living conditions among Polish people in Oslo.]. Fafo.

Gender Equality Bureau Cabinet Office. (2016). Heisei 29nen shakai seikatsu kihon chousa no kekka kara (Findings from 2016 Basic Survey on Social Life.) Retrieved June 20, 2021, from http://wwwa.cao.go.jp/wlb/government/top/hyouka/k_42/ pdf/s1-2.pdf

Gullestad, M. (1992). The art of social relations. Essays on culture, social action and everyday life in modern Norwayt. Scandinavian University Press.

Gullestad, M. (1993). Home decoration as popular culture. Constructing homes, genders and classes in Norway. In de Valle, T. (Eds.). Gendered Anthropology. Routledge.

Gullestad, M. (2001). Kitchen-table society. Universitetsforlaget. (Original work published in 1984).

Gullestad, M. (2002). Det norske sett med nye øyne. Kritisk analyse av norsk innvandringsdebatt. (New perspectives on 'Norwegian ways of being'. A critical analysis of Norwegian immigration debates). Universitetsforlaget.

Hagemann, G., \& Roll-Hansen, H. (2005). Housewives: Meanings and implications of unpaid work. Issues in contemporary history. Oslo Academic Press.

Ishii-Kuntz, M. (1994). The Japanese father: Work demands and family roles. In J.C. Hood (Ed.), Men, work and family (pp. 45-67). Sage.

Ishii-Kuntz, M. (2013). Sociology of child caring men. Mierva.

Kettenhofen, L. (2021). Rate of owned dwellings in Japan from 1973 to 2018. Statistica. [Report]. https://www.statista.com/statistics/1005428/home-ownership-rate-japan/

Kitano, H.H.L. (1976). Japanese Americans: The evolution of subculture. Prentice-Hall. 


\section{Guro Korsnes Kristensen et al.}

Kitterød, R., \& Lappegård, T. (2012). A typology of work-family arrangements among dual-earner couples in Norway. Family Relations, 61(4), 671-685.

Klepp, I.G. (2006). Skittentøyets kulturhistorie: Hvorfor kvinner vasker kloer [The cultural history of the dirty laundry. Why women are doing the laundry]. Novus.

Kristensen, G.K. (2016). Paid migrant domestic labour in gender-equal Norway: A win-win arrangement. In B. Gullikstad, G.K. Kristensen, P. Ringrose (Eds.). Paid migrant domestic labour in a changing Europe. Questions of gender equality and citizenship (pp. 169-193). Palgrave Macmillan.

Kristensen, G.K. (2017).'My home is my castle.' The Norwegian home in times of paid migrant domestic labour.' Culture and Organization 23 (4), 1-14.

Lasch, C. (1977). Haven in a heartless world: The family besieged. Basic Books.

Lister, R. (2003). Citizenship: Feminist perspectives. Palgrave.

Lorentzen, J. (2013). The History of Fatherhood in Norway, 1850-2012. Palgrave.

Lorentzen, A.G. (2008). Hjem kjore hjem. En empirisk studie av drømmen om det norske hjem [Home sweet home. An empirical exploration of the imagined Norwegian home] [Master's Thesis, University of Oslo].

Makino, K. (1982). Mothers of young children and their childcare anxiety. Journal of Family Education Research Institute, 3, 34-51.

Mills, M., van de Bunt, G.G., \& de Bruijn, J. (2006). Comparative research. Persistent problems and promising solutions. International Sociology, 21(5), 619-631.

Ministry of Internal Affairs and Communications. Statistics Japan (2016). Roudouryoku chousa nenpo (Annual report of the Labour force survey). Retrieved June 20, 2021, from https:/www.stat.go.jp/data/roudou/report/2016/ index.html

Moore, B. (1984). Privacy: Studies in social and cultural history. Sharpe.

Muta, K. (1996). Postwar family: Citizen and nation building in modern Japan and women. Shinyosha.

Nagai, K. (2016). Trends of outsourcing housework in Japan: Expenditures from household finances survey. Kikan Kakei Keizai, 109, 75-89.

Pateman, C. (1989). The disorder of women: Democracy, feminism and political theory. Stanford University Press.

Penner, A. (forthcoming). "How do you meet people here?" Exploring cosmopolitan hospitality in rural Norway. In Simonsen, J.K., Bottos, L.C. \& Chen, S. (eds.) Cosmopolitan networks.

Sasahara, M. (2008). An analysis of infant period gender-socialization processes, based on a survey of Shizuoka Prefecture High School Students. Studies in Informatics, Shizuoka University, 14, 33-59.

Smith, K.C., \& Schooler, C. (1978). Women as mothers in Japan: The effects of social structure and culture on values and behavior. Journal of Marriage and Family, 40(3), 613-620.

Solheim, J. (1998). Den åpne kroppen. Om kjønnssymbolikk i moderne kultur [The open body: On gendered symbols in modern culture]. Pax Forlag A/S.

Solheim, J. (2007). Kjonn og modernitet. (Gender and modernity). Pax Forlag A/S. Sollund, R. (2010). Regarding au pairs in the Norwegian welfare state. European Journal of Women's Studies, 143(17), 143-160. 
Somerville, P. (1997). The social construction of home. Journal of Architectural and Planning Research, 14(3), 226-245.

Statistisk Sentralbyrå. (2018). Women and men in Norway. [Report]. https:/www.ssb.no/ en/befolkning/artikler-og-publikasjoner/_attachment/347081?_ts=1632b8bcba0

Tama, Y. (1985). Creation of maternal instinct myth-Analysis of modern Western medicine and psychological analysis. Joseigaku Nenpo, 6, 16-25.

Utlendingsdirektoratet. (2020). Utdanningstillatelser etter statsborgerskap og type tillatelse (2020) [Permissions granted for education by citizenship and category of permission]. [Report]. https://www.udi.no/statistikk-og-analyse/statistikk/ utdanningstillatelser-etter-statsborgerskap-og-type-tillatelse-2020/ 


\title{
3 Caring masculinity: Fathers' childcare in Japan and Norway
}

\author{
Masako Ishii-Kuntz
}

\section{Fatherhood: A brief history}

This chapter examines fathers' involvement in childcare in Japan and Norway since the 1990s, a pivotal decade marked by major policy changes in parental leave that have had far-reaching consequences. After reviewing the major policies enacted from the 1990s to the present, we will examine how they may have affected fathers' involvement in childcare by reviewing publicly available statistics relating to parental leave. Second, looking closer at what factors may be related to the levels of fathers' childcare participation, we consider a range of social and ideological factors predicting paternal involvement. We will do this by constructing and examining a model by a multi-sample structural equation analysis. In particular, this model looks at how intersectional dimensions, such as employment status, education and age, predict men's gender ideology, which, in turn, influences men's childcare involvement. What insights does the model provide into explaining the extent of fathers' childcare within and across both national contexts? How are some factors differentially affecting fathers' childcare involvement in both countries? These are some of the questions to be addressed by the statistical analyses of the data collected in Japan and Norway in 2020 .

The historical review of modern Norwegian fatherhood is typically divided into three main periods in which notable changes in the position of fatherhood occurred (Lorentzen, 2013). The first period of 1850-1927 is represented by fathers in farming business. During this period of premodernisation, the sharing of work and household responsibilities between mothers and fathers was common (Lorentzen, 2013). A shift to industrialisation and urbanisation in 1927-1970, however, positioned fathers as the main economic providers. In the third period of 1970-2012, fathers again became very involved in childcare. This coincides with 'women's entry into the workplace, women's demand for equality' (Lorentzen, 2013, p. 110) which may have contributed to the collapse of the gendered division of household labour. In 1985, a national Commission on the Role of Men was formed to discuss the subject of men and gender equality. In 1991, the

DOI: $10.4324 / 9781003185222-3$ 
Commission issued its final report entitled 'Men and Care' which emphasised, among other things, the importance of mothers and fathers having equal entitlement to parental leave. It recommended instituting a 'father's quota,' whereby fathers would receive four-weeks paid parental leave, and if they did not take this leave, they would lose that much childcare leave time. The Commission gave three reasons for recommending the father's quota: The need to ensure equality between fathers and mothers, fathers' needs to care for their children and the children's needs for more contact with their fathers. In 1993, the father's quota was formally established in the new national parental leave policy.

In Japan, too, industrialisation and urbanisation affected the role of fathers. Although a few studies report that Japanese fathers were involved in educating and disciplining their sons in Edo period (1603-1868) (Ohta, 1994), childrearing became naturalised as the primary task of mothers throughout the Industrialisation Era. As in Norway, urbanised post-war Japanese society positioned fathers as breadwinners outside the home and mothers as primary caregivers within the home. It was not until the 1990s that the Japanese began paying more attention to fathers' roles and diverse types of fatherhood (Ishii-Kuntz, 2013). This increasing attention can be attributed to the so-called ' 1.57 (fertility) shock' of 1989, which marked the beginning of governmental efforts to establish family-friendly laws and policies, including campaigns for increased paternal involvement, to boost the nation's birth rate. The diversity of views about fatherhood was also debated in the 1990s. On the one hand, conservative critics advocated for the strong presence of fathers as authoritarian figures, as Hayashi (1996) wrote in his book Fusei no Fukken (Restoration of Paternity). On the other hand, several books about involved fathers were written by men who took childcare leave, and who went on daily one-hour 'strikes' to take their children to day-care centres (Otoko mo onna mo ikuji jikan o renrakukai, 1995; Tajiri, 1990). A confluence of factors contributed to the increasing attention to fatherhood in the 1990s: The decline in fertility and the subsequent government campaigns promoting paternal involvement, fatherhood research in developmental psychology, the introduction of men and masculinity studies to Japanese academia and general public, research on mothers' childcare stress and anxiety in family sociology, and the emergence of men's and fatherhood movements.

\section{Parental leave policy}

\section{Norway: The father's quota}

Today, Norwegian family policy is widely known for its generosity and for its significant role in supporting both high female labour-force participation and men's involvement in childcare. Although the state provision for childcare remained incomplete well into the 1980s, the introduction of the 
father's quota in the 1993 parental leave policy certainly enhanced Norway's journey to gender equality in the area of domestic chores.

Essentially, the father's quota system gave Norwegian fathers four weeks of 'use-it-or-lose-it' parental leave. Before the introduction of this system, only about $3 \%$ of men took paternity leave. Initially, Norway's rationale for establishing fathers' childcare leave and the quota system was to promote gender equality, a response to the agenda taken up by the strong women's movement in the beginning of the 1990s. Scholars such as Sainsbury (1996) would suggest that the paternity leave can be seen as breaking the male breadwinner model as well as granting father's individual right, but the parental leave and the quota system in Norway are not exactly based on an ideology of individual rights.

Despite the ideological battle over gender equality and individual rights discourse surrounding the father's quota over the last two decades, the research analysing the effects of paternity leave in Norway has focused mainly on the father-child relationship. Stated another way, today, the discussion of the father's quota is less about ensuring gender equality in the home, and more about the importance of father-child bonding. This research underscores the benefits to children and society when men participate more equally in caregiving work. Brandth and Kvande (2003), for example, described this shift in views of paternal involvement as moving away from gender equality discourse to celebrations of the nurturing fathers' positive effects on children.

Although Norway was the first country to introduce the father's quota in 1993, Sweden followed suit with a 'daddy month' in 1994. However, in both Norway and Sweden, further expansions of the father's quotas have been rather slow to occur. In fact, it has taken more than two decades to achieve quotas of about three months in both countries. Additionally, the Norwegian's father's quota policy has been contested by both the political left and right (Ellingsæter, 2020). These disagreements from both sides are perhaps due to the fact that the father's quota limits parental choice and punishes parents who do not use it.

While the 1993 quota rapidly increased fathers' use of the leave, few fathers took more than the four weeks, allowing mothers to take most of the shareable part of the leave. With the pressure to increase the father's quota, the government initiated the first extension, which led to the addition of one week to the total leave in 2005. Since 2005, the total parental leave has been extended from 42 to 49 weeks with $100 \%$ compensation from the workplace. In a move that recognised the importance of father's involvement in parenting, three weeks were transferred from the sharable part of the leave to the father's quota. Reverberations from the global financial crisis of 2008, however, changed attitudes toward the father's quota dramatically. In 2010, the Conservative Party joined the Progress Party in its goal to abandon the father's quota altogether. Although these parties 
worked to abolish the quota, the Christian Democratic Party and the Liberal Party later negotiated a compromise that allowed the quota to remain, but reduced it. As a result, in 2014 the quota dwindled from 14 to 10 weeks.

In 2017 , a parliamentary majority was in favour of reversing the cut to the father's quota in an effort to give children more time to spend with their fathers and to contribute to gender equality in the workplace (Ellingsæter, 2020). This majority successfully requested the re-elected minority rightwing government to present a bill restoring the father quota to the previous 14 weeks. Under Norway's current policy, effective as of July 2018, mothers get 15 weeks of non-transferable leave, plus three weeks before birth. It once again became popular for fathers to take parental leave. The importance of the parental leave system, including a special quota for fathers, is regarded positively today. Research has shown how a statutory, earmarked and non-transferable leave has impacted on the high use of the leave by Norwegian fathers (Brandth \& Kvande, 2020). This may mean that men's use of parental leave may be due to the nature of the way the leave is structured rather than the benefits to fathers and children.

\section{Japan: Revisions in parental leave policy}

In 1999, the Basic Act for Gender-Equal Society was enacted by the Japanese government. This Act includes the basic principles to form a gender-equal society and lays out the respective duties of the state, local governments and citizens. Additionally, it clearly states that both women and men are equal participants in labour force and family care. In 2000, the second phase of Basic Plan for a Gender-Equal Society was released to further promote gender equality in Japan. Then the third phase emphasised the importance of changing men's lives with an emphasis on reducing their long work hours and increasing their childcare involvement. In the fourth phase, however, plans directly related to men's involvement in childcare and elder care seem to have been significantly reduced perhaps due to a more conservative turn with the ruling Liberal Democratic Party in the Japanese Parliament. This pattern continued in the most recent fifth phase of the plan which was released in December 2020.

Much of the impetus for promoting men's caregiving comes from the ongoing crisis of Japan's low fertility rate. The Japanese government, with the assumption that the husbands' participation in childcare would encourage women to have more babies, revised the Childcare Leave Law in 1992 allowing fathers, for the first time, to take parental leave from work. However, there was no state compensation stipulated for such leave as it has been in Norway. It was not until one year later, in 1993, that Norway introduced the fathers' quota system, although the parental leave where fathers were allowed to share leave time with the mothers had been 
introduced in Norway in 1977. Japanese fathers' use of the parental leave was considered not only 'progressive' at the time but it was also seen difficult to actually use it due to the lack of financial compensation and health insurance coverage during the leave as well as harassment by and lack of understanding from their supervisors and co-workers (Ishii-Kuntz, 2013).

In 2010, the following three major categories were added to the Child Care and Family Care Leave Law:

1 Men whose wives are full-time homemakers can take the parental leave. (Prior to this, only men whose wives were employed could use the leave.)

2 If fathers take the first parental leave during their wives' maternity leave, they can take the leave again after the maternity leave ends. (Prior to this, men could take the leave only once during the 12-months after the birth of the baby but now they can take two leaves of equal or different duration.)

3 If both fathers and mothers use parental leave, then they can extend the leave up to 14 months. This is called 'Papa Mama Childcare Plus.' (Prior to this, either the father or mother could only take up to 12 months parental leave. If fathers take the leave, then the entire parental leave can be extended to 14 months.)

Although Japan and Norway have both been promoting fathers' childcare for the past several decades, there has been a gap in the proportion of Norwegian and Japanese men taking up such a leave. The report prepared by the Japan Institute for Labour Policy and Training (2017) shows that close to $90 \%$ of Norwegian fathers today take childcare leave. Although it has been almost 30 years since the 1992 revision of the Child Care Leave Law in Japan, which allowed men to take the parental leave, the proportion of Japanese men taking advantage of such a leave remains quite low at about only $7 \%$ in 2021 .

Figure 3.1 shows the changes in women and men in Japan taking childcare leave from work between 2007 and 2019. The percentages of women taking childcare leave fluctuate between 81.5 and 87.8. In contrast, only a small proportion of Japanese men take such a leave, although the percentages increased from 1.38 in 2010 to 7.48 in 2019. Similar gender differences are also noted with respect to the length of childcare leave between mothers and fathers. As shown in Figure 3.2, 31.1\% of women take 10-12 months leave, whereas the majority of men $(56.9 \%)$ are taking a leave of less than five days, despite the Papa Mama Childcare Plus initiative.

\section{Norway and Japan: Moving closer?}

Is Japan's family policy moving closer to the Nordic model of childcare schemes? Japanese lawmakers often praise the Norwegian model of 


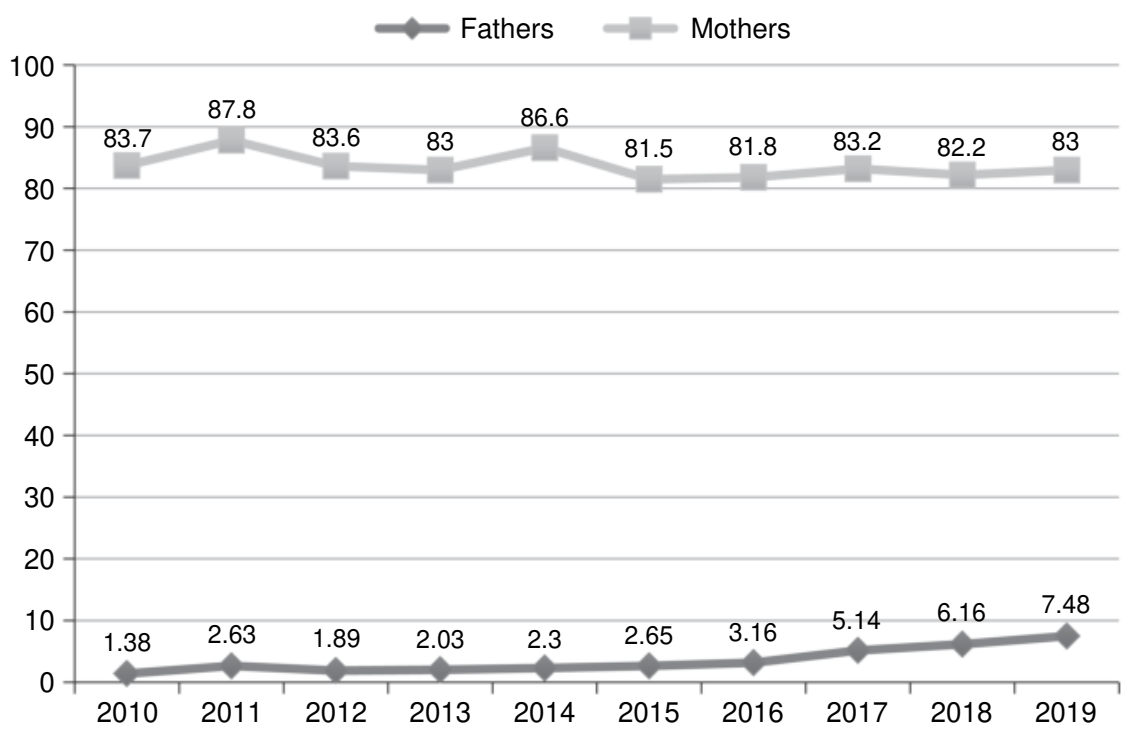

Figure 3.1 Percentage of mothers and fathers taking parental leave in Japan, 2010-2020.

Source: Adapted from Ministry of Health, Labour and Welfare, 2020, figure compiled by the author.

parental leave policy. In fact, the topic of father's quota in parental leave policy has been debated in the Japanese political arena. Atoh and Akachi (2005) suggested that there may be a possibility that Nordic family policy measures such as the father's quota could have an equalising effect on gender relations and hence result in better work-family harmonisation in Japan.

Japanese family policy has ostensibly moved closer to the Norwegian model over the 1990s and early 2000s. However, regardless of Japan's admiration of the parental leave policy in Norway, the relevant services are hardly guaranteed to all Japanese as a matter of right since only full-time regular employees are eligible for parental leave, whereas in Norway, parttime workers are also eligible to take the leave. Also, Toivonen (2007) argued that the Japanese childcare and parental leave schemes are weak in terms of continuity when compared to Nordic equivalents. While the new parental leave scheme of 2010 such as Papa and Mama Childcare Plus resembles the fathers' quota system on surface, the stringent eligibility conditions together with women's weak labour market position reduce this similarity in practice. For the latter, it is the gendered wage gap that makes it difficult for men to take up the leave because it means a large income loss in the family. Furthermore, regarding the context for the development of 


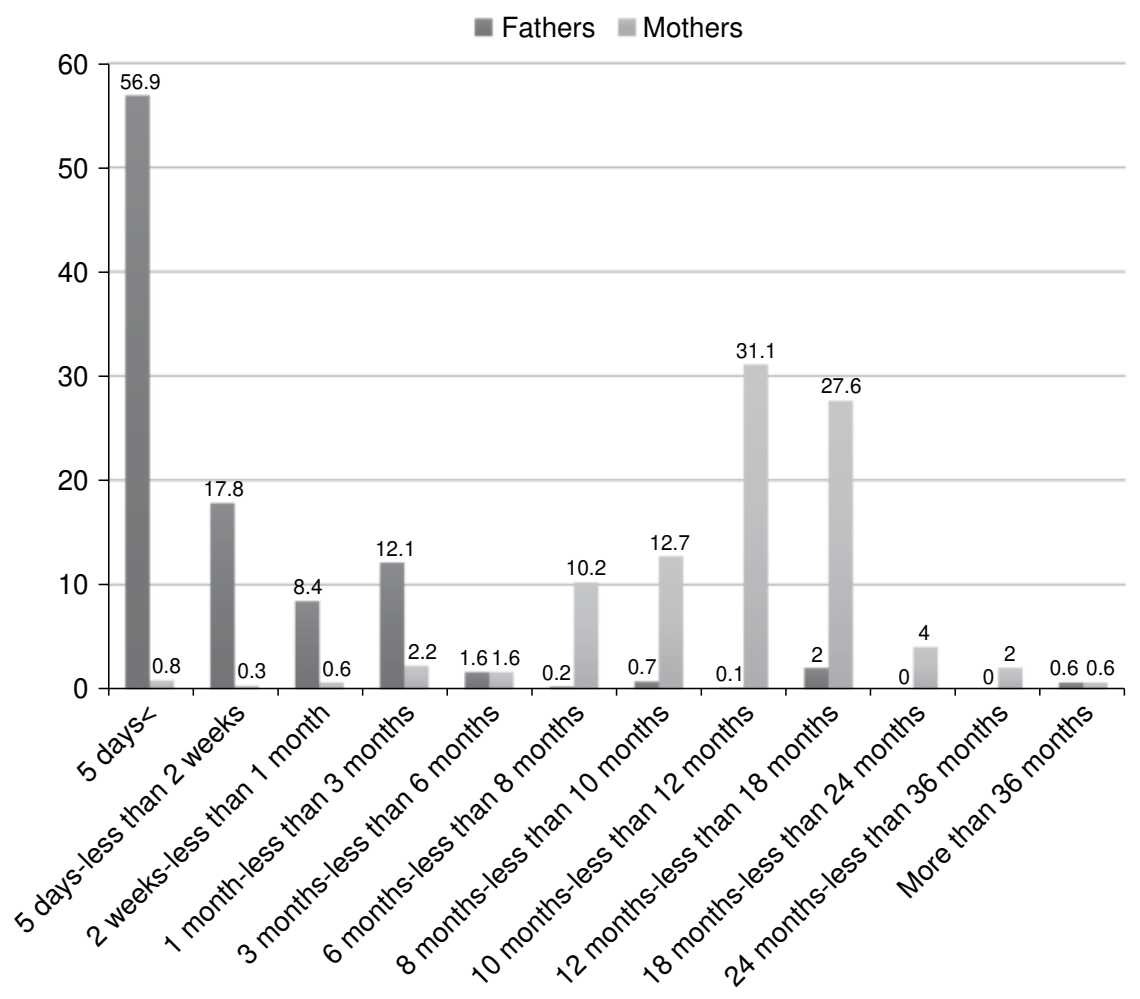

Figure 3.2 Duration of parental leave for mothers and fathers in Japan.

Source: Adapted from Ministry of Health, Labour and Welfare, 2020, figure compiled by the author.

more generous family policies, a lack of continuity in welfare discourse, the comparatively weak political influence of women and the heavy economic burdens associated with demographic ageing in Japan are factors that have constrained (and are likely to continue to constrain) the development of such policies in Japan. In addition, hegemonic masculinity is still firmly in place in Japan which gives little encouragement to any men who wishes to give priority to childcare.

Today, the debate over fathers' childcare leave continues in both countries. In Japan, for example, the head of the Ministry of the Environment declared in 2019 to take merely two weeks of parental leave but he was criticised by his fellow politicians, because they thought that the public servants should not take the leave from work for personal reasons. In Norway, the debate over abolishing the father's quota system is still alive because some argue that it is not fair that mothers and fathers are not entitled to the same length of the parental leave (Ellingsæter, 2020). 


\section{Fathers' childcare: Data comparisons}

Here, we will look at the publicly available data to compare the extent of fathers' involvement in childcare in both countries. According to the 2016 Japan's Gender Equality Bureau's comparison between Norway and Japan concerning men and women's involvement in housework and childcare, Japanese husbands spend approximately 1.23 hours/day for household labour, which includes 0.49 hours of childcare activities. The comparable figures for Norwegian fathers are 3.12 hours for household labour out of which 1.13 hours are spent for childcare activities. This comparison generates the finding that Norwegian fathers are 2.5 times more likely than their Japanese counterparts to be involved in household labour including childcare. For Japanese mothers, 7.34 hours/day are devoted to household labour with 3.45 hours used for childcare. Norwegian mothers spend 5.26 hours in household labour, which includes 2.17 hours of childcare. Although Japanese mothers spend longer time in housework and childcare than do Norwegian mothers, the gendered pattern of the division of household labour in which mothers are more likely to be engaged can be seen from these figures.

These statistics make it clear that Norwegian men are much more likely to be involved in childcare compared to their Japanese counterparts. We need to be aware that this does not assume that gender equality in childcare has completely been achieved in Norway, since mothers are still the default caretakers of their children (Ringrose, 2017; Sørensen, 2017). Additionally, mothers' and fathers' childcare participation may be different depending on the content of care. It is also important to note that fathers' childcare involvement may be different between Japan and Norway because of the differences of the daily life customs in both countries. These possibilities will be described in the following section with the data collected in both countries. Given that gender disparity in childcare involvement still exists in Japan and Norway, it is worth investigating how different factors are affecting men's childcare involvement in the two contexts.

\section{Factors predicting the levels of fathers' childcare}

We begin this section by reviewing the previous literature on factors affecting fathers' involvement in childcare in order to generate the analytical model shown in Figure 3.3. In this model, the hypotheses tested in the prior literature, such as relative resources and childcare demand, will be included along with new factors, such as men's attitudes toward gender roles at work and home.

Using quantitative data collected in the spring of 2020 in Japan and Norway, we will test this analytical model to directly compare the predictors of fathers' childcare in both countries. In other words, Japanese and Norwegian data are compared by a multi-sample structural equation model 


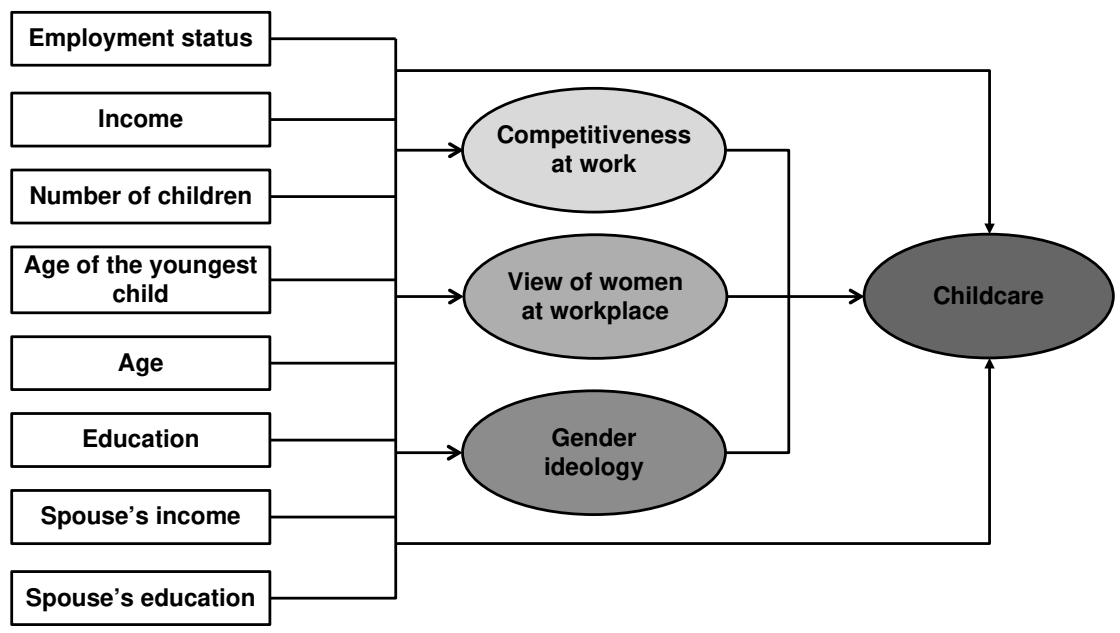

Figure 3.3 Analytical model predicting fathers' childcare involvement.

Source: Figure created by the author.

that analyses the same model using two samples, one from Japan and the other from Norway. This analysis allows the direct comparison of the estimated parameters for both countries.

\section{Antecedents to fathers' childcare}

Prior studies (Ishii-Kuntz, 2009, 2013) examined relative resources, time availability, gender ideology and childcare demands, among others, as predictors of fathers' participation in childcare. According to Relative Resources Hypothesis, husbands with more resources, such as income and educational background, than those of their wives are less likely to be involved in childcare. As for time availability, husbands who spend more time at home than those who spend less time are predicted to perform more childcare duties. Gender Ideology Hypothesis posits that husbands who hold liberal attitudes toward gender roles would be frequently involved in childcare. Childcare demands are higher when there are more children and younger children in the household, and if so, fathers are more likely to participate in childcare. Additionally, Ishii-Kuntz (2013) found that fatherfriendly practices at work and the existence of role models are positively related to men's taking childcare leave.

In our analysis, we will examine the effects of fathers' employment status, income, age, education, as well as their spouse's income and education (as indicators of the spouse's resources), and number and age of children (as indicators of childcare demands) to examine how these variables are related to fathers' childcare. We also include gender ideology as an intervening variable. 
Another dimension examined in our study is the relationship between masculinity measures and men's childcare involvement. For many years, Japanese men have been characterised by hegemonic masculinity, which emphasises the importance of their breadwinning role. As previously mentioned, in recent years, however, we have been witnessing the rise of men who are active participants in care work, including housework and childcare.

There has also been a growing theoretical and research interest in what is considered as a new form of masculinity, known as a caring masculinity, which is a masculine identity that rejects domination and embraces values of care, such as interdependence and relationality (e.g., Elliott, 2015). Although caring masculinity became a focus of many European critical studies of men and masculinity, it has never been extensively studied within Asian contexts.

Based on the explanation above, we will analyse the following model using the comparative data collected in Norway and Japan. We predict that fathers with full-time employment and higher educational attainment, who earn higher income, have fewer children, whose children are older and whose spouses' income and educational levels are lower, are less likely to be involved in childcare. In addition, these variables are predicted to influence such intervening variables as men's competitiveness at work, views toward their female co-workers and bosses, and gender ideology, which, in turn, influence their childcare involvement. Stated another way, men who are competitive at work, hold conservative views and attitudes toward their female co-workers or bosses and have traditional ideology toward gender roles are less likely to be involved in childcare. For the sake of the direct crosscultural comparison, we will analyse the same model for Norway and Japan.

\section{Methods and sample characteristics}

The data used in this research come from an ongoing cross-cultural project on men and masculinities sponsored by the Sasakawa Peace Foundation in Tokyo. The data were collected by a web survey in the spring of 2020 from married men aged 20-69 who have at least one child and were residing in Norway $(\mathrm{n}=114)$ and Tokyo $(\mathrm{n}=332)$. Initially, we aimed to collect data from the capital cities in both countries. However, given the scarcity of the Norwegian population, we needed to go beyond Oslo to collect enough data for our analysis. Thus, the Norwegian data were collected nationwide, whereas the Japanese data were collected from those living in Tokyo.

Our sample has some demographic differences among the Japanese and Norwegian men, although they are not nationally representative samples. The average age of Japanese fathers is 41.2 , about ten years younger than the Norwegian fathers (51.1). Approximately $62.9 \%$ and $50.2 \%$ of Japanese and Norwegian men, respectively, are college educated. The majority $(84.4 \%)$ of Japanese men are employed and the comparable figure for Norwegian men was 
$61.7 \%$. Dividing these men's incomes into five categories (high, somewhat high, middle, somewhat low, low), we found that $31.9 \%$ of Japanese and $50.2 \%$ of Norwegian men belong to 'high' or 'somewhat high' brackets. With respect to differences in income between husbands and wives, there is a significantly larger gap in Japan (almost 3 million yen, or 254,000 NOK) compared to that of Norwegian couples $(39,587$ yen, or 3360 NOK).

\section{Measurements}

To identify employment status, respondents were asked whether they currently are employed, employed but taking a leave or not employed. Their annual income was measured by categories ranging from 'none' to 'over 500,001 kroner' for Norwegian fathers and from 'none' to 'more than $23,000,000$ yen' for Japanese fathers. With respect to their educational attainment, they were asked to state the last school they attended. Spouse's income and education were similarly measured.

We included three questions to measure the respondents' competitiveness at work: 'I want to increase my achievement at work to receive higher evaluations,' 'I want to win the competition at work,' and 'Men are selfconscious about their status.' Responses ranging from Not at all to Very much so for these questions were added to create a scale of competitiveness. The higher score of this scale indicates men's more competitive attitudes. Cronbach's alpha is a measure of how closely a set of question items are related with the higher scores indicating greater scale reliability. These alphas were 0.809 and 0.653 for Japanese and Norwegian data, respectively. Although the alpha for the Norway sample is lower than that of the Japanese sample, we will use this scale in our analysis because we think that the questions are quite legitimate indicators of the competitiveness.

The gender ideology scale was constructed by adding the five variables: 'Men should work outside and women should care for the family,' 'Men should provide financial resources for the family,' 'Mothers need to concentrate on childcare when their child is under the age of three,' 'It is better for a woman to do housework and childcare,' and 'It is better that women care for the elderly family member.' Again, the responses to these five questions are added to create a scale of gender ideology. Cronbach's alphas were 0.857 and 0.835 for Japanese and Norwegian men, respectively. Higher scores for this scale indicate more traditional attitudes toward gendered roles.

Finally, for our dependent variable, we created a scale of 'Fathers' childcare' by adding response scores for six questions: 'Take care of meals,' 'Eat with child,' 'Help child with clothes and getting ready,' 'Take a bath together,' 'Change diapers' and 'Play together.' The response scores ranging from Not at all to Almost every day were added to create the scale of men's childcare involvement. For these scales, Cronbach's alphas of 0.870 and 0.814 were obtained for Japanese and Norwegian samples, respectively. 


\section{Analyses}

The proposed model was analysed using descriptive statistics and Structural Equation Models (SEM).

\section{Findings: Descriptive statistics}

In terms of attitudinal scales, we found that Japanese men are more likely to be competitive at work (scoring 8.38 out of 12 , with 12 being the most competitive) compared to their Norwegian counterparts (7.98). Japanese men also report more conservative attitudes toward women at work (11.26 out of 20) than did Norwegian men (9.57). With respect to gender ideology, Japanese men were again found to hold more traditional gender ideology (12.93 out of 20) than did Norwegian men (9.57).

As predicted, for childcare involvement, Norwegian men were involved in childcare much more frequently than their Japanese counterparts, though not in all categories of childcare or with uniform degrees of difference. The most notable difference was found in terms of helping the child during the meals: $49.5 \%$ and $21.1 \%$ of Norwegian and Japanese fathers, respectively, reported taking care of their children at the meal time almost every day or four to five times a week. Likewise, $30.4 \%$ of Norwegian and $21.1 \%$ of Japanese fathers frequently helped their children get dressed. In contrast, Japanese fathers were found to play with $(25.6 \%)$ and bathe $(23.1 \%)$ their children more frequently than their Norwegian counterparts $(18.7 \%$ and $20.5 \%)$. The difference in playing with children may reflect the long work hours of Japanese men. Many return home late only to be able to play with their children before bedtime rather than providing physical care. Work hours in Norway are shorter compared with men in other countries, and fathers of young children in particular have reduced their work hours over the last two decades (Kitterød \& Kjeldstad, 2003). Additionally, the difference in bathing may reflect the structural difference in which the Japanese bathroom is built to accommodate several family members at the same time.

Despite these variations, we also found that the wives in both contexts are likely to be more involved in housework than their husbands; Japanese and Norwegian husbands are involved in $32.5 \%$ and $44 \%$ of the total housework, respectively. In addition, $35.4 \%$ and $53.5 \%$ of the total childcare is performed by Japanese and Norwegian fathers, respectively. This confirms the previous finding that even in Norway, wives are 'default' providers of housework and childcare.

At the bivariate level, we found that Japanese men's competitiveness at work is significantly correlated with conservative views toward women at work and adherence to more traditional gender ideology. More conservative views toward women at work were also positively correlated with more traditional gender ideology. 


\section{Findings: Structural equation model (SEM)}

Table 3.1 shows the results of SEM based on our analytical model (see Figure 3.3). Concerning the effects of independent variables on intervening variables, it was found that Japanese men with higher income are significantly more competitive at work and have more conservative views toward women at work compared to those with lower income. Among Norwegian men, too, those with higher income reported significantly more conservative attitudes toward women at work and a more traditional gender ideology than those with lower income, which is consistent with the findings of Aarseth (2020). Those fathers who have more children hold significantly more traditional views of gender ideology compared to fathers with fewer children, and this pattern was the same in Norway and Japan.

Additionally, for Japanese fathers only, having older children was associated with holding a more traditional gender ideology. In addition, younger Japanese fathers are significantly less competitive at work, have less conservative attitudes toward women at work and have a more liberal gender ideology. Finally, Japanese wives' higher income was associated with their husbands' adherence to less traditional gender ideology.

In terms of the factors affecting fathers' childcare involvement, we found that Japanese men who have younger children and whose spouse's income is higher are more likely to be involved in childcare. For Norwegian fathers, their childcare involvement was not influenced by these factors. These direct cross-cultural comparisons show that whereas several sociodemographic variables are related to attitudinal variables, factors affecting Norwegian and Japanese fathers' childcare involvement may be quite different. This is also shown by the better fit of the model for Japanese data compared to that of the Norwegian data.

\section{Conclusions}

In this chapter, we focused on paternal involvement in childcare in Norway and Japan by comparing parental leave policies and the publicly available data. We then analysed the data collected from Norwegian and Japanese fathers in the spring of 2020 to examine factors affecting their involvement in childcare.

In terms of historical shifts in fathers' involvement in childcare, we found similar changes between the two countries. That is, both Norwegian and Japanese fathers were quite involved in childcare in earlier periods but their level of involvement decreased due to industrialisation and urbanisation. After post-war images of fathers almost hit rock bottom to the point of ridiculing and even writing off fatherhood, fathers in both countries made a comeback starting in the 1990s. In terms of parental leave policies, the two countries share certain motivations such as the emphasis on fathers' childcare involvement as beneficial to children, easing mothers' stress, and ensuring gender equality in the home. 
Table 3.1 Factors Affecting Fathers' Childcare Involvement

\begin{tabular}{|c|c|c|}
\hline Variables & Japan & Norway \\
\hline Employment $\rightarrow$ Competitiveness & -0.04 & 0.08 \\
\hline Employment $\rightarrow$ View of women at work & 0.02 & -0.05 \\
\hline Employment $\rightarrow$ Gender ideology & -0.05 & -0.05 \\
\hline Income $\rightarrow$ Competitiveness & $0.10 * *$ & 0.00 \\
\hline Income $\rightarrow$ View of women at work & $-0.13 *$ & $-0.32 *$ \\
\hline Income $\rightarrow$ Gender ideology & 0.04 & $-0.33 *$ \\
\hline Number of children $\rightarrow$ Competitiveness & -0.11 & 0.02 \\
\hline $\begin{array}{l}\text { Number of children } \rightarrow \text { View of women } \\
\text { at work }\end{array}$ & 0.07 & 0.16 \\
\hline Number of children $\rightarrow$ Gender ideology & $0.19 * *$ & $0.20 *$ \\
\hline $\begin{array}{l}\text { Age of the youngest child } \rightarrow \\
\text { Competitiveness }\end{array}$ & $0.29 *$ & -0.05 \\
\hline $\begin{array}{l}\text { Age of the youngest child } \rightarrow \text { View of } \\
\text { women at work }\end{array}$ & 0.25 & -0.04 \\
\hline $\begin{array}{l}\text { Age of the youngest child } \rightarrow \text { Gender } \\
\text { ideology }\end{array}$ & $0.34 *$ & -0.25 \\
\hline Age $\rightarrow$ Competitiveness & $-0.43 * * *$ & -0.18 \\
\hline Age $\rightarrow$ View of women at work & $-0.31 *$ & -0.25 \\
\hline Age $\rightarrow$ Gender ideology & $-0.33 *$ & -0.12 \\
\hline Education $\rightarrow$ Competitiveness & 0.07 & 0.17 \\
\hline Education $\rightarrow$ View of women at work & -0.05 & -0.02 \\
\hline Education $\rightarrow$ Gender ideology & -0.05 & 0.07 \\
\hline Spouse's income $\rightarrow$ Competitiveness & -0.08 & 0.00 \\
\hline $\begin{array}{l}\text { Spouse's income } \rightarrow \text { View of women } \\
\text { at work }\end{array}$ & -0.01 & 0.11 \\
\hline Spouse's income $\rightarrow$ Gender ideology & $-0.23 * *$ & -0.02 \\
\hline Spouse's education $\rightarrow$ Competitiveness & 0.03 & 0.00 \\
\hline $\begin{array}{l}\text { Spouse's education } \rightarrow \text { View of women } \\
\text { at work }\end{array}$ & 0.09 & -0.22 \\
\hline Spouse's education $\rightarrow$ Gender ideology & -0.02 & -0.16 \\
\hline Employment $\rightarrow$ Childcare & 0.07 & -0.14 \\
\hline Income $\rightarrow$ Childcare & -0.02 & 0.13 \\
\hline Number of children $\rightarrow$ Childcare & -0.05 & -0.05 \\
\hline Age of the youngest child $\rightarrow$ Childcare & $-0.30 *$ & -0.26 \\
\hline Age $\rightarrow$ Childcare & 0.07 & -0.28 \\
\hline Education $\rightarrow$ Childcare & 0.00 & 0.03 \\
\hline Spouse's income $\rightarrow$ Childcare & $0.15 *$ & 0.13 \\
\hline Spouse's education $\rightarrow$ Childcare & 0.00 & 0.00 \\
\hline Competitiveness $\rightarrow$ Childcare & -0.01 & -0.22 \\
\hline View of women at work $\rightarrow$ Childcare & 0.07 & -0.06 \\
\hline Gender ideology $\rightarrow$ Childcare & -0.12 & -0.08 \\
\hline GFI, AGFI, RMSEA & $\begin{array}{l}0.853 \\
0.806,0.063\end{array}$ & $\begin{array}{l}0.769 \\
0.696,0.061\end{array}$ \\
\hline
\end{tabular}

Note: $" p<0.05 ; * p<0.01 ; * * p<0.001$. Table created by the author.

Despite these similar historical transitions of fatherhood and the development of family policies, Japanese men still show reluctance to take parental leave and participate in childcare. Reasons for this gap between fathers' participation in 
childcare in Japan and Norway may owe to the differences in how parental leave policy was formulated and the lack of structural support for childcare, among others. First, allowing Japanese men to take parental leave was initiated by the government's concerns over the rapid decline of the national fertility rate. Encouraging fathers' active participation in childcare was identified as one of the driving forces necessary to encourage mothers to have more children. The Japanese government still seems to believe that fathers' use of parental leave would result in couples deciding to have more babies, despite inconsistent findings. Although parental leave and the father's quota system began as 'tools' to achieve Norway's gender equality, it was shown that parental leave is more frequently associated in recent decades with the opportunity for father-child bonding.

Second, the parental leave policy in Japan and Norway have become similar after the major revisions of the Japanese law in 2010. However, the shortage of childcare facilities after the parental leave ends is creating a major obstacle to Japanese mothers who wish to return to work. In fact, the Ministry of Health, Labour and Welfare (2017) reports that more than 20,000 children have been waitlisted to be admitted to childcare centres annually since 2010 . This shortage contrasts with the recommendation of the 2005 White Paper on the National Lifestyle which emphasizes the importance of the whole society getting involved in childrearing (Cabinet Office, 2005). The White Paper also points out that the childrearing generation is faced with a burden of taxes and pension funding for the ageing population.

The Japanese public became aware of this problem when one mother's online rant caught attention in 2016. In an article entitled, Hoikuen ochita, Nihon shine!! ('Didn't Get a Slot in Day Care Centre. Drop Dead, Japan!!') (Osaki, 2016), one mother described her frustrating struggle to find a day care centre for her child. Several dozen mothers who were inspired by the blog also held a rally in front of the Diet (Parliament) building to demand an increase in the number of day care centres while other mothers began an online campaign demanding a systemic overhaul (Osaki, 2016). Despite this campaign, however, we have not seen any significant improvement surrounding mothers who wish to return to work after taking up the parental leave.

Finally, our analyses of the data collected in Norway and Japan revealed that although sociodemographic variables, such as income and number of children, seem to have similar effects on father's childcare, none of the attitudinal variables explain the extent of paternal involvement in both countries. Thus, we need to re-evaluate the analytical model while taking into account the differences in the very meaning of paternal involvement in childcare in Norway and Japan. To this end, in-depth interviews with Norwegian and Japanese fathers asking them about the meaning of fatherhood and fathers' involvement in childcare may provide insightful findings. 


\section{Acknowledgements}

The author gratefully acknowledges the use of the Men's New Roles for Gender Equal Society, funded by the Sasakawa Peace Foundation. The survey was designed and carried out at Intage Co., Ltd. Those responsible for primary data collection bear no responsibility for the analysis and interpretations presented herein. The author also appreciates Elin Kvande for her valuable comments and suggestions.

\section{References}

Aarseth, H. (2020). Against the grain? The craving for domestic femininity in a gender-egalitarian welfare state. The European Journal of Women's Studies, 28(2), 229-243. doi: 10.1177/1350506820970241.

Atoh, M., \& Akachi, M. (2005). Low fertility and family policy in Japan in an international comparative perspective. Journal of Population and Social Security (Population), Supplement to Volume 1, 1-30. Available online at: http:// www.ipss.go.jp/webj-ad/WebJournal.files/population/2003_6/1.Atoh.pdf (accessed 15 December 2020).

Basic Act for Gender-Equal Society. (1999). Gender Equality Bureau Cabinet Office. Available online at: http://www.japaneselawtranslation.go.jp/law/detail_main? $\mathrm{re}=01 \& \mathrm{vm}=04 \& \mathrm{id}=2526$ (accessed 27 March 2020).

Brandth, B., \& Kvande, E. (2003). Fleksible fedre [Flexible fathers]. Universitetsforlaget.

Brandth, B., \& Kvande, E. (2020). Designing parental leave policy: The Norway model and the changing face of fatherhood. Bristol University Press.

Cabinet Office. (2005). Socialization of childrearing [White paper]. Available online at: https://dl.ndl.go.jp/view/download/digidepo_2942973_po_hm020303.pdf? content $\mathrm{No}=23 \&$ alternativeNo $=($ accessed 1 June 2021).

Child Care Leave Law. (1992). Ministry of Health, Labour and Welfare. Available online at http://www.japaneselawtranslation.go.jp/law/detail/?printID= \&id $=3543 \& \mathrm{re}=02 \& v m=04$ (accessed 15 June 2021).

Child Care and Family Care Leave Law. (2010). Ministry of Health, Labour and Welfare. Available online at: https://www.mhlw.go.jp/english/policy/affairs/dl/ 05.pdf (accessed 15 June 2021).

Ellingsæter, A.L. (2020). Conflicting policy feedback: Enduring tensions over father quotas in Norway. Social Politics: International Studies in Gender, State \& Society. doi: $10.1093 / \mathrm{sp} / \mathrm{j} \times \mathrm{aa} 027$.

Elliott, K. (2015). Caring masculinities: Theorizing an emerging concept. Men \& Masculinities, 19, 240-259.

Hayashi, M. (1996). Fusei no fukken [Restoration of paternity]. Chuo Koron Shinsho.

Ishii-Kuntz, M. (2009). Fathers' roles and their childcare involvement. Journal of Household Economy, 81, 16-23.

Ishii-Kuntz, M. (2013). Sociology of child caring men: In search of realizing fathers' involvement in child rearing. Minerva Publications.

Japan Institute for Labour Policy and Training. (2017). Childcare and elder care leave in Europe. Report Series No. 186. 


\section{Masako Ishii-Kuntz}

Kitterød, R.H., \& Kjeldstad, R. (2003). A new father's role? Employment patterns among Norwegian fathers 1991-2001. Economic Survey 1. Statistics Norway.

Lorentzen, J. (2013). The history of fatherhood in Norway, 1850-2012. Palgrave Macmillan.

Ministry of Health, Labour and Welfare. (2017). Hoikusho tou kanren jyoukyou torimatome (Summary of conditions related to day care centres). Available online at: https://www.mhlw.go.jp/stf/houdou/0000176137.html (accessed 19 June 2021).

Ministry of Health, Labour and Welfare. (2020). Koyou kintou kihon chousa no kekka gaiyou. [Basic survey of gender equality in Employment Management]. Available online at: https://www.mhlw.go.jp/toukei/list/d1/71-r01/07.pdf (accessed 20 June 2021).

Ohta, M. (1994). Edo no oyako - chichioya ga kodomo o sodateru jidai [Parents and children in Edo Period: Era of fathers raising children]. Chuo Koronsha.

Osaki, T. (2016). Angry blog post sparks movement for improved day care. The Japan Times. Available online at: www.japantimes.co.jp/news/2016/03/07/national/ angry-blog-post-sparks-movement-for-improved-day-care/\#.WQ7GyBSBi-V (accessed 15 December 2019).

Otoko mo Onna mo Ikujijikan o Renrakukai (Ed.) (1995) Ikuji de kaisha o yasumu yona otoko tachi [Men taking a leave for childcare]. Yukkusha.

Ringrose, P. (2017). Introduction to gender research in Norway [Paper presentation]. IGS International Symposium: Gender Equality in the Happiest Country: Gender Research and Family-Life Balance in Norway, Ochanomizu University, Tokyo, Japan.

Sainsbury, D. (1996). Gender, equality, and welfare states. Cambridge University Press.

Sørensen, S.Ø. (2017). The performativity of choice. Post-feminist perspectives on work-life balance. Gender Work and Organization, 24(3), 297-313.

Tajiri, K. (1990). Tosan wa jitensha ni note - Otoko no ikujijikan suto tenmatsuki [A father riding on a bicycle: A report about a man taking childcare hour strike]. Yukkusha.

Toivonen, T. (2007). Is Japanese family policy turning 'Nordic'? Exposing key challenges for Japan' parental leave and child care schemes. In A. Buchanen, \& M. Seeleib-Kaiser (Eds.), Barnett Papers in Social Research (vol. 1). University of Oxford. Available online at: https://www.spi.ox.ac.uk/sites/default/files/BarnettPaper20071 TuukkaToivonen.pdf (accessed 5 May 2021). 
Part II

Education 


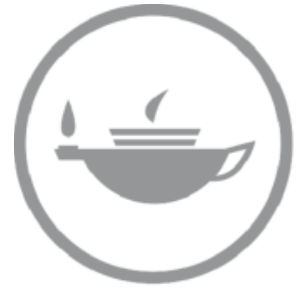

Taylor \& Francis Taylor \& Francis Group http://taylorandfrancis.com 


\title{
4 Education and gender in Japan and Norway from historical perspective
}

\author{
Ryoko Kodama
}

\section{Education and gender}

Although gender was known as a concept, its introduction into Japanese educational research did not begin until the mid-1980s. What was the background of this? Was the change unique to Japan or was it global? Focusing on Norway and Japan, this study examines these questions from a comparative historical perspective.

In comparisons of international gender gaps, the World Economic Forum's global gender gap index ranking in four subsections - economics, education, health and politics - comes to the fore. Japan ranks extremely low on the index and in recent years, has become notorious for gender gaps in various areas. Among the 156 countries indexed, in 2021, Japan ranked 120th. Always in the top group, in 2021, Norway ranked second. In stark contrast among the four subsections, Norway has a particularly high ranking in economics and politics, while Japan has a high ranking in health. The most interesting subsection is the education index, however, because Japan has paid little attention to its 92nd ranking. True, Japan ranks higher in education than in economics and politics but still below the global average. In rates of literacy and primary education enrolment, Japan ranks first globally, having achieved gender equality. Thus, its 92nd ranking in education can be attributed to its secondary and tertiary enrolment rates 129 th and 110th, respectively. In another stark contrast, Norway ranks first in both secondary and higher education (World Economic Forum, 2021).

Historically, both countries' gender-equal educational systems began at about the same time, shortly after the Second World War. So why are present rankings so different? Possible causes of higher education's gender gap in Japan include the hidden curriculum in school education, gender tracing in education, family members' gender-role awareness and sociocultural attitudes towards women. Despite various causes, Japan's educational gender gap is most pronounced in higher education, evidently from a variety of causes.

Therefore, this paper analysed factors that led to Japan's higher education gender gap, specifically, changes in education after the Second World 
War and in political and social trends during the 1970s and 1980s. The method employed was a comparative historical sociology approach. By comparing statistical data - mainly from government publications on education after the Second World War - we first clarified differences between Japan and Norway from a gender perspective.

\section{Higher education at present}

As for the gender gap in higher education enrolment rates, differences between European countries and Japan are illustrated in Figure 4.1, at which Japanese people are very surprised. They expect more men than women to be enrolled in higher education, so the reverse gap in several Western countries comes as a surprise.

Among many Western nations, percentages of women entering higher education are significantly higher than in Japan. In all Nordic countries, for instance, more women than men graduate from higher education, and only in Japan, Korea and Germany are men more likely to enter higher education. ${ }^{1}$ Figure 4.1 In Norway, more female students and, in Japan, more male students enrol in higher education. However, we should pay attention to the historical background behind these differences.

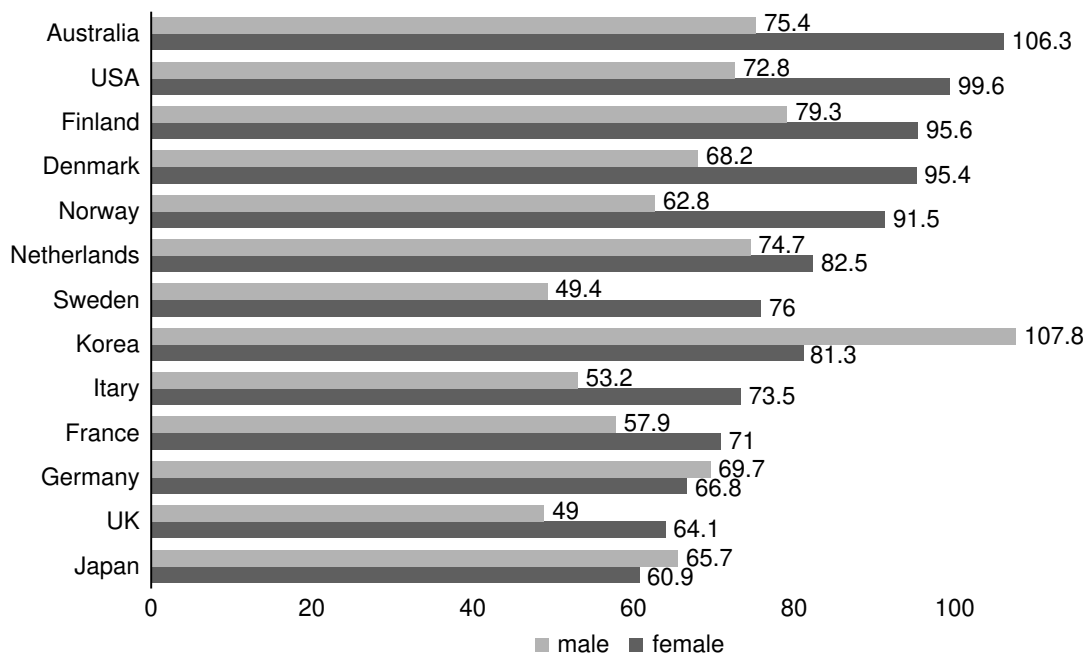

Figure 4.1 International comparison of higher education enrolment ratios.

Note. Source: Gender Equality Bureau, Cabinet Office (2018) Danjokyodosankaku-hakusyo 2018 [The white paper on gender equality 2018]. [Report]. p. 92. 


\section{Began at the same time but in different ways}

Both Japan and Norway established educational gender equality in the mid20th century, with men of both countries initially more likely to attend higher education than women. From a gender perspective, the two countries' current educational systems have their origins in mid-20th-century educational reforms, but despite similar timing, social changes magnified their small initial differences. In Norway, the School Act (Lov om Folkeskolen) was implemented in 1959 , providing nine years of compulsory education and the same curriculum for men and women. In the mid-1980s, the number of female students began to exceed that of males.

In Japan, gender issues in the educational system changed significantly in 1945. According to previous studies, before the Second World War, men and women could study together at pre-school and primary levels, but in secondary education and above, men and women were separated (Hashimoto, 1992; Hirose, 1982; Koyama, 1995). Certainly, expanding higher education opportunities and improving secondary education for women were discussed after the First World War. In practice, however, women's enrolment, with a few exceptions, remained restricted during the 1920 s, and secondary education was only partially reworked despite establishment of public and private vocational schools for women. Until the end of the Second World War, the gender-separated school system was maintained at the secondary level, and women had a lower level of education than men (Koyama, 1995, p. 6). As a defeated nation after the Second World War, Japan initiated gender equality in all systems, including enactment of a new democratic constitution. The educational system was no exception. Post-Second World War reforms were driven by the Ministry of Education, the Education Reform Commission and the Civil Information and Education Section of the occupation forces organised with democratic and liberal principles by the United States (US). Democracy in education stressed equal treatment and equal opportunities for all students, thus promoting co-education in secondary and higher education.

However, a Japanese system in which both men and women could receive the same level of secondary education was created, but in addition to coeducational schools, separate secondary schools for men and women remained. Women were allowed to attend universities, but new universities for women only were also established, thus mixing co-educational and gender-separate schools. Japanese post-war educational reform emphasised the need to promote women's education, mainly from the perspective that education was necessary for women to play an important role in society as wives and mothers (Hirose, 1982, p. 64). Furthermore, universities and junior colleges were established. In Japan's post-war educational reform, various new forms of higher education systems were created because of the previous higher education system's multiplicity. Many of the new schools lacked teachers with the necessary career experience to be recognised as 
university faculty. Post-war educational reform called for higher education's expansion, but many pre-war institutions of tertiary education did not meet conditions for recognition as universities. Some were temporarily recognised as junior colleges - partly in response to the initial expansion of community colleges in the US - and afterwards, establishment of junior colleges was approved.

In addition to four-year universities, two- and three-year junior colleges are now recognised as higher education institutions. Initially, similarly to four-year universities, more male than female students attended junior colleges. Not until the 1960s did the number of female students surpass that of males (Katayama \& Yonekawa, 1993, p. 79).

Overall, educational reform that included establishment of women's university and junior college systems had significant effects on higher education's gender balance in post-war Japan.

\section{Increase in the percentage of female students in higher education}

University enrolment rates in both Norway and Japan rose sharply in the 20th century's latter half, but examination of those rates by gender reveals highly contrasting changes, as shown in Figures 4.2 and 4.3, respectively. In Norway, education was reformed after the Second World War based on gender equality, but then, more men than women went to university, and this trend continued until the 1970s. In the 1980s, however, the ratio of men to women reversed and has continued to widen. As Figure 4.1 shows, many European countries mirror this phenomenon.

But what about Japan? Similar to Figure 4.2, Figure 4.3 shows differences in numbers of male and female students enrolled in Japanese universities during the same period. Although the enrolment rate at universities expanded during the 1970s and 1980s, gender reversal did not occur in Japan. The percentage of men in higher education expanded significantly in the 1970s, and in the 1980s, the gender gap widened. The percentage of women attending university finally began to rise sharply during the 1990s, narrowing but not reversing the gender gap.

Why does such a difference exist between Norway and Japan? Why does the number of Japanese women in higher education not exceed that of men, as in Western countries? Several reasons might explain why this trend differs in the two countries differ. One is the Japanese education system that allows segregation by gender. Although various systems in post-war Japan supposedly aimed at a gender-equal society, the process actually created a unique school system designed for women but left the existing malefavouring university system untouched. One of the most notable womenonly school systems is the Japanese junior college system. Although many women attended them, they were not included in Figure 4.3's statistics. 


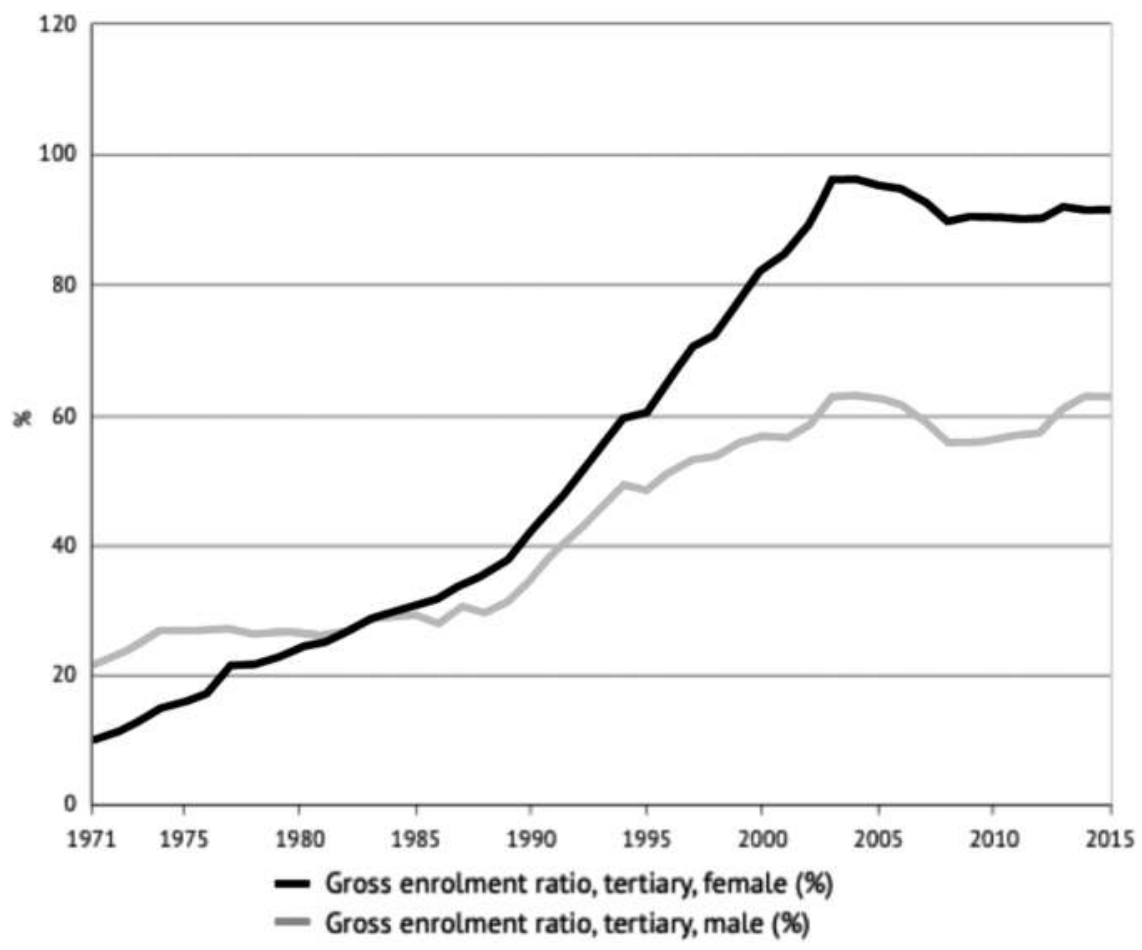

Figure 4.2 Gender differences in university enrolment rates in Norway (1971-2020). Adapted from Source: World Bank EdStats, accessed 15 Dec. 2020, https://datacatalog.worldbank. org/dataset/education-statistics.

\section{Women's junior colleges in Japan}

Figure 4.4 shows the post-war trend of higher education enrolment rates in Japan, including both universities and junior colleges. Unlike Figures 4.3, which show that the gap between men and women's enrolment rates has not been bridged, in Figure 4.4, the rates are reversed. In the mid-1980s, more women began enrolling in higher education than men, and with this, the phenomenon reversed. During that period, the same trend was also apparent in Norway.

The key to this reversal is the increase in the number of women attending junior colleges, which accounts for large part of women's participation in higher education. In other words, from the 1970s to the 1990s, the majority of women in higher education attended junior colleges in Japan. Conversely, the number of men attending junior colleges has remained consistently low. However, Figure 4.4 shows that if we include both universities and junior colleges in the statistics, more Japanese women than 


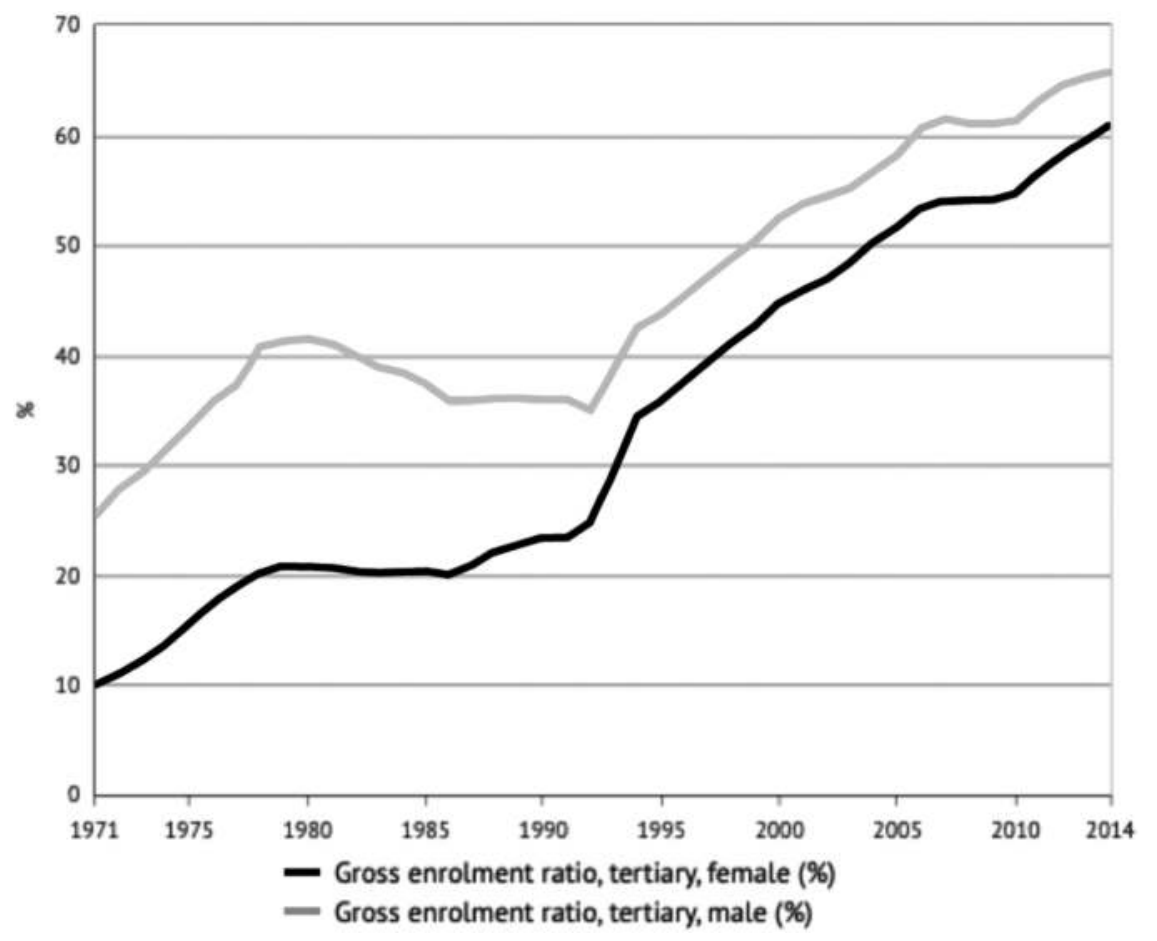

Figure 4.3 Gender differences in university enrolment rates in Japan (1971-2020).

Adapted from Source: World Bank EdStats, accessed 15 Dec. 2020, https://datacatalog.worldbank. org/dataset/education-statistics.

men enter higher education - just as in Norway. Indeed, the ratio of female junior college students can be represented by a trapezoidal shape, rising from the late 1960s, remaining unchanged until around 2000 and then falling. During this period, many women chose junior college as the path to higher education, even if only temporarily.

Figure 4.5, which displays a shape consistent with the trapezoid - like the line of only junior college women in Figure 4.4, provides a clue as to major changes in the number of junior college students. In Figure 4.5, the trapezoidal shape represents Home Economics, which, despite some variation, has clearly been the dominant major in junior colleges. In other words, the high number of Home Economics majors supported the increased number of women's junior colleges. The same was true of universities, where many female students entered departments of humanities and Home Economics (Kodama 2014).

Among junior college students, the second most common major is education, especially early childhood and elementary education. In the 1990s, 


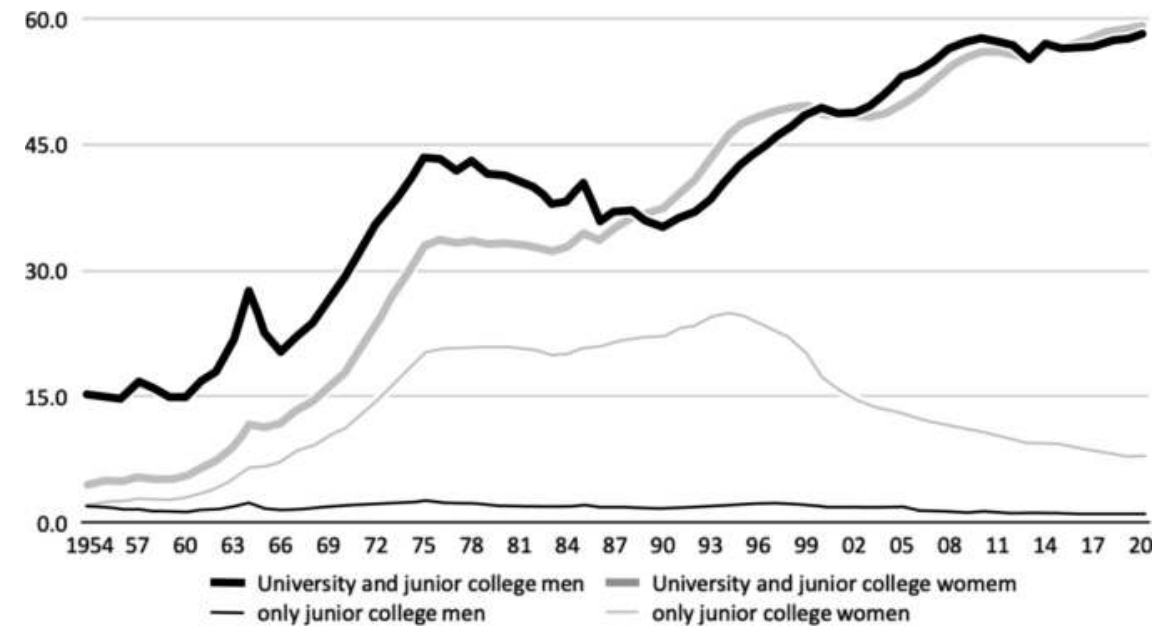

Figure 4.4 Gender differences in university and junior college enrolment rates in Japan (1954-2020).

Adapted from Source: Ministry of Education, Culture, Sports, Science and Technology. (2021). Gakko kihon chosa [Basic survey on schools], accessed 15 Dec. 2020, https://www. e-stat.go.jp/stat-search/files?page $=1 \&$ toukei $=00400001 \&$ tstat $=000001011528$.

junior colleges temporarily offered majors in humanities and social sciences, but enrolment quickly dwindled, and, again, Home Economics and early childhood education majors dominated. These majors in domestic science and childhood education might indicate that female students were expected to become housewives and mothers. In the 2000s, however, the percentage of women entering junior colleges gradually declined because women preferred university, thus leading to many junior colleges' closure and gradual replacement with universities.

Two perspectives can clarify why such a difference exists between Japanese men and women entering higher education: One is the post-war educational system, and the other is post-war Japanese society's gender consciousness. Post-war educational reform supposedly established gender equality, but establishment of women's colleges perpetuated the pre-war higher educational system. Simultaneously, junior colleges did not have the necessary conditions for higher education even though, initially, junior colleges were not created as schools for women, and more men attended them. Despite this, both women's colleges and junior colleges provided opportunities for more women to enter higher education. Importantly, despite the call for educational equality, Japanese society still held the notion that women needed education to suit their roles as housewives supporting their husbands and raising their children. As Japan's economy recovered after the Second World War, this notion gained strength. 


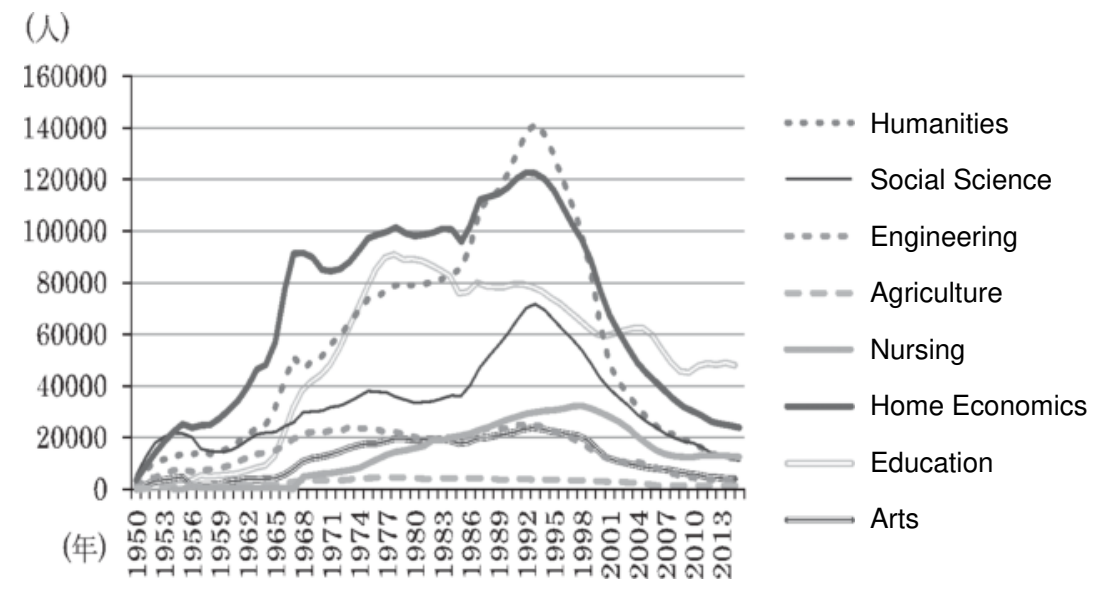

Figure 4.5 Junior college students by major in Japan (1950-2015).

Source: Suzuki, S. (2018). Sengonihon no tankidaigaku nikansuru kekyu: Kento no tameno jikikubun wo chushin ni [A study on junior college in Japan after the Second World War: Focusing on time division]. The Bulletin of the Graduate School of Education of Waseda University. Separate Volume, 25(2), p. 35.

\section{A recovering economy and the number of female workers}

As previously explained, from the late 1960s to the early 1980s, many Japanese women were attending junior colleges, majoring especially in Home Economics. Simultaneously, many women were disappearing from the job market. Figure 4.6 shows the trend in women's employment by age group, with two noteworthy points: First, from the 1960s to the 1970s, the labour force participation rate declined among women of all ages. Second, participation rates of women in their late 20 s and early 30 s declined, indicating that young women significantly disappeared from the labour scene.

As Figures 4.5 and 4.6 show, many women attended junior colleges and withdrew from the labour market during same period - linked to Japan's post-war economic recovery and changes in social structure. The mid-1950s to the early 1970s is known as Japan's period of high economic growth; the country overcame war's devastations, and average annual economic growth increased. People moved from rural to urban areas, increasing the scale of major cities such as Tokyo and Osaka. As the economy grew, workers' wages increased overall. During this period, labour unions demanded that companies pay a wage that would enable a man to provide for his wife and children. The ideal was for the husband to earn a salary and for the wife to concentrate on the home and family without having to earn a living. Workers' demands for higher wages were thus realised (Figure 4.6).

In addition to increased salaries, various institutions promoted male family members as single-income earners, and if a male worker wished, he 


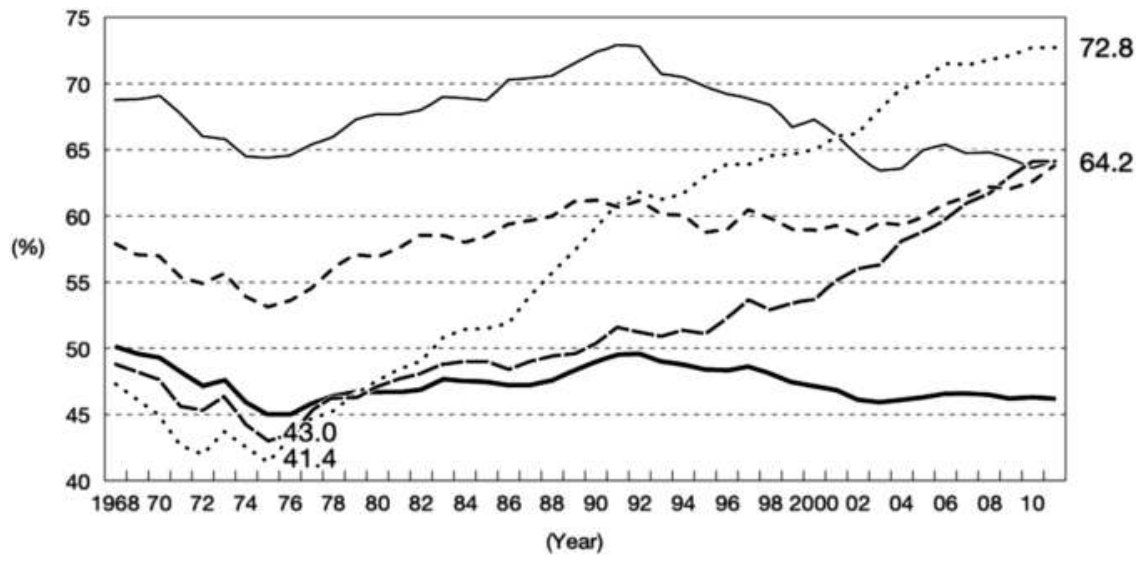

\begin{tabular}{|lll|}
\hline All ages & 20-24 years old & $\cdots \cdots 25-29$ years old \\
$--30-34$ years old & $---35-39$ years old
\end{tabular}

(Note) 1 Figures from before 1972 do not include numbers from Okinawa.

2 Due to the affects of Great East Japan Earthquake, the figures from 2011 for Iwate, Miyagi, and Fukushima prefectures are supplementary estimates.

Source) Developed by MLIT from: MIC "Labor Force Survey"

Figure 4.6 Trend in employment rates of women by age group in Japan, 1968-2010.

Source: Ministry of Land, Infrastructure, Transport and Tourism. (2014). White paper on land, infrastructure, transport and tourism in Japan, 2014. [Report], p. 24.

was granted a special 'dependent's allowance' to support his wife and children. Furthermore, if the wife did not work, tax exemptions for dependents increased the husband's total income. In the 1970s, this system undeniably led to women's withdrawal from the labour market. When the average Japanese woman married in her early 20 s, she withdrew from the workforce in her late 20s or early 30s to give birth and care for her young children. Thus, the role of women as housekeepers and educators of children, not as breadwinners, was promoted by institutions supported by economic growth. In particular, children's education became Japanese mothers' most important task.

Figure 4.7 compares how women's (age 20-54) labour force participation rates in Japan and Norway have changed over the past 50 years.

As seen in Figures 4.6 and 4.7, the labour force participation rate of women, especially those who raised children, declined in Japan as the single male earner system developed during post-war economic reconstruction and the high-growth period of the 1970s. In contrast, during the 1970s in Norway, the female labour force participation rate increased to surpass Japan's, which had previously been higher. Earlier, the female labour force in Japan was rather higher than that in Norway, but in the mid-1970s, the 


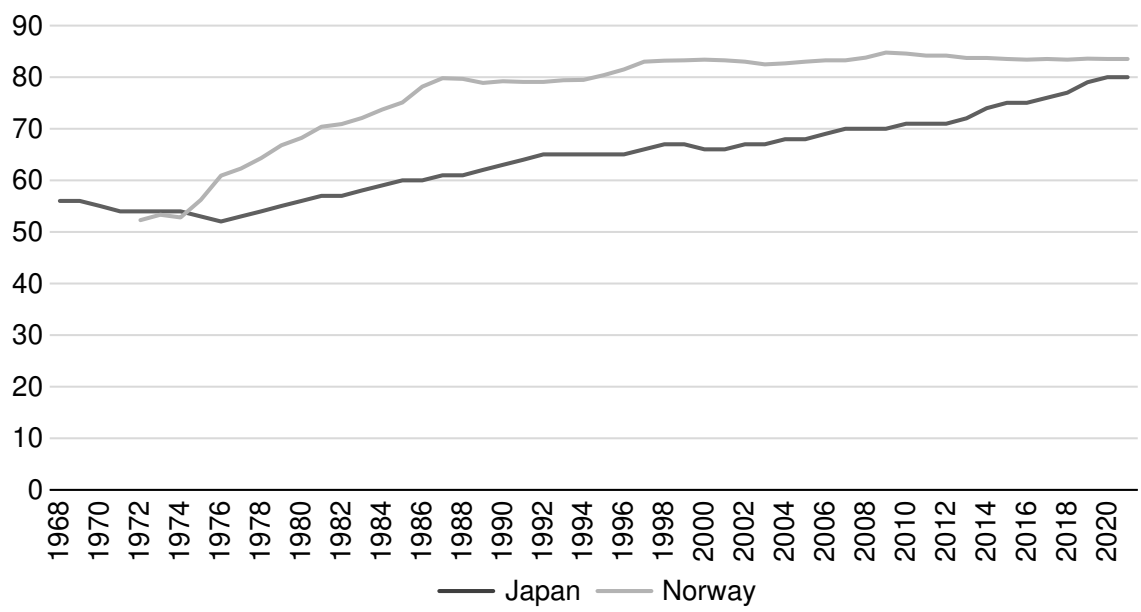

Figure 4.7 Comparison of female labour force participation rates between Japan and Norway (women aged 20-54, \%), 1968-2020.

Adapted from Source: Statistics Bureau of Japan and Statistics Norway. Statistics Bureau of Japan, Labor Force Survey, accessed 15 June 2021 https://www.stat.go.jp/english/data/ roudou/index.html. Statistics Norway, Labor Force Survey, accessed 15 June 2021 https:// www.ssb.no/en/arbeid-og-lonn/sysselsetting/statistikk/arbeidskraftundersokelsen.

two countries reversed the trend. Like Japan, Norway once strongly tended to see women's role as homemakers (Furuichi, 2019; Matsuda, 2020), but in the 1960s, Norway experienced a labour shortage and women's participation in the workforce became necessary. Significantly, Norway has been promoting gender equality laws and policies since the 1970s (Leira, 1993).

In contrast to Norway, Japan had a large working population and promoted policies based on male patriarchal roles. This explains the difference in labour force participation rates, but Figure 4.7 also shows the gap again narrowing.

\section{Economic growth and educational expansion}

Social changes and changes in the work environment subsequently affected the education system. Many families who moved to cities were not guaranteed the property they had inherited from their parents, for instance, a house. Even if they did inherit such property, they could not benefit from it as straightforwardly as those who led a life in the countryside, especially considering that they needed to build a life and support a family in the city. Consequently, they believed that education was key for a more prosperous urban life as wage earners. Entering the workforce after nine years of compulsory education was not uncommon, but at this time, parents wanted their children to attend high school for another three years. In 1950, the 
national average of students attending high school was $42.5 \%$ in Japan. By 1955 , the rate had risen by nearly $10 \%$, to $51.5 \%$. As early as 1957 , parents implored the government to build more high schools so that all children could attend high school (Ministry of Education, Culture, Sports, Science and Technology [MEXT], 1992).

These parental demands were compatible with development of national education and science policies. Japan's educational policy was also influenced by the US Education Law (1958), adopted in response to the shock of the Soviet Union's Sputnik launch. In Japan, such theories as those of manpower, educational investment and human capital have directly linked education and the economy. The 1960s witnessed a policy argument that more money should be invested in education to develop the economy. Although compulsory education was never extended beyond nine years, by the mid-1970s, over $90 \%$ of students went to high school.

Furthermore, upper secondary schools' expansion was linked to university education's subsequent expansion, and, as Japan's post-war economy recovered, the percentage of students attending its national, local government and private universities also increased. Importantly, tuition fees were not cheap. Although tuition at national and local government universities was relatively low, it was not free. Needless to say, tuition fees at private universities were much higher, but even so, the increased number of students attending universities after the Second World War was largely due to the increase in private universities.

Increased university enrolment rates also reflected that less affluent families were also pursuing higher education, sending sons to university and daughters to junior college. Even with greater opportunity for higher education, women did not need a four-year university education; two years of junior college was considered sufficient. Parents hoped their sons would get a better education and, consequently, a better job; they wanted their daughters to marry and become housewives and mothers, who needed a different education from that for a professional.

In 1959, a Japanese politician made a statement in parliament:

The role that junior colleges have played in women's education has been extremely significant. If the junior college system had not been established after the war, many women would not have had the opportunity to receive higher education. The reasons for this are the age at which women marry and the financial burden on their parents. Junior colleges are what saved women's education. (Koyama, 2008, p. 331)

Not until the 1970s, more than a decade later, did junior colleges become dominant educational institutions for women (Figure 4.4). Interestingly, the statement quoted above predicts the general status of women's education during the following two decades. 
Even though the existence of gendered junior colleges has widened universities' gender gap, they played a significant role in promoting and expanding higher education for Japanese women during the post-war period. At the same time, however, junior colleges seemed to encourage women to become housewives and mothers, thus further widening various gender gaps (e.g., economic, political) in Japanese society.

A faculty member who accepted a position at a women's junior college in the mid-1960s said in the mid-1990s, 'I have been complicit in discrimination against women and have resisted discrimination against women through my tenure at the women's junior college and through my education and research' (Yasukawa, 1996, pp. 24-5). Because junior colleges tend to prepare women to become housewives and mothers, engaging in such education seems complicit in discrimination against women. Even so, the author is a well-known researcher who has been conducting ideological research on the structure of discrimination against women in women's colleges. This author-researcher's dilemma well represents the structural problem of education in post-war Japan.

In fact, the situation of women's junior colleges changed after the 1990s, when Japan ratified the Convention on the Elimination of All Forms of Discrimination against Women in 1985, six years after the United Nations adopted the Convention in 1979. Then Japan's rapid economic growth declined, and wives' employment rates rose because their families could no longer live on their husbands' income alone. Women began to look for better jobs and better education. More female students aimed for universities instead of junior colleges, and as a result, many junior colleges closed or downsized. During this period, the gender structure hidden in Japanese education came into question, despite the system's ostensible equality. Also during this period, universities promoted gender and women's studies to provide women with empowering higher education.

\section{Current universities and their problems}

As explained above, the percentage of men who go to university is higher than that of women in Japan. However, if junior colleges are included, no gap exists between genders. Although not as high as in Europe and the US, the rate of women entering higher education is high and rising. Moreover, it must be emphasized that female students in junior colleges had a competitive motivation for learning, as pointed out by a researcher who surveyed women's junior colleges in the 1990s (Matsui, 1997). Even so, women's junior colleges earlier functioned as affirmative action, securing a place for female students to study.

Importantly, the gender gap in Japan's higher education enrolment rates disappeared during the 1980s. Also in the mid-1980s, the gender gap in higher education enrolment rates reversed in Norway. That the percentage of females in higher education exceeded that of males in both Japan and 
Norway at the same time indicates that the 1980s were an important turning point in feminism's global history. Even though female students in Japan became more motivated to study, especially at university, in the 1980s, their enrolment in women's junior colleges did not help close Japan's economic and political gender gap because many junior colleges base education on women's role as housekeepers and caregivers. Japanese junior colleges were dualistic, on the one hand, encouraging women's higher learning and on the other, keeping women in the home.

Since the 1990s, the number of junior colleges in Japan has been decreasing, and more and more female students are going to universities. In addition, women's employment rate is now increasing. It will be interesting to see how gender equality in Japan will progress in the future.

In 2018, however, a major incident came to light regarding gender in Japan's higher education. The Japan Times revealed several university medical schools to have discriminatorily manipulated university entrance examination scores in favour of men (2018). In the year following the articles' publication, female students' acceptance rate increased in many medical schools, in turn suggesting that the discrimination was real. According to the articles, medical schools wanted to avoid a doctor shortage at their universities' affiliated hospitals, believing that female doctors often resigned or took long vacations after marriage or childbirth. Japanese society was shocked to discover that such blatant discrimination against women still exists in universities. In contrast, male doctors are expected not to take long vacations, thus also revealing Japanese doctors' harsh working conditions.

Obviously, educational issues cannot be considered separately from economic, social and political issues. At first glance, education in Japan might seem to approach gender equality, but it also harbours a deep-rooted discriminatory structure that has made visible major gender discrimination in economics and society. The gender gap index does not and cannot reveal the deep-rooted structure of discrimination, thus indicating that we still have a lot of work to do.

\section{Note}

1 In particular, the high rate of male enrolment in higher education in Japan and Korea can be analysed as an Asian characteristic.

\section{References}

Furuichi, N. (2019). Norway niokeru ikuji-seisaku to danjobyodo no totatsuten: nihon tono hikaku wo toshite [Childcare policy and the reach of gender equality in Norway: A comparison with Japan]. Japanese Journal of Northern European Studies, 5, 1-11. 
Gender Equality Bureau Cabinet Office Government of Japan. (2018). Danjokyodosankaku-hakusyo 2018 [The white paper on gender equality 2018]. [Report]. https://www.gender.go.jp/about_danjo/whitepaper/h30/zentai/html/zuhyo/zuhyo0105-03.html

Hashimoto, N. (1992). Danjokyogakusei no shitekikenkyu [Historical study on coeducation system]. Otsuki-syoten.

Hirose, H. (1982). Sengo-gakuseikaikakuki niokeru danjokyogakuka nikansuru ichikosatsu [A study of coeducation in postwar Japan]. The Japanese Journal of Educational Research, 49(3), 64-72.

Japan Times. (2018, 5 September). Tokyo Medical University discriminated against female applicants by lowering entrance exam scores. https:/www.japantimes.co.jp/ news/2018/09/05/national/social-issues/men-pass-entrance-exams-women-80-japansmedical-schools-survey/

Katayama, Y., \& Yonekawa, H. (1993). Sengo-joshikyoikukai no ayumi to tankidaigaku no henyoukatei (1) [Transformation of the junior college and women's education in post war Japan (1)]. Bulletin of the Educational Research Institute of Osaka Kyoiku University, 28, 79-86.

Kodama, R. (2014). Gender to kyoiku [Gender and education]. In. H. Mimizuka (Ed.), kyoikukakusa no syakaigaku [Sociology on Educational Inequalities] (pp. 137-163). Yuhikaku Publishing.

Koyama, S. (1995). Gender to kyoiku [Gender and education]. The Japanese Journal of Educational Research, 62(3), 58-64.

Koyama, S. (2008). Tankidaigaku no joshikyoikukikanka: 1950-nendai no nibon niokeru tankidaigaku wo meguru giron/Conversion of junior colleges into women's educational institutions: The debate on junior colleges in Japan in the 1950s]. In. S. Kagawa \& S. Kawamura (Eds.), Josei to koto-kyoiku [Women and higher education] (pp. 310-336). Showado.

Leira, A. (1993). The woman-friendly welfare state?: The case of Norway and Sweden. In L. Jane (Ed.), Women and Social Policies in Europe. Edward Elgar.

Matsuda, K. (2020). Norway no hoiku-karikyuramu no kaikaku-doko: Danjokyodo nimuketa torikumi ni chakumokushite [Trends of early childhood curriculum reform in Norway. Focusing on gender equality among children]. International Journal of Early Childhood Education, 27, 123-140.

Matsui, M. (1997). Tandai ha dokohe iku [Where do junior colleges go? Gender and education]. Keiso Syobo.

Ministry of Education, Culture, Sports, Science and Technology. (2021). Gakko kihon chosa [Basic survey on schools], accessed 15 December 2020, https:/www.e-stat.go.jp/ stat-search/files?page $=1 \&$ toukei=00400001\&tstat $=000001011528$

Ministry of Education, Culture, Sports, Science and Technology. (1992). Gakusei120-nenshi [History of 120 years of school system in Japan]. Gyosei Corporation.

Ministry of Land, Infrastructure, Transport and Tourism. (2014). White paper on land, infrastructure, transport and tourism in Japan, 2014. [Report]. https:// www.mlit.go.jp/common/001113556.pdf

Statistics Bureau of Japan, Labor Force Survey, accessed 15 June 2021, https:// www.stat.go.jp/english/data/roudou/index.html

Statistics Norway, Labor Force Survey, accessed 15 June 2021, https://www.ssb.no/ en/arbeid-og-lonn/sysselsetting/statistikk/arbeidskraftundersokelsen 
Suzuki, S. (2018). Sengonihon no tankidaigaku nikansuru kekyu: Kento no tameno jikikubun wo chushin ni [A study on junior college in Japan after World War II: Focusing on time division]. The Bulletin of the Graduate School of Education of Waseda University. Separate Volume, 25(2), 33-42.

The World Bank. (2010). Educations statistics, accessed 15 December 2020, https:// datacatalog.worldbank.org/dataset/education-statistics.

World Economic Forum. (2021). The Gender Gap Report 2021. [Report]. http:// www3.weforum.org/docs/WEF_GGGR_2021.pdf

Yasukawa, E. (1996). Sengo-kotokyoiku no Gender-kozo: joshitankidaigaku deno watashi no 30-nen [Gender structure of postwar higher education: My 30 years at a women's junior college]. Quarterly Women's Education Issue, 66, 23-29. 


\title{
5 Creating more equal partnerships: Home Economics education and gender equality in Japan and Norway
}

\author{
Jennifer Branlat and Junko Sano
}

Over the years, Home Economics in Japan and Norway has developed along different trajectories but with the shared goal of opening the subject to co-educational participation. In Japan, the subject became a requirement for all students in 1994. In recent years, it has attempted to lead more men towards active participation in home life by keeping domestic and family issues on the curriculum. Norway made Home Economics classes coeducational in 1959 during a period of educational reform for gender equality. However, as the other Scandinavian countries, it has over the past decades opted to narrow its focus to 'food and health' in order to meet health-related social challenges that have supposedly become more urgent than the matter of gender equality.

Home Economics has in the past played an important role in establishing gender equality in the private sphere by educating both men and women towards domestic competence. More recently, as many countries come to promote novel forms of sustainability education, which lies at the intersection of gender equality and environmentally friendly ways of living, we see Home Economics as having a valuable role to play. Equal levels of household competence may reduce the double burden on women and support both partners in the establishment of more sustainable households. Our focus here will be Japan and Norway. In comparing these two different national frameworks, we ask: When it comes to Home Economics education, what are the key differences and similarities between the Japanese and Norwegian national contexts? What can educators and educational leaders from Norway and Japan learn from each other in order to secure a more promising future for the subject?

This chapter begins by briefly reviewing the history of Home Economics education to provide one possible explanation for the subject's diminished status in Norwegian and Japanese education. Home Economics has gone from being a subject for girls only to one which provides each individual, both boys and girls, with the skills to become independent and able to function in a gender-equal society. In the Norwegian context, we draw attention to what might be called a 'post gender equality' attitude that marks a shift in thinking about the rightful place for children and young

DOI: $10.4324 / 9781003185222-5$ 
adults to learn to perform domestic tasks and duties associated with family life. We go on to examine the current position, goals and challenges of today's Home Economics education in both countries, complementing statistics with the qualitative interviews we carried out with educators in lower secondary school and teacher training. The choice to include their perspectives in this chapter was motivated by a desire to show that although gender equality remains an important goal for family and equality policy, Home Economics teachers lack the resources - primarily due to the subject's negative associations with 'women's work' - to meaningfully support this societal aim.

Today, the Scandinavian welfare state is represented internationally as a 'model' for promoting work-life balance based on the dual-earner/dualcarer family model (Cousins \& Tang, 2004; Ellingsæter, 2009). One of the most widely documented effects of this model has been that employment rates for mothers of young children remain among the highest in Europe. If we dig deeper, however, we obtain a more fine-grained understanding of the division of household labour as it pertains to the same group. Kitterød and Rønsen (2012, p. 671) have shown that the equal sharing of paid work, which concerns only $40 \%$ of Norwegian women, is much more common than non-traditional arrangements whereby a woman would work more than her partner ( $10 \%$ of women). Even if the gap between the total time spent by men and women on household tasks and childcare has been greatly reduced since the 1970s, women with young children still spend approximately twice as much time on household tasks and childcare than men. This unequal sharing of household tasks creates a double burden situation whereby women have the responsibility for paid work in the labour market as well as an unequal share of unpaid work in the household. Household work duties are also highly segregated by gender in Norway, as is the case for many other countries (Hook, 2010). Drawing on various studies, Seierstad and Kirton (2015) have contended that 'the domestic division of labour in Norway seems more impervious to state policy measures' than other arenas (p. 394).

In Japan, the Cabinet Office's 2019 survey of about 8000 men and women examined the division of housework and showed that among couples without children, women spent 2.6 times as much time on housework as men in households with couples. When it comes to households with children, women spent from 2.8 to 3.6 times as much time on housework as men and 2.1 to 2.7 times as much time on childcare (Gender Equality Bureau, Cabinet Office, Government of Japan 2020). Even though men's time spent on housework has increased gradually over the past decade in Japan, women still bear most of the burden of household work.

In the light of this current situation for both Japan and Norway, we would like to reflect upon the purpose and relevance of current Home Economics education by asking: Does the subject have the potential to contribute to a more equal distribution of domestic responsibilities? In 


\section{Jennifer Branlat and Junko Sano}

which ways does Home Economics education in its current (as of 2020) form in Japan and Norway support the creation of a more gender-equal society? In regards to the latter, we refer to the United Nations' Sustainable Development Goals (SDGs), the fifth of which targets 'the promotion of shared responsibility within the household and the family as nationally appropriate' (United Nations General Assembly, 2015). If Home Economics education in Norway and Japan continues facing significant challenges - such as meagre budgets for classroom learning activities, low ranking within the 'the traditional curriculum hierarchy' (Bleazby, 2015, p. 261), the constant reduction of required study hours and relatively few male teachers - how will it be able to contribute to gender equality?

\section{Home Economics, modernisation and the legitimisation of women's education}

It is important to note that the history of Home Economics education in Japan, as in Norway, is closely related to the history of traditional women's work (Øvrebø \& Engeset, 2020; Makino, 2005). Even prior to the modernisation of Japan in 1868 and the subsequent creation of the national education system in 1872, women were responsible for weaving and sewing fabric for underwear and bedding, as well as clothing for their families. Sewing, considered to be a distinctly women's art, endures even today as a part of the Home Economics curriculum. In Japan, during the late 1930s as part of the war effort, Home Economics was doubled in number of hours, and classes were dedicated to the production of supplies in support of the nation. The subject also contributed in pedagogical terms to the emergence of the 'good wife, wise mother' ideology whereby women performed citizenship through raising and educating children while men became part of the national community by engaging in production activities or military duties (Koyama, 2014, p. 97).

In the Norwegian public school system, Home Economics education has undergone many changes since its initial adoption into school curriculum in 1908, but the subject traces its roots back even earlier to 1865 and the creation of the first 'housewife school' ('husmorskole'). Such schools, which arose alongside agricultural schools and where women obtained specialised instruction in domestic subjects, were part of the modernisation of Norway. From its very beginnings in a rural context, the question of healthy eating habits has always occupied a central position (Øvrebø \& Engeset, 2020, p. 11). The increasing number of housewife schools from the mid-19th century onward reflects the state's objective to both formalise and professionalise knowledge (Larsen \& Hagemann, 2011, p. 267) with respect to the home - an initiative that was reinforced by the schools' connections to developments in nutritional science and the natural sciences, particularly microbiology. This initiative gave women a new standing in the family and society, even as it marginalised them. The schools were also instrumental in 
the development of the 'housewife ideology' in Norway, which aimed to 'strengthen the position of the housewife in modern society' and delineate the nature of suitable work for women (Melby, 1989, p. 184). In particular, the Statens loererinneskole for husstell (The State Teacher Training School for Housekeeping), created in 1909 in the city of Stabekk, became what Larsen and Hagemann (2011, p. 268) called a 'hub' for the development of housekeeping as an academic subject, making great strides towards expanding housekeeping outside the home and pushing towards its recognition as a science. The creation of the school in Stabekk, with its attendant networks of public and private actors, also significantly marked 'a cohesive attempt to define housework as something more than just housework. It was about knowledge, work, identity and consumption' [emphasis in original] (Larsen \& Hagemann, 2011, p. 268).

The school reform of 1959, which led to the creation of the mandatory nine-year school (niårig skole), aimed to erase disparities between urban and rural areas and offer equal opportunities to all pupils. This reform secured gender equality a prominent place in the post-war modernisation of Norway. The act also had implications both for Home Economics as an emerging science and for the development of gender equality among pupils. On the one hand, one can see the first manifestations of legal-based gender equality reform in the Norwegian public school system in that all curricular differences between girls and boys were abolished, leading to the elimination of reduced hours in theoretical subjects for girls. Until that time, a gender-divided curriculum stipulated that boys be offered more hours in math and sports, and while girls were offered courses in sewing and domestic arts, boys learned carpentry and crafts. From 1959 onwards, both home knowledge and handcrafts became obligatory subjects for all children. The school reform of 1959, with aims toward gender equality, ironically marked the end of the traditional women's higher education institutions. This was particularly the case for the aforementioned activity clustered around the Statens loererinneskole for husstell, which was, along with other women's-only institutions, transformed into a co-educational teaching college (Larsen \& Hagemann, 2011). Considered in this light, it emerges that initial efforts to create gender-equal conditions in schools were also responsible for dismantling a pillar of women's knowledge, food and nutrition science, which connected women to the more prestigious natural sciences, like microbiology.

As for post-war Japan, in 1968 the field changed dramatically when junior high school 'Vocational and Home Economics' became 'Technology and Home Economics,' and the Ministry of Education divided the subject content along gendered lines with designated content reserved for boys and girls. This change is reflected in how, throughout the 1960s, Japanese corporations strategized to get more workers skilled in STEM by pressing the government to use education to build a skilled workforce. As a result, girls were offered cooking, clothing production, home mechanics/home 


\section{Jennifer Branlat and Junko Sano}

crafts, design/drawing and childcare, while boys' instruction included wood and metal working, design and drafting, electricity and mechanics. This emphasis reflects the fact that Japan's rapid economic growth was dependent on the government's promotion of a gendered division of labour, with men engaged in production work and women doing domestic work (see Murase, 2005).

After the Second World War, Home Economics education in Japan was influenced by the government's policies and ideals of gendered citizenship and differentiated education. During the period of rapid economic growth from the late 1950s to the early 1970s, the number of full-time housewives increased. In high schools, Home Economics in Japan went from an elective subject to a compulsory subject for girls, starting in 1970. The 1994 Convention on the Elimination of All Forms of Discrimination Against Women, which Japan signed, became the driving force behind making Home Economics a co-educational subject for all students. According to Kano (2011), the years 1995 to 2005 may go down in history as a decade when 'gender' became one of the most visible and hotly contested terms in Japanese political discourse.

In Norway, the progressive emergence of the dual-earner model and the distancing of women from the home during 1970s feminist movements meant that both boys and girls could learn to participate on equal terms in family and domestic life. Continuing in the same direction, support for family policy and gender equality reached a peak with the election of what is known as the 'women's government' of 1986 under the leadership of Norway's first female prime minister. The subsequent 1987 issue of the school plan marked a pinnacle for Home Economics teaching in Norwegian public schools. Not only were the number of teaching hours increased, but the curriculum had been revised to establish a clear focus on the practical skills (diaper changing, food preparation and housekeeping skills, to name a few) necessary for the equal division of household labour. In 1987, the presence of gender equality as a curricular theme was also strengthened. Following this peak for gender equality in Home Economics education, practical domestic skills were progressively phased out and hours reduced, making it today the subject with the least amount of teaching hours. In addition, the decline of domestic skills and gender equality as a curricular theme can be traced to the broader shift towards more neoliberalist and individualistic thinking in public policy and to a perception that gender equality has been achieved.

\section{Home Economics education from 2000 onward}

Home Economics in Japan now encompasses a wide range of fields, including not only food, clothing and shelter but also learning about family and childcare; it moreover engages students in consumer and environmental education (Ito, 2019). Currently, it consists of three main subjects: Family 
and home life; food, clothing and housing; and consumer life and environment. It is intended as a practical, 'hands-on' subject that engages pupils in experiential learning to acquire not only knowledge but also skills and techniques. Since 1994, it has been a compulsory, co-educational subject in primary, lower secondary and upper secondary school while the required teaching hours for Home Economics have steadily decreased since 1947.

In Japan, Home Economics in high schools has also undergone significant changes. The 1994 revision of the national Courses of Study boosted the required hours considerably, making mandatory a four-credit course for boys and girls. However, in 2003, during the conservative backlash of that decade, an alternative format was introduced - a two-credit course called Basic Home Economics. According to a survey by Nonaka et al. (2015), $63 \%$ of high schools in the Tokyo metropolitan area have switched to this reduced version of the course. As a result, the number of full-time Home Economics teachers has also decreased, with many schools having only one full-time teacher. This decline in teacher numbers raises questions about the consequences of a weakened professional network and the implications that it has for curricular innovation, teamwork and experience-sharing among teachers.

In Norway, from 2006 onward, the subject has been more clearly contextualised in a health and healthy lifestyle perspective to meet the societal challenge of preventing obesity and diet-related chronic diseases like diabetes. Today, the subject area is therefore represented by a compulsory 'Mat og Helse' (Food and Health) course that is further broken down into three subject areas: Food and lifestyle, food and culture, and food and consumption.

It is helpful to situate the current Food and Health curriculum - which aims to establish a solid foundation for enhanced physical and mental health and social well-being and social equity - more broadly within the 2020 governmental school reform. In light of this new framework, Food and Health is designed to teach students that skills related to food and meal preparation are of great importance to mental, physical and social wellbeing, and that the promotion of healthy eating habits and knowledge about nutrition have the capacity to lower social inequalities with respect to health.

Food and Health therefore has an ambitious mandate within the Norwegian societal context, but numerous studies have shown that the subject's lack of prestige within the public-school system have led to uneven and substandard practices in schools (Vik et al., 2020). In a recent study, Vik et al. (2020, p. 53) showed that in spite of national requirements, only half of current Home Economics teachers in Norwegian lower secondary schools possess formal qualifications to teach the subject. More recently, Bottolfs (2020) has shown through empirical research that teachers with a high level of formal competency in Home Economics demonstrate 
significantly better teaching practices with respect to 'choice of dishes, study materials and [sufficient] focus on the student's health and the theme of obesity' (p. 191).

In contrast to Norway's focus on dietary health, Japanese Home Economics has retained a broader thematic focus. In elementary school, for example, Home Economics' goals include developing the ability to relate better to others. It is also overtly focused on cherishing the notion of 'Japaneseness,' whereby children are educated on the importance of Japanese lifestyle and culture with regards to food, clothing and housing. In junior high school, cooperation continues to be emphasised; students learn about issues and practices in family and community life. At the senior high school level, themes include social change and the promotion of a sustainable society, dietary education, cooperation between men and women to build a family, understanding of the role of parents and child-rearing support, understanding the elderly, lifestyle planning, consumerism and environmentally friendly lifestyles, and the inheritance of Japanese lifestyle and culture (Sato, 2021). Despite this rather comprehensive list of themes connected to contemporary society, there is little to no explicit mention of gender issues in the teaching plan. Self-reliance, however, appears to have become greatly valued in today's high school curriculum in Japan, just as it has in Norway - which makes sense given the introduction of individualistic, neoliberal values into curricular thinking and rationales.

On the matter of gender equality in Japan, much attention has been paid in recent years to the question of whether the introduction of co-education in Home Economics in 1994 has brought about any significant changes in the attitudes and behaviour of women and men. Concerning women, a survey of 502 employed mothers in 2014 found that Home Economics courses influenced their ability to plan for the future and enhanced their sense of life fulfilment (Sano, 2016). Men who studied Home Economics in its co-educational form since it began in 1994 are now part of the childrearing generation. Compared to men who studied before 1994, their views on family and gender roles point in a revolutionary and gender-free ${ }^{1} \mathrm{di}-$ rection (Nakanishi, 2011). Ishii-Kuntz (2013) has argued that the recent 'Ikumen phenomenon' in Japan - the rise of so-called 'good-looking' men who actively participate in raising children - has been closely linked to Home Economics education. Overall, Home Economics education has clear contribution to make in reducing Japan's gendered division of labour and in promoting men's behaviour in housework and childcare.

\section{Current teachers' perspectives on Home Economics}

In this section, we present the results of our qualitative study of teachers' perspectives on the relationship of Home Economics education to gender equality. Interviewees were asked about the following: Their motivation for working in the field, what they believe is unique about the subject of Home 
Table 5.1 Breakdown of Interviewees by Name, Country, Age and Current Position

\begin{tabular}{|c|c|c|c|c|}
\hline Name & Sex & Age & Affiliation & $\begin{array}{l}\text { Current } \\
\text { position }\end{array}$ \\
\hline Mika (Japan) & $\mathrm{F}$ & $50 \mathrm{~s}$ & $\begin{array}{l}\text { National university, Advanced } \\
\text { Practice of School Education }\end{array}$ & $\begin{array}{l}\text { Associate } \\
\text { Professor }\end{array}$ \\
\hline Yumi (Japan) & $\mathrm{F}$ & $40 \mathrm{~s}$ & Public high school & $\begin{array}{l}\text { High school } \\
\text { teacher }\end{array}$ \\
\hline $\begin{array}{l}\text { Mariko } \\
\text { (Japan) }\end{array}$ & $\mathrm{F}$ & $50 \mathrm{~s}$ & $\begin{array}{l}\text { National university, Family Studies } \\
\text { Pedagogy, Department of Life } \\
\text { Sciences, Faculty of Education } \\
\text { and Science }\end{array}$ & $\begin{array}{l}\text { Associate } \\
\text { Professor }\end{array}$ \\
\hline Emi (Japan) & $\mathrm{F}$ & $50 \mathrm{~s}$ & $\begin{array}{l}\text { National university, Graduate } \\
\text { School of Education }\end{array}$ & Professor \\
\hline $\begin{array}{l}\text { Marit } \\
\text { (Norway) }\end{array}$ & $\mathrm{F}$ & $40 s$ & Public lower secondary school & $\begin{array}{l}\text { Middle school } \\
\text { teacher }\end{array}$ \\
\hline $\begin{array}{l}\text { Lisbeth } \\
\text { (Norway) }\end{array}$ & $\mathrm{F}$ & $50 \mathrm{~s}$ & $\begin{array}{l}\text { National university, Department of } \\
\text { Teacher Training }\end{array}$ & Senior lecturer \\
\hline $\begin{array}{l}\text { Solveig } \\
\text { (Norway) }\end{array}$ & $\mathrm{F}$ & $50 \mathrm{~s}$ & $\begin{array}{l}\text { National university, Department of } \\
\text { Teacher Training }\end{array}$ & Senior lecturer \\
\hline $\begin{array}{l}\text { Gunhild } \\
\text { (Norway) }\end{array}$ & $\mathrm{F}$ & $40 \mathrm{~s}$ & Public lower secondary school & $\begin{array}{l}\text { Middle school } \\
\text { teacher }\end{array}$ \\
\hline
\end{tabular}

Economics in terms of academic content, the ways in which they approach teaching, salient differences (including gender) in the classroom, how they would like to see the subject evolve in the future, and the ways (if any) in which the curriculum and/or teaching approaches integrate the concept of 'gender equality.' The data was collected over a three-month period, from October to December 2020, in the form of semi-structured interviews. The survey participants were recruited in a snowball style from our initial contacts. The interview duration was one to two hours. Interviews in Norway were conducted in English and interviews in Japan were conducted in Japanese. A total of five university-level educators in Home Economics at national universities and three high or middle school-level Home Economics teachers were interviewed (see Table 5.1).

All of the university faculty members are principal members of the Japanese Society for Home Economics Education ${ }^{2}$ and have published Home Economics textbooks. As university faculty, Mika, Mariko and Emi are quite passionate and proactive, and while they can be considered leaders in the field of Home Economics education, they may not provide a representative picture of Home Economics teachers across Japan whose motivations and professional qualifications may differ. On the Norwegian side, it proved difficult to contact formally educated Home Economics teachers, given that roughly half of teachers in Home Economics in Norwegian lower secondary school do not have any formal education in the field and not all teacher training programs offer such a specialisation. Two 
university-level educators in Home Economics, Lisbeth and Solveig, were recruited from a prominent teacher training program in southern Norway offering a Home Economics specialisation. At the lower secondary level, we reached out to three schools in the Sør-Trøndelag region and recruited two teachers currently teaching in Home Economics: Gunhild has three to four years of experience in primary and lower secondary education, and Marit has over 15 years of experience in various primary and lower secondary schools in the region. As part of the data collection phase corresponded to the shift to online teaching due to pandemic-related school closures, all interviews took place online.

\section{Teachers' overall focus}

Much like the Japanese teachers, the Norwegian teachers report that there is no intentional or explicit focus on 'gender' or 'gender equality' in the school curriculum. It is assumed that all pupils participate equally in the cocreation of food and other practical exercises, irrespective of gender. When asked about how they approach the subject, their responses reflected a narrow focus on food preparation. The keywords that emerged from the interviews in Norway were 'creativity,' 'challenge' and 'diversity,' suggesting that experimentation and improvisation are important skills to free students from the idea that one mistake will ruin a recipe. Developing these attitudes takes priority over skill building. As Marit explained,

Everyone needs to be able to participate and feel the joy of cooking. I want my students to learn how to be independent. They can do this by learning and exploring their creativity. I don't want them to feel that cooking is rigid and that they are bound by rules.

Both current classroom teachers put great emphasis on the ways in which they perceived the practical subjects like Food and Health to be more inclusive and welcoming to diverse student abilities. According to Marit, 'Students should be able to read a recipe and collaborate in groups with the understanding that everyone has something to contribute....Creating a cosy environment is key; it opens up something different than the theoretical subjects. Discovery is important.' Similarly, in Japan, Yumi explained, 'I choose assignments that can be completed in a short period of time and value the students' sense of accomplishment. In Home Economics, kids who don't stand out in other subjects can show their individuality.'

In Japan, in 1947, after the Second World War, the topics covered in Home Economics were not limited to food and nutrition, but shifted from sewing to democratic family relations, and now include a wide range of topics such as food, housing, childcare, consumer education, environmental issues and even financial education. The interviews with teachers suggest that the goal of Home Economics in Japan is for students to acquire 
knowledge and skills to support self-reliance. Equally, they should develop the ability and desire to understand the function of the family and to improve their lives. Mika explained,

I want students to be aware of everything and learn new things. I want them to be able to do things if they try, and to value a sense of accomplishment. I want them to have life skills and to have a perspective on their life stages.

\section{Gender equality as an implicit value}

Both Japanese and Norwegian teachers claim at first that they do not consciously teach about gender-related issues in her classroom, nor do they perceive any gendered division of labour in the practical tasks. Norwegian classroom teachers reported no gender-related differences in skill level among their students. They did, however, point to differences related to the level of home support, pointing out that socio-economic factors influencing the home may play a more significant role than a student's gender: 'For some students [cooking activities] give them a greater chance to thrive and showcase their skills, for others [who have no chance to cook at home] it's like going to the moon' (Gunhild).

In Norway, Solveig shared the belief that the conceptualisation of Food and Health as an essential subject at the political level, which has an increasingly individualistic and neoliberalist approach, has contributed to a sidelining of gender equality and women's contributions to the field:

It's the politicians who obviously don't understand that Food and Health could be a foundation...for the new curriculum. They don't see it as connected to the interdisciplinary theme of 'democracy and citizenship', which is crazy because think of gender, for instance, which is so important in Food and Health. The pioneers of the field in the 19th century saw gender as a focus, and they even made Food and Health schools for boys in Sognefjord. Much of the aim of the subject was of course to level the differences in the society - that has a lot to do with democracy and citizenship, so it's a missed opportunity.

The transition to Food and Health from the 1980s focus on domestic tasks and gender equality reflects the view that newly emerging societal problems such as obesity should take priority because gender equality has already been achieve in Norway. Solveig sees the potential contribution of Food and Health in a broader perspective regarding the role it can play in reducing social inequality overall.

For their part, Japanese interviewees claim that male students participate in the class without any tangible sense of discomfort. However, in 
conversations between students during class, Yumi sometimes sees them making value judgments based on gender, such as, 'It's strange that you're a girl and you're not good at Home Economics,' or 'It's amazing that you're a boy and you're good at sewing.' In schools, there is a tendency to emphasise theoretical subjects related to university entrance examinations, and therefore home economics classes that involve practical skills are neglected. She also feels that the content of the classes, with the recent reductions in required hours and the resulting time constraints, have rendered the classes broad and shallow, making it difficult for students to learn skills such as cooking and sewing in a meaningful way.

Mariko, associate professor at another university that also trains Home Economics teachers, also responded that she herself does not talk about gender equality emphatically to her students. One of the classes she teaches is called 'Research on Teaching Materials,' in which student teachers freely choose teaching materials and present them during seminars. Mariko has noticed a recent increase in the students who choose 'gender equality' as their theme. She worries that university students are interested in marriage couples working together to do housework and childcare in their own lives but they are unable to develop teaching materials where they can actually try their hands at it. In fact, she has little experience in teaching with hands-on teaching materials. Many classes end with writing on a printout or reading a textbook. Home economics classes need to have a balance between 'theory and practice,' she said.

According to the response of the students in Emi's college class and feedback from in-class discussions, most male students would like to take childcare leave in the future. However, when asked who will cook the meals and clean the house during the period of leave, few of these male students answered that they will do it themselves. Rather, they assumed their future wives will do it. In response, Emi stated that it is essential for everyone to learn domestic skills in Home Economics classes.

\section{No more washing temperatures, no more ironing: A home life built on creativity}

When asked about the absence of skills related to housework and other domestic tasks in the current Food and Health curriculum, the university educators in Norway were not entirely in agreement. Lisbeth expressed a sense of relief that the subject no longer addresses domestic tasks such as laundry and ironing:

I'm glad that [Home Economics] doesn't include learning about these kinds of tasks anymore. In the past, there was nothing in the curriculum about gender equality in the kitchen because there was no gender equality. It was more about how to iron your tablecloth and how to divide different clothes to different washing temperatures. I'm happy 
that that's out. That should be taught in homes so that in school we are free to focus on something else. The household division of household labour in the home fits more in the social sciences than my view of Home Economics as a topic.

For Lisbeth, domestic tasks reflect an outdated image of the subject, reflecting a time when Home Economics played a role in locating women's work in the home and, in her view, was associated with the carrying out of very unimaginative tasks. Lisbeth expresses a sense that the subject today should be more open and concerned with building a life based on independence and creativity. Regarding her student teachers in Food and Health, she reports,

I want for them to feel so secure in their skills, the specific cooking skills, but also the didactics, so that they can also leave the control to students and let them be creative. Because it seems now that by the time we get our student teachers into their third year of teacher education, we have somehow 'uncreativitied' them. When they are finally able to think outside the box, that that's when the fun starts and that's when the magic happens. It's not just about replicating some oppskrift [recipe] or doing something the way we always did. That's not how to build a life.

From this perspective, Lisbeth wants to promote the idea that a home life shared together is less about the carrying out of uninventive, uninspiring tasks than it is about innovation and creativity. In her view, taking an academic approach to the household division of labour would be more fitting to the social sciences. Solveig on the other hand perceived the omission of domestic skills as an unfortunate legacy of feminism's endeavour to liberate women from the home. This suggests a tension in Home Economics in Norway between teachers who wish to focus on skills and those emphasising attitude development.

\section{Domestic skills for a fulfilling life}

Both concerns - skills and attitude development - emerged in the Japanese interviews, too. The keywords that emerged from the Japanese educators' interviews are 'housework skills' and 'sense of accomplishment.' The student teachers expressed that they wanted both boys and girls to learn housekeeping skills and to have a sense of accomplishment that they could do this if they tried. For example, Emi states,

I see value in raising children well, building strong marital relationships, balancing professional and family life, and this can be achieved through domestic skills. No matter how many ideas of gender equality 


\section{Jennifer Branlat and Junko Sano}

and caring and kind words we have, it will be completely meaningless without domestic work skills. It is very important for both men and women to have the ability to live independently. I have the impression that Home Economics is divided into two areas, one dealing with human relations and the other with things.

Achieving gender equality in Japan will require individual independence, and consumer, environmental and financial education: Critical knowledge about food, clothing and housing is essential. Although the subjects of this survey responded that they did not pay special attention to gender equality in their classes, they spoke of their intention to not pursue gender equality actively in their classrooms but rather to help all students acquire the life skills required to realise a gender-equal society.

\section{Discussion}

In both Norway and Japan, the challenges associated with the field of Home Economics as described in the research literature came up in the interviews with teachers. They identified tangible roadblocks that prevent them from accomplishing the curricular objectives. In particular, in Norway, the reduced number of hours, lean budget and low status of Food and Health as an academic topic perpetuate attitudes that the subject is less important than theoretical subjects. Further, the idea that learning about domestic tasks and the equal sharing of household work should take place in the private sphere - and not take up valuable space in the school curriculum - was suggested as one of the benefits of the relatively new focus on Food and Health. The Japanese case is similar. Although Home Economics has been recognised as fundamental to developing individual independence, gender equity, collaborative ability and life skills, it too has experienced diminished support in terms of hours, budget and prestige. Many high schools have only one full-time teacher, who is eventually replaced by a part-time teacher. In addition, in both countries, a high percentage of Home Economics teachers are women, and the percentage of students studying Home Economics education at universities is also overwhelmingly female. This trend has not improved to date. The image that Home Economics in Japan is an activity for women has not been completely eradicated.

The most significant difference between Norway and Japan in Home Economics education today concerns the place allocated to the learning of domestic skills in the curriculum. With the focus narrowed to Food and Health following public health concerns over obesity, domestic skills in Norway are today absent from the school curriculum and relegated to the private sphere. In Japan, domestic skills still form an important part of the curriculum. They are based on the idea that such skills make, in the words of one teacher, 'raising children well, building strong marital relationships [and] balancing professional and family life' more possible. However, like 
Japanese teachers, Norwegian educators expressed ideals of a home life based on freedom, creativity and the cultivation of joy in food preparation. The trained Home Economics educators in higher education were divided on the absence of domestic skills in the current curriculum. Some of the interviewees viewed domestic skills rather negatively, associating them with the housewife era and an outdated image of women's work. Others lamented the loss of these skills that potentially reduce social inequalities. In the words of Solveig, 'How can we assume that such skills can be acquired at home when we don't assume the same for other subjects? Why should domestic skills be an exception?'

Today the notion of gender equality in Norway, one of the so-called 'model' countries for work-life balance and gender equality, is covered only theoretically in the social studies curriculum in spite of persisting inequalities within the home concerning the sharing of domestic tasks. We might ask for future research, what is lost when students approach gender equality in theoretical terms (e.g., in social studies) and fail to gain the embodied knowledge provided by the development of hands-on skills? Our study also supports the literature on the current challenges facing the subject by introducing teachers' lived experiences with such difficulties.

While the curricular content of Home Economics in Japan has become increasingly broadened, Norway has chosen to narrow its focus to food and health. Domestic skills and family care, which figured most prominently in the curriculum during the mid-1980s, have been phased out. This may be due to a prevailing cultural attitude that these skills are best cultivated within the space of the home, but more research on Norwegian attitudes towards domestic work is needed to complement the body of literature on time sharing within the home.

Although similar cultural attitudes may be in play in Japan, there is a movement to rethink housework in a 'modern' way, as represented in the KonMari Method ${ }^{3}$ by Marie Kondo whereby rooms are cleaned and organised in creative and meaningful ways. Our interviews with Home Economics educators in Norway suggest that, much like their Japanese counterparts, they embrace the development of creativity and ingenuity as valuable assets in the curriculum, but their potential impact on the home has been limited due to the subject's instrumental turn toward Food and Health in the 2000s and by negative cultural attitudes concerning domestic tasks due to their association with the housewife era in Norway when women's workplace primarily limited to the home. We believe that Norway can learn from the idea that daily housework and domestic tasks may provide an outlet for creative thinking. Developing a more positive association with such activities can help students to lead more fulfilled lives.

On the other hand, Japanese Home Economics may have a good deal to learn from the Norwegian context. According to Furuichi (2019), gender equality in Norway did not start with an ideology. As the expansion of the welfare state in the 1960 s led to a shortage of labour and rising prices, it 


\section{Jennifer Branlat and Junko Sano}

became difficult for a single man to make a living, which in turn led to the participation of women in the workforce. Japan is currently experiencing a labour shortage due to the declining birth rate and ageing population, putting it in much the same situation as Norway 60 years ago. Japan also needs to learn from Norway's policies, social welfare system and awareness of gender equality.

Finally, in both countries, Home Economics should be given a more prominent and prestigious place in the overall curriculum as societies around the world seek out more sustainable and ecological ways of living both at the household and societal levels. Research and practice should be used to show how environmentally friendly and gender-equal home management can contribute to society in the future, and adequate class time should be reserved for this.

\section{Notes}

1 'Gender free' is a Japanese term meaning free from the imposition of historical, cultural and social gender differences. But this term also incited right-wing backlash in Japan.

2 Landslaget for mat og helse i skolen (LMHS) is one of the Norwegian equivalents.

3 The KonMari Method (2021) encourages tidying by category - not by location beginning with clothes, then moving on to books, papers, komono (miscellaneous items), and, finally, sentimental items. Keep only those things that speak to the heart, and discard items that no longer spark joy.

\section{References}

Bleazby, J. (2015). Why some school subjects have a higher status than others: The epistemology of the traditional curriculum hierarchy. Oxford Review of Education, 41(5), 671-689.

Bottolfs, M. (2020). Mat og helsefaget i dagens skole [Food and health studies in today's school]. Norsk Pedagogisk Tidsskrift, 2, 181-193.

Cousins, C., \& Tang, N. (2004). Working time and work and family conflict in the Netherlands, Sweden and the UK. Work, Employment and Society, 18(3), 531-549.

Ellingsæter, A.L. (2009). Leave policy in the Nordic welfare states: A 'recipe' for high employment/high fertility? Community, Work and Family, 12(1), 1-19.

Furuichi, K. (2019). Norway niokeru ikujiseisaku to danjobyoudou no toutatasutenn:nihon tono hikaku, Kita yo-roppa kennkyuu. Japanese Journal of Northern European studies, 15, 1-11.

Gender Equality Bureau, Cabinet Office, Government of Japan. (2020). Balancing work and housework/childcare/caregiving: how do individuals, households, and society face the issue? https://www.gender.go.jp/english_contents/about_danjo/ whitepaper/index.html.

Hook, J.L. (2010). Gender inequality in the welfare state: Sex segregation in housework, 1965-2003. American Journal of Sociology, 115(5), 1480-1523.

Ishii-Kuntz, M. (2013). 'Ikumen' gennshou no shakaigaku [Sociology of child caring men]. Minerva Shobo. 
Ito, Y. (2019). Series kennkyu no doukou kateikyouiku no doukou [Trends in research series]. Nihon kasei gakkaishi [The Japan Society of Home Economics], 70(12). https://doi.org/10.11428/jhej.70.845

Kano, A. (2011). Backlash, fight back, and back-pedaling. International Journal of Asian Studies, 8(1), 41-62.

Kitterød, R.H., \& Rønsen, M. (2012). Non-traditional dual earners in Norway: When does she work at least as much as he? Work, Employment \& Society, 26(4), 657-675.

Kondo, M. (2021). KonMari Method: Fundamentals of tidying up. KonMari Media, Inc. [Trademark]. https://konmari.com/

Kondo, M. (2014). The life-changing magic of tidying: A simple, effective way to banish clutter forever. Ebury Publishing.

Koyama, S. (2014). Domestic roles and the incorporation of women into the nationstate: The emergence and development of the 'good wife, wise mother' ideology. In A. Germer (Ed.), Gender, nation and state in modern Japan, 85-100. Routledge.

Larsen, E. \& Hagemann, G. (2011). Husmorens foranderlighet [The housewife's changeability]. Tidskrift for Kjønnsforskning [Journal for Gender Research], 34, 267-273.

Makino, K. (2005). Kateika no kako genzai mirai [The past, present and future of Home Economics]. Kateikakyouiku [Home Economics Education], 79, 6-11.

Melby, K. (1989). The housewife ideology in Norway between the two World Wars. Scandinavian Journal of History, 14(3), 181-193.

Murase, M. (2005). Kateika to gender [Home Economics and gender]. Doushisha jyoshi daigaku sougou bunka kennkyuusho kiyou [Bulletin of Institute for Interdisciplinary Studies of Culture, Doshisha Women's College of Liberal Arts], 22, 33-44.

Nakanishi, Y. (2011). Dannjyo kyoutsuu hissyuu kateika no seika to kadai [Effects and issues of coeducational Home Economics]. Nibon kateika kyouiku gakkaishi [Japan Association of Home Economics Education], 53(4), 217-225.

Nonaka, M., Kamei,Y., Shinyama, M., Arai, K., Arai, T., Ishijima, E., Niyama, M., Sanada, C., \& Taklahashi, R. (2015). Koukou kateika dannjyo hisyuugo 20nen no risyuu kannkyou no kennshou [Learning environment of co-educational Home Economics in senior high schools for 20 Years: Through curriculum investigation in 4 prefectures in Kanto District]. Nihon kateika kyouiku gakkaishi [Japan Association of Home Economics Education], 58(2), 79-89.

Øvrebø, E.M., \& Engeset, D. (2020). Fagdidaktikk $i$ mat og helse (2nd ed.). Cappelen Damm akademisk.

Sano, J. (2016). Kateika no manabi no ninnshiki to jyosei no syuurou to seikatsu manzokukann [The Effect of Home Economics on Women's Work-Styles and Life Fulfillment: A Comparison of before and after coeducational home economics education]. Nihon kateika kyouiku gakkaishi [Japan Association of Home Economics Education], 59(1), 24-34.

Sato, Y. (2021). Kateikakyouiku ni okeru kajiroudou no atukai to sono benyou -Shakaiteki kadai ya seisaku no doukou nichakumoku site-[Treatment of housework in Home Economics education: Relationship with social issues and the government policies]. Nihon kateika kyouiku gakkaishi [Japan Association of Home Economics Education], 63(4), 191-202. 


\section{Jennifer Branlat and Junko Sano}

Seierstad, C., \& Kirton, G. (2015). Having it all? Women in high commitment careers and work-life balance in Norway. Gender, Work \& Organization, 22(4), 390-404.

United Nations General Assembly. (2015, 21 October). Transforming our world: The 2030 agenda for sustainable development (A/RES/70/1). [Report]. https:// www.refworld.org/docid/57b6e3e44.html

Vik, F.N., Beinert, C., Palojoki, P., Hillesund, E.R., Engeset, D., Ask, A.S., Åbacka, G., \& Øverby, N.C. (2020). Differences in formal education among Norwegian Home Economics teachers. Journal of the International Society for Teacher Education, 24(2), 45-59. 


\title{
6 Teaching with feminist values: A dialogical narrative analysis of gender studies educator narratives
}

\author{
Jennifer Branlat
}

\section{Gender studies education in a transnational perspective}

This chapter explores the ways in which Gender Studies educators in Norway and Japan position themselves in educating their students. With a curriculum that leads students to examine critically the complex web of gender and its intersections with sexuality, race, power relations, marginalisation and coloniality, both teacher and student may be naturally led to reflections on inequalities within the institution of higher education itself. Indeed, teaching in higher education takes place within an institutional context that has traditionally excluded women and their histories from the realm of what constitutes 'legitimate knowledge.' The overarching question I ask is the following: How do Gender Studies educators in Norway and Japan situate and position themselves pedagogically within the discursive landscape surrounding Gender Studies as it exists in the academy today? To what extent is there room for a transnational 'we' in Gender Studies education that might benefit from collective pedagogical strategies? What is to be gained by examining Gender Studies education in Norway and Japan in a cross-cultural perspective?

This study is exploratory in the sense that there is no well-defined body of scholarly literature on Gender Studies pedagogy in either Japan or Norway. In addition, proceeding with numerous uncertainties about the extent to which cultural distinctions effect educator positionings, I found it fitting to use a method unobtrusive enough to allow me to listen for influences and possible connections between teaching practice and feminist theory. Arthur Frank (2012) borrows from Bakhtin's concept of 'polyphony' to show how one's voice is never entirely one's own, but instead is rife with 'the voices of specific others' (p. 3). In this chapter, I analyse four narratives by Gender Studies educators (two from Norway, two from Japan) and use the term 'voice' to signal moments where the listener - in this case a fellow teacher and researcher - can perceive such echoes most clearly.

Gender Studies - formerly 'Women's Studies' - in both countries became institutionalised in the wake of second wave feminism, yet the processes leading to the legitimisation of the field over the years have been quite different. The same can be said for other factors - namely, the place of feminism 
within Norwegian and Japanese academic institutions, co-educational versus segregated learning environments, the culture of the workforce students are prepared for and the increasing internationalisation of higher education. All of these contextual elements and more have the potential to influence how educators position themselves in their classrooms. Most importantly, an exploration of these different positionings may tell us more about the possibility of transnational cooperation. Is there a 'we' to be found among Gender Studies educators in Norway and Japan? It is my hope that this exploratory comparative approach will also serve as the basis for future educational collaboration between the two countries. As a backdrop for further analysis, I will in the following section review literature on pedagogy in higher education to bring out differences in the Norwegian and Japanese contexts.

\section{Pedagogy, feminism and the role of the educator in higher ed}

'Pedagogy' is a term more widely used than ever before in the context of higher education research literature. It has been defined by Stommel and Morris (2018), scholars and critical pedagogy educators as the bigger picture of teaching:

Pedagogy is praxis, insistently perched at the intersection between the philosophy and the practice of teaching. When teachers talk about teaching, [they] are not necessarily doing pedagogical work, and not every teaching method constitutes a pedagogy. Rather, pedagogy necessarily involves recursive, second-order, meta-level work. Teachers teach; pedagogues teach while also actively investigating teaching and learning. (paragraph 5)

It is no longer limited to the field of educational science alone. ${ }^{1}$ Concerns for pedagogy have gradually come to find a place within many fields and often recognise the specificity of disciplinary knowledge and adapted teaching practices (see, e.g., Chick et al., 2012; Land et al., 2008). This has occurred in higher education institutions all over the world as different strands of pedagogy have emerged. Paolo Freire's model of critical pedagogy, for example, questions traditional modes of knowledge transmission and advocates for a shift away from what is known as the 'banking model' of education whereby students are seen as passive recipients of knowledge (1970). The practice of critical pedagogy has led to more active and discipline-specific ways of engaging students by promoting the value of questioning traditional models of knowledge transmission.

In Japan, however, it has been quite rare to discuss the notion of 'pedagogy' in higher education. It is much more common to do so at the middle school and high school levels. According to Japanese sociologist and well-known feminist Chizuko Ueno, critical and feminist pedagogy's 
distance from the disciplining space of higher education can be explained in the following way based on her own experience:

The method that I used [in my classroom teaching] was a Western-style teaching method based on the principle of efficiency. It is a method that allows students, from beginner to advanced-levels, to read an enormous amount of literature in accordance with the context of the course, so that they will be able to make international-level arguments in a short period of time. In Women's Studies, which is supposed to be free of efficiency and productivity, it is a dilemma to prioritise efficiency. As a result, the distance between professionals and amateurs [in Women's Studies] has become wider and wider. (1999, [my translation])

Ueno's words reflect an understanding of the university as a professionalising space dedicated to training students as researchers adept in scholarly debates and competitive as professionals of Women's Studies in a maledominated academic job market. ${ }^{2}$ As a result, pedagogy in Japanese higher education, Women's/Gender Studies included, has not been a primary concern.

With higher education's institutional focus on the end result of teaching internationally competitive researchers - attention is drawn away from the effective pedagogical practices of teachers. This is also exacerbated by the fact that research is often more highly valued than teaching. Much less scholarly attention has been devoted to what Schulman (1987) calls the 'wisdom of practice' - that is, the knowledge that guides the actions of skilled teachers (p. 11). He is particularly interested in what might be considered the 'art' of teaching or the ways in which teachers are guided by or manage ideas within classroom space. Very seldom do colleagues have the opportunity to bear witness to each other's wisdom in action since there is an obvious ' $\mathrm{I}$ ' singular in the act of university teaching, resulting in a lost opportunity: Or,...the best creations of its practitioners are lost to both contemporary and future peers' (Schulman, 1987, p. 11). In Women's/ Gender Studies, Schulman's 'wisdom of practice' has primarily been documented in the literature on feminist pedagogy emerging from an Anglo-American context.

\section{Speaking with educator narratives: A dialogical narrative approach}

The pedagogy narratives presented in this study are set into dialogue with one another using Arthur Frank's Dialogical Narrative Approach (DNA) (Frank, 2005; 2012). The central role that narratives play in this study is underscored by Jerome Bruner's (2003) claim that autobiographical narration in its diverse forms 'should be viewed as a set of procedures for "life making"' (p. 692). Bruner questions what meaning-making we engage in 
when we 'construct ourselves autobiographically,' asking how that process may reflect a constructivist approach to narratives as quintessentially 'interpretive' events rather than a verifiable transcription of what actually happened. In this study, particular consideration must be given to possible differences in the Norwegian and Japanese contexts:

Indeed, one important way of characterizing a culture is by the narrative models it makes available for describing the course of a life. And the tool kit of any culture is replete not only with a stock of canonical life narratives... but with combinable formal constituents from which its members can construct their own life narratives: canonical stances and circumstances, as it were. (Bruner, 2003, p. 694)

Frank further claims that individuals have finite means at their disposition 'stability of narrative resources' $(2012$, p. 5) - but that these never fix our identities into stable creations. DNA asks of the researcher that she respect five 'commitments' in approaching human stories. The first commitment involves acknowledging that the notions of 'voice' and 'story' are never the pure and individual forms of expression we believe them to be. An individual's voice exists rather as a patchwork of previously verbalised fragments, a 'dialogue between voices' (Frank, 2012, p. 3). It is up to the researcher to discern the presence and tease out the relationship between these different voices rather than construct a static, 'objectified image.' In this light, the researcher's role is that of a careful listener. Thus, my analysis teases out the multiple voices interviewees use in narrating their experiences of teaching in the Gender Studies classroom.

Fieldwork was conducted in Norway from February 2019 to October 2020 at the Center for Gender Research of a prominent state-funded research university. Although the Center does not currently have a BA program, it does offer a one-year program, as well as $\mathrm{MA}$ and $\mathrm{PhD}$ programs in Gender Equality and Diversity. The MA program, which is taught primarily in Norwegian, attracts students from rural and urban areas with diverse disciplinary backgrounds and typically enrols between 7 and 15 students per year. Faculty teaching in these programs noted a steady uptick in recent years' enrolment, however, which they attribute to the change in the program's name from 'Gender Studies' to 'Gender Equality and Diversity.' The new name reflects current societal ways of discussing themes related to gender, making it more appealing to students.

I interviewed a total of ten educators, six from Norway and four from Japan. Informants reflected different generations (four senior teaching faculty in their 60s, two in their 50s, three in their 40s, and one in her late 30s - all identify as women) and diverse disciplinary backgrounds (sociology, literature, anthropology and rural studies). My position in this study was that of a researcher, teacher and colleague to my informants. This chapter is part of a larger study on teaching and learning in Gender Studies that involves both 
students and teachers in Norway. Planned fieldwork in Japan (spring 2020) was interrupted by the COVID-19 pandemic, which shifted data collection from a face-to-face to an online mode. I recruited four educators (all professors, all women) through my professional network and through subsequent snowballing from Gender Studies programs at one women's university and one co-educational university in the Tokyo area. The four interviews presented in this chapter were all conducted in English and were selected based on my interest in: 1) Presenting an equal number of Japanese and Norwegian interviewees, 2) reflecting a diversity of educator positions and 3) limiting the number so that the interviewee's stories speak for themselves to the greatest degree possible.

\section{Life experiences and disciplinary teaching}

This first story was told by Noriko, a senior professor at a women's university in Japan. After completing her postgraduate studies and cultivating a successful career abroad, Noriko returned to Japan in 2010, motivated by the sense that she had much to offer the highly motivated women students at the women's university where she currently works. In our interview, Noriko talked about her initial contact with the discipline of Women's Studies as a 'coincidence, a pure accident,' but one which allowed her to subsequently engage in deep meaning-making processes about her own family life:

I grew up in a family where my father did most of the housework and childcare. Constantly throughout my childhood, I asked myself why my family was so different from other families in Japan. Because at the time moms were doing the cooking and other domestic tasks. In my family it was always my dad who did them. My mother never really participated in domestic tasks: Childcare, housework, cooking and cleaning. I grew up with this big question in my head that was never really answered until I went to university and took courses in Women's Studies and family sociology. So that was a very, not just intellectually, but personally, stimulating experience for me, to have finally found my answer...not one but many answers.

Here, Noriko invests the discipline of Women's Studies with personal meaning by talking about how it provided 'not one but many answers' to the dissonance she experienced early on between gender roles in her family and those of Japanese society in the 1950s. She narrates her entry into the discipline with an introspective voice, representing it as the end of a quest - the arriving at an explanatory framework for her earlier lived experience of difference. Her use of the reflexive tense in 'I asked myself' and the way in which she suggests that the burning question was 'in [her] head' locate the pursuit as an interior one, unable to find an outlet in other 'objective facts-based courses': 


\section{Jennifer Branlat}

I couldn't really relate to the content of 'objective' facts courses like math or Spanish, and therefore couldn't get excited about learning. I received good grades, but that's because I studied hard, it's not because I was truly motivated to learn. When I first took family sociology or sociology of women, I was really inspired by this professor who was teaching the course. She was in her late 40s or something. She often talked about her own family, her own upbringing, and her own personal kinds of issues, not all of which I could relate to simply because we came from two different cultures. I was, however, kind of inspired by the fact that she was a single mom with five kids whose husband had deserted her... [I saw] how a very tragic experience turned into very positive one. Instead of using professional vocabulary, she was really trying to explain, to use her own examples about certain concepts that otherwise may have been difficult for students to understand.

Noriko speaks very positively of her Family Sociology course and locates her eagerness to learn in the professor's willingness to share personal experiences. When I asked Noriko if she perceived her Women's Studies or 'sociology of women' courses to be unique in this way, she offered a clear distinction between 'objective' subject areas that require the memorisation of facts and the motivational and inspirational dimensions of Family Sociology - which encourages a more 'investigative' process. Noriko's use of the comparative voice shows how she sets Women's Studies against the grain of an academic tradition that values objectivity and professionalism, and formulaic 'hard' work. Her storyteller voice then enters to express awe and give shape to the professor's transformation ('how a tragic experience turned into a very positive one') in a way that mirrors Noriko's own period of uncertainty followed by understanding, which served as a catalyst for a lifelong interest in the field.

The initial encounter with the Family Sociology professor and the opening of an alternative academic world in which life experiences have a role to play in student learning led Noriko to develop her own style of teaching. When I asked Noriko if she saw this as a distinctly 'feminist' approach, she traced her genealogy back to a 'great teacher' rather than particular feminist ways of thinking:

But if you ask me if I have always been aware of feminist thinking or ideology, I would say no. I just did it in my own style, which has been influenced by many great teachers I've had in the past.

Noriko proceeds to elaborate on her own teaching style and the ways in which she approaches her students today. She draws from an understanding of her classroom as a family as she begins to narrate about her practice: 
By sharing my own experiences and my family's experiences, [students] get interested. They are always interested in our personal lives. Even without revealing too much, I can talk about, particularly in family sociology class, sibling rivalry. I talk about my daughters, my two daughters always fighting with each other [laughs], and things like that. Students can get very interested in things like that. I don't mind, I'd rather be talking about my own experiences if that helps my students to understand.

The mother's voice became most prevalent at the end of our interview when Noriko explained how she was known on the campus as the 'mother' and that she had come to see her students as her 'children.' This mother's voice carries several sub-voices and emerges as something quite complex: A caring voice that wants the students to develop through learning, an empathetic voice and an expert voice as reflected in 'a consciousness of how they might learn something' based on her more than 20 years of teaching:

I am known as 'mother of [university neighbourhood campus]'. Students come to me as a mother figure. Even the students who I only know a little bit through my regular class! They might come to me with their love problems to seek my advice. I say, ok, I can listen to you. I'm not a counsellor, so I cannot give you counselling, but... As I've gotten older, I've begun to think of my students as my own kids. What would my kids think if I taught it this way? As a parent of a student attending a university, I want my kids to be interested in the topic and want [them] to learn more. So, it's not just how I feel, but it's also the... how do you call it? An awareness or consciousness of how they might learn something. I don't know how to explain it. But I tend to think that way.

Noriko's story of her approach to teaching is presented in a long-term perspective and grounded in her own experiences with Women's Studies as a student. She finds her own experiences in the classroom more helpful than any formal notion of 'feminist pedagogy.' Her recognition that a teacher's personal experiences - narrated as stories - have an important contribution to make in the learning encounter can also be explored in dialogue with student resistance to learning, as we will see in Takako's story.

\section{Alienation and student resistance}

Takako is also a senior professor and experienced teacher whose background is in Arts. She teaches in Gender Studies but also in liberal arts courses that bring in gender perspectives. In our interview, Takako spoke from the standpoint of someone who teaches at both a women's university and a co-educational university in the same city. Takako also related her 
current identity as an educator and teaching strategies to her own experiences as a student, having attended only women's universities herself:

I went to a girl's high school and then on to a women's university and the graduate school of that same women's university. During my studies, I attended a literature club at a nearby co-ed university. That was quite a culture shock to me! I knew that when I wanted to do something, nobody would stop me among those girls. I wasn't the leader type, but I still had the awareness that I could do anything I wanted. At the co-ed university, the roles of girls and boys were strictly divided. I couldn't have been a leader there even if I had wanted to. As girls at an all-girls high school, we had to do everything on our own.

When I asked if she perceived this environment to be 'empowering,' Takako was quick to answer to the contrary: 'To me it was very natural. When somebody wanted to do something, nobody would stop her. Rather, they would encourage her and support her.' The atmosphere of the all-girls high school is voiced in terms of the lack of gendered obstacles. She describes her own response to this environment as positive in that it enabled her to take control over her life course. Takako's teacher's voice, presented in a nurturing collective voice, emphasises the continuity of past and present: 'At [a women's university] we encourage our students to do whatever they would like to do, and there is no limit. The unwritten or implicit pressures from the larger societal environment are of course still there.' Takako presents external societal pressures as potentially undermining the teacher's collective efforts, and the nurturing voice is suddenly silenced by the looming observation with which she ends her thought.

I invited Takako to talk about how she engages students in learning. She began by stressing the importance and power of representation in naturalising a particular worldview:

I think the power of representation has a stronger capacity to make us think that something is 'natural'. If you were told not to attend higher education and just get married, then you rebel; but if you're shown pictures and images over and over, it becomes natural for you to believe that this is the world. We examine traditional representations, but then I show them something that alienates, the Guerrilla Girls performance group, for example, their poster of a nude with a gorilla head [with the text, 'Do women have to be naked to get into the Met. Museum? Less than $5 \%$ of the artist[s] in the Modern Art section are women but $85 \%$ of the nudes are female.'] But anyway, I try to have them think, and each time I try to have them articulate responses [in] their own words. I don't think I teach them how to fight, but I get them to think of about the power structures of this world. 
Takako's story presents thinking and fighting as two possible feminist stances with respect to the world outside the classroom. 'Not teaching them to fight' argues against the implicit voice of a more radical feminism. This stance comes up again in the interview in a different context when Takako discusses educators' obligation not to produce radical feminists but women who can go off and work in society. The moderate feminist and teacher's voice come together to advocate for thinking over fighting as a means to work for change within a system.

Takako comes across as a reflective, experienced educator adept at navigating students' emotional thresholds. Using a strategy of alienation, a technique developed in experimental theatre to shock the audience and keep them from investing too much emotionally in a performance, she exposes her students to difficult themes. Her story reflects an awareness that it is pedagogically desirable to push students outside their comfort zones, but that such a strategy can lead to student resistance and shutdown:

A certain percentage of students who have been raised in a conservative milieu, sometimes they just can't take it. At [a women's university], the students - almost all of them are very serious. They might come to me and say: It's too hard for me to deal with this stuff. And then I give them a different question or a different perspective. I start out with the mythology and move on to art, performance art, and Disney, how women's bodies get commodified in anime these days - practices that disgustingly commodify teenage girls' bodies. When they see themselves in this representation, in their own daily life, suddenly they are like 'ooooh!' But I do want them to be aware that their own sexuality, the young female body, is fetishised, commodified and circulated in the market. They are the objects. I want them to be aware of that.

Takako explains student resistance in terms of individual student backgrounds and recognises that not all students are able to confront the images she chooses to use initially in class. With this in mind, she skilfully balances a sensitivity to students' reactions with pushing students towards the discomfort of alienation. It is only once the students are more comfortable that she proceeds with more provocative ideas and images. Her somewhat firm voice during this passage is counterbalanced by a conciliatory voice that makes room for students to work at their own comfort level. Her teacher's voice finds purpose and meaning in creating the distance that allows for critical reflection:

Through writing you can create a distance, that's the purpose of alienation. You can look at [a work of art or image] more objectively. I don't force them to judge anything, but as long as you understand something analytically then you can take it or leave it, fight for it or fight against it. That's my goal. I don't agitate them, sometimes I want to, but I don't do that. I just want them to think critically. Take a step back. 


\section{Jennifer Branlat}

Here, Takako introduces writing as a pedagogical strategy for facing the potentially disturbing nature of the curriculum and the possible flight responses it may generate. The writer's stance requires that an object be contemplated, distanced, thought and written. We conclude the conversation with a question about what Takako wants her students to carry forward from her classroom into their lives after the university: 'Have an infinite imagination. To imagine, put yourself in somebody else's shoes, or just to be able to imagine what it's like to be (an)other.'

\section{Embracing liminality}

Solveig is a professor in her 40s who entered the field of Gender Studies by chance during her master's thesis. Her motivation for working in the field lies in the fact that she has the possibility to engage in questions with a high degree of relevance for contemporary society. Solveig says, 'I feel that both in research and teaching, you can actually make a difference, maybe not a huge one, but at least we are relatively free still to form the purpose of what we do, what we teach and how we teach.' The sense of freedom and excitement she expresses is also connected to the 'openness' of the field and the enjoyment of inhabiting an 'unstable place,' which she perceives as dynamic and full of shifting perspectives - unlike the field where she pursued her BA degree.

Solveig's sense of freedom extends to the ways in which she carries out her teaching and advising, not according to checklists and objectives but according to differences in individual students: Their aims, their academic level, their ease in the academy and how much she can 'push' them. There is a distinct 'caring' voice in Solveig's story that runs counter to neoliberal discourses of branding (Gender Studies as an 'unstable field' rather than a marketable identity), competition (attending to student insecurities and needs) and the achievement of 'excellence' (hacking the 'academic game' is sometimes necessary to carry out personally meaningful projects) in higher education:

They understand the academic game that we need to play, and, in my dream world, I would not have to put a letter grade on their work. I just hate the fact that you then have to stamp or 'freeze' the work, this moment in time, finalise it when we know they will continue to develop.

In line with a feminist ethics of care, she recounts how she privileges the relational dimension of her teaching and advising, not assuming that students have the same starting points:

You realise as you get to know the students that some of them really want more safety. Some of them need something that can be transformed easily into something that can be reflected in a job title. Personally, I wouldn't want that. [For] those who can handle it, I try to get them to 
appreciate inhabiting 'an unstable place,' being more comfortable with not always knowing where they are going... I think we deal a lot with this insecurity in the beginning and then we facilitate their landing in the thesis. As long as they own their own Master's project... it's challenging for us supervisors and teachers because we have to sort of accept that we cannot steer them. We have to read up and be able to follow a very broad range of projects, very diverse projects in fact. But I think that's also a good thing that they are actually given the opportunity to land their own idea. But it's a long process.

Throughout the conversation, I perceive an oscillation between the I/we, suggesting room for both individual practices and judgements, and a collective sense of shared purpose:

We only have two years with our students, but our students really notice that we do things differently [than in other departments at the university]. We give them two advisors, we attend to their anxieties and insecurities all while pushing those who can handle it. The thing I think students have a hard time with at first is that I - and I think most of my colleagues would agree - we acknowledge that we don't have all the answers. We don't know everything [laughs]. Then they come to feel more at home in this 'vulnerability,' seeing each other as co-researchers rather than teacher/student.

Solveig's story establishes the contours of her identity with a distinctly feminist voice with its references to care, co-production and the destabilisation of the student/teacher hierarchy. She does not explicitly mention her strategies or those of her colleagues as belonging to 'feminist pedagogy,' but at the very least, her identity as a teacher emerges against an institutional context that does not place value on notions like 'trust,' which she sees as essential to the completion of an MA thesis:

As long as [the students] trust that [the faculty] can oversee it in a way that makes them comfortable. And as long as we are not expecting them to have everything settled in advance. I think that's also part of what's going on now in the second semester when they start developing their Master's project. It's a lot of active work from our side, I think, in making them understand that now we're not assessing your work. It's a work-in- progress which forms a tool for collaboration - that's new for some of them also.

\section{Finding a home in activism}

The next story is told by Astrid, a junior professor who, like Noriko, spent time abroad before returning to Norway. She sees herself has a highly 
committed feminist academic who is part of a research group on racism. Astrid's approach to teaching is grounded in an awareness, like Takako's, that Gender Studies asks students to confront uncomfortable realities about themselves, their families and the society in which they live and will develop their careers. She, too, finds that this can be problematic in classroom practice. Astrid started out by stating her own relationship to feminism:

I had some very solidarity-based idea[s] about feminism as being relevant outside of myself; it felt like it fit into this idea of me wanting to save the world. Then after taking classes [abroad], it all became very personal for me. I think they used to talk about Gender Studies as putting on a whole new way of seeing the world - a new pair of glasses that you can never ever take off again, even to watch movies.

Astrid explains that her initial entry into feminism was motivated by the material conditions, injustices and inequalities that she saw operating outside her home country. Later she had the experience of being both a student and teacher in the global south where she began to deeply question the (theoretical) centrality of Western feminism, claiming 'it all of the sudden became very personal for me.' By drawing from codes of social justice ('solidarity' and 'saving the world'), Astrid recognises the potential in feminism to work to solve societal problems. At the same time, she sees the development of feminist insight as irreversible. She continues to narrate her own coming into the discipline in an introspective voice using the metaphor of 'finding a home':

I had this idea of myself being a feminist academic with no disciplinary home, and then working outside Gender Studies you realise that people [in the academy/university] invest great meaning in the theories and methods you use and how you identify yourself. What's unique in Gender Studies is the possibility of finding a home.

Astrid sets her first-person feminist narrative against university departments that are perceived as operating according to a different set of values and established practices. By suggesting that an identification with particular theories and methods is a key part of academic life elsewhere outside of Gender Studies, Astrid is carving out a unique space for an interdisciplinary 'home' for Gender Studies and feminist academics. She explains this further, switching to a collective 'we':

The idea of having a home. It's like a collection of people who come from many different places but who aren't puritan about one's disciplinary 'traditions.' We're doing this interdisciplinary work and 
it's overtly political and we want to change something. There's something wrong in the world and we want to do something about it.

Astrid's story about what she is trying to accomplish in the classroom points to the fact that she desires a politically engaged disciplinary home. Her story resonates with Noriko's story of acquiring a novel means to understand one's own life. Both found that the lens of gender relations helped make sense of their lives up to that point.

We get young adults to take experiences that they have and extrapolate [from] them, abstract them and say there is something in the world, a different way of speaking about these experiences that isn't just about me and my relationship to another person or my family. To theorise injustice, I guess.

When I asked Astrid about her students in Gender Studies, she was quick to point out their ability to 'speak the language' and do things in an expected academic manner:

I meet these students that are theoretically fluent - they can speak the language, they can do the things and say the things and then when I push them on applying it to something that is proximal to themselves or their own communities, they can't. It falls apart. I'm currently at this stage where I'm saying, 'What do I do?'

Her story's activist voice makes salient the difference between theoretical understandings that allow students to discuss and manipulate ideas at a safe distance as opposed to the real-world confrontation of privilege or injustice. Her question about how she can manage to get students to examine issues that concern them directly is met with the rhetorical question, 'What do I do?' that doesn't seem to have an immediate or obvious answer. The next part of her story suggests that to a certain extent, she expects Gender Studies education to be difficult since the field should respect certain values. This requires an authoritative presence:

In the classroom, I'm strict about what you can say and what you cannot say, and I'll respond quickly if something is said that I don't think is ok [e.g. comments that marginalised students might find offensive]. Part of it is control, but there is also something...I don't think we should be comfortable. I know that we are working with things that are personal and we have to dig in our own lives, our own families and histories, our own bodies and our own minds and sexualities. That stuff is hard. That's one way that I think the feminisms we have in our classrooms should be hard, the learning that we want to happen. But it should also be hard in terms of confronting one's own privilege. 
The questions and difficulties that Astrid's activist voice raises are not connected to specific ways of approaching students beyond confrontation. Elsewhere in the interview, Astrid says she accepts that students will sometimes leave her classroom angry or frustrated. Her story is narrated in the second-person ('what you can and cannot say'), which comes across as authoritative but also distances her from that position. The subsequent slippage to the first-person plural when she discusses comfort and feelings of safety suggests that she sees herself as part of this process as well. She speaks from a feminist voice when she talks about the necessity of confronting privilege, borrowing codes of struggle and confrontation from feminist discourse.

We do a lot of 'safe' teaching in Norway. I say 'safe' in my teaching portfolio, and I say that I want people to be 'safe' in my classroom, but I also want them to be feminist and anti-racist spaces that aren't safe for privilege. In retrospect I can say that when I was uncomfortable, I learned. For me and people like me in that classroom, we shouldn't be safe. We are safe everywhere else. It sucks to be a woman sometimes, but when you are a (...) woman in Norway, you are mostly safe [from harm] and you benefit from diversity and gender balance projects. If I'm not safe in my own classroom, if I go out feeling uncomfortable, that's ok.

Astrid introduces the notion of safety by using vocabulary from the field of teaching and learning. While, on the one hand, she recognises that 'safe' is a buzz word in the discourse of teaching and learning, on the other, she states that such safety should not be extended to 'privilege.' She recognises the need from an institutional standpoint to demonstrate that her classroom is 'safe,' but she suggests that the concept cannot hold all possible configurations of protection simultaneously. In a moment of shifting subject positions, Astrid rationalises the construction of a potentially unsafe classroom as a tool to destabilise privilege from feminist and anti-racist points of view. What is interesting is the way that she sees a lack of safety being extended to her own self as the teacher of such a classroom.

\section{Gender studies educators: Feminist values and unbound learning spaces}

The four educator narratives presented here show that feminist values substantially inform the ways in which Noriko, Takako, Astrid and Solveig position themselves in their Gender Studies classrooms and make sense of their identity as educators. One of the most striking aspects of the stories concerns the storytellers' unbound notions of learning space. There is no mention of lecture hall or physical classroom space. The student's own self becomes one of the primary entry points into learning processes. Noriko uses her own life experiences, which she brings to life in story form (as 
opposed to using 'dry facts' from textbooks), to illustrate the relevance of gender research and provide possible points of connection to her female students' own lives. She also finds validation in making space for a motherly voice within the university - perhaps due to the unique context of a women's university - that responds with care to her students' dilemmas and problems outside the classroom. In Takako's story, she defends a pedagogical practice grounded in defamiliarisation techniques, but claims that such strategies depend on a sensitivity for students' emotional thresholds. Astrid's activist voice describes her attempts to politicise the classroom space and acknowledges the difficulties in doing so. Finally, Solveig's story represents a clear recognition of Gender Studies as an open field where teaching and advising are best carried out, in line with feminist alternatives to neoliberal thought (see, e.g., Connell, 2019), with care, responsiveness and vulnerability that help students develop a researcher identity.

The four educators presented here position themselves as feminists in that their pedagogical practices deviate from what can be considered the neoliberal 'norm' in higher education. None of them clearly mention 'feminist pedagogy' as an explicit influence, but this may be due to the absence of feminist and critical pedagogies from teacher training programs or to different cultural meanings attached to 'feminism.' 'Feminist pedagogy,' a term that can be traced back to the 1980s and early 1990s, reflects the claim that Women's and Gender Studies classrooms represent an exception to 'traditional' 3 ways of teaching. In Norway, the term 'feminist pedagogy' has not been as widely used as in the Anglo-American context to describe the praxis of feminist educators. This may be due to the fact that what is recognized as 'feminist' doesn't find a similar contrast in the Norwegian education system which has long traditions emphasizing gender equality and the value of 'sameness.' It may also be related to the visible presence and acceptance of academic feminism in Norway.

The idea of 'feminist pedagogy' also suggests that feminist values can open up for novel ways of teaching in line with 'what' we teach in Women's and Gender Studies (hooks, 1994). It is not clear, however, the extent to which these are individual strategies informed by the teacher's own disciplinary background and previous education experiences or whether there is some common ground to be discerned.

One might argue that it is risky to use the term 'feminist pedagogy' in a transnational study, given that the concept is not explicitly used in either Japan or Norway, nor is it covered in university pedagogical training programmes. There has even been significant resistance as to the possibility of feminist pedagogy in Gender Studies departments as they exist today in Japanese higher education, and Ueno (1999) warns that 'educating in a feminist way is not the same as educating in feminist theory':

[I]t has not always been easy even for many liberal educators to make visible and explicitly problematise the gender norms that pervade the 
reality of 'school,' a hierarchical space. In any case, it is a contradictory practice for teachers, who are in absolute power, to educate for 'liberation' in a system where [students] cannot choose [what constitutes] 'school,' 'classroom,' or 'homeroom.' (p. 84)

Ueno goes on to show the ever-widening divide at the turn of the 21st century between grassroots women's movements, which took as their point of departure the experiences of everyday women, and academic Women's Studies: 'Women's Studies can no longer start with a simple "let's talk about our experiences." [But] [w]e have to start by learning the language of experience.... In a sense, people without experience to refer to have entered Women's Studies' (p. 86). In this way, an authentic feminist pedagogy, with its consciousness-raising and analysis of women's lived experiences, is more at home among more democratic grassroots movements than it is in higher education.

In contexts where feminist pedagogy has been applied, educators have used it as a tool to raise consciousness about the ways in which inequalities are reflected and reproduced in educational settings and institutions themselves. Feminist educators often try to open up an alternative classroom space to counter the 'messages [that] are relayed to students about the relative power positions of different groups and individuals; and about the subjects and aspects of those subjects which are deemed appropriate for them to study' (Murphy, 2008, p. 28). Further, feminist pedagogy at a basic level promotes an awareness of social axes of difference (e.g., race, class, sexuality and ability) and the ways in which they structure individual experiences and opportunities in higher education. Murphy (2008) points out some of feminist pedagogy's key features ${ }^{4}$ that emerge in the research literature: Breakdown of traditional classroom hierarchies (destabilisation of teacher/student binary), focus on student transformation, development of a critical consciousness, awareness of the relationship between ideology, culture, power and subjectivity, classroom conceptualised as a political space with power relations that reflect those of the society at large, awareness of implicit learning about gender that takes place outside the classroom, democratisation and student voice (p. 93). In addition to this list, we might add: A valuing of the relational dimensions of teaching (Hooks, 1994), a recognition of the politics of knowledge production in higher education, and an intersectional approach to understanding genderbased oppression. In Hooks' (1994) view, it is an individual educator's task to reflect on and develop a teaching practice that brings in any combination of these elements, while remaining open to others.

These stories are to some degree individual (based on educator's own lived experiences) and field-specific (related to educator's academic specialisation) but do not reflect strong cultural distinctions. On that account, the stories provide a basis for future research. Given the individualised nature of the stories, more research is needed to examine the extent to 
which a transnational 'we' might be possible, and how such collective strategies might be linked to learning objectives and assessment. Setting these stories in dialogue through dialogical narrative analysis allows me to present these teachers as 'unfinalized' (Frank, 2005, p. 966) and to conclude with the certainty that making these stories accessible to Gender Studies colleagues and students will ensure that they continue to take form.

\section{Notes}

1 A literature search in the database Scopus on English language publications containing the keywords 'pedagogy' and 'higher education' shows an increase from the occasional one or two entries per year in the 1980 s to a high of over 700 entries in 2020.

2 Ueno points out that the overarching goal of professionalization has led to women's studies being open to male scholars who are (more) often able to meet the unquestioned criteria of 'excellence.'

3 What is meant by 'traditional' ways of teaching remains to be explored.

4 The starting point for this enumeration is Murphy, 2008, p. 93.

\section{References}

Bruner, J.S. (2003). Making stories: Law, literature, life. Harvard University Press. Connell, R. (2019). The good university. What universities actually do and why it's time for radical change. ZED Books.

Chick, N. L., Haynie, A., \& Gurung, R. A. R. (2012). Exploring more signature pedagogies: Approaches to teaching disciplinary habits of mind. Stylus Publishing.

Frank, A.W. (2005). What is dialogical research, and why should we do it? Qualitative Health Research, 15(7), 964-974.

Frank, A.W. (2012). Practicing dialogical narrative analysis. In Holstein, J.A., \& Gubrium, J.F. (Eds.), Varieties of narrative analysis (33-52). SAGE.

Freire, P. (1970). Pedagogy of the oppressed. The Seabury Press.

Hooks, B. (1994). Teaching to transgress: Education as the practice of freedom. Routledge.

Land, R., Meyer, J. H. F., \& Smith, J. (2008). Threshold concepts within the disciplines. Sense Publishers.

Murphy, P. (2008). Defining Pedagogy. In Hall, K., Murphy, P., \& Soler, J. (Eds.). Pedagogy and practice: Culture and identities, 28-39. SAGE.

Schulman, L. (1987). Knowledge and teaching: Foundations of the new reform. Harvard Educational Review, 57(1), 1-21.

Stommel and Morris. (2018). An urgency of teachers: The work of critical digital pedagogy. Hybrid Pedagogy.

Ueno, C. (1999). Difficulties in feminist pedagogy. In Sato, M. et al. (Eds.). Gender and education. Seori-shobo. 


\title{
7 Making it in academia: A study of career narratives of men and women professors in Norway and Japan
}

\author{
Vivian Anette Lagesen, Guro Korsnes \\ Kristensen, Siri Øyslebø Sørensen, \\ and Derek Matsuda
}

\section{Inclusion into professorships}

Professorships are hard to achieve in most countries for both men and women due to a scarcity of permanent positions in academia (Fumasoli et al., 2015). Becoming a professor means entering the academic sphere and then competing for funding and positions to stay in often-precarious job situations for many years. What facilitates and/or hinders researchers' trajectories toward professorships? In this chapter we investigate how men and women professors in Norway and Japan account for their career trajectories with an emphasis on what has helped them persevere and manage to stay in academia. The aim is to contribute insights on what are important inclusion factors and whether, and if so, in what ways, these are gendered and contextual in becoming a professor in Norway and Japan.

Whereas increasing numbers of women are entering universities, the proportion of women in full professor positions has remained disproportionately low in most countries, including Norway and Japan. In Norway, women constitute $34 \%$ (Tungesvik, 2021) of all full professorships and, in Japan, only 10\% (Gender Equality Bureau Cabinet Office, 2015 , p. 87). Clearly, academic careers do not unfold in identical manners across national contexts, and individuals are not independent from local, institutional and national contexts (Le Feuvre et al., 2019). Thus, it is interesting to explore factors that are emphasised by men and women professors as important for becoming professors in two contexts as different as Norway and Japan. Since there are clearly many potential factors playing in, our study is predominantly an explorative one where we ask: What do men and women professors consider the most important factors for entering and managing their career in academia?

We shall start by consulting literature on what has been found to be important for entering and sustaining careers in academia. A substantial part of this literature is from a Western context. However, we shall also outline the main features of the national contexts for Norway and Japan for making an academic career. Then we present our analysis of the empirical 
data. In the discussion, we reflect on how the inclusion factors that were emphasised in our interviewees' accounts should be understood in a larger societal and scholarly perspective.

\section{Research on entering and sustaining academic careers}

Early efforts to study professors (who were usually men) focused on psychosocial aspects, like early childhood experiences, background variables and personality traits (Lindholm, 2004). Later, studies of professor careers (still usually of men) have pursued a class perspective emphasising cultural and social capital (Bourdieu, 1988). Another strand of studies is concerned with social cognitive factors, such as the combination of self-efficacy and expectations of outcome and goals (Lent et al., 1994). For example, professors in Lindholm's study (2004) from the US spoke of a 'true calling' and a 'match' between them and academia (pp. 611-24). Studies of academics have often found that a passion for academic work, an appreciation for being in an academic job and flexibility are important drivers for staying in academia. In Riordan's (2011) study of senior academics from six different countries, opportunities for individual expression and autonomy were emphasised. According to Cannizzo (2018), discourses of 'passionate' labour, self-authenticity and personal freedom are central to how academics talk about and govern their work.

Another factor often stressed as important for entering and remaining in academia is cultural and social capital (Bourdieu, 1988), the former particularly in the form of an academic family background. A study from the Netherlands (Van Balen et al., 2012) found that social capital (via mentorship and network) was more important academic background for whether talented academics stayed or left academia. Social capital may include social networks, but also people who help and support to remain and advance in academia (Van den Brink \& Benschop, 2014; Etzkowitz et al., 2000; Heffernan, 2020). Mentorship and supervisors have been found to be of crucial importance for academic advancement (Blackburn et al., 1981; Van Balen et al., 2012). Another aspect often found to increase the probability of succeeding in academia is a willingness to be geographically mobile, due to increased competition and internationalisation (Kim, 2017; Ortlieb \& Weiss, 2018). Being transnational has also been seen as constitutive for academic identities. Nonaka (2020) has reflected on how her transnational research career influenced her identity as a Japanese woman professor and helped her advance. A study by Cohen et al. (2020) from New Zealand has shown how discourses of academic mobility were considered essential to academic work but that heteronormative discourses of motherhood produce gender inequities in academic mobility.

While most studies on inclusion in academic career inclusion in the Western context have comprised predominantly studies of men, studies of women in academia have mainly focused on exclusion (also in a Western 
context). One argument is that academia is a 'greedy' line of work which makes for a difficult work-life balance because of traditional household divisions and caring responsibilities (Ivancheva et al., 2019; SalminenKarlsson et al., 2018; Ward \& Wolf-Wendel, 2012; Ylijoki, 2013). Family situations and caring responsibilities have been seen as an important reason for why women opt out of academia (Acker \& Armenti 2004; Van Anders, 2004). Women who remain in academia have been found to struggle with parental guilt and a sense of work-life imbalance (Castaneda \& Isgro, 2013; Dubois-Shaik \& Fusulier, 2017; Ghodsee \& Connelly, 2011). However, studies suggest that having children does not seem to affect scientific output as such (Aiston \& Jung, 2015; Heijstra et al., 2015). This is also the case in Norway, where the combination of an academic career and childcare has been more common than in other countries (Vabø et al., 2014). Here, a study showed that having children has not seemingly affected scientific output for Norwegian women academics, while it had a positive effect on the scientific output for Norwegian men (Hovdhaugen et al., 2004).

Much literature has focused on how many women have been and continue to be disadvantaged through institutional, cultural and organisational forces at work in academic settings (see, e.g., Fox et al., 2017). Gender discrimination, sexual harassment and sexism have been seen to impact women's careers, and the term 'chilly climate' has been used to describe the alienation and isolation reported by women (Bevan \& Learmonth, 2012; Britton, 2017; Savigny, 2014) - not only on the basis of their gender, but also their class, race and ethnicity (Essed, 2004; Gutierrez et al., 2012; Ostrove et al., 2011; Stewart \& Dottolo, 2005). Also, the notion of 'excellence' and what it means to be a 'good academic' have been found to be masculine constructs (Lund, 2020a, 2020b).

Finally, a gendered division of work impedes women's careers in academia. Women spend more time on non-meriting tasks, such as teaching administration and service work, also referred to as the 'academic housework' (Angervall \& Beach, 2017; McFarlane \& Burg, 2019). Guarino and Borden (2017) have found that women faculty perform significantly more service work than men, controlling for rank, race/ethnicity and field or department.

In Japan, a study found that even though work-life balance created stress among men and women faculty because research was often disrupted by life events, job satisfaction was higher than in other types of work (Fuchigami \& Sugita, 2021). Yet another study found that taking childfcare leave did not diminish work performance (Takeishi, 2008). However, there is a need for more qualitative studies on academic life in Japan in general (Poole, 2010), especially with a gender perspective (Yukawa et al., 2019). In Norway, women also struggle with combining parenthood with academic jobs because of increasing workload (Thun, 2019). Women are also less able to fulfil the criteria for being a 'good academic,' because they are doing disproportionally more carework in the home and academic housework 
than men (Lund, 2020). Moreover, 'excellence' is still a gendered concept in Norwegian academia, where traditionally men-dominated disciplines are more frequently associated with excellency (Henningsen \& Liestøl, 2013).

To sum up, there has been many studies showing how women are excluded from academic careers in a multitude of ways. However, there have also been policy efforts aimed at getting more women to become professors. In the following text, we will outline some of the policy work that has taken place with regard to gender balance in professorial positions in Norway and Japan.

\section{Gender balance and academic career trajectories in Norway and Japan}

According to Husu (2015), Norway has had the most comprehensive and longstanding effort to improve gender equality in academia within Scandinavia. However, the share of women in professorial positions (as of 2021) is 34\%. The Humanities and Social Sciences have a better gender balance than STEM disciplines, even if there are large variations in the proportion of women professors between disciplines in the STEM fields and also within disciplines in the Humanities and Social Sciences (Sørensen \& Lagesen, submitted 2021).

In Japan, the percentage of women full professors is only $10.8 \%$, and even fewer are leaders in academia. The Japan Association of National Universities has established a Gender Equality Headquarters at each national university, with the goal to reduce gender imbalance in various areas. Also, a program to support research activities of women researchers was launched in 2013. More than $20 \%$ of women professors are working in the fields of the Humanities and Fine Arts and fewer than 5\% in the fields of Science and Engineering (Gender Equality Bureau Cabinet Office, 2015).

The typical academic career path in Norway goes from PhD to postdoctoral researcher to associate professor, eventually ending in a full professor position. Since 1993, Norwegian associate professors have been not only able to advance to professorial status by applying for vacant professor positions, but also by applying for a promotion to become professor on the basis of their research competence (Olsen et al., 2005).

There is also a third way - by applying for a vacant professorship in an open competition, being found competent but not the best qualified by the evaluation committee and then asking to be promoted to full professor in your own institution. Applying for promotion is now a more common strategy to become professor in Norway than applying for a vacant professorship (Kyvik, 2015). Due to having several pathways, there is a higher share of professors in Norway than in most other countries, and $40 \%$ of Norwegian faculty has a full professor position.

In Japan, there are also several ways to become a full professor. However, the most common way is that one applies to a tenure track position, which normally starts at the assistant professor or lecturer level. Based on the number of publications and years of teaching experience, the 
universities decide upon promotion to professor. Unlike in Norway where criteria for promotion are subject to national regulations, each Japanese university has its own criteria for promotion (Poole, 2010).

Support systems for women academics in Japan who are raising children differ widely by institution and the woman's professional status. In Japan, women are in general expected to care for their own children, as well as for other family members, such as the elderly. Full-time academic staff can get financial support for hiring babysitters or nursery teachers. They normally also have flexible working hours and can even work from home at times. However, this benefit does not typically extend to part-time academic staff. Also, in Japan a study found that having children did not statistically affect scientific output for women academics (Takeishi, 2008).

In Norway, the situation is different in that childcare facilities are more easily available for all, and parental leave schemes are extensive and designed to promote gender equality (Kvande \& Brandth, 2019). Having children while pursuing an academic career is also more common in Norway, compared to other countries (Vabø et al., 2014).

Even so, recent research in both contexts has also found that women academics struggle more with having children due to increased workload in academia (Thun, 2019), and that life-events create work-life balance stress for faculty (Fuchigami \& Sugita, 2021). Thus, it is pertinent to further explore what women and also men professors in the two contexts consider important for sustaining their academic careers.

\section{Data and methods}

We did in-depth qualitative interviews with 28 academics: 13 professors in Japan ( 8 women and 5 men) and 15 in Norway (10 women and 5 men). All interviewees were between 35 and 70 years old, with the majority being between 50 and 60. Interviews with professors in Norway were conducted in 2017 and 2018 as part of a larger research project aimed to improve gender balance among professors at a Norwegian university. The interviews with professors in Japan were conducted in 2020, as a spin off from the first project; it was made possible through the INTPART-funded research collaboration with Ochanomizu Women's University. The Norwegian professors were from the same university, while the professors working in Japan were recruited from eight different universities. These universities are located in different parts of Japan and cover a wide range of academic profiles. Interviewees in both countries represented different disciplines and research areas, and most of them worked in departments struggling with gender imbalance among full professors. Norwegian professors were recruited randomly and approached directly via e-mail. The Japanese professors were recruited by the assistance of mediators, who suggested potential participants and made the first-contact approaches. All participants were informed that the interview was part of a research project on gender balance. Almost all the professors we contacted accepted the invitation to participate. 
The interviews with the professors in Norway were done face to face by Norwegian researchers in Norwegian, the mother tongue of the interviewer and most of the interviewees. The interviews with the professors in Japan were done by the same Norwegian interviewers and conducted in English, a foreign language for both interviewers and interviewees. In most cases, the interview guide was shared with the interviewees beforehand. This made it possible for the interviewees to prepare and thus also helped reduce the language barriers. Due to the COVID-19 pandemic, interviews with Japanese professors were conducted online via zoom.

The interviews lasted from 30 to 60 minutes. We began by asking the interviewees to give an account of their personal career trajectories, and then we followed up with questions about how they perceived inclusion in this process. The questions were open-ended. All interviews were transcribed verbatim. In the next section, we explore what kind of inclusion the professors emphasised in their accounts of career trajectories. We start by analysing the main features of inclusion factors that were brought forward by our interviewees in both Norway and Japan. Each interview excerpt is cited with the interviewee's country and participant number. Then we will focus on what were seen as the greatest challenges. At the end of each section, we will discuss how our findings relate to the previous literature. In the last section, we offer some overall reflections on our findings.

\section{Passion, hard work and personal sacrifices}

Similar to much previous research, many of our interviewees in both Norway and Japan described the path to professorship as one of dedication and passion for academic work, as well as a willingness and ability to work hard and make what they saw as the necessary sacrifices for staying in academia. Such sacrifices could typically be long working hours and hence less time with family and friends, and/or long periods of hard and stressful work. For example, when asked to characterise her academic journey, a woman professor in Japan formulated it this way: 'It was very challenging. It was never easy. It took a long time and along the way I had to make a lot of tough priorities' (JAPAN 8).

However, such stories about hard work were also followed by engaged talk about research fields and teaching activities. A man professor put it like this: 'My career is exciting and fun!'. When he was asked directly if it had not also included 'hard work and efforts', he followed up with this answer:

Yes, effort is always important. We should work hard, but it's quite natural. I would say it's also my father's influence. I would see my father work hard at home. My friends in university also work at home hard. I think it is quite natural that I should work hard. It's no stress for me. (JAPAN 2) 
This emphasis on hard work was also highly present in the interviews with the Norwegian professors, both women and men. A telling example is to be found in the interview with a man professor in his early 60s:

The road to becoming professor has been cumbersome, tough and hard. Yes. And exhausting. But I have been so dedicated as a scholar, so I will claim it was worth it. But I am not sure I would have done it again. (NORWAY 3)

This quote clearly illustrates how academic work was considered rewarding, and so it compensated for the cumbersomeness of the process of becoming professor. But the quote also shows a good deal of ambivalence, emphasizing how hard such a process could be. Sacrifices made in order to get or keep a job in academia was also mentioned and were sometimes quite considerable. One international woman professor living in Norway gave birth to her children in another country, before she got a job in Norway. Since her children still lived there, she had to commute and spend much time away from her family. Still, she found the sacrifice worthwhile, because she loved the job:

I miss my children and my family very much. I find it difficult to leave when I am there. But so far it is going well, and I have a fantastic job. I enjoy the job immensely! But I do long for home sometimes (...) but thriving in the job is an extremely important factor. (NORWAY 14)

There were also other interviewees in the same situation, having chosen to work far away from their families. Others travelled together with family. Our data illustrated well how important it was to be geographically mobile to secure employment in academia. However, sometimes the decision to move was for scholarly reasons, such as being with the most relevant research group and/or being able to pursue their own research interests. Thus, working in an academic job was considered extremely valuable and enjoyable by many of our interviewees, both in Japan and Norway, and considered worth quite substantial sacrifices by many.

We did not find substantial differences between Japanese and Norwegian professors with regard to this strong dedication to their academic work, which was emphasised by most as a major motivation for their careers. Nor were there differences between men and women professors in this matter. Thus, passion and the attractiveness of a permanent job in academia are important inclusion qualities. In the next section, we will discuss what kind of supported inclusion was experienced by our interviewees. 


\section{Supported inclusion}

Many of our interviewees talked about how other people had been important for supporting them in their career. Many mentioned mentors or role models that either had inspired or encouraged them to pursue an academic career, either by evoking an interest for a particular topic or a research area, or by showing that barriers can be pushed. In the interviews with Japanese professors, this inspirational role was in quite a few cases played by parents or other family members who were academics or professors themselves. This opened a door to the academic world by showing that it is possible to pursue this line of work. This represents the cultural capital argued by Bourdieu (1988) The role of a parent in motivating their child to take up an academic career can be exemplified in the following interview extract with a professor in his late 40s explaining why he had chosen academia:

It's an important question! Maybe it's the influence of my father. My father looks quite happy because he worked with his students and got an exciting result. He was always excited to talk about the results that students gave him. (...) So, maybe when I was 10 years old, I said I will work in university someday. (JAPAN 2)

This way of framing the choice as inspired by a parent, usually a father, was more prominent in the interviews with Japanese professors than among our Norwegian interviewees. A Norwegian professor shared that seeing his father with the status of professor made the job seem more normal and less daunting:

One thing I have reflected on is that I have never really had a lot of respect for professors and other academics. When my father could be a professor, anybody could [laughs]. It wasn't something special, it was just a job and an okay one. (NORWAY 7)

We see that both interviewees presented their father's role as important for demonstrating that a professorial position is attractive but also obtainable. Having such a role model instilled motivation and confidence to embark on an academic career path.

Women professors often mentioned women in academia as role models who had been important for them in pursuing an academic career:

An older woman professor has been an important role model for me. She has three children, husband and a home, and then I thought, okay, it is possible. (NORWAY 1).

What was common in the accounts of women professors in Norway was that they saw it was possible to combine a job as a professor with having a family and caring for children. 


\section{Vivian Anette Lagesen et al.}

Many of our interviewees in both Norway and Japan talked about important mentors and supervisors who had guided them into an academic career by directly or indirectly giving them possibilities for career advancement. For many, this role was typically ascribed to their supervisor:

Interviewer: How did you succeed?

Professor: I have a very good mentor, [who is] a very good person, adviser and supervisor at this university. He was very supportive. I think that is an important reason (...) He gave me many chances to get positions and encouraged me. (...) He gave me possibilities at [my current] university, which was important for me. (JAPAN 1)

We see that support from a mentor was fundamental in this professor's career, and he credited much of his possibilities to have an academic career to this mentor. This was a very common narrative among the Japanese and Norwegian professors we interviewed, no matter their gender. Similarly, those who had not had such a mentor were often stressing this, indicating that having a mentor to guide and help a young scholar was perceived as crucial. A woman professor in Norway explained,

After my PhD, I have had to make it on my own, always. I believe I have been pretty strong, because I haven't had anyone to mentor me or to consult. I have, sort of, had to do everything myself. And it turned out well. (NORWAY 5)

While not having a mentor was considered a disadvantage, it also instilled a certain self-efficacy as well as pride in having become a 'self-made' professor. Most women professors in Norway, and to a lesser extent in Japan, talked about how they had been supported, and surprisingly few talked about overt gender discrimination as a pressing issue. One exception was a woman professor in Japan who had changed her field of research because of a lack of support from the men professors supervising her work. Entering a new field with a new mentor, who was a woman, made it possible for her to have an academic career:

The most crucial moment was deciding to change my specialties. It was my decision, but I think it was planned by men professors. So, the men professors they didn't teach me well, and I felt they were ignoring me. (...) When I changed my specialty, my mentor was a woman professor. (...) Women professors supported me a lot. I was helped by them. One of them who accepted me became the main judge in my doctoral thesis. I think they saved me in the academic journey. (JAPAN 3) 
These narratives demonstrate how mentors and role models played a crucial part in professors' careers. Others were also identified as important supporters along the way, such as colleagues, friends and, most importantly, family members. This was particularly evident in women professors' accounts, both in the Japanese and the Norwegian context. Support related to childcare was emphasised by most women professors, but by very few of the men professors.

Women professors in Norway often emphasised their partners as an important support, particularly in regard to having an equal division of domestic labour. Whether the interviewees found combining an academic career with parenthood to be stressful or not depended on whether their partners took on a fair share of the work:

I have had good support at home. An encouraging man and unproblematic children so-to-speak. So, there has not been heavy burdens there (NORWAY 9)

Another interviewee described this successful home dynamic as having a functional 'ground control' (NORWAY 8).

Having a reliable support system at home was not the only contextdependent difference in the data between women professors. Norwegian women professors often mentioned women-centred collectives and networks as an important source of motivation and support in their academic career. Encouragement and 'push' from leaders and supervisors to promote or stay in academia was frequently mentioned, as well as being awarded help and support by policy efforts, such as extra funding or extra leave to qualify for professorship. These kinds of effort were not mentioned often by women professors in Japan. But many mentioned their mothers as an important support, who had encouraged and supported them in their choices and their path to become a professor.

\section{Work-life balance}

As discussed in the theory section, women researchers often experience 'parental guilt' and a troublesome work-life balance. The experience of feeling torn between competing obligations at work and home, and the feelings of inadequacy this created, has been found among women across national settings (Acker and Armenti, 2004; Dickson, 2019; Ward \& WolfWendel, 2004). How did Norwegian and Japanese professors organise their personal and professional lives, and how did they make sense of their own time management and priorities in this regard? Were there gendered or contextual differences in how this was narrated?

Negotiations of time and priorities seemed to be different between men and women professors in both the Japanese and Norwegian contexts. In both contexts, the topic of work-life balance was negotiated with regard to 


\section{Vivian Anette Lagesen et al.}

societal gender norms on the one hand, and personal desires and lifechoices on the other hand. Pursuing an academic career while raising a family was considered challenging, but doable. Women professors with children in our sample described feeling conflicted about how best to divide their time and attention. A quote from a senior Norwegian woman professor illustrates this conflict well:

Really, my glorious years were from 1988 to ' 97 . In that period, I worked a lot, and I achieved a lot. Those ten years, without children, and few commitments, when my colleagues were my friends - during those years, I got a lot of work done. But, then, after ' 97 , the years with young children, was more like [being] in a fog. (NORWAY 1)

A Japanese woman professor similarly described her experience of raising young children while trying to maintain her academic work. When asked about crucial moments in her career, she replied,

I had to write papers at the same time [that I was immersed in] childbearing. When I was 30, I had to do two things: Writing papers and caring for my baby. It was a very tough time for me because I wanted to spend much more time with the child, but every day I thought, 'I have to write a paper, I have to do research.' (JAPAN 9)

In both Japan and Norway, the timing of having children in relation to career timing was portrayed as crucial. However, particularly in the Norwegian context, there were also many stories about combining work and family without much conflict. Some told how they combined high ambition research with motherhood:

The day I defended my PhD, I was pregnant. (...) After I had my first child, it only took a month before she was with me in the lab. With my second child, it took a week before he was with me in the lab. (...) You had to be at the research front, you had to keep up. (NORWAY 4)

This professor described herself as being 'equally hungry for work as for family.' She did not see these desires as contradictory but framed the situation as a matter of practical arrangement. However, we also heard stories of women who chose to work $80 \%$ in order to prioritise the family, which meant their career had taken a longer time to develop than others':

When you wait so long to have children, it becomes more important than anything in the world. That has been my priority, and I did not care if anyone bypassed me. (NORWAY 6) 
The flexibility of academic work was also emphasised by the Japanese women professors as something that made it possible to combine work with family. One Japanese woman professor also had a more critical outlook, claiming that the long working hours were far from efficient:

Well, the good part is we can decide some part of the job by ourselves. Many professors stay until midnight, but I come back home. In my opinion, we need to work certain hours and then we have to have private lives to refresh ourselves. That will make our concentration in the work[place] better. (...) Traditionally in Japanese society, if you stay longer, even if you are just drinking coffee maybe, people think that you are a hard worker, even if you are not really working. (JAPAN 11)

Thus, prioritising private lives could also be seen as a way to enhance, rather than diminish, the quality of professional work.

A difference here between the two contexts was that work-life balance was considered easier in Norway than in Japan. While some Japanese women professors said they had chosen to refrain from having children in order to advance in their careers, none of the Norwegian women professors expressed anything of the same. Moreover, international women professors in Norway found it to be an apt location for having children because of the good work-life balance opportunities:

Both my husband and I got good positions, and then we decided to stay on. One of the reasons was the balance between work and family. If I compare with my friends in my home country, I see that the balance is much, much better here... We have never been struggling, we don't have to have grandparents and nannies [help us]. (NORWAY 10)

Women professors in Norway seemed to take it for granted that they would be able to combine family and an academic career, due to the welfare services provided and their expectations of relatively equal shared responsibility in home-making. Most assumed that their partners would contribute fairly equally to household-related work. Japanese women professors, on the other hand, emphasised the need for support from one's extended family in order to pursue an academic career, as most couples in Japan still do not have an equal work division at home. Nonetheless, the position of professor was considered better suited for combining work with family compared with other professions because of the relatively flexible working conditions. 


\section{Vivian Anette Lagesen et al.}

\section{Concluding reflections}

The main aim of this chapter is to contribute to existing literature on what it is that include men and women to work in academia as a professor, and gendered and contextual aspects of inclusion factors. We have sought to do so by exploring how men and women professors in Norway and Japan accounted for how they entered and manage to remain in a top-level job in academia. Professors of both genders in both contexts conveyed a strong motivation for and desire to stay in academia. To achieve their goal, they had worked hard and endured precarious job situations; some had also made quite substantial sacrifices. Many highlighted the same factors as important for surviving in academia which were mentors or supervisors who had provided help and were important role models. Some interviewees who had not had much support described their trajectory as difficult and challenging but still rewarding. Thus, a shared common inclusion factor was a strong motivation to stay in academia, and the willingness to make the necessary choices to be able to do so. In some cases, this meant making substantial sacrifices. But, many had received much support and help in order to succeed. Such help and support may to some extent be accidental, which explains how academics often emphasise this notion of 'luck' to succeed in academia (Lindholm, 2004; Loveday, 2018).

If we disregard idiosyncratic factors, gender and context made a difference, primarily in terms of domestic work division and childcare. Women professors with children and families reported that they faced greater challenges than their male counterparts. This was handled by adapting and taking advantage of the opportunities for help that existed, which could be family members or childcare services. The latter was more easily available in Norway than in Japan. Also, many women professors in Norway emphasised that they had partners who contributed significantly to housework. This was not mentioned by Japanese women professors. Nevertheless, academia was perceived to offer a flexibility that made work-life balance a bit easier compared to other workplaces for women professors in Japan. Childcare was rarely mentioned as an impediment by men professors in either context. Moreover, Norwegian professors - men and women - assumed that academic careers could be combined with having children, which was not taken for granted among Japanese professors. However, compared to previous literature, surprisingly few women professors talked about a 'chilly climate' or explicit gender discrimination. This is a fruitful and important starting point for further studies.

\section{References}

Acker, S., \& Armenti, C. (2004). Sleepless in academia. Gender and Education, 16(1), 3-24.

Aiston, S.J., \& Jung, J. (2015). Women academics and research productivity: An international comparison. Gender and Education, 27(3), 205-220. 
Angervall, P. and Beach, D. (2017). Dividing academic work: Gender and academic career at Swedish universities. Gender and Education. https://doi.org/10.1080/ 09540253.2017.1401047

Bevan, V. \& Learmonth, M. (2012). 'I wouldn't say it's sexism, except that ... It's all these little subtle things': Healthcare scientists' accounts of gender in healthcare science laboratories. Social Studies of Science, 43(1), 136-158.

Blackburn, R.T., Chapman, D.W., \& Cameron, S.M. (1981). 'Cloning' in academe: Mentorship and academic careers. Research in Higher Education, 15(4), 315-327.

Bourdieu, P. (1988). Homo academicus. Polity Press.

Britton, D.M. (2017). Beyond the chilly climate: The salience of gender in women's academic careers. Gender \& Society, 31(1), 5-27.

Cannizzo, F. (2018). 'You've got to love what you do': Academic labour in a culture of authenticity. The Sociological Review, 66(1), 91-106.

Castaneda, M., \& Isgro, K. (Eds.). (2013). Mothers in academia. Columbia University Press.

Cohen, S., Hanna, P., Higham, J., Hopkins, D., \& Orchiston, C. (2020). Gender discourses in academic mobility. Gender, Work \& Organization, 27(2), 149-165.

Dickson, M. (2019). Academic motherhood in the United Arab Emirates. Gender, Place \& Culture, 26(5), 719-739.

Dubois-Shaik, F., \& Fusulier, B. (2017). Understanding gender inequality and the role of work/family interface in contemporary academia: An introduction. European Educational Research Journal, 16(2-3), 99-105.

Essed, P. (2004). Cloning amongst professors: Normativities and imagined homogeneities. NORA-Nordic Journal of Feminist and Gender Research, 12(2), 113-122.

Etzkowitz, H., Kemelgor, C., \& Uzzi, B. (2000). Athena unbound: The advancement of women in science and technology. Cambridge University Press.

Fox, M.F., Whittington, K., \& Linkova, M. (2017). Gender, (in)equity, and the scientific workforce. InU. Felt, R. Fouche, C. Miller, \& L. Smith-Doerr (Eds.), Handbook of science and technology studies (pp. 701-731). The MIT Press.

Fuchigami, Y., \& Sugita, N. (2021). Actual conditions of work-life balance and required supports of improvement of work environment on faculty members. Information and Technology in Education and Learning, 44(4), 409-418.

Fumasoli, T., Goastellec, G., \& Kehm, B.M. (2015). Academic careers and work in Europe: Trends, challenges, perspectives. InT. Fumasoli, G.Goastellec, \& B.M. Kehm (Eds.), Academic work and careers in Europe: Trends, challenges, perspectives (pp. 201-214). Springer.

Gender Equality Bureau Cabinet Office. (2015). 'White Paper on Gender Equality 2015'. Cabinet Office, Government of Japan (p. 87).

Ghodsee, K., \& Connelly, R. (2011). Professor mommy: Finding work-family balance in Academia. Rowman \& Littlefield.

Guarino, C.M., \& Borden, V.M. (2017). Faculty service loads and gender: Are women taking care of the academic family? Research in Higher Education, 58(6), 672-694.

Gutierrez, G.M., Niemann, Y.F., Carmen, G.G., \& A.P. Harris (Eds.). (2012). Presumed incompetent: The intersections of race and class for women in academia. Utah State University Press. 
Heffernan, T. (2020): Academic networks and career trajectory: 'There's no career in academia without networks.' Higher Education Research \& Development. https://doi.org/10.1080/07294360.2020.1799948

Heijstra, T., Bjarnason, T., \& Rafnsdóttir, G.L. (2015). Predictors of gender inequalities in the rank of full professor. Scandinavian Journal of Educational Research, 59(2), 214-230.

Henningsen, I. \& Liestøl, K. (2013). Likestilling i akademia. Er eksellense for menn og grand challenges for kvinner? [Gender equality in academia. Is excellence for men and grand challenges for women?]. Tidsskrift for Kjønnsforskning, 37(3-4), 348-361.

Hovdhaugen, E., Kyvik, S. \& Olsen, T.B. (2004). Kvinner og menn - Like muligheter. Om kvinner og menns karriereveier i akademia [Women and men Equal opportunities. On women and men's career opportunities in academia] (Report No. 12 NIFU).

Husu, L. (2015). A comprehensive national approach to promote gender equality in science: The case of Norway. In W. Pearson, L.M. Frehill \& C. L. McNeely (Eds.), Advancing women in science: An international perspective (pp. 329-331). Springer.

Ivancheva, M., Lynch, K., \& Keating, K. (2019). Precarity, gender and care in the neoliberal academy. Gender, Work \& Organization, 26(4), 448-462.

Kim, T. (2017). Academic mobility, transnational identity capital, and stratification under conditions of academic capitalism. Higher Education, 73(6), 981-997.

Kvande, E., \& Brandth, B. (2019). Designing parental leave for fathers - Promoting gender equality in working life. International Journal of Sociology and Social Policy, 40(5-6), 465-477. https://doi.org/10.1108/IJSSP-05-2019-0098

Kyvik, S. (2015). The academic career system in Norway. In M. Yudkevich, P.G. Altbach, \& L.E. Rumbley (Eds.), Young faculty in the 21st century: International perspectives (pp. 173-200). SUNY Press.

Le Feuvre, N., Bataille, P., Kradolfer, S., Carral, M.R., \& Sautier, M. (2019). The gendered diversification of academic career paths in comparative perspective. In A. Murgia, \& B. Poggio (Eds.), Gender and precarious research careers: A comparative analysis (pp. 50-80). Routledge. https://doi.org/10.1038/s41467018-07034-y

Lent, S.W., Brown, S.D., \& Hackett, G. (1994). Toward a unifying social cognitive theory of career and academic interest, choice, and performance. Journal of Vocational Behavior, 45(1), 79-122.

Lindholm, J.A. (2004). Pathways to the professoriate: The role of self, others, and environment in shaping academic career aspirations. The Journal of Higher Education, 75(6), 603-635.

Loveday, V. (2018). Luck, chance, and happenstance? Perceptions of success and failure amongst fixed-term academic staff in UK higher education. The British Journal of Sociology, 69(3), 758-772.

Lund, R. (2020a). The social organisation of boasting in the neoliberal university. Gender and Education, 32(4), 466-485.

Lund, R. (2020b). Becoming a professor requires saying 'No': Merging equality and quality agendas in a Norwegian gender balance project. In H.L. Smith, C. Henry, H. Etzkowitz H, \& A. Poulovassilis (Eds.), Gender, science and innovation (pp. 35-57). Edward Elgar Publishing. https://doi.org/10.4337/9781786438973. 
McFarlane, B. and Burg, D. (2019). Women professors and the academic housework trap. Journal of Higher Education and Management, 41(3), 262-274, https://doi.org/10.1080/1360080X.2019.1589682

Nonaka, C. (2020). Transnational identity: The struggles of being and becoming a Japanese female professor in a neo-kokusaika phase of Japan. Research in Comparative and International Education, 15(3), 234-251. https://doi.org/10. 1177/1745499920946201

Olsen, T.B., Kyvik, S, \& Hovdhaugen, E (2005). The Promotion to Full Professor Through Competition or by Individual Competence? Tertiary Education and Management, 11(4), 299-316. doi: 10.1007/s11233-005-0981-6

Ortlieb, R., \& Weiss, S. (2018). What makes academic careers less insecure? The role of individual-level antecedents. Higher Education, 76(4), 571-587. https:// doi.org/10.1007/s10734-017-0226-x

Ostrove J., Stewart, A.J., \& N.L. Curtin (2011). Social class and belonging: Implications for graduate students' career aspirations. The Journal of Higher Education, 82(6), 748-774. https://doi.org/101080/00221546.2011.11777226

Poole, G.S. (2010). The Japanese professor: An ethnography of a university faculty. Brill.

Riordan, S. (2011). Paths to success in senior management. In B. Bagihole, \& K. White (Eds.), Gender, power and management (pp. 110-139). Palgrave Macmillan.

Salminen-Karlsson, M., Wolffram, A., \& Almgren, N. (2018). Excellence, masculinity and work-life balance in academia: Voices from researchers in Germany and Sweden. International Journal of Gender, Science and Technology, 10(1), 52-71.

Savigny, H. (2014). Women, know your limits: Cultural sexism in academia. Gender and Education, 26(7), 794-809.

Sørensen, K.H. \& Lagesen, V.A. (manuscript submitted for publication). Diverging diversity: The changing gender balances among university faculty.

Stewart A.J., \& Dottolo A.L. (2005) Socialization to the academy: Coping with competing social identities. In G. Downey, J.S. Eccles, \& C.M. Chatman (Eds.), Navigating the future: Social identity, coping, and life tasks (pp. 167-187). Russell Sage Foundation.

Takeishi, E. (2008). Conditions necessary for offering childcare leave without sacrificing workplace performance. Lifelong Learning and Career Studies, 5, 59-73.

Thun, C. (2019). Excellent and gender equal? Academic motherhood and 'gender blindness' in Norwegian academia. Gender, Work \& Organization, 27(2), 166-180. https://doi.org/101111/gwao.12368

Tungesvik, R. (Ed.) (2021). Tilstandsrapport for høyere utdanning 2021 [Report about higher education]. Report no. 7.

Vabø, A., Padilla-González, E., Waagene, E., \& Næss, T. (2014). Gender and faculty internationalization. In Huang F., Finkelstein M., Rostan M. (Eds.), The internationalization of the academy. changes, realities and prospects (pp. 183-205). Springer.

Van Anders, S.M. (2004). Why the academic pipeline leaks: Fewer men than women perceive barriers to becoming professors. Sex Roles, 51(9-10), 511-521. https:// doi.org/101007/s11199-004-5461-9

Van Balen, B., Van Arensbergen, P., Van Der Weijden, I., \& Van Den Besselaar, P. (2012). Determinants of success in academic careers. Higher Education Policy, 25(3), 313-334. https://doi.org/10.1057/hep.2012.14 


\section{Vivian Anette Lagesen et al.}

Van den Brink, M., \& Benschop, Y. (2014). Gender in academic networking: The role of gatekeepers in professorial recruitment. Journal of Management Studies, 51(3), 460-492. https://doi.org/101111/joms.12060

Ward, K., \& Wolf-Wendel, L. (2004). Academic motherhood: Managing complex roles in research universities. The Review of Higher Education, 27(2), 233-257.

Ward, K., \& Wolf-Wendel, L. (2012). Academic motherhood: How faculty manage work and family. Rutgers University Press.

Yukawa, Y., Sakanashi, J., \& Murasawa, M. (2019). The contributions and potentialities of the study of the academic profession in Japan. The Journal of Educational Sociology, 104, 81-104. https://doi.org/101177/1028315308330848

Ylijoki, O.H. (2013). Boundary-work between work and life in the high-speed university. Studies in Higher Education, 38(2), 242-255. https://doi.org/10.1080/ 03075079.2011.577524 
Part III

Media 


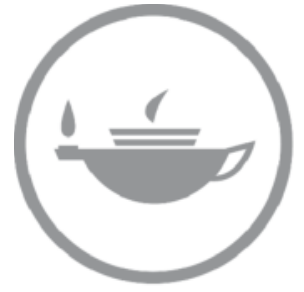

Taylor \& Francis Taylor \& Francis Group http://taylorandfrancis.com 


\title{
8 Masculinity in contemporary Viking and Samurai comedies: 'It's not really me, that fear-based leadership style stuff'
}

\author{
Jennifer Branlat and Priscilla Ringrose
}

\section{Living up to modern masculinities}

In this chapter, we examine contemporary TV comedies about Norwegian and Japanese manhood in crisis. Norsemen (original title: Vikingane; 2016) is a Norwegian comedy series about a group of vikings living in Southern Norway around the year 790 C.E. The series is a high-quality production with a rich visual texture that parodies the ultra-realistic diegetic worlds of more pretentious blockbusters, such as Vikings (2013-2020) and Game of Thrones (2011-2019). The characters are clad in period dress, with an emphasis on draping wool and well-worn leather. Norsemen was filmed at a location in a coastal village in Norway, and it was recorded simultaneously in both Norwegian and English-language versions by filming each scene twice. Its humour is delivered in a Monty Pythonesque deadpan style. The series premiered in Norway on the national TV channel NRK and was later aired on Netflix in both Norwegian and English. Samurai Shifters (original title: Hikkoshi Daimyo!, 2019) centres around a community of samurai living in the Himeji domain of southeast Japan in the 1680 s, during the Edo period. Released in 2019, the comedy features a star-studded cast, including the musician Gen Hoshino in the leading role. The film follows many of the codes and traditions of the familiar jidaigeki, or period drama, in its foregrounding of honour, sacrifice and sword-fighting. Although the jidaigeki genre influences the overall narrative structure, it is playfully ridiculed in farcical moments of subversion.

Norsemen and Samurai Shifters tell stories about the difficulties of living up to contemporary societal expectations concerning manhood. They give these stories a comic twist by transposing the characters back to a distant past - the Viking Age (800-1050) and the Edo period (1603-1867) - eras, which as represented in popular culture, are famously unconcerned about matters like gender equality, being a good partner and the equal sharing of domestic duties. The main characters of these comedies repeatedly find themselves in dilemmas that pit their millennial sensibilities against the values of the past: How can you be an effective leader when you are an introvert, bibliophile, recluse? How can you relocate an entire clan over a 


\section{4}

vast territory when you rarely leave your living quarters? Is it possible to be an intimidating warrior and still be sensitive enough to attend poetry readings with your wife? The protagonists perpetually and comically find themselves at odds with what society expects of them.

A brief look at the opening sequences shows how the films' creators frame the spectator's entry into the narrative space. In the opening sequence of the Norsemen, Arvid, the main character, is torn between his love of raiding and his desire to settle down. As his ship nears home, he confides in his chieftain superior:

Can't exactly say I'm looking forward to coming home now...My focus has always been on pillaging and ravaging and things like that, when all the other guys have settled down with wives, kids, farms and stuff. I'm feeling kind of alone here. (Helgaker \& Torgersen, 2016)

From Arvid's initial apprehension, the series proceeds with a satirical exploration of the unrealistic pressures to be the 'perfect man.' In a similar staging of masculinity and impossible expectations, Samurai Shifters opens with a hand drawn map that foregrounds the daunting task given to Katagiri, the unlikely 'shut in' samurai: Faced with limited time and budget, he is tasked with executing a master plan for the clan's distant relocation across land and water. As parodies or spoofs on the historical action drama, these narratives are less concerned with reproducing an accurate version of the past than they are with poking fun at the present.

In this context we understand film as a social practice that 'constructs narratives and meanings,' which enable us to 'locate evidence of the ways in which our culture makes sense of itself' (Turner, 2006, p. 3). Our decision to bring comedy into a discussion of masculinity reflects an attempt to liberate discussions of manhood from its polarising formats in media debates. We have also taken comedies from two different national contexts in the hopes that readers will come to see their common project: To defamiliarise contemporary societal expectations concerning masculinity. By taking the imperatives and pressures related to 'caring,' 'sensitive' manhood and staging them in a past dominated by representations of militaristic, hegemonic hierarchies - far from today's preoccupations with 'gender equality' or 'work-life balance' and 'caring fathers' - a comic effect is achieved. The comedy genre therefore allows us as spectators to step out of the realm of 'political correctness' operating in daily life and laugh at our own cultural attitudes, practices and their excesses. In this way, the process of defamiliarisation opens up a space between spectators and their own culture, a space in which reflection can occur in a playful manner. We ask: What dimensions of modern masculinities do these comedies explore? To what degree do these comedies uphold or challenge the prevailing social orders in Japan and Norway? Are there any similarities and differences that can be found in the representations of masculinity? 


\section{Theoretical framework}

Theories of humour and comedy have remained relatively stable over past decades, even as humour - most prominently over the past decade in the form of American satirical news programs - has come to the fore as an important 21 st century tool for social and political critique. In this chapter, we draw from social theories of humour which call attention to the relationship of comedy to broader social discourses. Incongruity theory, one of three main strands of humour theory, is useful for this purpose. As Critchley noted in his work On Humour, 'in order for the incongruity of the joke to be seen as such, there has to be a congruence between joke structure and societal structure - no social congruity, no comic incongruity' (2011, p. 3). He further reflected that 'humour returns us to common sense; by distancing us from it, humour familiarizes us with a common world through its miniature strategies of defamiliarization' (p. 17). By 'common sense,' Critchley is referring to the social codes, rules and understandings that communities share. For the gender-related humour explored in this chapter, the comic relief is produced by seeing the obvious similarities between the contemporary welfare state with its discourse on gender equality and the viking settlement staged in Norsemen. Similarly, Samurai Shifters activates our common understanding of figures like the samurai, salaryman and the hikikomori, a concept referring to a severe form of social withdrawal, and it depends on our judgement that a bikikomori young man would be ill-suited for the grand exploits required of samurai nobles during the Edo period.

The idea that humour can be seen as an important factor in the production of meaning in a given culture is also presented by Michael Mulkay in his well-known book entitled On Humour: Its nature and its place in modern society (1988). His theorising of humour is based on two fundamental modes: The 'serious mode' and the 'humorous mode.' In the humorous mode, there are plural realities (i.e., no one discourse has the upper hand) allowing for different discourses to coexist within the same context, unapologetically showcasing the contradictions, flaws and pretension of a 'serious' discourse. Both Norsemen and Samurai Shifters can be regarded as functioning in the 'humorous mode' as gender comedies that expose the tensions and contradictions in current societal discourses on femininity and masculinity.

Finally, within comedy studies, 'stereotypical humour' has been seen as particularly taboo because it often serves as a vehicle to ridicule marginalised groups. In a bold and ground-breaking work on the perils of racial, ethnic and gender humour, Leon Rappoport explains that this type of humour is more complex and much less straightforward and unidirectional than one might believe $(2005$, p. 2). It is above all characterised by ambiguity and is highly context dependent: It can involve any constellation of minority versus minority, majority versus majority, urban versus rural, 
women versus men and vice versa. Its 'appropriateness' may be determined by its proximity to mainstream attitudes (Rappoport, pp. 2-3). Our aim in drawing from Rappoport's reflections is to show that the extreme nature of many of the stereotyped figures in Norsemen and Samurai Shifters make them recognisable and yet so distant from what is culturally acceptable that it becomes laughable.

\section{Masculinity in Norway and Japan}

Recent literature on masculinity in both national contexts has brought to light the diversity of emerging masculinities, locating the 21 st century as a time of intense change for both Norway and Japan. The literature on visual representations of Norwegian masculinity over the past two decades has tended to crystallise around particular types of images: Caregiving fatherhood as a means to become a 'worthy' member of the national community (Dancus, 2011), immature and anxious men in a broader Western context of a 'crisis of masculinity' (Donnar, 2015) and intrepid, viking masculinity in the resurgence of the explorer drama (Sandberg, 2019). In terms of Norwegian masculinity exported to an international audience, one may look to Kristofer Hirvju's role as Tormund Giantsbane, the bearded raider of HBO's Game of Thrones (Benioff \& Weiss, 2011-2019). In interviews featured in the Norwegian media, Hirvju insisted on the difference between his off-screen identity as a supportive partner to a woman with a highcommitment career and a caring father, and his on-screen persona as a dreaded warrior and raider (Marthinussen, 2018).

In Norway, there is a lack of research exploring men's experiences such as those brought to light in interviews with Hirvju: The ideals of work-life balance, 'having it all' and being a good parent and supportive spouse. This lack may owe to the tenor of contemporary debates that focus on men's failings or different dimensions of masculinity viewed separately rather than holistically. The comic effect of Norsemen lies partly in the clash of two kinds of masculinity: A masculinity oppressed by the intimidating task of 'having it all' and meeting all the requirements of a gender-equal society in the 2000s, and the stereotypical hegemonic masculinity of the Viking Age associated with warrior militarism, 'risk-taking, the enforcement of command structures and disciplinary hierarchies, physicality, aggression, violence, and overt expressions of heterosexuality' (Hinojosa, 2010, as cited in Raffield, 2019, p. 818).

In Japan, research on masculinity over the past decades has revealed more nuanced and fine-grained understandings of Japanese masculinity, intentionally displacing the 'salaryman' as the dominant stereotype:

If (representations of) the middle-class, white-collar, heterosexual salaryman powerfully invoke(s) ideologies of national, class and sexuality in Japan, the practices and performance of other people must be seen as acts of challenge and change -potential, playful or purposeful. (Roberson \& Suzuki, 2003, p. 5) 
In the post-war period of economic growth, the salaryman became synonymous with hegemonic masculinity in Japan, symbolising the kigyō senshi or corporate warrior (Dasgupta, 2010, 2013; Hidaka, 2010; Sugimoto, 2010; Vogel, 1963). Masculinity scholar Futoshi Taga (2006) paints a vivid vignette of the stereotypical salaryman, recognisable to most Japanese people:

He is working for a large company or in the public sector and living a middle-class life with a wife and two children in an urban area; his wife is a housewife or a part-time worker, and he is expected to be the breadwinner of the family; he enjoys the benefits of lifetime employment and the seniority-promoting system; in exchange for these benefits, he has a strong sense of loyalty to his workplace and works long hours every day; he is also busy in the evening and on weekends at business entertainment events or associations with colleagues, so he scarcely does much housework or child care; his uniform is a dark suit. (p. 108)

While this figure has been intrinsically linked to Japan's process of industrialisation and nation-building, its antecedents may be traced back as far as to the Edo period. Much like the samurai warrior, the salaryman would be expected to display qualities related to the bushido code requiring loyalty, dedication and self-sacrifice. The economic downturn of the 1990s, however, fuelled doubt about the salaryman's efficacy. More recently, as Taga (2013) points out, factors such as 'globally-expanding feminist agendas,' the equation of masculinity with work, underpinned by stable connotations of gender, class, sexuality and nation, have all been challenged (p. 1). This problematising of the whole equation of masculinity and work (and the equation of femininity with the household) in Japan has emerged in various social, political and cultural arenas and is evidenced in academic and popular writings, in recent television programs focusing on issues like datsu-sara (leaving white collar work to start up one's own enterprise) and even in official publicity campaigns (Dasgupta, 2010). The relationship between masculinity and work has been most seriously interrogated in the figure of the ikumen or 'Japanese child caring men,' the object of a government campaign to get more men to actively participate in child rearing (Ishii-Kuntz, 2019).

In their work on masculinity in Japan, Roberson \& Suzuki (2003) argue the salaryman's dominance - a phenomenon they call the 'ideological hegemony of homogeneity' - has left other forms of masculinity unexamined (p. 4). While in the late 1990s it could be claimed that Japanese popular culture reinforced the salaryman's hegemony in the cultural landscape, today academic and popular texts as well as recent television programs challenge this. For example, TV dramas focusing on issues like datsu-sara have contributed to representations of the diversity of masculinity in Japan. 


\section{Jennifer Branlat and Priscilla Ringrose}

Samurai Shifters fits in this movement, with its playful (un)coupling of the salaryman's associations with the samurai. Director Inudō Isshin positions the counter-figure of the hikikomori as achieving success, thanks to his nonsamurai qualities: Vulnerability, shyness, lack of ambition and lack of combat skills.

\section{Norsemen and Samurai Shifters: Sensitive men wielding weapons}

In Norsemen, viking warriors return from their raid in the south with treasures and slaves, having found a map to a new world of wealth. Season one centres around the tough viking Chief Olav, his hapless brother Orm, Orm's wife (the feisty Frøya) and the conflicted warrior Arvid. Back on land after his voyage, Arvid plans to set himself up with a wife and farm - he has neither - and decides to challenge a local farmer for his wife Liv and land. Arvid then literally slices the unfortunate farmer in half before proceeding to take over his household and marry Liv to quell his anxieties about how he will measure up compared to peers who have already settled down with farms and families. But in spite of his new acquisitions, Arvid struggles to adjust to social life on land and the responsibilities it entails. His warrior skills are put to use defending the village, but in the private sphere he remains stuck as the quintessential henpecked husband. He fails to be a good enough partner to the demanding Liv, not least because she insists on his presence at home, forcing him to leave work on time to attend poetry evenings with other couples.

Norsemen therefore stages Arvid in a comic work-life balance dilemma that raises questions at the core of his identity and critically calls into question the demands of modern relationships. This dilemma forces Arvid to confront his own ideas about being an attractive mate, the importance of material possessions and meeting societal benchmarks for men. Once home, he discovers the difficulties of serving Orm, an incompetent boss while maintaining a healthy work-life balance in partnership with his nagging wife Liv. In particular, he wrestles with the task of being a culturallysensitive partner who can participate in Norheim's poetry club with other couples. Others admonish him for his lack of interest in 'finding other couples to hang out with.' The poetry club scene with Liv, Arvid and the other more cultured couples of Norheim serves to reinforce Arvid's feelings of isolation as he is asked to read his own poem out loud (Helgaker \& Torgersen, 2016):

Liv: So, maybe Arvid, you can read yours? Do you have a poem that is dear to your heart?

Arvid: One two three

Take out your wee wee

Four five 
Grab your bride

Six seven eight

Open up her gate

Nine ten

Fuck her then!

With Arvid's poetry leaving everyone aghast, he is ridiculed among Liv's sophisticated friends, thus prompting self-reflection about whether he can actually achieve anything in his private life.

Satirising platitudes and banalities serve as a frequent comic device in Norsemen as men grasp at seemingly 'wise' words to cope with their difficulties or justify their shortcomings. Arvid declares, in an attempt to boost his sexual self-confidence, 'It's not about the size of the boat, it's about the motion of the ocean.' Other male characters use truisms, statements that sound profound but are so obviously true that they preclude further discussion, that sound as if they come straight from self-help books on relationships or leadership. For example, Olav advises Arvid, 'You mustn't lose yourself in the relationship' to which Arvid responds, 'You know about relationships. It's about give and take.' Orm, in particular, as he takes over as Chieftain in the most incompetent manner possible seems to be making it up as he goes: 'And punctuality is a virtue. Which is something I've decided to start saying.' Other truisms sound like they come from current trends in Anglo-American leadership coaching: 'Be a little solution-oriented,' or 'You have to prioritise.' As spectators, we are encouraged to see these platitudes as comically insufficient coping strategies to deal with a perplexing masculine condition. It is certainly not from truisms that the male vikings will be able to derive some sort of meaningful life guidance.

When Chief Olav decides to leave on a new pillaging mission, the village changes dramatically as his weakling brother Orm takes over. Freed from his aggressive brother's oversight, Orm seizes the opportunity to lead the village in another, more cultured direction. In a satire on largesse and hierarchy, he appoints his slave Rufus as creative director. Next, Orm orders all villagers to surrender their weapons to Rufus in order to create an art installation. Unfortunately, this decision leaves the whole clan vulnerable to attack. As the foolhardy Orm blunders on with his cultural fantasy, his fearless, well-muscled wife Frøya enthusiastically joins the men of another tribe in raiding and pillaging their own defenceless village.

In an interview with the Norwegian newspaper Dagbladet, actor Kåre Conradi (Orm), the 'sensitive viking' leader who fears war and goes to great lengths to introduce the viking village to culture, talked about how he believed it was high time to do something 'fun' with the vikings (2016). The result is a cosmetically plausible viking world. However, digging deeper into the comedy reveals a carnivalesque reversal in the Bakhtinian sense of the modern Norwegian welfare state (Bakhtin, 1963, p. 127). In what might be called an 'anti-welfare state,' we see a viking community that 
uncritically engages in acts of (sexual) violence and pillaging. The satire is clear, however, when conflicted warrior Arvid flippantly declares that 'taking stuff is so fun.' This gratuitous violence stands in stark contrast to the Norwegian self-image of a peace-promoting, generous nation (Skånland, 2014) whose history lies outside of European imperialism (Gullestad, 2005). The comedy also spoofs the Norwegian welfare state's focus on intergenerational fairness and helping the elderly live fulfilled lives. This occurs when Orm's mismanagement of the village's resources leads village elders to engage in the senecidal Ættestup ritual, throwing themselves, or being thrown, to their deaths when they were no longer able to lead independent lives or contribute resources to the village - a potential solution to historical shortcomings in the food supply.

Samurai Shifters takes on the concerns of work relocations and downsizings, controversial issues in Japan since the 1980s. Yet, sudden relocations were also common in the Edo period involving the same stresses, 'unexpected notice, an unfamiliar destination, limited time and funds,' as such moves do today (Haneda, 2019, para. 1). The dilemma of Samurai Shifters starts as the Lord of the Himeji domain is given two months' notice to shift an entire clan of several thousand warriors and their families to a new territory $600 \mathrm{~km}$ away. The new territory is half their current land size; moreover, they must make this move with limited resources and reduced manpower. This herculean and unpopular task is delegated to film's unlikely hero, Harunosuke Katagiri, a librarian and recluse, who prefers the company of books to people. Katagiri is expected to develop a master plan for the entire relocation, as well as to dismiss over half of the clan's samurai. With no prior experience and extreme lack of social skills, Katagiri's only desire is to escape. As luck would have it, however, he must eventually accept his new position despite his reluctance. The story evolves as Katagiri enlists the help of the loudmouth swordsman Genemon Takamura and the strong-minded Miss Oran, the daughter of the former relocation officer, to develop ingenious downsizing and relocation strategies. As he gains experience, Katagiri gradually earns the respect of fellow clansmen, impressing them with his honesty, empathy and egalitarian principles, in what increasingly plays out as a tongue-in-cheek riposte to the rigid hierarchical frameworks of contemporary Japanese working life.

In what follows we examine the ways in which comedy makes a statement about the current state of masculinity. We argue that the humour here depends on spectators' recognition of the difficulties associated with being a man in Norway and Japan today.

\section{Hikikomori masculinity and the pressures of Samurai-Salaryman life}

The opening scenes of Samurai Shifters confirm Katagiri's status as an unlikely hero. A reclusive librarian, his cloistered lifestyle and paralysing 
shyness resonate with the tensions of modern-day hikikomori masculinity. The hero's embodiment of the tragic social misfit is playfully communicated through the teasing banter that his friend Genemon Takamura engages in, poking and prodding him to take on his new role as relocation officer. At the same time, the pressure he is put under by the clan to accept the new job after initially balking at the task and his ultimate inability to refuse his superior's orders leads to his feelings of powerlessness. This sense of having no recourse vividly stages the pressures of the modern-day salaryman.

Hikikomori as a social phenomenon has been observed amongst Japanese young people, mostly young men, since the 1970s. It has gained even more attention since the late 1990s: 'Hikikomoru is a compound verb made up of the two characters for "to pull back" [hiku] and "to seclude oneself" [komoru]' (Kato et al., 2019, p. 427). The term hikikomori refers to individuals who have withdrawn from the group, whether school or the workplace, for months or even years, spending most of the day alone inside their home (Kato et al., 2019, p. 427). The opening narration of Samurai Shifters draws on viewers' familiarity with this phenomenon, foregrounding Katagiri as a 'hikikomori samurai.' We meet this paradoxical figure of the librarian-hikikomori anti-hero in the heart of his place of refuge, his library:

Narrator: The hero of this story is a librarian. The book this young man is now reading is a documentation of the Takeda clan's military strategies. (Inudô, 2019)

The film's journey will thrust the hapless Katagiri, nicknamed 'the snail' and 'shut-in' by his fellow clansmen, out of his closeted cocoon and into the limelight. When Katagiri's friend Genemon Takamura breaks the news to him that he is the favoured candidate for leading the massive relocation project, Katagiri is shocked. Here, the references to 'sunlight' and to Katagiri's response to the call of the outside world evoke the closeted interior lives of hikikomori (Inudô, 2019).

Genemon Takamura: I know a man who is perfect for the job.

Harunosuke Katagiri: Who is that?

Genemon Takamura: It's Snail. Come! It's time to get out into the sunlight.

Harunosuke Katagiri: Leave me alone! No! Ha, it's too bright! My eyes... my eyes! I...I am not good at talking to people!

While sociological discourses often understand hikikomori as 'passive objects' (Overell, 2018, p. 209), they can also be seen as 'wilful subjects,' who refuse to meet social obligations (Ahmed, 2014, as cited in Overell, 2018, p. 206). As such they can be read as queering normative masculinity in Japan, in the sense Sarah Ahmed ascribes to someone who deviates from given modes of being in the world (Ahmed, 2014, as cited in Overell, 2018, 
p. 210). The wilful subject is 'perverse and irritating' (Ahmed, 2014, p. 17). Katagiri embodies the contradiction of the hikikomori, appearing as a passive recluse obsessed with book learning and at the same time wilfully refusing to take on the job offer. He makes his refusal clear in words, but also by trying to run away. He only concedes to take the position when he is given the ultimatum to either accept the role or commit seppuku, a form of Japanese ritual suicide by disembowelment. Rosemary Overell argues that hikikomoris can be understood as 'queer subjects who are out of place and pace with the dominant heteronormative masculinist culture of contemporary Japan' (2018, p. 206). As we will see, as with other Katagiri hikikomori dramas, such as Train Man/Densha Otoko based on the purportedly true account of 23-year-old hikikomori's heroic intervention to stop harassment of a young women on a train, the lonely recluse moves from the margins and finds his way back into society.

At the same time, the Herculean task Katagiri is assigned brings into focus another emblematic symbol of modern Japan - the salaryman. The stereotypical salaryman figure is associated with an all-consuming, intensive workload alongside the demands to perform 'loyalty, diligence, dedication, and self-sacrifice' (Dasgupta, 2017, p. 40). The apparent impossibility of Katagiri's task, combined with his sense of powerlessness, the burden of his friends' and fellow clansmen's expectations, and the multiple logistical and financial pressures the task will involve function as a millstone around his neck. This professional salaryman-type burden is so heavy around the neck of a shy librarian that it becomes comical, especially, as we will see, as Katagiri takes it on in such a way as to destabilise the hierarchical underpinnings of masculine leadership on which they are founded.

\title{
Tidying up with Katagiri: The Marie Kondo School of Samurai Masculinity
}

\author{
\& Sorting, throwing, giving away \\ Packing, handing, finish in time \\ (Inudô, 2019)
}

As Katagiri starts to embrace his new role, his unconventional leadership style plays with gendered ideas about domesticity. As he begins to work out ways for the clan to downsize in anticipation of moving to a smaller territory, he comes up with a 'novel' decluttering strategy, amusingly reminiscent of modern day Japanese domestic trends. Inudo himself confirms that this strategy is a 'cheeky' reference to the philosophy of Japanese decluttering expert Marie Kondo, whose 2016 cult bestseller Spark Joy and Netflix Show Tidying up with Marie Kondo (2019) are all about 'throwing away anything that does not spark joy' (Pringle, 2019). In Samurai Shifters, the clansmen homes end up being Marie Kondo-ed, in a move that turns 
these samurai warriors into reluctant domestic goddesses. The Marie Kondo scene takes place when Katagiri comes up with the bright idea of asking all the local clansmen to get rid of any possessions that they do not need. He suggests they eliminate all objects that 'no longer spark joy,' a direct reference to Kondo's philosophy. In the spirit of egalitarianism, he decides to lead by example, turning on his own possessions and burning dozens of books from his personal library.

However, Katagiri's order to de-clutter does not 'spark joy' in all the clansmen. One member of the clan insists that he cannot comply with the order because his collections are extremely valuable. Demonstrating his newfound quick-wittedness, Katagiri puts the clansman's dependency on his possessions to the test. He covers up everything in the man's room and then asks him to make a list of all his possessions, now out of sight. Katagiri then orders all the valuables which do not appear on the list to be thrown away. The implication is that if that you cannot remember your possessions, then you do not need them. Mimicking the familiar resistance of TV hoarders, the clansman begs Katagiri to relent, while the former holds his ground with Marie Kondo-like self-assurance, substituting the rhetoric of joyfulness to that of attachment (Inudô, 2019):

Clansman: Wait! That one came from China and is priceless!

Katagiri: But you didn't remember it. It means that you felt no attachment to it. So, you don't need it.

As Katagiri is again reinvented, this time as a Samurai Marie Kondo, the film playfully de-couples domestic preoccupation from the world of women, poking fun at established gendered divisions of labour within the Japanese home. The scene produces an imagined comical juxtaposition between the rough and ready clansmen and the 'petite' Marie Kondo. At the same time, the idiocy of tossing valuable antiques represents a playful critique of the more extreme dimension of Kondo's one-size-fits-all philosophy. While the implied ludicrousness of the idea of men tidying up may appear misogynistic, the scene also sanctions such behaviour in the sense that it is initiated by the film's new hero.

\section{The caring sharing leader: Vikings and Samurais in a double-bind}

Season one of Norsemen exposes workplace expectations that place men in a double-bind. Even vikings are simultaneously and humorously expected to be both ambitious leaders with a clear vision and sensitive to relational issues among their subordinates. Returning momentarily to the opening sequence that stages Rufus's arrival in Norheim, we see Chieftain Olav returning to the settlement after several years of raiding and pillaging. He brings back to the village a Roman slave (Rufus), who is exceptionally cultured and ill-prepared for the lack of sophistication he encounters among 


\section{Jennifer Branlat and Priscilla Ringrose}

the vikings. As the ship approaches Norheim, Rufus hesitantly voices criticism with respect to the lack of comfort during the journey and the work and salary conditions he will find in Norheim. In a manner that reveals a misrecognition of his own position and resonates with modern management culture, he criticises the information flow aboard the overcrowded ship (Helgaker \& Torgersen, 2016):

Rufus:

\section{Chieftain Olav:}

Rufus:

Chieftain Olav:

Rufus:

Chieftain Olav (turns to Arvid): Arvid:

\section{Chieftain Olav:}

Not to complain, but I think the flow of information here on this boat is extremely arbitrary. And that's totally uncalled for, when we're so crammed together in such a small craft. I didn't know until yesterday that we were even going to Norway.

So, you think the information flow is under par?

Yes.

So, here's some information for you.

Finally! [Chieftain Olav punches Rufus in the nose] Ow, ow! Did you see that? Did everyone see that? There's something seriously wrong with my nose!

Was that a bit too much?

No, you're the chieftain. Aren't you supposed to be a little like that when you're in charge? A little crazy.

But it's not really me, that fear-based leadership style stuff. It doesn't feel right.

The scene's comic relief unravels at different levels. Olav's unexpected punch fits in with viewers' expectations about the vikings and their lack of diplomacy as well as viking-era power relations between master and slave. The Chieftain's unexpected self-doubt and soul-searching, however, belong more to the realm of the 'soft' and non-confrontational leadership style suited to the flat organisational structure of most contemporary Norwegian organisations. During this sequence, the spectator is drawn to see Olav as struggling to develop a leadership style with just the right balance of fear and feelings.

As Katagiri plans and executes the relocation, the film continues to cast a playful light on the overbearing and unequal practices of the present-day corporate culture. Yet, it also showcases Katagiri as an alternative type of leader. In the end, our hero, the reclusive hikikomori, faced with the multiple pressures of a salaryman's endless debt to the firm and obedience to his 
superiors, is reformed. He is intent on building team spirit, is not afraid of his dependence on others and is determined to call out the classist practices of his predecessors. As such, Katagiri symbolises the best of both worlds - a leader who can take on an enormous task and but who, at the same time, remains a sensitive soul.

Katagiri's egalitarian mindset incites explicit comment by other clansmen. When Oran discusses the mistreatment her father (the lowerclass former relocations officer and Katagiri's predecessor) suffered at the hand of his own boss, this becomes the occasion for Genemon Takamura to praise Katagiri's egalitarian mindset in comparison (Inudô, 2019):

Genemon Takamura: You must be the daughter of Itagaki [former magistrate in charge of relocation].

Oran: Yes

Genemon Takamura: Sajima [bureaucrat] always took credit for the accomplishment of Itagaki and advanced in his career without actually working. I detest that kind of attitude. On the other hand, Katagiri has never pushed people aside. He treats people equally, regardless of their position and class. I admire that.

This favourable comparison is further emphasised by Katagiri's actions when it is his turn to find out that all Itagaki's achievements were credited to his superiors because of his lower-class status. Katagiri then makes a point of going to Itagaki's grave to apologise, an act which earns him the respect of Oran, who was previously unwilling to pass on her father's strategic knowledge to him because of the unfair way her father had been treated. Oran's capitulation then becomes the mechanism for showcasing Katagiri's dependence on a woman - that is to say on the knowledge Oran gained from her father, another step in the road of egalitarian leadership. This same egalitarian spirit is demonstrated when the head of accounts urges Katagiri to take loans from merchants with no intention to pay them back. Katagiri makes it clear that he objects to stealing hard-earned money from ordinary people just because he is entitled to do so as a 'superior' samurai. Embodying a new masculinity, Katagiri continually challenges classist structures and privilege. He even suggests that the samurai abandon their normal privileges and carry their own bags when travelling.

Finally, one of the final scenes of the movie, a rollicking battle scene, demonstrates that successful outcomes in leadership ultimately do not depend on a male top dog. Rather the scene affirms collaborative practices, in which each and every member of the team counts equally. The battle scene opens when Katagiri's travelling group encounters enemy agents disguised as fishermen. As the enemy threatens to overwhelm them, the wisdom of Katagiri's team philosophy is borne out - men, women and children work together to outwit the imposters. Takamura grabs a massive outsize sword, 


\section{Jennifer Branlat and Priscilla Ringrose}

swirling it round with acrobatic dexterity, while a child strategically aims a slew of porcelain plates at the oncoming attackers, both sowing terror in their wake. But Katagiri's strategies come into play too. Since he had already encouraged the samurai to hone their physical skills so that they would be able to carry their own luggage, they are now well prepared to fight the good fight.

In the end our hero, the reluctant hikikomori, changes into a 'New Man' samurai. He exemplifies the best of the bushidō code, emerging as a trusty and wise leader who knows better than to rule by fear. Moreover, in the process, he conquers his own fears, embodying a masculinity hybrid that brings together the best of both worlds, the virtues of traditional bushido masculinity and a novel, more vulnerable manhood.

\section{Conclusion}

This chapter explores the ways in which Samurai Shifters and Norsemen playfully engage with contemporary issues of masculinity, a theme that has dominated debates on gender equality in both Norway and Japan in recent years. We asked: What dimensions of modern masculinities do these comedies explore? To what degree do these comedies uphold or challenge the prevailing social orders in Japan and Norway? Are there any similarities and differences that can be found in the representations of masculinity? Both Norsemen and Samurai Shifters use comedy to establish a frame for an alternative to 'serious' societal discussions about gender roles and gender equality, which tend to focus on men's shortcomings and reflect ambivalence about masculine roles in both the public and private spheres. Toying with recognisable stereotypical male figures, they bring current social tensions relating to men's domestic and working life to light. Samurai Shifters exposes the unbearable burdens of the salaryman, kicks the hikikomori back into society and imagines an idealised leader who represents the antithesis of corporate Japan and the best of bushidō values - all while poking fun at modern domestic obsessions. Norsemen goes further in exposing the persistent tensions and ambivalences of contemporary western masculinity, suggesting that masculine ideals are unachievable when considered as a whole: Reconciling work-related absences with family-building aspirations, the pressure to 'have it all' in terms of a meaningful personal life and career and the conflicted feelings of so-called New Managers who are supposed to embrace the tenants of sensitive leadership. Both comedies focus on the near-impossible imperatives of modern 'caring' masculinity and both depend heavily on viewers' recognition of modern experiences represented in the remote historical worlds. In order to partake in the humour, viewers must recognise their own social world - in particular, the contours, boundaries and 'excesses' of discourse surrounding New Manhood today. The primary difference between these comedies lies in Norsemen pushing viewers to laugh at a gender equality 'gone too far,' while the Japanese 
comedy light-heartedly affirms the potential in the egalitarian values that meet resistance in Japan's contemporary rigid social hierarchy. Both of these works affirm the essential role of humour in allowing us to step away and see the gender equality of our own social worlds from the outside, reflected in the metallic sheen of the samurai and vikings swords.

\section{References}

Ahmed, S. (2014). Willful subjects. Duke University Press.

Bakhtin, M.M. (1963). Problems of Dostoevsky's poetics. University of Minnesota Press.

Benioff, D. \& Weiss, D.B. (Creators). (2011-2019). Game of Thrones [Series]. HBO Entertainment.

Critchley, S. (2011). On bumour. Routledge.

Dancus, A. (2011). A father's body, a nation's heart-caregiving fathers in contemporary Norwegian film. NORA - Nordic Journal of Feminist and Gender Research, 19(2), 71-86.

Dasgupta, R. (2010). Globalisation and the bodily performance of 'cool' and 'uncool' masculinities in corporate Japan. Intersections: Gender and Sexuality in Asia and the Pacific, 23. http://intersections.anu.edu.au/issue23/dasgupta.htm

Dasgupta, R. (2013). Re-reading the salaryman in Japan. Routledge.

Dasgupta, R. (2017). Articulations of salaryman masculinity in Shôwa and PostShôwa Japan. Asia Pacific Perspectives, 15(1), 36-54.

Donnar, G. (2015). Male anxiety, inadequacy and victimhood: Insecure and immature men in recent Norwegian cinema. Journal of Scandinavian Cinema, 5(2), 155-168.

Gullestad, M. (2005). Normalising racial boundaries: The Norwegian dispute about the term neger. Social Anthropology, 13(1), 27-46.

Haneda, R. (2019). 'Samurai Shifters' is a comedy full of work efficiency, teamwork tips we can all instantly incorporate into our careers. Japanese Film Festival Magazine. https://jff.jpf.go.jp/read/column/3954/

Helgaker, J. \& Torgersen, J. (Creators). (2016-2020). Norsemen [TV series]. Norsk Rikskringkasting AS.

Hidaka, T. (2010). Salaryman masculinity: The continuity of and change in the begemonic masculinity in Japan. Brill.

Hinojosa, R. (2010). Doing hegemony: Military, men, and constructing a hegemonic masculinity. Journal of Men's Studies, 18, 179-194.

Inudô, I. (Director). (2019). Hikkoshi Daimyo!/Samurai Shifters [Film]. Shochiku.

Ishii-Kuntz, M. (2019). Japanese child caring men (ikumen) and achieving work-life balance. In U. Meier-Gräwe, M. Motozawa, \& A. Schad-Seifert (Eds.), Family life in Japan and Germany. Springer.

Kato, T.A., Kanba S., \& Teo, A.R. (2019). Hikikomori: Multidimensional understanding, assessment, and future international perspectives. Psychiatry and Clinical Neurosciences, 73(8), 427-440. https://doi.org/10.1111/pcn.12895

Kondo, M. (Executive Producer). (2016). Tidying up with Marie Kondo. The Jackal Group.

Marthinussen, L.C. (2018, 16 February). Kristofer Hivju: Det å være en samlet familie, veier tungt for meg - 'Game of Thrones'-stjernen åpner opp om 


\section{Jennifer Branlat and Priscilla Ringrose}

familielivet [Kristofer Hivju: Being a united family weighs heavily on me - 'Game of Thrones' star opens up about family life]. Se og Hør. https://www.seher.no/ kjendis/det-a-vaere-en-samlet-familie-veier-tungt-for-meg/69522911

Mulkay, M. (1988). On humour: Its nature and its place in modern society. Polity Press.

Overell, R. (2018). Queer will: Hikikomori as willful subjects. Inter-Asia Cultural Studies, 19(2), 206-219. https://doi.org/10.1080/14649373.2018.1463069

Pringle, G. (2019, 1 November). Isshin inudo: Life of samurai. Filmink. https:// www.filmink.com.au/isshin-inudo-life-samurai/

Raffield, B. (2019). Playing vikings: Militarism, hegemonic masculinities, and childhood enculturation in Viking Age Scandinavia. Current Anthropology, 60(6), 813-835.

Rappoport, L. (2005). Punchlines: The case for racial, ethnic, and gender humour. Praeger.

Roberson, J., \& Suzuki, N. (2003). Men and masculinities in contemporary Japan: Dislocating the salaryman doxa. Routledge.

Sandberg, E. (Director). (2019). Amundsen [Film]. SF Studios.

Skånland, Ø.H. (2014). Norway is a peace nation: A discourse analytic reading of the Norwegian Peace Engagement. Peacebuilding, 4, 23-45.

Sugimoto, Y. (2010). An introduction to Japanese society. Cambridge University Press.

Taga, F. (2006). Westernization or Hybridization?: Restructuring Japanese Hegemonic Masculinity in Globalization [Conference paper]. XVIII ISA World Congress of Sociology. Yokohama.

Taga, F. (2013). Review of the book 'Salaryman masculinity: The continuity and change in the hegemonic masculinity in Japan' by T. Hidaka. Contemporary Sociology, 42(3), 391-393.

Turner, G. (2006). Film as social practice (4th ed.). Routledge.

Vogel, E.F. (1963). Japan's new middle class: The salary man and his family in a Tokyo suburb. University of California Press. 


\section{Work-life balance and equality observed through advertising during the COVID-19 pandemic in Japan and Norway}

\section{Chibiro Wada and Roger A. Søraa}

\section{Work and home under the COVID-19 pandemic}

The COVID-19 pandemic has altered the ways in which people live and work at home. New trajectories have emerged regarding the balance between work time and leisure. As pandemic lockdowns have confined people to their homes, the distinction between one's work life and home life has blurred. In turn, these changes have affected individuals' sense of their responsibility as workers and co-dwellers. How have people perceived this change? What new narratives have arisen to make sense of it? In this paper, we investigate how advertisements geared to national audiences represent Japanese and Norwegian households' ways of striking a balance between a new kind of work and home life. Specifically, we ask how advertisements envision balancing working at home during the pandemic while doing necessary housework and caregiving. We focus in particular on the perceptions of certain domestic tasks as gendered and narratives about the balance between work and home in everyday life.

Work is gendered and situated in material practices. Where we work, how we work, what we work with and whom we work with intimately shapes human beings as individuals and as members of different social groups, such as households. As the COVID-19 pandemic emerged during the early months of 2020, societies across the globe began to change drastically in multiple ways, particularly regarding how work is enacted as a material practice.

This global observation also holds true for Japan and Norway, the countries where we made our observations. Japan, with its customarily long workhours, strongly gendered barriers in the workplace and gendered division of domestic work may offer interesting ways in which a workforce faces the challenge of working from home. On the other side of the globe, the Norwegian workforce, with its short, efficient work hours, shows ways of working in the pandemic that are similar to but also quite different from those of the Japanese. The pandemic has changed societies in terms of where people work and how society envisions that workers will situate the socio-materiality of home and work. The challenges of this unexpected 
situation offer a ripe opportunity for advertisers to spin new narratives of work-home balance that integrates and sells their products. But how do advertisers handle this new situation, and what are their focus areas when it comes to remote work?

We compare these two work contexts through the conceptualisation of work from home through representations of work and family in advertisements. Social values are often reflected through commercials, which portray, satirise and otherwise comment on social structures and events (Cheng \& Schweitzer, 1996; Klassen et al., 1993; Kunkel \& Roberts, 1991), including the events of the COVID-19 pandemic. Ads also have the power to change social norms and impact how we relate to topics. We will argue that advertisements in both Japan and Norway have tended to focus on the newness of men's attention to housework and parenting amid the transition to remote work, while underscoring their essential role as the family's primary breadwinner. Similarly, women's roles as primary caregiver and homemaker remain unquestioned, while commercials express sympathy for their need to balance domestic duties with their paid employment. Family-centred commercials in both countries continue to identify the family as abled, cisgendered and heterosexual, although ads in Norway tend to allow for more diversity in this regard. In Japan, this idealised family belies the actual variety in household configurations.

We argue that advertisements geared to national audiences represent Japanese and Norwegian households' ways of dealing with the balance between a new kind of work and home life. Gendered narratives about the balance between work and home in everyday life can be seen through looking at how ads conceptualise the situation. These representations can thus provide valuable insight both on how 'work' and 'home' is gendered.

\section{Method and analytical approach}

We selected nationally broadcasted advertisements from Japan and Norway by searching for online advertisement videos released prior to December 2020. We ascertained their release dates based on those indicated on official webpages associated with the advertisements and the official YouTube channels of the companies that produced the videos. Videos were chosen as a media rich in content, narrative, and social commentary.

We performed content analysis on the framing of working from home in these video texts. A total of 54 advertisements from Japan were selected for analysis; these included ten advertisements that predated the pandemic period (released in the late 2010s), seven broadcast around the beginning of the pandemic period (January to March 2020) and 37 broadcast during the pandemic period (April to December 2020). Norway has a smaller commercial market than Japan, which implies fewer relevant commercials. Thus, for Norway, we selected a total of 49 advertisements: Ten that predated COVID-19, seven broadcast from around the onset of the pandemic 
outbreak and 32 broadcast during the pandemic period. A Google video search using the keyword 'COVID-19 commercial' conducted in June 2021 found over 101 million videos on the topic globally. By using the keyword 'Corona commercials' (Korona CM in Japanese), about 4.88 million videos were found in June 2021; the same search in Norwegian (korona reklame) yielded 119,000 results. These numbers show that this study cannot be considered a representative quantitative analysis over all possible commercials on the topic. However, this selection does shed light on the topic at hand in Japan and Norway, as they tell stories about how societies were adopting to new rules and norms during the pandemic. The text of the Japanese and Norwegian advertisements was translated into English by the authors.

In our analysis, we first explored gender and representations of home and work-life balance in advertisements in Japan and Norway that were broadcast before the pandemic, analysing their conceptions of workers. We then turned to pandemic-period advertisements with the same questions, which constitute the main part of our study. Investigating the topological connections between gender and work before and during the pandemic, we focused our analytical lens on the ways in which commercial depictions engrain and habituate roles, practices and symbolic meanings.

\section{Pre-pandemic: Work-related advertisements showing Japanese salarymen and Norwegian working mothers}

To understand the pandemic period, we first ground our analyses in advertisement depictions of work before the pandemic. Work and gender roles have long served as themes in advertisement and, at times, incited viewer outrage. The depiction of women in a 1975 advertisement for ramen by the Japanese corporation House Foods, for example, famously sparked controversy based on its celebration of a gendered division of labour in the home (The Asahi Shimbun Corporation, 1975, p. 23). A young woman and her small daughter are shown standing and singing that they are going to make ramen for the husband and father, who is sitting at the table. They are accompanied with the slogan, 'I'm the girl who makes it - I'm the guy who eats it,' (Watashi tsukuru bito, boku taberu hito).

Though Japanese advertisements often depict conventional gender norms, some changes in gender representation have been made. The representation of men cooking meals has increased since 1986 when the equal employment opportunity law was enforced (Yoshida, 1998, pp. 140-1). After 1991, when the bubble economy burst and employment amongst men fell, advertisements started to depict the emerging reality of men being at home with the children (Yoshida, 1998, p. 154). However, advertisements conventionally reflect gender norms and often describe women engaging in unpaid work at home while men work outside home (Nobeshima, 1998; Yoshida, 1998). The image of the suited salaryman, always busy at work, 


\section{2}

has been the conventional representation of the masculine ideal in postwar Japan (Abe et al., 2006; Connell, 2005, p. 200; Dasgupta, 2013). Contemporary advertisements continue to reflect these societal gender norms, even in the face of changing familial configurations, as seen in studies of Japanese television ads in the early 2000s (E, 2003; Pongsapitaksanti, 2008).

While political campaigns try to change the social situation, women still take the main responsibility of child-rearing in Japan. In 1999 the Japanese Ministry of Health, Labour and Welfare (MHLW) launched a campaign to ameliorate the declining birth rate. Further, in 2010, the MHLW launched its Ikumen Project, which called on men to participate in child-rearing. The neologism ikumen is composed of $i k u$, meaning 'to raise children' and the English word men - a wordplay on the slang expression ikemen (handsome men). However, despite this campaign, only $7.48 \%$ of eligible men took parental leave in 2019 (while $83.0 \%$ of eligible women took maternal leave) (Ministry of Health, Labour and Welfare 2020). While the number of men opting for parental leave is increasing especially after 2012, women still make up the overwhelming majority of those taking leave from work to raise children (see also Chapter 3 in this book).

Representation of male engagement in housework and childcare is often uncritically accepted by the viewers. In 2017, a diaper advertisement by Unicharm Corporation (Moony Promotion, 2017), which depicts a woman busy with housework and child-rearing while her husband does nothing, sparked controversy amongst the public. We see the reverse scenario in a 2014 advertisement for softener by Lion Corporation showing a busy house husband sawing or shopping all alone, which received no public backlash (Miyashita, 2020, p. 101). Miyashita (2020) argued that the commercial's intended viewership (probably women) likely regarded this scenario as unrealistic and the representation of a house husband purely fantasy (p. 101).

Advertisements broadcast before the coronavirus pandemic in Japan often depicted men in suits working long hours, but several also illustrated men working and raising children. ${ }^{1}$ While these attempts at disrupting hegemonic masculinity have sometimes led to mockery, ${ }^{2}$ such images endured in the pre-coronavirus Japan of the late 2010s. For instance, one advertisement for a drink that prevents hangovers in 2019 depicts suited men doing 'nomikai' - a Japanese custom to drink alcohol with their business associates after their work as a part of their business activity - with the product as they smile. ${ }^{3}$ However, nomikai is sometimes ridiculed as a bad example of a custom of long-working hours.

Going against the grain, some advertisements broadcast in Japan from the late 2010s show women at work and some even depict men raising children. A commercial for a toilet detergent, for example, depicts a woman wearing a suit at work and being tired of overwork. She suddenly cleans a toilet next to her desk and says 'It feels great!' (ST-Corporation, 2019). 
Although only one out of ten advertisements in our sample describes work from home, the protagonist of the advertisement was a man who was engaging in childcare. This coffee ad from Suntory Beverage \& Food Limited (2017) shows a young man raising children while working remotely, concluding with the motto, 'A new wind is blowing.' Reinforcing the 'newness' of this scene, the advertisement also shows people bringing their pet dogs to the office, suggesting the potential for new styles of work in Japan. Thus, advertising in the late 2010s, before the spread of the novel coronavirus, included depictions of conventionally suited salarymen and career women working busily away from home. Much less common were depictions of men taking part in housework and child-rearing.

Turning to Norway, we find an entirely different situation. Since the 1980s, Norway has required advertisement narratives to support gender equality politics (Berg et al., 1979):

1 In commercials with one person - flip the gender of the person shown to the opposite gender.

2 In commercials with both genders, let men and women change roles.

Berg et al. (1979) argued that as long as the resulting gender change did not require any alteration to the rest of the storyline of the advertisement, it would fairly represent and help normalise gender equity. Berg et al. also recommended that commercials use the same number of men and women. The strongest directive was that to flip gender roles, for example, to show compassionate men in caregiving roles and gregarious women meaningfully engaged in the public domain. A commercial for Telenor (1997) provides a good example of this. Seeking to discover what it calls 'solutions for the country' (loosely meaning, 'things that can be improved'), the commercial shows a working mother dealing with difficult male bosses. Clearly, they do not think that she can become an effective leader since she must care for her sick child. With the help of a female secretary, however, the woman manages to impress them while excelling at work and providing childcare. The message is thus that women can actually do it all just as well as men, but also that comradeship and sisterhood among working women should be applauded.

As we see, in both Norway and Japan, commercials have made groundbreaking representations of both domestic and working life and have also reinforced stereotypes. In both countries, the portrayal of the workingmother or career-woman balancing work and home life has surfaced as particularly important. Our study found, with few exceptions, the woman represented as a parent as well. Notably, Norwegian commercials depict women's careers as enhanced, not limited, by their having children, as we saw in the 'solutions for the country' video. They regularly portray childcare responsibilities in a way that shows women being able to handle multiple roles, issues and tasks. These positive maternal figures contrast 


\section{4}

with commercials featuring men, which often depict them as the implicitly single and childless career-man - or downplaying and not focusing on their role in the home life. Also, after the 2000s, particular scrutiny has been put on the retouching of commercial posters, and out of context body-focus, as Engesbakk (2007) discussed. Examples include companies selling contact lenses, but showing nude women sitting around (with little focus on their eyes), and the sexualisation of women drinking coffee and the general retouching of commercial posters, such as in H\&M underwear commercials.

The long-held social norm which positions the husband/father as the primary breadwinner and the wife/mother as primarily devoted to housework and child-rearing remains a powerful trope of middle-class life, especially in Japan. This conventional portrait often overshadows actual diversity in society, such as the increasing existence of single and LGBTQ+ households. In Japan, there has been little media representation of this variety, while in Norway, diversity of cast has been increasingly represented in recent years. In fact, in 2021, it is quite common to see portrayals of queer couples in commercials. This coincides with the Norwegian Labour and Welfare Administration's decision to move away from focusing policies primarily on housewife politics in the 1970s, to also including those regarding single parents and LGBTQ+ couples after the 2000s. This can be seen on their official site (Arbeids- og velferdsetaten [NAV], 2020), with thorough rules, for example, for gay and lesbian couples raising children together, with different rules for surrogacy and adoption cases. This trend has shaped commercials in Norway too, which increasingly spin scenarios involving various family compositions and close relations outside the traditional nuclear family model. In Norway, working from home was not often thematised in commercials before the pandemic. How did advertisers thematise working from home when this became a new norm during the COVID-19 pandemic?

\section{The pandemic era: Work-related advertisements in Japan and Norway}

Work-related advertisements that have appeared during the pandemic era in Japan and Norway show similar depictions of working from home and child-rearing as people adapt to the pandemic. However, these advertisements also reveal several differences between adaptations to this situation in the two countries.

Japanese advertisements have started depicting remote meetings as the representation of a new type of workstyle rather than a temporary workaround. These advertisements show working women and men mutually engaging in child-rearing and housework at home. But male participation in child-rearing tends to be the main theme, clearly marked as the 'newest' part of the new workstyle. In contrast, women's work receives less 
attention, signalling that women's productive labour in the workforce and reproductive labour in the home are hardly considered anything new.

On 7 April 2020, a state of emergency was declared in seven prefectures, including Tokyo, in response to the novel coronavirus pandemic. This period can thus be tentatively identified as the point when public concern was strongly drawn to the novel coronavirus in Japan, as foreshadowed by the Yokohama cruise-ship incident, an early instance of coronavirus in Japan in February 2020. Advertisers, too, responded to this concern, as around the time that people in Japan began to implement social distancing and take remote work seriously, many advertisements began to show multiple people communicating remotely via computers. Of the 16 ads which describe work from home in our sample from this period, 12 depict remote meetings using computers. An advertisement for a man's suit company, for example, depicts four men sharing work information on a computer screen (The Suit Company, 2020).

This increase of remote meetings portrayal reflects the new reality of remote working. The percentage of employees who experienced remote working has increased from 10.3\% (December 2019) to $27.7 \%$ (May 2020), which declined to $21.5 \%$ in December 2020 (Cabinet Office, 2021). Although there is a gap between different occupations, the overall number of people who experienced remote working increased, and commercials during this period reflected this situation.

Whereas commercials depict women 'balancing' paid work, childcare and housework, men are shown as adding childcare to their work from home. Interestingly, these ads are all produced by multinational companies, which may signal their adherence to representations of work acceptable in other developed countries. Moreover, while 10 out of the 16 pandemic-era advertisements in Japan in our sample present individuals working from home while engaged in housework or childcare, only one focuses solely on women. Many ads depict both men and women active together in their homes, but male engagement in child-rearing tends to be the main theme. It is the 'newness' that attracts viewer attention. For example, an advertising campaign on clothes appropriate for remote work launched by apparel manufacturer UNIQLO Co., Ltd., uses the catchphrase 'New normal. New workwear.' The version of the remote-wear product made for men features the slogan 'For work, for parenting,' while the slogan for the women's product states, 'Pants that make me feel positive.' The text on the website selling the same women's pants reads, 'Work, hobbies, parenting is never a zero-sum game. In this new lifestyle, they all matter.' The UNIQLO ads assume that today's women all continue to raise children as they work inside and outside the home, while men have added parenting as a new activity. ${ }^{4}$ An add from Kureha Corporation's advertisement for plastic food wrap also presents a working man engaging in housework and childrearing. The website for this campaign champions dual parent engagement housework and childcare as the trend, asserting, 'In more and more 
families, it is not a matter of who should do it, but of doing it together. ${ }^{5}$ These advertisements by UNIQLO and Kureha portray two-income families in which men participate in housework and child-rearing, although these were previously duties handled entirely by women.

The 'positive' representation of men engaging in childcare does not reflect a reality. Through experiencing remote working, women felt that their burden on housework and child-rearing increased while men enjoyed the decrease in commuting time and women were less satisfied than men with the sharing the burden of childcare and housework with their partners and $35.2 \%$ of them wanted their partners to do more housework (while only $18.5 \%$ of men wanted to) (Gender Equality Bureau Cabinet Office, 2020).

These observations will be re-examined comparatively after studying commercials designed and disseminated in Norway during the same period.

\section{Return of domestic work and noisy children in Norway}

Prior to the COVID-19 pandemic, it was found that in Norway $33 \%$ of employees reported being able to work from home from at least a half-day per month (Øksnes, 2018). However, working full-time in a permanent home office situation is quite different. After the first coronavirus infection was discovered in Norway, on 26 February 2020, the country took drastic measures and closed down on 12 March, with workers who were able to being asked to set up home offices, such that many people were working from home from March to December. As in Japan, this new normal, where individuals did not know how long their home office situation would last, led to many commercials and advertisements thematising and capitalising on the situation, both by portraying people working from home and by selling them equipment for their new work environment.

As a result, working from home themes became widespread in commercials during the pandemic. For example, the Norwegian commercial from mobile phone operator Telia released a commercial called 'The show must go online' (2020). Against the background music of the rock group Queen's well-known song, 'The show must go on,' the commercial features the tagline, 'Suddenly the internet became more important than pants.' The humorous commercial shows four people carrying on a job-meeting online from home (and without wearing trousers). A man in his 60s is comically shown wearing animal slippers and using a robot vacuum cleaner to dust his floor while he is in the meeting. A woman in her 40s, meanwhile, is shown using nail-polish on her toenails.

Gender roles also served as an important topic in relation to working from home. In a Norwegian commercial advertising the largest bank in the country, Den Norske Bank (2020), we are shown a multitude of people dealing with having to work from home. This commercial presents depictions of gender and work roles commonly found in other Norwegian commercials. Although both men and women are shown taking care of 
children through home schooling or other means in the commercials, quite different practices appear, too. For instance, women are often shown as engaged in self-care (cutting hair, polishing nails), but looking sad nonetheless about their confinement in the home. In contrast, men are shown enjoying their pandemic life by working out or having fun with pets; in one montage, we are even shown a man working out doing push-ups while a woman sits on his back. The product of the commercial is a telecommunication service of broadband being sold, so what the people do with the increased internet speed as portrayed in the commercial can be quite broad.

The COVID-19 crisis has had gendered consequences, especially in regard to work. Globally, women constitute $70 \%$ of the healthcare workforce on the frontline of the pandemic (Pozzan \& Cattaneo, 2020). Evidence shows that during the pandemic, Norwegian women have devoted more time to their domestic work and care work due to working from home, including increased care tasks for both older and younger generations (Nergaard, 2020). One rector at a Norwegian university, for example, suggested that female workers should be given priority when returning to university work to compensate for their pandemic caregiving burdens (Strand \& Schei, 2020). These issues about women's labour at home and in healthcare have not seemed to translate into the world of advertisement, which often focuses women's engagement in self-care.

Children, interestingly, often play the role of 'noisy villains' in commercials. For example, a commercial by one of the largest building-stores, Byggmax (2020), depicts a man intentionally locking himself out of his home in order to escape his noisy children. In most commercials featuring children, focus is put on how noise adds a negative layer to the home, enhancing the sense that things are out of place. Although one could argue that children, not work, are the natural habitants of the modern home, commercials imply that the pandemic has upset the norm. Norwegian childcare policies have focused on enabling women to work through improved state-supported public kindergarten services.

A Norwegian labour force survey of the population aged 15-74 showed $73.8 \%$ male work employment and $67.9 \%$ female work employment, with $36.8 \%$ of women working part-time, compared to $12.5 \%$ of males (Statistisk Sentralbyrå [SSB], 2019). This part-time model is often coupled with unpaid informal care-work responsibilities.

The 'noisy children' trope in commercials reflects the disruption caused by a lack of the normal access to childcare in Norway during the pandemic. The Norwegian societal model of the welfare state, which enables a high participation of women in employment, is thus now under stress. Institutions have closed down or are quarantining, thereby increasing domestic and care responsibilities within households. Although the 'working mom' trope as a model of women working after having children faces new challenges due to the pandemic with digital home-schools, the measures that have been taken hastily in the pandemic do not necessarily aim to 
prevent or mitigate this threat, but rather is a measure to get by for now. The advertisements analysed did not problematise to any significant degree the increased burden of care on women, but they did show many fathers taking on care responsibilities.

\section{Comparing Japan and Norway: Emerging paradoxes}

The pandemic has made working from home necessary for a wide variety of workers. Our examination of Norwegian and Japanese advertisements previous to and during the pandemic has uncovered common themes. Most pertinent to our study were narratives about the balance between domestic work and paid work, both of which took place in the home to a greater degree during the pandemic. Prior to the pandemic, Japanese women spent 208 minutes per day on housework, compared to 44 minutes for men in 2016 (Statistics Bureau Japan, 2017). Even though Japanese women now need less time for housework than they did 20 years ago, they still hold more responsibility for it than men, which can be linked to sociocultural factors.

Women in Norway also still do more housework than men, spending 110 minutes a day on average, compared to 60 minutes for men. Yet, there has been movement toward gender equity in Norway: Women have more than halved the time they spend on housework over the last 50 years, partly due to technology and more efficient ways of doing housework, while men have increased their time by $55 \%$ (Bufdir, 2016). It is interesting to note that $52 \%$ of Norwegian men but only $36 \%$ of Norwegian women feel that the responsibility for housework is shared equally. Although Norwegian women do less domestic housework than they did in the 1970s, and men do more, the balance is still unfavourable to women (Vaage, 2012). Ellingsæter \& Kitterød (2021) found that Norwegian fathers do both more housework and care work, which they thematise as 'family work,' but that women still do much more of all categories. Also worth noting is the socio-economic aspect, as men with higher education do more than those with lower education, according to Ellingsæter \& Kitterød (2021).

Gender inequality in housework responsibilities is closely related to the cultural definition of expectations for both domestic life and what constitutes normal. As depictions of remote work increase, advertising has come to show more scenes depicting work-life balance, which in Japan generally relates to the 'new' trend of men's involvement in raising children. As noted above, in our sample, advertising in Japan has featured depictions of working women and men raising children and doing housework since the late 2010s. However, at the same time as those developments, the image of the busy salaryman has also remained common in Japan. Beginning with the spread of the novel coronavirus, depictions of remote work in Japan in ads have increased, and men's participation in child-rearing has come to be portrayed in a positive light. However, conventional family norms are still 
being represented and recapitulated and women are being pushed to the margins by men's representation. In the advertisements in Norway, we noted in particular that although fathers were positively represented when shown taking care of their families, the families themselves were not always portrayed positively. Children were often portrayed as noisy disturbances for the man working from home. Women portrayed working from home were often shown as angry or depressed, as well as overly interested in selfcare through their use of beauty products. Our analysis has led us to three gender work paradoxes for further enquiry, as described in the following subsections.

\section{Reworking the happy family myth}

Many advertisements appear to challenge conventional gender norms but traditional family roles are quietly reworked into the context of the novelty of remote work. As the above analysis indicates, the advertisements collected here tend to depict heterosexual couples raising abled children, with both parents working and sharing housework and parenting responsibilities. While this was true in both contexts, it was particularly evident in the Japanese selection. Diverse families such as those of single people, single-parent households, same-sex couples, or families without children appear very seldom in Japanese commercials compared to the Norwegian ones. Remote work serves as a prompt to integrate women's work inside and outside the home and adds men's housework and child-rearing to existing family norms, amid the continuing depiction of the conventional happy, abled and heterosexual family.

\section{The marginalisation of women}

Our analysis of advertisements in Japan and Norway highlights the depiction of remote work and men's participation in child-rearing, as well as how this depiction reflects women's double burden. The novelty of remote work reflected in the Japanese advertisements analysed is mainly attributed to men's home life and not to women's work life. Styles of work in twoincome households have undoubtedly changed for both men and women, and the focus in advertisements is on the men who are participating in housework and child-rearing - or as we saw in Norway, their use of robot vacuum cleaners to avoid housework. The advertisements discussed do not focus much on how housework and child-rearing has actually changed for women in the pandemic, and often risk reproducing gender stereotypes.

\section{Technologies alone do not bring equality}

We might expect that advancing technologies could diminish housework, thereby reducing concerns about who has responsibility. Novel technologies, 
however, do not by themselves rewrite conventional gender roles (see Wajcman, 1991); rather, we must continue to discuss the meanings attached to women's labour in society. We do not see any attempt, however, to draw attention to this issue in contemporary advertisements. The move of leaping directly to depictions of men's novel participation in housework and child-rearing, while bypassing the women who are the ones actually taking parental leave or shouldering both work and household duties, has an insidious effect, although we do see in the examples of the noisy children in commercials that parenting is not presented as being without friction.

\section{Conclusion}

This chapter has investigated how advertisements in Japan and Norway have portrayed the novel COVID-19 pandemic's effect on work. This has been done by selecting and analysing advertisements in Japan and Norway for their portraits of new configurations of remote work and their effect on gender roles within the family. The primary advertisements chosen were first published during the COVID-19 pandemic, with some earlier ones analysed as well to contextualise the two countries. In Japan, the image of the busy, suited male salaryman of the late 2010s is retained, but the newer advertisements also use images of remote meetings on computer screens to symbolise remote work, concurrently evoking the participation of men in housework and child-rearing as desirable. More often, the changes in men's tasks is the focus, while women do not feature much in the changed portrayals of home-work balance. In Norway, the reworking of the workingmom trope continues to be portrayed in the pandemic-themed advertisements, but here as well, fathers are also featured. Children were not portrayed in a favourable manner in many instances, but a tension was shown between quiet workplaces and noisy homes in multiple commercials. Our analysis of the commercials focused on lifestyles, styles of work and ideas of gender depicted therein. In comparison, while these advertising trends depicted the novel topics of remote work and men's participation in housework and parenting, under the surface they continued to perpetuate conventional family norms as well as the marginalisation of women. This was the case for both Japan and Norway, but with less diversity of gender roles in Japan, apart from a remarkable focus on men's involvement in child-rearing roles. The question of whether the society-transforming event of remote work during the COVID-19 pandemic has changed gender roles in the home should wait for a post-pandemic study, but our enquiry into the world of advertisements suggests that work-life balance and equality are undergoing novel gendered tensions through this sudden rebalancing between work and home. 


\section{Notes}

1 The products promoted here include coffee and a web magazine.

2 One advertisement for an air freshener depicts a busy salaryman who sings to enjoy his work. Viewers are expected to be sympathetic to him and at the same time, laugh at the situation.

3 The original video by Kowa Company Ltd. has been removed.

4 These differences were seen in September 2020. The website has been changed and the same text was seen to be used for both women and men in March 2021. https://www.uniqlo.com/jp/ja/contents/feature/smart-pants/women/

5 The original video has been removed.

\section{References}

Abe, T., Obinata, S., \& Amano, M. (Eds.). (2006). Danseishi3: Otoko rashisa no gendaishi. [Contemporary history of 'manliness']. Nihonkeizaihyouron Sha.

Arbeids- og velferdsetaten. (2020). Foreldrepenger. [Parental benefits]. [Website]. https://familie.nav.no/om-foreldrepenger

Berg, A.M., Kallerud, B., \& Melby, K. (1979). Reklame og kjønn: en utredning om kjønnsundertrykkende reklame. [Advertising and gender: A study of gendersuppressing advertising]. [Report]. https://www.nb.no/nbsok/nb/4878fa7c57b612 8af532544b0f0f965f?index=1

Bufdir. (2016). Tidsbruk og kjønnsforskjeller [Time use and gender differences]. [Report]. https://bufdir.no/Statistikk_og_analyse/kjonnslikestilling/Familie_og_kjonn/Tidsbruk/\# : :text=Av\%20alt \%20husholdsarbeid \%20er\%20det,sin \%20tid\%20brukt $\% 20 \mathrm{p} \% \mathrm{C} 3$ $\%$ A5\%20husarbeid

Byggmax. (2020). John blir handy - Hjemmekontor [John becomes handy - Home office]. [Video]. YouTube. https://www.youtube.com/watch?v=52JGV6TRX-I\& ab_channel=ByggmaxNorge

Cabinet Office. (2021, 4 June). Dai sankai shingata koronauirusu kansenshou no eikyouka niokeru seikatsuishiki - koudou no benka ni kansuru chousa [The 3rd survey on transition of the general public's views and behaviour under the novel coronavirus pandemic]. [Report]. https://www5.cao.go.jp/keizai2/wellbeing/ covid/pdf/result3_covid.pdf

Cheng, H., \& Schweitzer, J.C. (1996). Cultural values reflected in Chinese and US television commercials. Journal of Advertising Research, 36(3), 27-46.

Connell, R.W. (2005). Masculinities (2nd ed.). University of California Press.

Dasgupta, R. (2013). Re-reading the salaryman in Japan crafting masculinities. Routledge.

Den Norske Bank. (2020, 20 March). Hjemme fra A til $\AA$ [Home from A to $\AA$ ] [Video]. YouTube. https://www.youtube.com/watch?v=eQXZmByYdnk\&ab_ channel=DNB

E, J. (2003). Terebi koukoku ni okeru jenda byousha no nikkan hikaku kenkyu [A comparative content analysis on the gender portrayals in Japanese and Korean TV commercials]. Tetsugaku, 110, 37-57.

Ellingsæter, A.L., \& Kitterød, R.H. (2021). Den 'uferdige' revolusjonen: Hva betyr utdanning for fedres familiearbeid? [The 'incomplete' revolution: What does education mean for fathers' domestic work?]. Tidsskrift for samfunnsforskning, 62(1), 27-50. 
Engesbakk, S. (2007). Reklame, kvinne og reklamekvinnen: En undersøkelse av markedsføringen mot kvinnen og de etiske konsekvenser dette får. (Advertising, women and the advertising woman: A study of marketing towards women and the ethical consequences this has). [Bachelor's thesis]. Umeå University. http:// www.diva-portal.org/smash/record.jsf?pid=diva2\%3A140434\&dswid=4501

Gender Equality Bureau Cabinet Office. (2020). Reiwa ni nendo 'Danjyo kyoudou sankaku no shiten karano shingata koronauirusu kansenshou taisaku ni kansuru chousa' chuukan houkoku sho [Year 2020 'Survey on novel coronavirus control from the viewpoint of gender equality an interim report]. [Report]. https:// www.gender.go.jp/kaigi/kento/covid-19/siryo/pdf/5-5.pdf

Klassen, M.L., Jasper, C.R., \& Schwartz, A.M. (1993). Men and women: Images of their relationships in magazine advertisements. Journal of Advertising Research, 33(2), 30-40.

Kunkel, D., \& Roberts, D. (1991). Young minds and marketplace values: Issues in children's television advertising. Journal of Social Issues, 47(1), 57-72.

Ministry of Health, Labour and Welfare. (2020, July). Reiwa gannendo koyou kintou kihon chousa [Basic survey of gender equality in employment management in 2019]. [Report]. https://www.mhlw.go.jp/toukei/list/dl/71-r01/03.pdf

Miyashita, M. (2020). Gendai nihon no raifusutairu to jenda: enjyou jidai kara kangaeru [Modern Japanese lifestyle and gender: Consideration of advertising in an age of 'flaming']. Journal of Studies on Humanities and Public Affairs of Chiba University, 40, 93-111.

Moony Promotion. [@moonypromotion]. (2017, 19 April). Muni ga okuru hajimeteno ikuji ni funtousuru mama ni okuru ouenka 'moms don't cry' Uemura Kana san no utagoe nimo chuumoku [A cheering song 'moms don't cry' by moony for a new mother who experienced for the first time taking care of children, the singing voice by Kana Uemura to watch] [Video attached] [Tweet]. Twitter. https://twitter.com/moonypromotion/status/854611454875508736

Nobeshima, A. (1998). Nihon no terebi koukoku ni okeru jenda byousha [Gender representation in Japanese television commercials]. Koukokukagaku, 36, 1-14.

Nergaard, K. (2020). Hjemmekontor og digitale løsninger. [Home office and digital solutions]. [Report]. https://fafo.no/images/pub/2020/300420-hjemmekontorfaktaflak.pdf

Pongsapitaksanti, P. (2008). Terebi koukoku ni okeru jenda to roudou yakuwari: nihon to tai no hikaku kara [Gender and working roles in television commercials: A comparison between Japanese and Thai television commercials]. Soshioroji, 52(3), 71-86.

Pozzan, E., \& Cattaneo, U. (2020). Women health workers: Working relentlessly in hospitals and at home. International Labour Organisation. [Report]. https:// www.ilo.org/global/about-the-ilo/newsroom/news/WCMS741060/lang--en/index.html

Statistisk Sentralbyrå. (2019). Fakta om likestilling [Facts about equality]. [Report]. https://www.ssb.no/befolkning/faktaside/likestilling

Statistics Bureau Japan. (2017). 2016 Survey on time use and leisure activities: Summary of results (QuestionnaireA). [Report] http://www.stat.go.jp/english/ data/shakai/2016/pdf/timeuse-a2016.pdf

ST-Corporation. (2019, 2 December). Senjyouriki ofisu hen 15 byou [Senjyouriki office version 15 minutes] [Video]. YouTube. https://youtu.be/BfSEsdQFxt8 
Strand, H.K. \& Schei, A. (2020). OsloMet-rektor Rice vil la kvinner komme tilbake på jobb før menn [OsloMet Rector Rice will let women return to work before men]. Khrono. https://khrono.no/oslomet-rektor-rice-vil-la-kvinner-komme-tilbake-pa-jobbfor-menn/485546

Suntory Beverage \& Food Limited. (2017, 19 March). Kurafuto bosu shin TV-CM 'Atarashii kaze' hen [Craft Boss new TV-CM 'a new wind' version]. https:// www.suntory.co.jp/softdrink/news/pr/article/SBF0518.html

Telenor. (1997). Løsninger for landet. [Solutions for the country] [Video]. YouTube. https://www.youtube.com/watch?v=sQP6Puh5VK4\&ab_channel=Teiprester

Telia. (2020, 9 April). The show must go online [Video]. YouTube. https:// www.youtube.com/watch?v=LiqyH9nPhCA

The Asahi Shimbun Corporation. (1975, 28 October). Tsukuru hito taberu hito 'sabetsu CM' yamemasu jyoseino kougi ni 'kousan' housou ha kongetsu kagiri'Danjyosabetsu' CM [Removing the 'descrimitation CM' - I'm the girl who makes it - I'm the guy who eats it. 'Surrender' to women's objection. It will be deleted by the end of this month - 'gender discrimination' CM]. Asabi Shimbun, 23.

The Suit Company. (2020, 18 May). Okcal SHIRT rimoto kaigi hen 15 byou [Okcal SHIRT remote meeting version 15 minutes] [Video]. YouTube. https:// youtu.be/125v6qo73Bg

Vaage, O.F. (2012). Tidene skifter: Tidsbruk 1971-2010 [The changing times: Time use 1971-2010]. Statistisk sentralbyrå. [Report]. https:/www.ssb.no/a/publikasjoner/pdf/ sa125/sa125.pdf

Wajcman, J. (1991). Feminism confronts technology. Polity Press.

Yoshida, K. (1998). Terebi komasharu no naka no kazokuzou no hensen [The transition of family images in television commercials]. In Y. Matsumura \& $\mathrm{H}$. Gössmann (Eds.), Media ga tsukuru jenda: Nichidoku no danjyo, kazokuzou wo yomitoku [Gender in making by media: Analysing gender, family images in Japan and Germany] (pp. 136-160). Shinyo Sha.

Øksnes, K. (2018, 9 July). I disse yrkene er fleksibel arbeidstid mest utbredt [In these occupations, flexible working hours are most common]. Pengenytt. https:// www.pengenytt.no/i-disse-yrkene-er-fleksibel-arbeidstid-mest-utbredt/ 


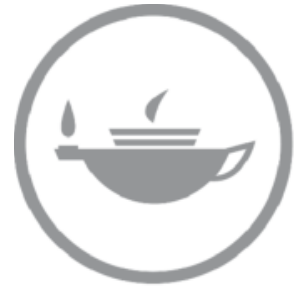

Taylor \& Francis Taylor \& Francis Group http://taylorandfrancis.com 


\section{Part IV}

Sexuality and reproduction 


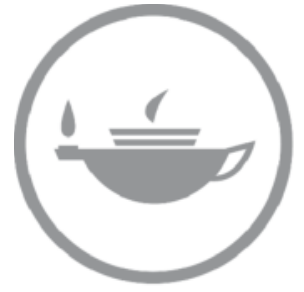

Taylor \& Francis Taylor \& Francis Group http://taylorandfrancis.com 


\title{
10 The struggle to belong: Trans and gender-diverse experiences in Japan and Norway
}

\author{
france rose hartline and Keiichiro Ishimaru
}

\section{Tracing the boundaries of gendered belonging}

Movements across the world advocating for the rights of transgender and gender-nonconforming ('trans') people have wrought immense cultural changes. These have occurred in tandem with an upsurge in trans political visibility and a growing push for gender diverse inclusion and recognition. The results have varied from context to context, materialising through new policies, practices and ideologies as well as bouts of governmental ambivalence and societal backlash. Two countries - Norway and Japan - present productive case studies for comparison given their divergent responses to trans rights advocacy. Norway has recently enacted numerous laws in response to the push for trans equality, while in Japan trans activists have met repeated resistance, making for slow progress. Though this would appear to give an irrefutable indication of how diversity issues are regarded in each country - with Norway demonstrating its reputed exceptionalism for human rights and Japan lagging far behind - we believe the actual situation is far more complex and deserving of a critical review. Indeed, our study reveals considerable convergence of the two contexts on the issues of sterilisation, gender recognition and trans belonging.

In this chapter, we reflect on the framework of the law/medicine/society triad in order to explore what trans rights means for gender diverse individuals in each country. We focus on how legal recognition of gender, or the lack of such, has intersected with the medical and social realms to shape gendered experiences of belonging. To do so, we draw on personal interview narratives collected from trans-identifying activists in Japan and Norway. These stories allow us to better understand how and to what extent gender diversity materialises and becomes viable within each sociocultural context. This comparison enables us to trace the boundaries of gendered belonging as they are formulated within each context.

We begin with a brief description of gender diversity and modern trans rights development in each country. Then, we outline the theoretical framework, method and methodology we have applied in our collection and analysis of the interviews. Finally, we present a discussion of the interview data from Norway and Japan. 


\section{Background: Setting the stage}

In both the Norwegian and Japanese contexts, three sites of tension emerged repeatedly in the interviews when discussing experiences and interpretations of trans rights - namely, the triad of society, medicine and law. Trans people's narratives of struggle uniformly invoke the power held by these three intersecting realms. The triad draws on the discourse surrounding Western interpretations of rights and empowerment, which forms the foundation of the globalising movement for transgender and gender diverse (trans) equality. This framework defines equality within society as based on recognition and respect for one's experienced gender identity as well as a sense of belonging, security and futurity. Law refers to the state or region's sanctioning of procedures, laws or practices that benefit and protect trans people. In the realm of medicine, trans rights can be characterised by unfettered, well-supported access to gender-affirming medical technologies and practices.

Interpreted loosely, this triad model can effectively be applied across the globalising trans rights movement, no matter the context. The movement's emergence coincided with the materialisation of trans-ness as a politically-, medically- and socially-indexed positionality. Cultural differences within and across national boundaries, however, also shape trans lives, embodiments and experiences. They do so in ways that do not always (or often) coincide with how trans rights and equality - or trans oppression and inequality - appear according to the Euro-Americo-centric model from which the trans movement has emerged. This calls for attending situationally and proportionally to the triad's power when making cross-cultural comparisons. In particular, this chapter considers the difference between Norway and Japan concerning the sterilisation requirement for legal gender change, and the resultant impact on experiences of societal belonging. Passing legislation to overturn this requirement has been central to trans activists' efforts around the globe over the past two decades, with varying results. With this in mind, the following gives an overview of how gender diversity has materialised and been institutionally formulated within each country since the late 20 th century.

\section{Norway}

Like its Scandinavian neighbours, Norway began implementing transspecific practices and policies relatively early from a modern perspective. The roots of gender diversity in Norway are largely traceable through medicine and law. Medical treatment for 'transsexualism' (the diagnostic term) became available in the 1960s through sex reassignment surgery. In the 1970s, this practice was formalised into an administrative procedure, whereby complete sterilisation would make one eligible for legal gender change. Though never codified in law, the sterilisation requirement for 
changing one's juridical gender would remain in place for decades until pressure from international and local human rights organisations tipped the scales. In 2016, Norway's Gender Recognition Act (GRA) took effect, following in the wake of the Sexual Orientation Anti-Discrimination Act 2013, which protects people from discrimination on the basis of gender identity and expression. Norway's GRA proved to be one of the most progressive of its kind. Based on the self-determination model, it allows one to choose to change gender without any medical intervention. No diagnosis or medical treatment is required; one need only to be a resident or citizen, and at least 16 years of age (or six years, with guardian consent) to request a change marker gender. Moreover, one could change back and forth infinitely, and there is no waiting period before the change takes effect. Once one has changed legal gender, they receive a confirmation of this change (which many call their 'papers' or 'letter'), and this can be used to change all personal identification documents.

The GRA stands out amongst the slew of acts which have speckled the world over the previous two decades. Most countries' versions of GRA require that one first receive a diagnosis of transsexualism or gender identity disorder (e.g., Sweden and Finland), will remain in their new gender (e.g., UK) and is of adult age (nearly all countries which have a GRA); some also require that one observe a 'reflection' period (e.g., Denmark). However, despite its remarkable qualities, trans advocates are quick to point out several shortcomings of Norway's 2016 GRA. To begin, one cannot choose a third gender or to opt out of the gender designation system entirely. Another shortcoming is that there has been no concurrent improvement in trans-specific healthcare, which continues to be monopolised by the state. The lack of second opinions or private options, combined with normatively exclusionary selection practices, has precluded a significant proportion of trans people from accessing the healthcare they need (Sørlie, 2015, 2018; Van der Ros, 2017).

\section{Japan}

While Japan has a long history of gender malleability (McLelland 2007; Suganuma, 2012), juridico-medical and societal attention to trans rights is relatively recent. The 1990s witnessed an LGBT 'boom' in Japan, during which queer activism and visibility grew exponentially for several key reasons - namely, the spread of internet access, the advent of HIV/AIDS activism (and the resultant spotlight on male same-sex sexual practices) and the destabilisation of hegemonic masculinity following the country's economic downturn (Robertson, 2017). In this period, trans issues took hold as activists began pushing for a place to belong outside of the entertainment and service industry. However, in line with the broader LGBT movement, trans activists' demands were deeply entrenched in Western cultural values. As a result, Japan's response was, and still is, reticent - though not as 
reticent as toward gay and lesbian rights demands. As in many non-Western contexts, trans people in Japan have made the most progress of the LGBT cohort. Gay and lesbian people have been seen as defiantly disrupting society by choice, whereas trans people - due to being ensconced in the medical system - have been seen as disabled people in need of treatment for rehabilitation into society. Thus, Japan began allowing sex reassignment surgery in the late 1990s, after which it followed the emerging Western trend in 2003 by passing a law which allows one to change legal gender in the family register (koseki) following irreversible sterilisation. This law, called Gender Identity Disorder Special Cases Act ([GID law], 2003), ${ }^{1}$ was regarded as quite progressive at that time by the LGBT community at large. Patients who have received the Gender Identity Diagnosis (GID) but have yet to be sterilised and change legal gender are provided a GID certificate as a stopgap by psychiatrists. This certificate confirms their diagnostic status, thereby making it possible to both change legal name and $\left(\right.$ ostensibly $\left.{ }^{2}\right)$ be better protected in various social situations, such as public restrooms. Moreover, in early 2018, the government began financially supporting those who choose to undergo medical transition by covering $70 \%$ of the surgical costs, though this is is precluded by any hormonal treatment prior to surgery. While governmental support in gender-confirming medical practices is undoubtedly positive, the trans people we spoke to describe a situation similar to that in Norway - namely, that the health practitioners prioritise the needs of those who present more gender and sexual normative narratives, lending to a high rate of exclusion.

The trans community has seen little legislative progress since 2003, as there continue to be no national provisions to protect individuals on the basis of gender identity or sexual orientation. Furthermore, despite a mounting pressure from human rights groups that culminated in a lawsuit challenging the sterilisation requirement in 2019, Japan's government has upheld the constitutionality of its GID law (Human Rights Watch [HRW], 2019). Promises to improve LGBT people's lives have seldom come to fruition. However, Japan's position as the 2020 Olympics host as well as the only G7 country to maintain its restrictive practices suggest that there may be changes afoot.

In the meantime, many trans people continue to live in stealth or with gendered appearances contrary to their legal identification. Societal awareness is limited, as representations of trans diversity outside of pathology are largely confined to the entertainment and service industry (McLelland, Suganuma, \& Welker, 2007), and thus do not allow much space for seeing trans as a deeper, overarching experience and embodiment. More and more advocacy organisations are being established to promote societal awareness and support trans people. General awareness around LGBT issues is undoubtedly growing but due to the lack of legislation protecting queer and trans people, as well as a cultural pressure to blend in, many trans people continue to feel disadvantaged and misrecognised. 


\section{Theoretical foundation}

This chapter applies a transfeminist framework of interpretation, which facilitates a critical gaze toward gender by dissecting non-normatively gendered experiences, embodiments, identities and desires. The 'feminism' of transfeminism contributes with a heightened focus on the intersectionality of compounding oppressions in shaping gendered subjectivities. Together they lay the groundwork for investigating the dynamic topography of genders and what possibilities for identification are opened and closed by existing social, legal and medical structures (hartline, 2020a, p. 73; Stryker \& Bettcher, 2016, p. 8). Transfeminism's approach to gender is special in that it avoids dividing the scope into cisgender and transgender, rather seeing gender as a valuational system that implicates all people to varying degrees across varying situations.

Gender, sex, identity and power have specific meanings in specific contexts at specific times, and part of a transfeminist approach is avoiding cultural imperialism by maintaining contextualisation (Connell, 2007; Sprague, 2016). The LGBT rights movement as Euro-American-oriented ushers in particular notions of what it means to be visible and empowered (Tudor, 2017). Formulating contextually relevant approaches to understanding LGBT experiences amidst the geopolitical shifts of globalisation is gaining momentum as a practice in many non-Western contexts by feminist and queer scholars (Massad, 2002; Suganuma, 2012). These approaches examine how diverse sex/sexual/gender identities, desires and behaviours are made viable (Connell, 2007).

From the macro-level, we apply the theoretical tool of the (cis)gender imaginary, which unearths the ways in which gendered possibilities are shaped by a particular sociocultural context (hartline, 2020a, 2020b). The (cis)gender imaginary is the space in which gendered norms are (re)produced and embodiments materialise or deteriorate. It distinguishes the viable from the monstrous, the desirable from the abject. (Cis)genderism remains the status quo even amidst ostensible efforts to undo it. Engaging with this concept points us away from focussing largely or exclusively on legislation and institutionally sanctioned practices, and toward the intricate weavings of the sociocultural fabric. Thus, it becomes feasible to understand how gendered experiences are shaped through affective modes of living and belonging, enabling a more balanced comparison between two differing national contexts.

From the micro-level, the research project is theoretically framed by the concept of 'belonging,' which describes the affective conditions of recognition, stability and participation (Aultman, 2018; Probyn, 1996) and the 'cognitive and emotional dimensions of identification and attachment' (Yuval-Davis, 2009, p. 4). Contrary to 'identity,' which implies a stable self, or 'citizenship,' which marks only the formal boundaries of membership, 'belonging' illustrates how the self metamorphoses in tandem with its 
environment by articulating the 'material cultural locality' that shapes the individual's subjectivity (Probyn, 1996, p. 5). As an analytical tool, it enables an examination of the individualised and communal projects that trans people undertake in responding to marginalisation.

\section{Method and methodology}

This chapter draws on interviews conducted with self-identifying activists in trans communities in Norway and Japan. In Norway, 15 individuals were interviewed: 12 of whom had changed legal gender following the enactment of the GRA in 2016, and three of whom who chose not to do so. These were single, one-on-one interviews, directed toward understanding how the individuals came to a decision about legal gender change and the impact of the decision on their lives. In Japan, 11 individuals were interviewed; this included seven individual interviews and one group interview with four people. Also, once-off, these interviews were aimed at understanding how the individuals experienced being trans or gender-diverse in Japan amidst a lack of protection and non-sterilisation-based recognition, including how they came to a decision about sterilisation and legal gender change. Both sets of interviews aimed to collect individual experiences of gender diversity and reflections on trans rights. The interviews in Norway and three of the interviews in Japan were conducted alone by co-author hartline; the remaining eight interviews in Japan were conducted together by the two authors, hartline and Ishimaru. In all cases, the services of a queeridentifying interpreter was on offer; in Norway, everyone chose to speak in English with hartline; in Japan, half the participants spoke in English and the other half in Japanese with the aid of either co-author Ishimaru or a hired interpreter. All interviews were transcribed in English by hartline.

The decision to focus on activist accounts was initially incidental. As an unintended consequence of the snowballing method as well as the tendency for interested interview subjects to be 'out' and active in the community, the vast majority of the interviewees in each context were trans activists and open about their identities in everyday life. Therefore, the representative quality of the data is limited in terms of what trans lives are generally like, since those who are openly trans are likely to have a markedly different interpretation and awareness of societal attitudes than those who are stealth or not yet out to themselves. We have chosen to take advantage of this skew in the data by drawing on the interviews as not just stories of personal experience but also as grounded insights into how institutions understand and help shape gender diversity. Having an activist background is valuable for becoming attuned to discourses around gender, as well as making one keenly aware of gender practices in general. With this distinction in mind, however, we also maintain vigilance when generalising activists' stories; there is a certain amount of social capital accumulated by being out and well-connected with others in the trans community, as well as cultural 
capital in having access to more diverse knowledge around trans rights within and beyond the national context. We therefore contextualise the selected quotes in order to give depth to each participant's perspective.

\section{Discussion}

Our point of departure in exploring the narratives is the experience of legal gender change, as trans-specific legislation is the biggest difference between Norway and Japan when it comes to trans rights. As described in the Background section, Norway began allowing for legal gender change without sterilisation or diagnosis in 2016, whilst in 2019 Japan upheld the constitutionality of its GID law, 2003, which requires irreversible sterilisation for legal gender change. In both Norway and Japan, the experience of legal gender change highlights the character and power of the state. Norway's history of social democracy and welfarism and Japan's hierarchical structure and deference to authority, both lend the state and its institutions a particular credence regarding the legitimacy of gender expressions, embodiments and identities. The following discussions draw on the interview data to focus on how legal recognition of gender, or the lack of such, has intersected with the medical and social realms to shape gendered experiences of belonging. Participants' reflections on three key issues guide the discussion: 1. Attitudes toward sterilisation (as a transitioning practice and as a social and/or legal requirement); 2. Gender-diverse un/ acceptance across institutions; 3 . Achieving a sense of belonging as a trans person. To provide context to the quotes, each participant's stated gender identity, age range and legal gender are provided (in this order).

\section{Attitudes toward sterilisation}

\section{Norway}

None of the Norwegian participants had undergone sterilisation at the time of the interview, and most described it as unnecessary, even counterproductive, for their own transition journeys. Several felt frustrated that the state waited so long to make legal gender change possible without sterilisation. Lene (non-binary, 30s, F) asked, somewhat rhetorically, "Why wasn't this [option] available sooner? Why do we need to bureaucratise people's bodies? Pathologize bodies?' Anders (transman, 20s, M) shared this sentiment, adding that he was glad he could now avoid sterilisation. He had believed in the past that it was right for him, but eventually he realised that it was not that he was 'born in the wrong body,' but rather that society simply did not 'understand [his] body.' 'Being male,' he explained, 'doesn't necessarily mean cis male, with a flat chest, penis, beard, muscles, etc.' Becoming legally male without sterilisation, for Anders, had 'given back sovereignty over [his own] body.' 
Some of the Norwegian participants were still pursuing sterilisation despite the GRA's enactment. Ana (woman born in the wrong body, 30s, F) shared that while she felt more confident with her new legal gender, she did not feel free to behave exclusively like a woman because she had not yet completed her gender-affirming medical treatments. As an example, she explained that she still would not shower with other women at the gym, even though she could, if needed, justify her presence with documentation of her legal gender change. Her concern was about not imposing on people around her:

I don't know, maybe for others it's different, but there are some things I feel that you can't do if you still don't have the right body. Not only because you can't, but you shouldn't. You shouldn't be rude to other people, you should respect them. (...) Having the papers [confirmation of legal gender change] is not enough.

This perspective was shared by Bente (transgender woman, 60s, F). While finally getting her female identification had been a 'victory' and helped her be more authentic with herself and others, she still felt incomplete due to having been denied trans-specific healthcare. She explained that every time she undresses in front of the mirror, she would see someone who was 'a transgender, not yet a real woman.' For both Ana and Bente, genderaffirming treatment via sterilisation was a critical part of their transition, and legal recognition could not compensate for the lack of physical shift.

\section{Japan}

Attitudes amongst the Japanese interview participants are quite negative toward sterilisation. This is not surprising given their activist status, but this stood in stark contrast to the Norwegian collective. The fact that sterilisation was still a requirement for legal gender change, rather than simply an option for one's transition process, likely made it feel more oppressive to them. Discussions on undergoing sterilisation arose only in relation to the need for security, particularly regarding employment. Mariyo (woman, 30s, M) said that although she did not want to, she may have to undergo sterilisation in order to procure a stable job: 'Being unemployed, I feel excluded from society, and I think it requires a legal gender change to change that.' Yukihiko (man, 30s, M) had chosen to be sterilised in young adulthood in order to secure employment, but it was now a decision he felt he should not have made:

I didn't really want to remove my ovaries, because I'd never seen them, they're not visible. But it was really difficult for me to start working as a man with the female marker, so I had the surgery. At that time, I didn't think it was a big deal. I thought, 'Well, as long as I change my legal 
gender, a lot of things will solve itself.' But that was not so. (...) It took away my ability to produce children. (...) Now, if I met a man that I love, then maybe I would have had a child. And now I can't get legally married, unless the law changes, because I'm gay and men can't marry. So, it's a bit like, 'Well, what did I do this for?'

Several other participants had chosen to avoid changing their bodies, not just to preserve function but also integrity. Uzuki (woman, 40s, M) had always opposed the GID law, saying that it unduly pathologizes transgenderism as a disability and thus compels people to change their bodies for society:

Getting operated on and getting surgery is a very personal issue for me. Surgery is not a social issue. You don't have to have surgery to be socially accepted. (...) I don't want to do it just because I am told to. (...) I want to be an example for others.

\section{Gender-diverse un/acceptance}

\section{Norway}

In reflecting on their experiences of acceptance, the Norwegian participants' stories varied widely. Some felt generally empowered in Norway, particularly following the GRA's enactment. The protection afforded by the GRA was clear in nearly all the participants' narratives. Torill (woman/transperson, 60s, F) said that after changing legal gender, she no longer worried about passing: 'I'm not afraid at all anymore, I'm quite brave.' As an activist, she has felt more able to speak openly about being a 'woman living in a male body.' When people challenge or question her, she tells them, 'It doesn't matter that you don't understand, because it is not your problem. I am the only one who knows who I am.'

However, many felt that Norway continues to disregard many of trans people's needs, as exemplified by the binary requirement. Lene (non-binary, $30 \mathrm{~s}, \mathrm{~F})$ felt there was no space for her to be genuine, since society and the state validate only binary-identifying people. She had changed her marker from male to female to match her socially read appearance, but she still felt misplaced:

I don't appreciate having binary ideals forced onto me. (...) You can't actually live a good or happy or productive life under any of those circumstances where society or the system is pressuring you into something you're not feeling comfortable with....For the general view of society, the binary does not represent reality at all. 
Sebastian (transman/queer, 30s, F) shared this feeling, thus why he had not changed legal gender despite his masculine appearance:

I feel sort of like [changing legal gender] has become an obligation just because I pass as a man and it is an option now. How is that different from being told before what gender I had to be? (...) I'm worried that if I change my gender marker, then I'll just be another typical guy in the world, and my whole history of fighting for acceptance and coming to terms with myself and feeling pride will be erased in the eyes of society. I want to live as a transman, not just a man, but we have to choose one presumably cisgender category or the other.

Sebastian also noted his frustration with the ostensible progress that Norway has made for trans rights, imploring, 'Let's not pretend this is the final stop on the rail line toward trans equality. Far from it. The train has just barely started moving.'

Furthermore, many of the transwomen (though none of the transmen) in the Norwegian cohort expressed a continued fear to enter private spaces. They did not feel that having a legal gender marker would necessarily protect them against rejection by others, particularly in gender-segregated spaces. In line with Ana's above-quoted refusal to shower at the gym before completing her medical treatment, Bente (transgender woman, 60s, F) did not yet dare use women's public bathrooms. She always opted for the handicapped toilet, for fear of being scolded by those who presumably deserve to be there. To be rejected in such an intimate space by 'real women' would negate her femininity to an indelible degree. Lene (nonbinary, 30s, F) also worries about rejection due to her anatomy, describing the possibility of getting into 'gender trouble.' Even though she passes as a woman, the stress of being discovered as 'not truly female' proves too trying.

\section{Japan}

The struggle to have one's trans or gender-diverse identity validated through the state and society was also a recurring element in the Japanese participants' narratives. Several spoke of the 'façade' of acceptance in Japanese society, noting the disjuncture between appearance and reality. For example, Sayae (woman, 20s, M) explained that the lack of violence towards trans people does not indicate respect:

No one has ever said to me, 'I hate you, I don't like you.' Japanese people never say when they don't like someone, they don't say it directly. [People] only say good things. It's not good. (...) We are never killed, we are never raped. But it doesn't mean that we are happy. (...) We should speak up more, so people know. 
Jinya (man, 30s, F) expanded on this, highlighting the in-between status of trans people from a legal perspective - not quite prohibited but not quite allowed:

We LGBT people are not criminalised, so we don't get arrested in Japan, but when we have to depend on the government, we aren't recognised, so we can't really get the same support that other people do. And that means that we are second class citizens. So that's really hard for us. (...) I don't feel safe living in Japan.

Because gender identity disorder (GID) is regarded as an unfortunate, but curable, illness in Japan, the apparent respect for trans people is conditioned upon the trans person's intention and desire to undergo sterilisation. For those who do not undergo it, genuine acceptance is difficult to come by, not only in broader society but also with the trans community. There is a hierarchy of belonging that ranks those who identify as the medical term 'GID' above those who identify as the Western term 'trans.' Broadly put, the former seek to undergo sterilisation to become 'typically' sexed and pass within the binary, while the latter seek to challenge the binary by avoiding sterilisation. The divisiveness of the trans political landscape is of course not unique to Japan, but it may be amplified there due to limited knowledge on gender variance beyond small activist circles. The participants described the situation as improving, but still they worried that the sociolegal emphasis on passing was pressuring uninformed youth to pursue measures they may regret later, as captured for example in Yukihiko's story above. The limited representation of trans people proves problematic for those just beginning to explore their identities. When Keito (man, 30s, F) was young, he had thought undergoing complete transition was necessary for acceptance because there were no gendernonnormative role models to look to for alternatives. As an adult activist, he had learnt to be proud of his transness and now worked with others to promote alternative ways of transitioning. He explained why:

Japanese people think trans people are very poor and discriminated against and have poor health. Many people look down on trans people. They don't realise that trans people can be happy. (...) They discriminate against trans people who aren't normal, especially outside the big cities where there is no concept of diversity. (...) Trans people internalise this discrimination.... and think they must choose to be either a man or woman. (...) We need to show [people] that we can be happy without being normal. 


\section{Achieving a sense of belonging}

\section{Norway}

In their personal projects for securing a livable life, several of the Norwegian participants found that passing fully as a man or woman provided them with a sense of belonging since their internal self is validated through acceptance as legitimately situated within the gender binary. The new identity marker, for example, was a stamp of approval from the state that could be deployed in difficult social situations. Camilla (woman, 20s, F) had always identified as a woman despite not always passing, but with her new legal marker, she saw herself as 'real female, a born girl.' She now felt she could improve her life by demanding more respect from the state welfare system and her employer, both of which she believed had treated her poorly for being trans. Dolores (woman, 50s, F) also felt validated by legal gender change, but since she had been turned down for much-wanted medical treatment, she found herself figuring out how to live with male genitalia. She strove to take pride in her status as a 'woman with bollocks':

I like the double meaning of it. There's another way to see it. A woman with bollocks is standing and fighting for herself. She has got a mouth and she is there for herself and for her beliefs. She's not bad, but she can be brutal, standing up for her mates and her kids, forever.

After changing legal gender, Dolores had begun to feel more secure in herself, even returning to some of the masculine activities and clothing she had given up in trying to be accepted as a woman. She took pleasure in being able to forego femininity in her hobbies and expression but still be a 'real woman.'

For some of the Norwegian participants, however, there continued to be a disconnect between self and the society/state, despite progressive legislation and relatively low reports of trans-directed discrimination. It became particularly clear here how underlying cisgender norms were still shaping subjective experiences of the gendered self, delimiting possibilities for embodiment. Ingrid (transwoman, 30s, M) had decided against changing her legal gender from male to female because she did not feel she passed in everyday life. Having been turned down for trans-specific healthcare, she found herself lingering in a precarious position as she was unable to afford gender-affirming treatment on her own. Ingrid explained that changing legal gender could actually make her life more difficult, as she would lose the ability to resume a masculine role when safety and security were at stake, such as when travelling abroad or applying for jobs. She asked, 'What is the point of changing my legal gender if society still doesn't see me?' While becoming legally female may well compel institutional and social actors to openly regard her as a woman, Ingrid believed that it would 
not necessarily compel their respect. As demonstrated with the issue of intimate spaces discussed above, societal attitudes are not fully subject to the state's approval, so trans people must navigate public life carefully.

\section{Japan}

Most of the Japanese participants were actively engaged in LGBT organisations, which provided them with a space for (co)validation and the power to promote personal causes. Across the interviews, there was a tendency to eschew complete institutional involvement in their transition processes, preferring rather to remain radical to some degree. For instance, Naoto (man, 30s, F) spoke of his decision to not take testosterone, even though he would have enjoyed the physical changes and passing as a man. His partner was a ciswoman, so he worried that he would be read as a cis-heterosexual male. He thus preserved his queerness through this act of bodily defiance, by claiming a belonging to masculinity whilst rejecting its principle standards. Okito (man, 50s, F) shared a similar approach, citing his desire to live outside the binary - 'after 48 years inside it' - as a reason for not having pursued hormone treatment. He considered the medical transition process to be only one of many ways to grow into oneself, and he found meaning in being an example of this:

We think of trans as 'transing' - crossing - the boundary, but I like to think of it as 'transcending' gender. If I stay in this transcending state, and not choose one or the other, then maybe it will help other people do the same. People, all people, need to be more self-expressive and self-assured. Marriage, children, gender, hormones, operation - everything should be a choice, and not be enforced. (...) We need more freedom of spirit so we can choose.

Sayae (woman, 20s, M) also believed that the government was trying to be too involved in governing trans lives, but she was personally invested in passing socially. Having been on hormones for two years, she was appearing more feminine, which had made her life simpler:

I care about legal gender, but more than legal gender, I care about whether I look like a woman. That's what's important for friends and parents. So, if I look better, my parents stop caring, stop wanting to make me stop [being trans].

Sayae felt more accepted amongst her loved ones when she did not overly challenge their notions of gender identity. She did not feel further medical intervention is necessary for her, which she attributed to her privileged position. She was employed by an international company that allowed her to identify openly as a woman despite being legally male. Moreover, she 
was fluent in English and was involved in both local and international trans activism, which had vastly expanded her knowledge of gender diversity. Nonetheless, she did not feel comfortable enough to be openly trans beyond her work and home life. It was important for Sayae both fit in with society as well as to be a representative for diversity. As seen amongst the other Japanese participants, the degree to which each positionality was sought depended upon a mix of desire and ability.

\section{Conclusion}

In this chapter, we have explored the struggles faced by trans people in both Norway and Japan in order to highlight some of the commonalities and differences in how trans belonging is understood and experienced. We found that in both Norway and Japan, the individuals we interviewed generally expressed significant disappointment with the status quo of trans rights. There was a pervasive sense of non-belonging - nationally, socially, and, for most, psychically and physically. The maintenance of the cisgender standard, via the (cis)gender imaginary, became evident again and again through the internalisation of incompleteness or misrecognition by most of the participants. They spoke of their repeated encounters with uncrossable boundaries and the tension it caused with their senses of self. In reconciling the tension and carving spaces of belonging, some sought to find pride and purpose in these radical positionalities, whilst others strove to align themselves better with societal expectations in order to enhance their security and life quality. Several had occupied both ends of the spectrum during their transitions, drifting across due to circumstance and desire.

Initially, we had anticipated that the stories from our Japanese participants would demonstrate a greater degree of non-belonging than those of our Norwegian participants. However, the difference was curiously narrow, leading us to speculate that it may be in part due to culturally conditioned expectations surrounding institutional support. We suspect that the promise of the Norwegian state (both implicit and explicit) to protect its citizens through uniquely progressive legislation and practices, particularly regarding gender equality, has imprinted upon trans people's expectations of the state in such a way that any dissonance between one's felt reality and the national imagery of equality becomes amplified, leading to a sense of frustration - and even personalised failure (hartline, 2020a). Meanwhile, the traditions of gender segregation and inequality in Japan have long obliged trans people to find alternative modes of coping with misrecognition and limited protection; with little anticipation of state support for diversity, it has been necessary to claim livable spaces outside state-endorsed boundaries of inclusion. 
This difference was especially highlighted in how the two groups regarded the repeal of the sterilisation requirement. While in Norway the participants expressed the feeling of 'det skulle bare mangle' ('it is now as it should be') after the GRA's passing, many of our Japanese participants, despite being trans rights activists, were not even aware that the sterilisation requirement had been recently upheld as constitutional following a lost lawsuit in Japan's supreme court ('Japanese transgender man,' 2019). Putting aside the fact that a new act tends to make bigger waves than a lost lawsuit, it was clear that while the Norwegian participants strongly related their journeys to the state's involvement, many of the Japanese participants considered localised participation, community and employment security and small-scale redress to be more important for improving their situation. Relying on community (which one can help shape) over the state and its institutions can make belonging more achievable, which may explain why the Japanese participants did not seem to be struggling a great deal more than the ones in Norway. However, this is a benefit only so long as one has sufficient access to a like-minded community. This is why it is necessary to read the Japanese activists' narratives with a critical lens, as they are underwritten by a degree of privilege likely to be lacking from many, if not most, trans people's stories.

In this chapter, we have sought to provide insight into the limitations and experiences of trans people in Norway and Japan in order to demonstrate the nuanced contextuality of gender diverse belonging. However, this is a topic that deserves continued investigation. For further study, we suggest that interviews be carried out with nonactivist and non-urban gender-diverse individuals in both Norway and Japan. Exploring how gender variance is experienced and addressed among those who are not involved in the trans rights movement would be highly beneficial for further investigating the limitations of institutional support in each country.

\section{Notes}

1 Law 111, or the Gender Identity Disorder Special Cases Act. This law has been challenged by human rights activists on multiple grounds, including the requirement for patients to be diagnosed with gender identity disorder, to be at least 20 years old (thus disallowing children or youth), to have no children under 20 years, to be not married (thus forcing married patients to divorce), and to undergo extensive and unnecessary surgery to become sterilised (Human Rights Watch [HRW], 2019).

2 Several of the interview participants shared that they believed the certificate offered no real protection from discrimination when using public restrooms without 'passing' as one's personal gender identity, since the general public does not understand the certificate's significance and would not accept it as justification. Almost none of the participants said they used their certificate at all, aside from when attending medical clinics or changing their legal name. 


\section{2 france rose hartline and Keiichiro Ishimaru}

\section{References}

Aultman, B.L. (2018). Feeling as knowing: Trans phenomenology and epistemic justice. [Doctoral dissertation, City University of New York]. CUNY Academic Works.

Connell, R. (2007). Southern theory: The global dynamics of knowledge in social science. Allen \& Unwin.

hartline, f. (2020a). The (trans)gender equality paradox: Challenging Norway's 2016 law on gender recognition. [Doctoral dissertation]. Norwegian University of Science and Technology].

hartline, f.r. (2020b). Exploring the (cis)gender imaginary in the Nordic Region. Journal of Gender Studies, 1(23).

Human Rights Watch [HRW]. (2019). 'A really high hurdle': Japan's abusive transgender legal recognition process. [Report]. https://www.hrw.org/report/2019/03/19/ really-high-hurdle/japans-abusive-transgender-legal-recognition-process

Japanese transgender man loses appeal against enforced sterilisation. (2019, 24 January). SBS News. https://www.sbs.com.au/news/japanese-transgender-manloses-appeal-against-enforced-sterilisation

Massad, J. (2002). Re-orienting desire: The gay international and the Arab world. Public Culture, 12(2): 361-385.

McLelland, M., Suganuma, K., \& Welker, J. (Eds.). (2007). Queer voices from Japan. Lexington Books.

Probyn, E. (1996). Outside belongings. Routledge.

Robertson, J. (2017, 28 February). Japan's gender-bending history. University Wire [newspaper]. University of Michigan.

Sørlie, A. (2015). Legal gender meets reality: A sociolegal children's perspective. Nordic Journal of Human Rights, 33(4): 353-379.

Sørlie, A. (2018). The right to trans-specific healthcare in Norway: Understanding the health needs of transgender people. Medical Law Review, 27(2): 1-23.

Sprague, J. (2016). Feminist methodologies for critical researchers: Bridging differences (2nd ed.). Rowman \& Littlefield.

Stryker, S. \& Bettcher, T.M. (2016). Introduction trans/feminisms. TSQ: Transgender Studies Quarterly, 3(1-2): 5-14.

Suganuma, K. (2012). Contact moments (vol. 1). Hong Kong University Press.

Tudor, A. (2017). Dimensions of transnationalism. Feminist Review, 117: 20-40.

Van der Ros, J. (2017). The Norwegian state and transgender citizens: A complicated relationship. World Political Science, 13(1): 123-150.

Yuval-Davis, N. (2009). Identity, citizenship and contemporary, secure, gendered politics of belonging. In A. Denis, \& D. Kalekin- Fishman (Eds.), The ISA handbook in contemporary sociology: Conflict, competition, cooperation (pp. 29-41). SAGE Publications. 


\section{A matter of gender (in)equality? Public discourses on declining fertility rates in Japan and Norway}

Guro Korsnes Kristensen and Yukari Semba

\section{Declining fertility rates}

The stable production of healthy new generations is the most important resource of any collective of people, including the nation. Hence policy makers, experts and the general public pay close attention to the national fertility rates, ${ }^{1}$ expressing worries if they appear too high or low. This paper sets out to explore the triangle of fertility, nation and gender, focusing on the cultural meanings that are ascribed to the notion of declining fertility rates when this phenomenon is discussed publicly in Japan and Norway.

In the 20th century, the world population increased from 1.5 to 6.1 billion, and according to the latest United Nations (UN) population projections, the world's population will be at 10.9 billion in 2100 (United Nations [UN], 2019). Parallel to this, climate change has become a global worry, and in this regard there has also been an increasing recognition of the profound problems caused by global population growth (Clarke \& Haraway, 2019). Whereas the fertility rates in the so-called Global South remain above the replacement rate, they have been decreasing in many countries around the world in the last three decades (United Nations, 2019). In Europe (49 countries and the Channel Islands), the average fertility rate was 1.61 children per woman in 2019, which is far below the 2.1 replacement level that the UN holds as standard for population regeneration (United Nations, 2019). ${ }^{2}$ In Asia, several countries are facing the same situation, and, as in Europe, they recognise this as a serious problem.

Both Japan and Norway are seen as rather typical examples of their respective regions when it comes to fertility numbers and their evolution in recent years. In Japan, the fertility rate declined from 2.14 in 1973 to 1.74 in 1981, 1.57 in 1989, and 1.36 in 2019 (The Ministry of Health, Labour and Welfare [MHLW], 2020). In Norway, there was a marked decrease in the fertility rates from the mid-1960s to the mid-1980s (from 2.98 in 1964 to 1.66 in 1984) (Ravn, 2005). Whereas the fertility rates continued to fall in most European countries throughout the 1980s and onwards, they started to rise again in the Nordic countries. In 2009, the Norwegian fertility rate was 1.98; however, it has dropped again since then. As can be 


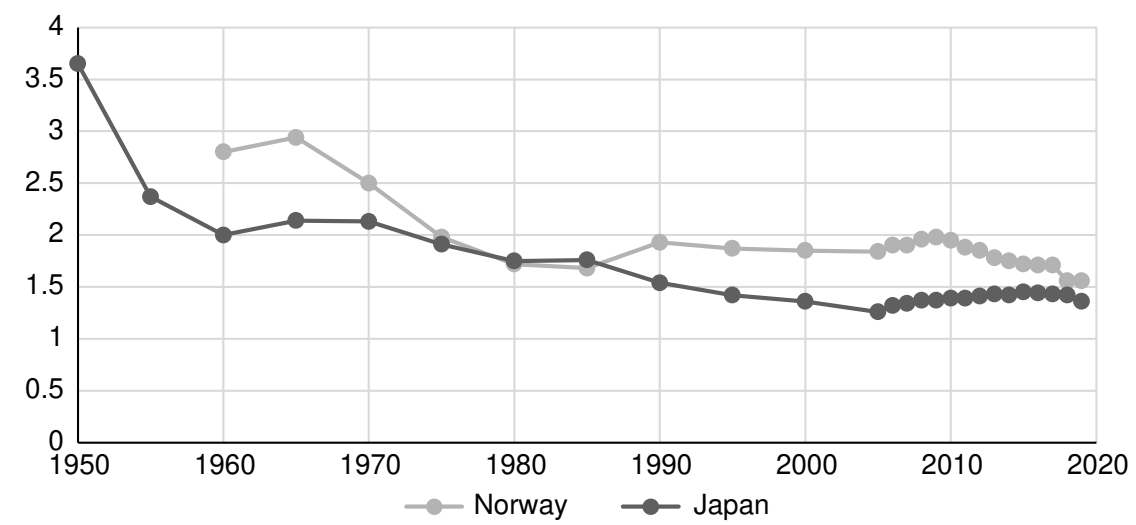

Figure 11.1 Total fertility rates in Japan and Norway.

Note. Source: Japan: IPSS, 'Figure 4-5, Total Fertility Rate of Major Developed Countries: 1950-2018,' Population Statistics of Japan 2020. http://www.ipss.go.jp/syoushika/tohkei/ Popular/P_Detail2020.asp?fname=T03-09.htm Norway: (1960-2008) The World Bank, https://data.worldbank.org/indicator/SP.DYN.TFRT.IN?locations=NO(2009-2019) Statista, https://www.statista.com/statistics/611702/fertility-rate-in-norway/.

seen in Figure 11.1, the actual fertility rate stood at 1.48 in 2020 (Statistics Norway, 2020).

Even though the fertility rate of Japan and Norway are rather similar today, the structural, political, social and cultural factors surrounding them are somewhat different. Despite a decreasing fertility rate, Norway still has a growing population $(0.44 \%$ in 2020$)$, due to immigration and a long history of rather high fertility rates (Statista, 2021a). Japan, on the other hand, has a negative population growth due to limited immigration and a longer history of low fertility $(-2.1 \%$ in 2019) (Statista 2021b). Thus, while both countries are experiencing the phenomenon of an 'ageing population,' it is far more prevalent in Japan.

Intrigued by this complex of similarities and differences, we examine the ways in which national fertility rates, and more specific declining fertility rates, are presented and discusses publicly in the two countries. We pay special attention to what kinds of explanations and measures are launched, and how they relate to and produce specific understandings of gender and nation. We ask: What characterises the public debates about fertility rates in the two countries, and what similarities and differences exist between them?

\section{Theoretical perspectives}

To conceptualise the cultural/public meaning in regard to declining fertility rates and explore the intersections of reproduction, gender and nation, we have found inspiration in Nira Yuval-Davis' theorising of the relationship 
between gender and nation as it unfolds in various kinds of population politics (Yuval-Davis, 1997). According to Yuval-Davis, there are three hegemonic discourses in relation to national reproduction: The 'people as power' discourse, the Malthusian discourse and the eugenics discourse.

The people as power discourse is characterised by the idea that the nation's future depends on continuous population growth, and that this can be ensured both through biological reproduction and through immigration. For women, this way of thinking may mean that, for example, after a natural disaster, war or other crisis, there may be extra pressure for increased reproduction. In this context, not having children can subject women to criticism, but it can also be an effective way of resisting national projects and government policies.

In the second discourse, which Yuval-Davis labelled Malthusian, uncontrolled population growth is understood as a serious societal problem, and responsible policy should be aimed at limiting further growth. This discourse has been criticised for making poor countries and poor people responsible for global problems, and for stimulating and legitimising population politics that are violating peoples,' and in particular women's, reproductive rights (Hartmann, 1995).

The focus of the third discourse, eugenics, promotes population 'quality' over quantity. Quality is achieved through, for example, reward systems that encourage only selected people to have children. Yuval-Davis also notes that eugenics discourse legitimises the use of coercion as a strategy for effecting reproduction. This way of thinking about reproduction and population is highly controversial, and several researchers have shown that eugenic discourses typically are targeting poor women and discouraging them to have more children and thus reproducing power hierarchies (Hartmann, 1995).

\section{Method, data and analytical tools}

The data material consists of white papers, political statements, newspapers and other news media items published in both Japan and Norway between 2013 and 2021. The texts are sampled through systematic searches in national media databases. In Norway, we applied ATEKST, which includes all print and online Norwegian newspapers. In Japan, we used Bunzō II (Asashi Shimbun Database), Yomidas Rekishi-kan (Yomiuri Database Service), Nikkei Telecon (Nikkei Shimbun Database), Maisaku (Mainichi Shimbun Online) and Sankei Shimbun Databases (Sankei Shimbun), which are the databases of the five biggest national newspapers in Japan. In addition, we used news articles that we found through internet searches with keywords. When conducting these database searches, we applied the Norwegian and Japanese terms for population, fertility, fertility rate, reproduction, population politics and declining birth rate. 
We focused on fertility discourse in public media because we see these as integral resources for understandings and meanings in this field (Arnoldi, 2005). Our analysis reveals the kinds of information on fertility confronting the public in both countries as well as the political ambitions integrated in that discourse. We do not see media merely as reproducers of reality, but also as producers. The media is instrumental in defining what is seen as normal, acceptable and aberrant, what deserves and needs special attention, what is taken for granted, and so on. Moreover, media sets the political agenda, and various political actors use media as a vehicle for communication. Thus, we argue that it is important to analyse the ways in which cultural meaning production is represented, developed and formed in and by media.

Our position as researchers in this field is neither that of pro-natalism nor anti-natalism. Rather, we take an explorative approach to the public debates and the meanings expressed there.

\section{Japan: Struggle regarding declining birth rate and strategies to raise fertility rate}

An important area of discussion in regards to the Japanese fertility relates to a narrative of national crisis. On 4 October 2019, Prime Minister Abe made the policy speech at the 200th session on the Diet, and he stated 'we will squarely address the declining birthrate, which should also be called a national crisis [kokunan]' (Abe, 2019). When Abe came to power in 2012, he mentioned that one of his priorities was to increase the number of daycare centres so that mothers can return to the workforce ('Number of newborns,' 2019). However, under the Abe administration, which lasted seven years and eight months, TFR continued to decline every year and reached a record low 1.36 in 2019. It might show that the policy has not been effectively implemented, and it is still hard for young people to balance work, family and childcare while having children. In February 2016, one blog attracted attention in Japanese society. It was the anonymous blog entry posted by a woman who had not been able to get her child into day care facilities. The title was 'My child wasn't accepted for nursery school. Die Japan!!' (Hoikuen ochita Nihon Shine!!) ('Parents protest,' 2016). However, Abe ignored it because it was an anonymous blog post. The entry spread over the Internet, and about 100 parents whose children were refused entry into childcare facilities lunched a protest in front of National Diet Building in Tokyo holding up signs saying 'It was me,' and a website collecting signatures in support of introducing a better childcare system had collected more than 20,000 signatures within a month ('Parents protest,' 2016). The number of children waiting for entry into nursery schools is on decline by the government's childcare support program 'kosodate anshin puran,' however it is still a serious issue in Japan (Hoiku no oshigoto report, 2019). 
Several issues have been identified as leading to a declining birth rate in Japan. In addition to the lack of day-care facilities cited in the blog post above, these include delayed marriage, late-in-life pregnancy, the rising cost of child-rearing and women's increased roles in society and the workplace (Castro-Vázquez, 2017; The Economist Intelligence Unit, 2018).

Cultural value in Japan is given to families comprising a married couple with children. This makes marriage first and foremost a prerequisite for childbearing. However, as scholars have previously noted, women in Japan have become increasingly less likely to get married or bear children in the last decades. This is due to the potential difficulty of maintaining a worklife balance within the traditional gender framework that expects women to prioritise their families (The Economist Intelligence Unit, 2018). In addition, women fear that if they have children outside marriage, they will be socially stigmatised and faced with enormous financial challenges. For example, they typically find themselves in low-paying part-time employment and must live on incomes below the poverty line (Lezott, 2020).

Japan has the highest percentage of the population aged 65 and over in the world. Indeed, as of September 2019, this ageing rate reached a record high of $28.4 \%$. The National Institute of Population and Social Security Research (IPSS) estimated that the rate of population aging will continue to increase, with $30 \%$ and $35.3 \%$ of the population being aged 65 years and over by 2025 and 2040, respectively (Statistics Bureau of Japan, 2019). In general, societies with declining birth rates and ageing populations experience labour shortage, which exerts long-term negative social impacts on the economy (Atoh, 1994). In 2014, the Japanese labour force was 65.87 million, but it is estimated to decrease to 56.83 and 37.95 million by 2030 and 2060, respectively (Cabinet Office, 2018).

MHLW as well as local governments have devised various measures to mitigate the negative consequences of a declining birth rate and to maintain social security. In the 1990s, the Japanese government first initiated and expanded family planning policies and programs that sought to provide monetary assistance directly to parents. This took the form of child allowances and steadily expanded provisions for parental leave and subsidies for childcare services (Tsuya, 2017). In 2010, the government introduced four major policies to support young people's fertility, which centred on pregnancy, childbirth, child-rearing and work-life balance (The Economist Intelligence Unit, 2018).

Among the policy initiatives meant to deal with the declining birth rate, the Japanese government has provided people suffering from infertility with financial and psychological support for taking infertility treatments. The criteria for receiving this support were relaxed first in 2006, then to a greater degree in 2013, making more couples eligible. However, the financial cost of assisted reproductive medicine still overwhelms many infertile couples because the Subsidy for Specific Infertility Treatment Expenses by the government does not cover all financial cost of intrauterine 
insemination, in vitro fertilisation and intracytoplasmic sperm injection. However, in 2020 Prime Minister Suga stated, 'We will swiftly make public health insurance cover infertility treatments and eliminate income thresholds on eligibility. Until such insurance coverage becomes available, we will broadly expand the subsidy measures currently in place.' Furthermore, MHLW sought additional funding from the government in its 2021 budget request to boost subsidies for couples receiving infertility treatments until insurance can cover these treatments ('Itten Toppa,' 2020).

Although the Japanese government has implemented policies intended to support families' fertility and boost the declining birth rate, these polices have failed to produce the desired result. Thus, the fertility rate remains well below replacement levels.

\section{The difficulties of raising children for women in Japan}

Another quite visible area of debate which relates to the Japanese fertility rate is the position of women in society, and, in particular, the difficulties Japanese women face when having children. According to the Japanese National Fertility Survey conducted in 2015, married couples reported that the average number of children they want was 2.32. However, the actual average number of children per family in 2015 was 1.94. IPSS's survey presented the following reasons for them being unable to achieve their desired number of children: 'It costs too much to raise and educate children' (56.3\%), 'I strongly dislike the idea of bearing children at an older age' $(39.8 \%)$, 'I want to have a child but cannot conceive' $(23.5 \%)$, 'I cannot mentally or physically bear the burden of childbearing anymore' (17.6\%), 'I cannot because of health reasons' (16.4\%), 'It would interfere with my job or business' (15.2\%), and 'My house is too small' $(11.3 \%)$ (National Institute of Population and Social Security Research [IPSS], 2017).

The following quotes, derived from newspaper articles, reflect the difficulties Japanese women face when having children. The first three statements show that raising and educating children is extremely expensive:

It costs too much to raise a child. I often hear people around me say that it is impossible for them to raise three children. My husband and I are both full-time employees, but we don't even have a house, so we decided that having only two children is realistic for us. (A woman in her 40s living in Tokyo; ['Fōramu: Tanomuyo,' 2020])

We have a one-year-old child and I am on childcare leave. My husband is a non-regular employee, and the amount of work he receives has been reduced drastically. This has had a serious impact on our household finances. (A woman in her 30s living in Aichi; ['Fōramu: Tanomuyo,' 2020])

Ideally, we would like to have one more child. But I want to respect our son's desire to 'learn,' so we want to be able to pay tuition and academic 
fees in the event that he wants to attend a cram school [private exam tuition] and go to a private high school and university in the future. When we consider education costs, we think, 'We can't afford it for two children.' (A 36-year-old woman living in Fukuoka; ['Fōramu: Tanomuyo,' 2020])

The next statement from a mother shows how difficult it is for women who have small children to get a full-time job in Japan:

I am a non-regular university employee [who does not have maternity benefits]. It is difficult for me to have a second child. If I did have another child, I would have to give up my full-time job for a while. My first pregnancy ended in a premature birth, so I wouldn't be able to work if I get pregnant. We live in a very strange world - I have to choose between a job or a child. (A woman in her 30s living in Tokyo; ['Fōramu: Tanomuyo,' 2020])

The following statement shows that the woman feels guilty towards society and the nation because she chose not to have children at all:

When I hear the words 'declining birth rate,' I feel guilty. I feel like I haven't fulfilled my ultimate responsibility as a human. Naturally, I intended to give birth when I learned that I am pregnant. But at the time of the Lehman shock, there were cases where female colleagues on maternity leave could not return to work. I found it difficult to think positively about having a child. In addition, I didn't want to be bound by the stereotype that 'mothers should be like this.' (A woman in her 40s; [Takahashi, 2018])

On the other hand, the following statement from a father indicates discomfort in choosing the home over work after becoming a parent.

I was busy with work and I often felt guilty when I left work to go home. And I've become more and more frustrated with spending time with my family. Deep down in my heart, I felt that it was natural for me to have a work-oriented life even though I had children. On the other hand, I questioned why my wife didn't reduce her work responsibilities in order to take care of our child, and I was dissatisfied with her. (A man in his 30s; [Takahashi, 2019])

This comment highlights men's role in the fertility decline. Japan has generous paternity leave packages, with one year of paid parental leave available for fathers (with average income, fathers can earn roughly $60 \%$ of their wages during a year-long leave), but today only about $6 \%$ fathers in the private sector take advantage of this benefit. This shows why there was 
so much attention surrounding the decision by the 38-year-old Japanese environment minister, Shinjiro Koizumi, to take two weeks off to care for his newborn baby in 2020. The director of the Research Institute for Women and Careers at Japan Women's University, Machiko Osawa (as cited in Pinsker, 2020), explained the reason for Japanese men's disinterest in paternity leave: 'Taking paternity leave is more likely to reduce promotion possibilities in the future.' This means that to take time off work to care for one's own children is not in line with Japanese cultural norms for manhood.

\section{Psychological pressure on women to procreate}

Whereas Japanese men are publicly given credit for staying home with their children, Japanese women are publicly encouraged to have children and also blamed for not having given birth. According to the Japanese National Fertility Survey conducted in $2015,85.7 \%$ of men and $89.3 \%$ of women between the ages of 18 and 34 who have never been married desire to be married in the future. Moreover, $91.5 \%$ of men and $93.1 \%$ of women from this group desire to have one or more children in the future (National Institute of Population and Social Security Research, 2017). In Japan, women without children often experience social pressure to procreate. Some politicians have made statements criticising women without children for being selfish. In 2003, former Prime Minister Yoshiro Mori (as cited in Hays, 2014) stated,

The government takes care of women who have given birth to a lot of children as a way to thank them for their hard work. (...) It is wrong for women who haven't had a single child to ask for taxpayer money when they get old, after having enjoyed their freedom.

On a similar note, Japan's Deputy Prime Minister Taro Aso (as cited in Jozuka \& Ogura, 2019) stated in 2018, 'There are lots of strange people who blame the elderly for the population crisis, but they are wrong. The problem is with those who haven't given birth.' In 2019, the ex-minister addressed the problem of the nation's shrinking population and encouraged women to 'give birth to at least three children.' These comments outraged many people in Japan, especially feminists; however, there are quite a few people who unconsciously speak heartless words to childless women and couples. According to the survey conducted by Meiji Yasuda Research Institute in 2018, nearly $70 \%$ of married women and $30 \%$ of married men in their late 30 s to early 40 s have experienced harassment due to childlessness. The survey 
result also shows that many childless people feel uncomfortable to live in Japan.

\section{Norway: Between national welfare crisis, patriotism and global climate crisis}

In contrast to Japan, Norway has a comprehensive welfare state which includes a range of generous family policies including state-provisions for pregnancy, birth, extensive schemes for parental leave (including a parental leave designated to fathers), and publicly funded kindergartens and afterschool arrangements (Ellingsæter \& Pedersen, 2016). These policies, however, have not primarily been motivated by pro-natalist objectives but rather by gender equality ideologies and a concern for the general wellbeing of children and their families (Ravn et al., 2016). Moreover, Norwegians have relatively good access to part-time work, which means that parents who cannot or do not wish to work full-time can still earn income. Men's involvement in family life and care work is supported by the state, and this is an important part of the Norwegian model for gender equality, which has been described as dual carer/dual earner model (Ravn et al., 2016).

Despite these generous family policies, which have also been described as 'generous reproductive support' (Skrede, 2004), the average age of first childbirth has increased from under 24 in 1964 to nearly 29.8 in 2019 (Statistics Norway, 2020). Unlike Japan, Norway widely shares liberal social values and is more accepting of cohabiting couples and single people who have children. In 2014, unmarried mothers accounted for $44 \%$ of all births, and single mothers accounted for 13\% (Ellingsæter \& Pedersen, 2016). Still fewer and fewer women become mothers at young age.

\section{The call for more children}

In Norway, as in Japan, the declining fertility rates are overwhelmingly described as a serious problem for the country and its inhabitants' futures. This has been most obvious in recent years, when every new fertility-related measure has been declared 'the lowest one ever measured in the Norwegian context.' The most famous examples of this negative way of framing the declining fertility rate is to be found in Prime Minister Erna Solberg's New Year's speech at the beginning of 2019, where she explicitly asked the citizenry to have more babies:

We Norwegians are having fewer and fewer children. To maintain the population, each of us must have just over two children on average. Today the number is only 1.6. Then there will be relatively fewer young people who will have to bear an increasingly heavy welfare state on their shoulders. Norway needs more children! I do not think I need to explain 
how this is done. I will not make any orders either. Not everyone can have children or wants to have children. For various reasons. And more and more people are waiting longer to have children. Also for various reasons. But if you wait too long, it also becomes more difficult. An everincreasing number of children are now being created with the help of the health service [fertility treatments]. We must therefore ask: Is it too difficult to have children early? We must make good arrangements [for young people] to have children during their studies and early in their careers.

The message conveyed here is pretty clear: The fertility rate is not high enough for the nation of Norway - as we know it - to survive. In her speech, the Prime Minister was also explicit about her main worry, namely the sustainability of a comprehensive welfare state, which is dependent upon a relatively high number of workers and taxpayers. In this way, reproduction was made a question of labour resources and economy, rather than an issue of nationalist ideas about a particular Norwegian community or culture. The speech also provides some information about the problem's diagnosis, as the Prime Minister sees it, namely that the Norwegian population waits too long to have children. She also suggested a possible medicine in the form of political arrangements that will stimulate the population to start their reproductive career earlier in life.

Along a similar vein, other politicians as well as experts and representatives of various organisations have - both before and after this famous speech - expressed worries about the declining fertility rates. This has led to various measures being proposed to solve the problem. The list of suggestions includes increased child benefits, longer paternity leaves and various kinds of bonus for child number three, four and five (Kristensen, 2020). Every now and then, more liberal regulations of assisted reproduction technologies and more state support for using these technologies are also mentioned as relevant measures for increasing the national fertility rate, but only as an addition to the main solution of equal opportunities for parenthood (Stuvøy et al., 2021). However, the overarching question posed in the discussion is, What kind of welfare arrangements can be introduced and/or increased to motivate Norwegian women and men to have more children? The idea that welfare arrangements is an effective measurement is taken for granted; the question is only what exactly should be increased and by how much.

This idea that the state should try to enhance the national fertility rate by introducing various incentives and welfare arrangements represents a new direction in the Norwegian family policy, which up to this point had been presented as gender equality measures rather than pro-natalism. Thus, it is somewhat controversial. This controversy became particularly evident after Prime Minister Solberg's above-quoted speech in 2019, which was met with a lot of attention, including numerous media debates involving politicians, 
experts and lay people. Some debaters took issue with the Prime Minister's position as interfering in people's private lives and trying to put pressure on the younger generation, and in particular on young women. For example, Espen Gamlund (2019), a philosophy professor at the University of Bergen, wrote an opinion piece in a national newspaper with the headline, 'Nine reasons to be sceptical of the Prime Minister's call for more children.' He objected to the Prime Minister interfering in something which 'for the individual is so life-changing and irreversible,' noting that this way of talking about reproduction is 'reducing women into birth machines.' Similarly, Anne Lise Ellingsæter (as cited in Martinčič, 2020), a professor in sociology at the University of Oslo and expert in family policies and fertility rates, expressed it like this:

One can take one step back and ask what role the state should have when it comes to people's reproductive decisions. In my opinion, the Prime Minister's New Year's speech exemplifies that the state is entering people's private sphere when they are asking them to have more children.

\section{Stratifying statements about who should reproduce or not}

Whereas welfare arrangements and family policies are highly pertinent in the political debates about declining fertility rates in Norway, immigration is a more silent issue - at least on the governmental level. In recent years, this silence has somehow been broken, as various debaters have in different fora challenged the strict national focus on fertility rates. For example, the abovementioned Prof. Gamlund (2019) suggested increased international adoption as one alternative to increase the number of children per woman rather that enhancing the birth rate. Others have criticised the government for being double-minded by simultaneously fronting a restrictive immigration policy - which every year rejects the asylum applications of hundreds of children, even those living in very difficult situations in refugee camps - and calling on the nation 'to maintain the population,' as Solberg formulated it. This is how a representative for the Green Party in Norway, Farid Shariati (as cited in Skårderud, 2018), expressed himself to the newspaper Klassekampen when being asked about the prime minister's speech:

One can ask what kind of human view the government has, when they are so concerned with getting women to have more children rather than accepting more immigrants. (...) A better policy, if you want to increase Norway's population, is to be more open to the outside world. We can welcome new people and recognise that they are the most valuable resource available. (...) Norway spends a lot of money that contributes to the flattening of world population growth. 
That's a good thing. But it sends a rather special signal by simultaneously closing the borders for immigration and saying 'there must be more of us.'

But there are also voices sceptical towards these alternative strategies. This reveals that the main concern is not only about numbers, but also the future of the nation and who can and should be birthing the nation - to paraphrase Rodha Ann Kanaaneh (2002). An example showing how this notion can be formulated is to be found in a public statement delivered by Per Willy Amundsen, a representative of the Progress Party (Jensen, 2019): ${ }^{3}$

I think it is important that we have a sustainable population composition. The birth rate among ethnic Norwegians is declining. In line with the Prime Minister, I think it is important to do something about this. But, as I see it, the solution is not to have more immigrants. Quite the contrary we have to make sure that the ethnic Norwegian population is maintained.

Even though Amundsen is known for daring to say what 'common people' are thinking, this eugenics tendency is highly controversial and marginal in the Norwegian context. The fact that his statements have also received negative public reaction is a sign of their marginal status. Having said that, there are several examples of media texts presenting declining fertility numbers among immigrants as positive, which is somewhat paradoxical taking into consideration the call for more babies (Kristensen, 2009, 2020).

\section{Global over-population and national and/or individual responsibilities}

Another strand of discussion in regard to the Norwegian fertility rate is the pressure that the global population growth is putting on the planet, making it reasonable to reduce the number of children everywhere, including in Norway. This argument can typically be found in political claims fronted by the Green Party, experts on climate change and activists engaged in environmental organisations. Spokesperson for the Norwegian Green Party, Rasmus Hansson (as cited in Ekeberg, 2015), highlighted this point:

If they [the government] are actually planning to encourage people to have more children, they are really out of their minds. As I see it, such policies are so outdated, I can hardly believe it. The declining Norwegian fertility numbers are good news. We have to get rid of the idea that everything should increase, and rather start preparing for societies with fewer people. (...) We can't just sit here in rich Norway and claim that the population growth in Africa is the big problem. 
Another example of a statement which questions this idea of increased Norwegian fertility rates is expressed in a national newspaper by 28 -yearold Maja Sørheim (as cited in Salvesen, 2016), a woman who has taken individual moral pride in abstaining from motherhood for the good of the planet: 'Little indicates that the child would have a very good life on a heated and depleted planet. (...) Most important, however, is the fact that having children is equivalent to fuelling the fire further.'

So, even though the fertility rate in Norway is below replacement level, not everyone is sharing the political claim that this is a big problem that should be solved by stimulating the population to have more babies. Quite the contrary, the global population growth and the ways it relates to climate crisis is seen by many to be a much more important problem.

\section{Concluding discussion}

In this chapter we have explored the ways in which national fertility rates, and more specific declining fertility rates, are presented and discussed publicly in Japan and Norway. We have paid special attention to the kinds of explanations and measures that are put forward, and the similarities and differences in this regard that come to play when comparing the two countries. The fertility rates in both Japan and Norway are well below the replacement level, which means that the population will decrease if immigration is not sufficiently high. As our analysis has shown, this decline is seen as a serious problem among leading politicians. Former Prime Minister Abe called the declining birth rate a 'national crisis' at the Diet session in 2019. In the same year, the Norwegian Prime Minister communicated the same message to the Norwegian public by saying, 'Norway needs more children!' Both countries realise the need for countermeasures against the declining birth rate to prevent a future reduction of the labour force, a decline in economic growth and the collapse of the current pension system. However, the interpretations of the crisis and approaches to solving it are different in Japan and Norway. The Japanese government holds an implicit pro-natalist position. Many forms of fertility-related initiatives have been introduced expressly as population policies since the 1990s. The national government as well as the local governments devised various measures, such as monetary assistance in the form of child allowances paid directly to parents, promotion of parental leave, subsidies for childcare services and financial and psychological support for infertile couples. The governments have acted on the belief that the main causes of the declining birth rate are women's delayed marriage and late-in-life pregnancy. However, as this chapter has demonstrated, young people, especially women, expect certain financial and lifestyle difficulties in raising children. In recent years, the Japanese government regards women as an important source of labour and has encouraged them to participate in paid work to make up for labour 
shortage in the society with declining birth rate and ageing populations. However, there is still a strong tendency to regard unpaid work such as child-rearing and housework as women's role in the society. As we introduced in this chapter, Japan has generous paternity leave packages, but today very few fathers take advantage of this benefit. They believe that prioritising housework and childcare over their careers by taking paternity leave is more likely to reduce promotion possibilities in the future.

In comparison to other European countries, women's participation in the labour market in Norway is high, as $83 \%$ of mothers with small children are employed. The extensive schemes for parental leave and publicly funded kindergartens have rendered it possible for women to have a paid job outside the house. The Norwegian government's strategies for increasing fertility are very different from those of the Japanese, as illustrated by the Prime Minister's call for making it easier for young people to have children. In addition, the Norwegian government also pays attention to men's reproductive behaviours and involvement in family life and care work.

On the other hand, in Japan, the rate of births outside of marriage is $2.2 \%$ (Organisation for Economic Cooperation and Development [OECD], 2019). Marriage and childbirth are difficult for the Japanese to consider separately; thus, accepting the idea that women become pregnant while in school and (likely) single is difficult. Instead, the Japanese government has adopted strategies for supporting infertile couples financially and psychologically in order to stop the declining birth rate. However, it has a risk of leading to prejudice against women without children, since a woman's value in society is more likely to be defined according to whether she can give birth. In fact, as we have shown, some politicians have made discriminatory statements against women without children.

Since Norway is already tolerant towards cohabiting unmarried couples, single people and same sex couples, the government provides the same family support to all. Although the Japanese government has given lip-service to the importance of gender equality and initiated some legislation, the rhetoric of many politicians shows that they still have conservative views about marriage, gender roles and childbirth. The Japanese government is also conservative about family formation. It is reluctant to accept diversity and premises its population policies on the traditional nuclear family of heterosexual parents with children. This position puts more burden on women than on men due to the stereotype that women are the main players in housework and childcare.

Immigration is also a factor in both countries. In Norway, immigrants are an important part of the labour force; however, some negative views remain concerning immigrants' fertility. If the national fertility rate continues to decline, immigration will be vital for avoiding a population decline. Even in Japan, society is becoming reliant on immigrant labour. In this regard, it is crucial to consider issues posed by a growing immigrant population within a host society experiencing a declining birth rate. 
A significant difference in the gender gap exists between Japan and Norway. In 2020, the Global Gender Gap Report showed that in the political arena, Norway ranked 3rd out of 156 countries, whereas Japan ranked 120th, and 147th in the political arena. The difference in the gender gap exerts a great impact on the birth policies of the two nations. The fact that Norway's population policies focus on gender equality is a by-product of women's greater participation in working life and political life. In Japan, however, women have little voice in formal politics at the national level, and the employment rate of women is too low. The policies which support working mothers and young couples are not effective enough due to the small number of female politicians and female policy makers, causing the burden on women to increase. In addition, Norway has a better social support system than Japan for all parents and has tried to eliminate genderbased injustice concerning childcare. Seemingly, Norwegian women find work-life balance much easier to achieve than Japanese women do.

Returning to Yuval-Davis' (1997) discourses on fertility and population control, our study finds that the 'people as power discourse' is most prominent in both contexts. It is made particularly explicit through the national leaders' calls for more children. The Malthusian discourse, however, does not appear as relevant for the national context, which is not surprising as the fertility level is extremely low. In Norway, however, the Malthusian discourse does appear in some public discourse, namely when addressing the link of population growth to the climate crisis. The eugenics discourse also features at times, such as when immigrants' fertility rates are discussed. However, for the most part, these perspectives appear as a marginal discourse in Norway compared to the 'people as power' approach.

In any case, the fertility rate is declining not only in Japan but also in Norway. Our analysis indicates that gender equality policies alone are insufficient to mitigate the declining birth rate. Thus, we argue that there is a need for more in-depth research on how young people are experiencing parenthood, and on the roles parenting and family life, including childcare, have in their imaginations of a good and desirable life.

\section{Notes}

1 The term fertility rate refers to the term total fertility rate that represents the number of children that would be born to a woman if she were to live to the end of her childbearing years and bear children in accordance with age-specific fertility rate of the specific year (The Economist Intelligence Unit, 2018).

2 The term replacement level fertility is the fertility rate at which a population is able to replace itself from one generation to the next (Craig, 1994). The Population Division of the United Nations has long used a total fertility of 2.1 children per woman as equivalent to replacement level.

3 A populist party on the far right. 


\section{References}

Abe, S. (2019, 4 October). Policy speech by Prime Minister Shinzo Abe to the 200th [Speech transcription; provisional translation]. Prime Minister of Japan and His Cabinet. https://japan.kantei.go.jp/98_abe/statement/201910/_00003.html

Arnoldi, J. (2005). Medieanalyse og Niklas Luhmanns systemteori [Media analysis and Niklas Luhman's system theories]. In M. Järvinen, \& N. Mik-Meyer (Eds.), Kvalitative metoder i et interaksjonistisk perspektiv [Qualitative methods in an interactionist perspective]. Hans Reizels Forlag.

Atoh, M. (1994). The recent fertility decline in Japan: Change in women's role and status and their policy implications. The population and society of postwar Japan based on half century of surveys on family planning. The Mainichi Newspapers.

Cabinet Office. (2018). Sentaku suru Mirai, Jinkō suikei kara mieru miraizō [The choice for the future: Future image seen from the estimation of population]. [Report]. https:// www5.cao.go.jp/keizai-shimon/kaigi/special/future/sentaku/s2_3.html

Castro-Vázquez, G. (2017). Intimacy and reproduction in contemporary Japan. Routledge.

Clarke, A., \& Haraway, D. (2019). Making Kin not Population. Prickly Paradigm Press.

Craig, J. (1994). Replacement level fertility and future population growth. Population Trends-London, 78, 20-22.

Ekeberg, E. (2015, 17 July). Et miljøproblem [An Environmental Problem]. Klassekampen.

Ellingsæter, A.L., \& Pedersen, E. (2016). Institutional trust: Family policy and fertility in Norway. Social Politics, 1(23), 119-141.

Fōramu: Tanomuyo, Suga Naikaku 2: Kosodate [Forum: Please, Suga Cabinet Part 2: Child Rearing]. (2020, 4 October). Asahi Digital. https://digital.asahi.com/ articles/DA3S14645960.html

Gamlund, E. (2019, 7 January). Ni grunner til skepsis mot statsministerens ønske om flere barn [Nine reasons to be sceptical of the Prime Minister's call for more children]. Aftenposten. https://www.aftenposten.no/meninger/kronikk/i/RxMy9x/ni-grunner-tilskepsis-mot-statsministerens-oenske-om-flere-barn-espe

Hartmann, B. (1995). Reproductive rights and wrongs. The global politics of population controls. South End Press.

Hays, J. (2014). Women in Japan: History, character, customs, advancements and violence. http://factsanddetails.com/japan/cat18/sub118/item627.html

Hoiku no oshigoto report. (2019, 21 March). (2019nen saishinban) Shitte okitai taikijido mondai no genjo to kadai - Genin to Taisaku [(2019 latest version) Current status of issues on waiting list for nursery schools - Causes and countermeasures]. [Report]. https://hoiku-shigoto.com/report/archives/16315/

'Itten Toppa' Funin chiryō josei mo ['One point break through' infertility treatment costs subsidy]. (2020, 24 September). Asahi Digital. https://digital.asahi.com/ articles/DA3S14633037.html

Jozuka, E., \& Ogura, J. (2019, 5 February). Japan's deputy prime minister blames women 'not giving birth' for declining population. CNN. https://edition.cnn.com/201 9/02/04/asia/japan-taro-aso-women-demographics-intl/index.html

Jensen, I. (2019, 10 January). Vil kutte i barnetrygden for at innvandrere skal få forre barn [Want to shorten child benefits to make immigrants have fewer children]. 2Nyheter. https://www.tv2.no/a/10335046/ 
Kanaaneh, R.A. (2002). Birthing the nation: Strategies of Palestinian women in Israel. University of California Press.

Kristensen, G.K. (2020). Offentlige samtaler om fruktbarhet i dagens Norge. Mellom nasjonal velferdsstatskrise og global klimakrise [Public discourses about fertility in contemporary Norway. Between national welfare state crisis and global climate crisis]. Tidsskrift for kjønnsforskning, 44(2). https://www.idunn.no/tfk/2020/02/offentlige_ samtaler_om_fruktbarhet_i_dagens_norge

Kristensen, G.K. (2009). Tobarnskull møter stua full? Innvandreres fødselstall i norsk offentlig diskurs [Two child families meeting families with many children? Immigrants' fertility rate in Norwegian public discourse]. Tidsskrift for kjønnsforskning, 33(4) https://www.idunn.no/tfk/2009/04/art01

Lezott, C. (2020, 29 March). Problems single mothers face in Japan. Zenbird. https://zenbird.media/problems-single-mothers-face-in-japan/

Meiji Yasuda Research Institute. (2018). 25-44 sai no shussann/kosodate ni kansuru chōsa (Survey on childbirth and childcare for Japanese men and women aged 25 to 44 years). [Report]. https://www.myri.co.jp/research/report/pdf/myilw_report_2018_ 03.pdf

The Ministry of Health, Labour and Welfare. (2020). Reiwa gannen (2019) Jinkō doutai toukei (kakutei sū) no gaikyō. [Overview of Vital Statistics 2019]. [Report]. https:// www.mhlw.go.jp/toukei/saikin/hw/jinkou/kakutei19/dl/15_all.pdf

Martinčič, J. (2020, 11 July). Det er et økt press på kvinner om å føde flere barn, ifølge forsker [According to researcher there is an increasing pressure on people to have more children]. Forskning.no. https://forskning.no/barn-og-ungdom-demografi-kilden/deter-et-okt-press-pa-kvinner-om-a-fode-flere-barn-ifolge-forsker/1711055

National Institute of Population and Social Security Research. (2017). Marriage and Childbirth in Japan today: The fifteenth Japanese National Fertility Survey in 2015 - Marriage process and fertility of married couples attitudes toward marriage and family among Japanese singles: Summary of the survey results on married couples/ singles. [Report]. http://www.ipss.go.jp/ps-doukou/e/doukou15/ Nfs15R_summary_eng.pdf

'Number of newborns in Japan fell to record low while population dropped faster than ever in 2018.' (2019, 7 June). The Japan Times. https://www.japantimes. co.jp/news/2019/06/07/national/number-newborns-japan-fell-low-918397-2018government-survey/

Organisation for Economic Cooperation and Development. (2019). SF2.4 Share of births outside of marriage. Family Database in the Asian-Pacific Region. http:// www.oecdkorea.org/resource/download/2019/eng/SF_2_4_Share_births_ outside_marriage.pdf

Parents protest over lack of child care facilities after Abe's weak response to blog post. (2016, $7 \mathrm{March}$ ). The Mainichi. https://mainichi.jp/english/articles/201603 $07 / \mathrm{p} 2 \mathrm{a} / 00 \mathrm{~m} / 0 \mathrm{na} / 011000 \mathrm{c}$

Pinsker, J. (2020, 24 January). Why Icelandic dads take parental leave and Japanese dads don't. The Atlantic. https://www.theatlantic.com/family/archive/2020/01/ japan-paternity-leave-koizumi/605344/

Ravn, M.N. (2005). A matter of free choice? Some structural and cultural influences on the decision to have or not to have children in Norway. In C.B. Douglass (Ed.), Barren states: The population 'implosion' in Europe. Berg Publishers. 
Ravn, M.N., Kristensen, G.K., \& Sørensen, S.Ø. (Eds.). (2016). Reproduksjon, kjønn og likestilling $i$ dagens Norge [Reproduction, gender and gender equality in contemporary Norway]. Fagbokforlaget.

Salvesen, I. (2016, 30 January). Velger klima foran baby [Put the climate before babies]. Dagens Næringsliv.

Skårderud, J. (2018, 7 December). Skal lage barn [Will make children]. Klassekampen. https://klassekampen.no/utgave/2018-12-07/skal-lage-barn

Skrede, K., Ellings'ter, A.L., \& Leira, A. (2004). Familiepolitikkens grense - ved 'likestilling light'? (At the border of family policies - 'equality light'? In: Ellingsæte, A. L. \& Leira, A. Velferdsstatens utfordringer og dilemmaer (The challenges and dilemmaes of the welfare state). Gyldendal akademisk.

Solberg. E. (2019). Statsministerens nyttårstale 2019 [The Prime Minister's annual speech]. Regjeringen.no. https://www.regjeringen.no/no/aktuelt/statsministerensnyttarstale-2019/id2623249/

Statistics Bureau of Japan. (2019). Tōkei kara mita wagakuni no kōreisha, 'Keirō no hi ni chinande [Elderly people in Japan from the viewpoint of statistics: Special edition of Respect-for-Senior-Citizens Day]. Statistics Topic (No. 121). [Report]. https://www.stat.go.jp/data/topics/topi1211.html

Statistics Norway. (2020, 11 March). Births. [Report]. https://www.ssb.no/en/fodte Statista. (2021a). Rate ofpopulation growth in Norway from 2010 to 2020. [Report]. https:/www.statista.com/statistics/587348/population-growth-in-norway/

Statista. (2021b). Japan: Population growth from 2009 to 2019. [Report]. https:// www.statista.com/statistics/270074/population-growth-in-japan/

Stuvøy, I., Kirpichenko, M., Kristensen, G.K., \& Lie, M. (2021). Bioteknologiske fremtider. Refleksjoner over endringer $i$ Bioteknologiloven fra et kjønnsforskningsperspektiv [Biotechnological futures. Reflections over changes in the Biotechnological law from a gender studies perspective]. Tidsskrift for kjønnsforskning.

Takahashi, M. (2018, 30 August). Kazokutte? 'Umu' hen 6: Hoshiku nakatta wakejanai [What is family? 'Giving birth' Series 6: It is not that they don't want to have a child]. Asahi Digital. https://digital.asahi.com/articles/DA3S136564 82.html

Takahashi, K. (2019, 13 July). Chichioya no moyamoya, 'kisha no kokuhaku.' Shigoto to katei no itabasami, kurushii [Father is gloomy, reporter's confession: It is painful to get caught between work and home]. Asahi Digital. https:// digital.asahi.com/articles/DA3S14094674.html

The Economist Intelligence Unit. (2018). Fertile ground: How can Japan raise its fertility rate? The report by The Economist Intelligence Unit. The Economist Intelligence Unit. [Report]. http://www.eiu.com/graphics/marketing/pdf/Fertilityin-Japan-EIU.pdf

Tsuya, N.O. (2017). Low fertility in Japan: No end in sight. Asia Pacific Issues, 131. https://www.eastwestcenter.org/publications/low-fertility-in-japan \%E2\% 80\%94 no-end-in-sight

United Nations. (2019). Total population. World Population Prospect 2019. [Report]. https://population.un.org/wpp/Download/Probabilistic/Population/ Yuval-Davis, N. (1997). Gender \& nation. Sage Publications. 


\section{Assisted reproduction with donated eggs and sperm: A comparison of regulations on assisted reproduction in Norway and Japan}

\section{Merete Lie and Yukari Semba}

\section{Assisted reproduction in Norway and Japan}

Assisted reproductive technologies (ARTs) spread globally after the first birth by in vitro fertilisation (IVF) took place in the UK in 1978. IVF is a process of fertilisation, whereby an egg is combined with sperm outside the body, in vitro. The first IVF baby was called a 'test-tube baby' (Van Dyck, 1995) and the term from their initial introduction was 'artificial reproduction.' Opponents warned against ARTs on the grounds that reproduction constituted the very basis of humanity and that scientists were 'playing God.' Moreover, ARTs go to the core of gender distinction as it is understood as based in sexual reproduction. Despite these controversies, ARTs were rapidly and eagerly adopted. This led to advances in reproductive science and practice which, in turn, resulted in new methods and more efficient practices. As the very same reproductive technologies rapidly spread globally, controversy generally followed. However, the arguments proposed in the ensuing debates, especially the weight given to various arguments, differed across nations (e.g., Inhorn \& van Balen, 2002; Lie \& Lykke, 2017). By looking comparatively at the cases of Japan and Norway, we investigate the localised nature of the ART debate.

In this chapter, we will compare the regulations of ARTs in two nations that differ culturally and socially - both historically and in contemporary times. According to Jasanoff (2005), regulations governing emerging life sciences have been incorporated into national projects to proclaim the basic values of a nation. These may be as varied as being in the frontline of science and progress versus fronting strict regulations substantiated in cultural values or religion. When ARTs were introduced in the UK, for example, values prominent during the Thatcher era, such as the promotion of a new enterprise culture and the value of individual consumer choice, constituted the framework of the political debate (Franklin, 1997). In the US, however, as Becker (2000) pointed out, the conservative notion of family values was the moral authority underlying the debate. In Norway, the political debate was grounded in the pillars of the welfare state, the belief in 


\section{2}

technology and progress, and a widely shared value of gender equality (Spilker \& Lie, 2007). In Japan, Dr. Masakuni Suzuki, who successfully conducted the country's first IVF in 1983 at Tohoku University, argued that IVF technology would help many people suffering from infertility and ultimately help the country by enabling the procreation of new citizens (Yui, 2016).

To compare the responses to ARTs in Japan and Norway, the chapter poses two key questions. Firstly, what are the differences and similarities in the regulations of ARTs - that is, what is permitted and for whom? Secondly, how are the regulations justified, and what does such a justification say about the two countries' basic values and cultural differences in the late 20th and early 21st centuries? Public discourse and policy - that is, the debates and decisions on these matters - comprise our source material for discussing how meaning and morality are articulated in relation to gender and reproduction in the two countries.

\section{Theoretical perspectives}

This chapter frames our investigation of ARTs in Japan and Norway by focusing on a comparison of the regulations of gamete donation in the two countries. This is one of the many intriguing ART fields whereby one and the same technology functions differently across cultures. This has inspired Science, Technology and Society (STS) research on the social and cultural aspects of technologies and their technical development as well as crosscultural studies among anthropologists.

Regarding STS research, Jasanoff (2005) argues that cross-state comparisons often have the aim of determining best practices and policies by learning from other countries. According to Jasanoff, however, the problem here is twofold. One is that national policies are not independent of local cultural and social factors; inevitably, cultural differences trickle into policy making. Even when policymakers in different countries lean on similar data and scientific arguments, these may be interpreted differently or given different weight depending on the local context (Jasanoff, 2005, p. 17). Moreover, the same policies will not function in the same way in the environments in which they are introduced, and their effects will vary accordingly.

Research in medical anthropology underscores Jasanoff's position. Crosscultural studies in this field elaborate differences that reveal the inherently local and political nature of biomedicine and biotechnology (Adelson et al., 2013). Moreover, not only may health services and medical training differ among nations but also symptoms and diseases within populations. For instance, Lock (1993) examines women's experience of menopause and finds striking differences between Japan and the US. In the US, menopause is experienced as a major physical transition characterised by well-known symptoms such as hot flashes. In Japan, however, menopause is not regarded as a major life event but 
part of an ongoing process towards ageing; stiff shoulders are reported but seldom are hot flashes (Lock, 1993). Thus, the experience of bodily symptoms can hardly be discerned from a single society's expectations for health and illness. Similarly, national health services organised to care for the population build on such expectations.

Globalisation means that science and technologies, as well as people and cultural influences, are increasingly travelling across borders. Nevertheless, similar influences may meet a variety of responses (Inda \& Rosaldo, 2008). Therefore, anthropologists hold that comparisons should be locally embedded and not pretend to hold a disembodied 'gaze from nowhere' (Haraway, 1988). As the same phenomenon does not signify the same within different contexts, anthropologists argue against making crosscultural comparisons out of context and argue for making comparisons only when they are locally embedded (Gingrich \& Fox, 2002). Moreover, in anthropological studies comparison occurs also more implicitly as one inevitably will use one's own background as reference when investigating similar phenomena in other countries. Our advantage is that each author's point of departure is the knowledge of their own country.

The chapter focuses on the case of assisted reproduction with donated gametes (eggs and sperm). The data material consists of official government documents, official announcements, reports from professional groups and Parliamentary debates, and information from news media on political debates on this issue in Japan and Norway. Because of different developments in the two countries - such as legalisation versus guidelines and the relative power of the Parliamentary representatives versus professional organisations - the emphasis on the use of different types of data differs in the analyses of Japan and Norway. In the analyses, we identify instances of socially and culturally grounded reasoning that frame the pro-and-con arguments of gamete donation in the two countries. What arguments and by whom have passed as relevant and legitimate, and on what grounds did both countries shift from long-term restrictions to the recent permission of egg donation?

In the following, we will analyse this development over time in each country and study the debates and decision-making as processes of cultural production. As debates and policies vary, these sections will focus partly on the same issues and partly on different ones. This examination leads to our discussion of similarities and differences in ART regulations and arguments in the pro/con debates in the two countries.

\section{ART regulations in Japan}

\section{Sperm donation}

The history of ART in Japan dates back to the late 1940s. In 1948, Dr. Kakuichi Ando of the Medical School in Keio University, Tokyo, 


\section{4}

initiated donor insemination (DI) procedures at the request of a couple suffering from male infertility. The first DI baby was born in 1949 in Japan. Since then, more than between 10,000 and 15,000 DI offspring are estimated to have been born (Minami, 2016). Dr. Ando faced severe disapproval after news of the first DI baby became public. However, he defended his decision as necessary for helping a legally married infertile couple. In Japanese culture, the eldest son traditionally took on the mantle of head of household and was expected to perpetuate the family name. Thus, the eldest male progeny and his wife were expected to bear children regardless of circumstances (Castro-Vàzquez, 2017). This emphasis on paternal duty shaped DI in Japan as an important means of protecting the masculinity of infertile men, whether or not they were fathers in genetic terms. DI was also beneficial for women because the majority of people at the time ascribed the fault of infertility to the wife. Not only did this assumption devalue the childless wife, but it also threatened her marriage (Takeya, 2008). If a couple was unable to bear a child, then continuing the marriage became difficult for them. Hence, DI became acceptable due to public sympathy for infertile couples.

Thus, sperm donation has been practised since the 1940s, and the first commercial sperm bank in Japan was established in 1996. Subsequently, in 1997, Japan Society of Obstetrics and Gynecology (JSOG) established its first guidelines pertaining to DI, which stipulated that the technique should only be offered to legally married couples, that the wife and husband should tender informed consent and that the commercial provision of the donated sperm to infertile couples should be prohibited. Since 2018, however, fear of identity disclosure has led to a decrease in the number of anonymous sperm donors. One hospital cautioned potential sperm donors about the possibilities of identity disclosure in the informed consent form. The form stated that their anonymity might be in jeopardy if a donor offspring initiated legal action at any time in the future to demand the disclosure of the donor's identity and personal information (Osaki, 2020). This decrease has meant that people in Japan with infertility who are seeking to conceive through donated sperm are likely to go abroad or turn to online sperm donation (Kobayashi et al., 2020).

\section{Egg donation}

The first IVF baby in Japan was born in 1983. ARTs accounted for 5.8\%, or 1 in 16.7, of all babies born in Japan in 2017 (Katagiri, 2020). Despite the substantial application of ARTs, no laws or legal regulations regarding ARTs existed until recently in Japan. Third-party reproduction has been governed by the guidelines established by the JSOG. Under JSOG guidelines, clinics could only utilise IVF with legally married couples. They could not assist women with becoming egg donors for other women. However, these guidelines are not legally binding, meaning that clinicians can 
continue their medical careers even if they violate them. The first case of IVF using donated eggs in Japan was publicly disclosed in 1998. Dr. Nezu Yahiro had performed IVF using eggs donated by a wife's sister, leading to him later being temporarily expelled from JSOG for violating its guidelines (Kinjō, 2012). There are also numerous instances of couples traveling overseas to seek donated eggs because they could not get donated egg in Japan.

In response to the first domestic egg donation case and the rise of Japanese couples seeking donated eggs abroad, the former Ministry of Health and Welfare (currently the Ministry of Health, Labour and Welfare) established the ART Committee in June 2001 to discuss the drafting of a new bill on third-party reproduction (Tsuge, 2005). In 2003, the ART Committee concluded that reproductive medicine using donated gametes should be permitted, that treatments using gametes of siblings or other relatives should be prohibited and that the offspring should be accorded the right to acquire donor information. However, no law incorporating the Committee's conclusions had been enacted at this time.

The Japanese Institution for Standardizing Assisted Reproductive Technology (JISART), established in 2003, is an organisation that regulates the standards and practices of ART clinics with the aim of achievement of high standards of practice of infertility management. According to its bylaws, JISART aims to improve the quality of patient care through the implementation of a quality management system in Japan. Since 2007, clinics registered as members of JISART perform IVF using donated eggs after acquiring requisite approvals from the JISART's ethics committees (JISART, 2021).

The Oocyte Donation Network (OD-Net) was established in Japan in August 2012 with the objective of helping women with congenitally reduced ovarian functions (e.g., Turner syndrome) as well as prematurely menopausal women. OD-Net began to recruit voluntary egg donors and launched Japan's first egg bank in 2013. OD-Net's stipulations for donor candidates requires that the women are under 35 years of age, have previously given birth, are a good match for recipients in medical terms, have consent from their husbands to register as donors, would provide their eggs free of charge, and are willing to disclose their identities if the donorconceived child requires it upon reaching the age of 15. OD-Net reported that the first child conceived by using donated eggs from an anonymous volunteer egg donor was born in 2017. However, it is still hard to find egg donors in Japan. So, certain countries in south and southeast Asia, such as India, Thailand, Vietnam, Laos, Nepal, and Cambodia, were destinations for Japanese fertility tourists seeking donated eggs. Most of these nations have recently banned the provision of eggs to foreign clients due to problems related to donor conception. Therefore, Some Japanese couples travel to Eastern Europe, Russia and the US, for this purpose ('Score of life,' 2014). 


\section{Legalisation of gamete donation}

Male infertility has been regarded as a more serious crisis than women's infertility because the husband's bloodline has long been viewed as more important in Japan. Many infertile men have confessed that their inability to father children made them feel that they had no value because they did not live up to the male gender role (Kurahashi, 2017). Thus, DI was introduced to simultaneously alleviate male anxiety and mask male infertility. Nevertheless, women without children still face prejudice and discrimination, bearing the stigma of assumed infertility.

A 2014 survey of public attitudes towards third-party reproduction in Japan revealed a notable division: $36.2 \%$ of respondents considered gamete or embryo donations as socially acceptable, whereas $26.6 \%$ found them unacceptable (Yamamoto et al., 2018). Although the demand for egg donation is expected to increase in Japan as women marry later in life and incidences of age-related infertility increase, some barriers remain in place such as egg donors may incur risks such as ovarian hyperstimulation syndrome or damage to ovaries caused by egg retrieval for another woman. In $2018,99 \%$ of hospitals and clinics performing IVF in Japan refrained from facilitating egg donations because of JSOG's guidelines (Shirai, 2019).

On 4 December 2020, the Japanese Diet (Parliament) passed Seishoku Iryō Minpō Tokureihō (Reiwa 2 nen hōritsu dai 76 gō [Reproductive Medicine Civil Code Special Law (2020 Law No. 76)]), which recognised the legal parenthood of married couples who bore children through donated eggs and sperm. Sperm donor shortage had become a serious issue since the beginning of the 21 st century. It was thought that fewer men were willing to donate their sperm once they learned of the increasing legal rights of children globally to contact their biological parents (Robertson, 2018). Thus, the new ART law defines the parentage of children born through ARTs using donated gametes, and, in March 2021, both sperm donation and egg donation became legal in Japan under the special ART law. The main objective of the law is to stabilise the legal status of children born through third-party reproduction. The law stipulates that children born through egg or sperm donation will legally be the children of the birth mother and the mother's husband who agreed to the use of the donated eggs and sperm. However, the law does not address the use of donated gametes by same-sex women couples and single women, only that by opposite-sex couples. This is a strong example of lawmakers' attachment to the traditional view of the family as composed of heterosexual parents and their children. Meanwhile, additional clauses in Reproductive Medicine Civil Code Special Law in 2020 state that 'necessary legal measures will be taken within a target of roughly two years' regarding the right of the donorconceived children to know their donors. Although donor anonymity is an important issue in many countries, it cannot be preserved in any case, given the current availability of genetic testing and tracing (Harper et al., 2016). 
Moreover, the law does not cover other pressing issues, such as commercial gamete donation and surrogacy. The 2021 law nonetheless does reflect anxiety over Japan's aging population and declining birth rate, and it is congruent with the national objective of promoting childbirth (Wernick, 2020).

\section{ART regulations in Norway}

Norway was an early initiator of legal regulations governing ARTs, having implemented them as early as 1987 . Until recently, its legal regulations have been among the strictest in the world (Bleikli et al., 2004; Engeli \& Allison, 2017). However, a radical turn occurred in 2020 when the Parliament voted in favour of egg donation, access to fertility treatments for single women and egg freezing without medical reasons. Whereas previously a need for caution had been the winning argument for change, now the main argument was that a modern society should make use of technologies once they are available and follow up on those under development.

This section will cover the development of ART regulations in Norway. Norway has a comprehensive public health service offering medical examination and three free IVF trials, initially for only heterosexual couples but later also offered to same-sex women couples and single women. Private clinics provide fertility treatments but require clients to pay for the treatments; the related drugs are subsidised by the state.

As in Japan, debate over ART in Norway goes back to the 1950s. In the early 1950s, a debate on DI surfaced after the appointment of a committee tasked with evaluating the practice and the legal status of the resulting offspring. The report resulted in a sharp debate in which opponents of the practice argued that donor sperm morally undermined the very essence of marriage by allowing a third person into the parental relationship (Melhuus, 2012). ${ }^{1}$ Nevertheless, no ban on insemination with donor sperm was introduced.

Heated debates started again after the birth of the first IVF babies, in England in 1978 and in Norway in 1984. Three years later, in 1987, the first legal regulation, entitled Law on Artificial Conception, was introduced in Norway. In 1994, new ART regulations were included in the more comprehensive Law on Medical Use of Biotechnology. Although the 1987 law permitted sperm donation, it prohibited egg donation. In 1994, however, an amendment to the law allowed for egg donation for those with certain medical conditions.

ARTs remained politically controversial. The term used for the techniques was artificial fertilisation, and, in media debates, practitioners were accused of tampering with nature. During the 1990s, to avoid stigmatising parents and their IVF children, the official term was set as 'assisted fertilisation.' In 2002, the government headed by the right-wing Christian Democratic Party - the political party most engaged in these issues brought about a Parliamentary debate on revision of the 1994 law. Access 
to egg donation, the most controversial issue at the time, had many supporters but not enough to win the majority. The vote in the Parliament resulted in an even stricter law. Egg donation remained prohibited, supported by the argument that there should be no doubt as to the identity of the child's mother. Moreover, it was voted in favour of upheaval of anonymity of sperm donors with reference to the child's right to know its origin.

In the 2002 debate, the Labour Party framed the issue of egg donation as a question of gender equality, arguing that if sperm donation is legal, then egg donation should likewise be allowed. Since gender equality is highly valued in Norway, the ban on egg donation was posed as a denial of gender equality. A representative from the conservative political party Høyre (The Right) countered this supposition by stating a limit to gender equality based on biological difference: 'Not everything can, or should, be made equal' (Spilker \& Lie, 2007, p. 335). Norway follows the traditional Roman law, Mater semper certa est (motherhood is always certain); thus, a mother is legally defined as the person who gave birth to a child. However, legal fatherhood is defined in social terms as the man who is married to the woman who gives birth (Pater est quem nuptiae demonstrant). In the debate, gender emerges as highly relevant in the bioethical debate with gametes as a form of stand-in for women and men and their respective sexual behaviours. Politicians argued that whereas eggs remain in a woman's body, sperm had always 'gone astray,' pointing to men's extramarital sexual behaviour. However, egg cells should remain with the birth mother, and it was essential to avoid raising doubts about the identity of the mother.

From 2003 to 2020, the Law on Medical Use of Biotechnology remained in effect with two exceptions. In 2007, same-sex couples received access to treatment. This was a consequence of changing the law of marriage by granting same-sex couples equal legal rights to heterosexual couples. Later, access was granted to couples where one person has a heritable venereal disease, such as HIV. Thus, no longer was a couple's infertility the only qualification for ART. The law continued to gradually loosen until a revision in 2020 instantly changed the Norwegian Biotechnology Act from one of the strictest in the world to a relatively liberal one. Egg donation was legalised along with fertility treatment for single women. The law also permitted egg freezing without medical reasons and access to early ultrasound examination ${ }^{2}$ and NIPT (non-invasive pre-natal) testing for all pregnant women. Nevertheless, certain restrictions were added, such as an age limit of 46 years for a woman to gain access to ARTs. Egg donation was limited to couples where one parent would have a genetic relation to the offspring. Parents were obliged to tell children that they were conceived via a donor, and the age for children to ask for information about donors was lowered from 18 years to 15 years.

Returning to public discourse on ARTs, we find that Parliamentary debate in 2020 emphasised arguments that affirmed Norway's status as an 
up-to-date society and a gender equal one. Firstly, lawmakers argued in favour of liberalising the law on the grounds that the technology had developed and matured. To be a modern society, they argued, Norway should permit and use these technologies. Secondly, they contended that these changes meant acknowledging women's fertility rights. Many of the speakers supported the argument that Norway needed a modern Biotechnology Act to uphold the value of giving the population access to modern medical treatments. Previously, the principal concern of the Norwegian Biotechnology Act has been precautionary, employing a 'better safe than sorry' approach so long as the consequences remain unknown (Melhuus, 2012). However, the most persuasive arguments in 2020 was the need to update and remain in the frontline of global technological developments. Thus, the Parliament voted in favour of a suggestion that the law should be continually reviewed and updated to adapt to rapid developments in biotechnology.

There was a debate on restrictions regarding the use of surrogacy abroad among Norwegian citizens, but this suggestion was not approved. The prohibition of surrogacy, however, was retained with a clear majority. Moreover, the government was urged to work in international fora 'against the abuse of women in the international surrogacy industry. ${ }^{3}$

The importance of notions of gender equality differed in 2002 and 2020. In 2002, for example, support for egg donation as a matter of gender equality failed to win the majority. At the time, the vote against egg donation was based on a partially forthright and partially implicit assumption about the priority of motherhood, which worked against equalising egg and sperm donation. The 2020 debate, however, did not frame equality as a matter of gender but as a question of access to treatments within the public health service. This position argued that all women regardless of income and location must be provided access to such specialised health services. The argument of equal access also included the aim of putting an end to the so-called fertility travel abroad. Access to available fertility treatments and tests were presented as women's rights, whereas men were seldom mentioned in the debate. Only a few representatives spoke against fertility treatment for single women by arguing that children need fathers. This lack of debate about fatherhood and support for single motherhood was slightly surprising given the long campaign to acknowledge the equal importance of fatherhood and motherhood as part of gender equality policies in Norway. Legally and culturally, Norway has a bilateral kinship system, acknowledging genetic as well as economic and social inheritance from both sides.

The 2020 debate in Norway's Parliament illuminated how ART regulations are considered ethical and political questions, guided by the perceptions and politics of gender. During the debates, there was hardly any reference to medical expertise or consideration of advice from the officially appointed Biotechnology Advisory Board. ${ }^{4}$ Rather, the debate mainly centred on differing values and morals among the lawmakers. Before the 
vote, a major newspaper in Norway conducted a survey on the question of egg donation and found that $57 \%$ of respondents were in favour of legalising the practice. ${ }^{5}$ Furthermore, young people were more positive about egg donation than older people were. Among the adherents of different political parties, those voting for the left were most positive; only those voting for the Christian Democratic Party had a clear majority against egg donation. In 2002, the conservative party Høyre had argued against egg donation based on the primacy of motherhood and the importance of never questioning the identity of the mother. In 2020, however, they argued in favour of egg donation when the arguments had shifted to individual rights for access to available treatments. The recent legal permissiveness may also be due to the rapid decrease in Norway's fertility rate and an appeal from the conservative Prime Minister for the nation to making more babies (cf. Chapter 11 in this book).

\section{Egg and sperm across nations: Similarities and differences}

Human reproduction is closely associated with gender norms, sexuality, family patterns and kinship. Hence, cultural differences most visibly surface in these areas during the debates and regulations of ARTs.

In both Japan and Norway, a marked divide has existed between the legality of sperm donation versus the prohibition on egg donation. Although sperm donation has been practiced for a long time and included in the health services of both countries, IVF using donated eggs was prohibited in Norway and Japan until 2020 and 2021, respectively. In Norway, DI was controversial but publicly recognised when it became part of the national health service in 1972. In 2005, the donor anonymity clause was rescinded, based on the belief in a child's right to know its origin. In Japan, DI was introduced in 1948, causing some controversy but rapidly coming into use. The Japanese special ART law came into effect in March 2021 and stated that 'necessary legal measures will be taken within a target of roughly two years' regarding the right of donor-conceived people to know their donors. DI has continued retaining the practice of allowing anonymous sperm donors, and many voices have been raised in Japan against the abolition of donor anonymity to protect the masculinity of infertile men and donors' privacy.

The two countries differ in terms of the recognition of kinship. In Japan, kinship is recognised traditionally through the father-line, which makes producing a male progeny of utmost importance to couples and their extended families. In Norway, kinship is recognised bilaterally. Research shows that in countries where sperm donation is viewed as less acceptable, the male line is recognised as the sole inheritance line; this contrasts with countries where acknowledgement of the mother's line is more important than that of the father (Inhorn \& van Balen, 2002; Mehrabi, 2017). Still, in both Japan and Norway, 
sperm donation is less controversial than egg donation, which accords with the overriding principle that motherhood should never be questioned.

In both countries, women are culturally recognised as protagonists in terms of reproduction. It is generally taken for granted that women want children, and only those without children have to explain themselves to others (Ravn, 2005). In Norway, this was reflected in the latest Parliamentary debate, as discussed above, where ARTs were framed as part of the reproductive rights of women. In Japan, infertility was generally understood as caused by a barren woman, while infertility among men was silenced. Thus, if a couple failed to bear children, then a culturally approved remedy was for a man to divorce and remarry. As such, anonymity contributed to the silencing of male infertility when sperm donation became a practice.

A marked difference between attitudes toward ARTs in the two countries relates to the cultural norms of maintaining reproduction exclusively within marriage. In Japan, fertility treatments are offered to heterosexual married couples only. At the core, Japan has a family pattern that emphasises the birth of a son in the patrilineal system and within the bounds of legal marriage. Thus, increasingly later marriages in contemporary Japan have led to concerns about the rise of childless couples. Moreover, male infertility is a problem that is both silenced as if non-existent, and a matter of great concern. In Norway, however, childbirth likewise has been postponed during the last decades but is not in the same way connected to legal marriage or the patriline. ${ }^{6}$ Consequently, in Japan, access to ARTs is restricted to childless married couples, whereas, in Norway, unmarried couples, same-sex women couples and single women have gained access to ARTs on equal terms over time.

Egg donation had, however, been prohibited in both countries until very recently. A striking similarity between the two countries is that they recently and at the same time took a radical step in moving from restrictive to permissive regulations. The arguments in favour of such a change are simultaneously similar and different. In Japan, the central arguments lie in the low birth rate and the many couples who travel abroad for treatments that are inaccessible in their country. In the context of an ageing population and a declining birth rate, allowing IVF using donated eggs is congruent with the objective of the country to promote childbirth. The legal approval of gamete donation, including eggs, is viewed as a countermeasure to the declining birth rate. Lawmakers and politicians have never argued for access to donated gametes as an issue of gender equality or human rights. Little attention is paid to the welfare of donor-conceived children or the right of same-sex women couples and single women to bear children. Thus, ART access remains denied to them.

In Norway, the argument that the country needs more children was also valid in the 2020 Parliamentary debate, but more emphasis was given to women's individual rights for access to treatments that are available 


\section{2}

worldwide. Moreover, access to ART treatments, including egg and sperm donation, was extended to single women following the earlier extension to same-sex women couples. The overall arguments in the Parliamentary debate was centred on the goal of becoming a modern country by utilising available technologies instead of lagging behind, and that all women should have the right to access these technologies equally within the public health system.

In both countries, the argument for permissive regulations of gamete donation aims to put an end to fertility travel outside of the country to gain access to treatments that are not permitted in one's country. Interestingly, the argument that the treatments are safer in one's country than abroad is equally argued in Japan and Norway.

Finally, an interesting point of comparison is that when Norway included ART regulations under the new and more comprehensive Law on Medical Use of Biotechnology in 1994, the first paragraph states its purpose as follows:

The purpose of this Act is to ensure that the application of biotechnology in medicine is utilised in the best interests of human beings in a society where everyone plays a role and is fully valued. This shall take place in accordance with the principles of respect for human dignity, human rights and personal integrity and without discrimination on the basis of genetic background, on the basis of ethical norms relating to our western cultural heritage. [emphasis added] ${ }^{7}$

The Parliament reached a consensus in 1994 that the law should be based on ethical principles (as opposed to medical or scientific reasoning) and primarily on the principle of the equal value of all human beings. After the rejection of a proposal on Christian values, the voters then reached an agreement on the statement 'our western cultural heritage' (Melhuus, 2012, p. 63). An actual definition of this heritage was not included in the statement; neither does it refer to a long-lasting debate about Eastern versus Western values (see, e.g., Wong, 2008). The Japanese ART law does not include similar general statements.

As previously mentioned, ARTs refer to technologies that are accessible across the world. In discussions of globalisation, there has been a continuous debate on the relationship of global trends versus local cultures and traditions, including arguments of eastern and western values versus the idea of 'universal human values' (Inda \& Rosaldo, 2008). Some have argued that in a time of increasing global exchange there is a need for global ethics, but still, the case of ART regulations reveals marked differences between nations (Bleikli et al., 2004). Japan and Norway differ according to their cultural traditions of family patterns, kinship and gender relations. Nonetheless, when analysing the debates and policies of gamete donation, an overall argument is that policies of egg and sperm donation have differed 
over time due to cultural understandings of a basic gender difference - an argument that is similar in both countries.

\section{Notes}

1 See Melhuus (2012, pp. 47-70) for a thorough analysis of the Norwegian legislation of ARTs until 2011.

2 Until 2020, all pregnant women were offered an ultrasound examination by week 18 , that is, after the limit of free abortion at week 12. In addition, the Parliament requested the government to enforce access to ultrasound examinations during the first trimester and within the public health service system.

3 https://www.stortinget.no/no/Saker-og-publikasjoner/Vedtak/Vedtak/Sak/?p= 77395. Vedtak 621.

4 Retrieved from https://www.bioteknologiradet.no/english/ (accessed 5 November 2020).

5 Retrieved from https://www.aftenposten.no/norge/politikk/i/zJ3E4/klart-flertallsier-ja-til-aa-aapne-for-eggdonasjon-i-norge (accessed 5 November 2020).

6 Retrieved from https://www.ssb.no/en/statbank/list/fodte (accessed 30 November 2020).

7 Retrieved from https://app.uio.no/ub/ujur/oversatte-lover/data/lov-19940805056-eng.pdf (accessed 30 November 2020). Italics inserted by authors.

\section{References}

Adelson, N., Butt, L., \& Kielman, K. (Eds.). (2013). Troubling natural categories: Engaging the medical anthropology of Margaret Lock. McGill-Queen's University Press.

Becker, G. (2000). The elusive embryo: How women and men approach new reproductive technologies. University of California Press.

Bleikli, I., Goggin, M.L., \& Rothmayr, C. (Eds.). (2004). Comparative biomedical policy: Governing assisted reproductive technologies. Routledge.

Castro-Vàzquez, G. (2017). Intimacy and reproductive in contemporary Japan. Routledge.

Engeli, I., \& Allison, C.R. (2017). Governing new reproductive technologies across Western Europe: The gender dimension. In M. Lie, \& N. Lykke (Eds.), Assisted reproduction across borders: Feminist perspectives on normalizations, disruptions and transmissions. Routledge.

Franklin, S. (1997). Embodied progress: A cultural account of assisted conception. Routledge.

Gingrich, A., \& Fox, R.G. (Eds.). (2002). Anthropology, by comparison. Routledge.

Haraway, D.J. (1988). Situated knowledges. The science question in feminism and the privilege of partial perspective. Feminist Studies, 14(3), 575-599. https:// doi.org/10.2307/3178066

Harper, J.C., Kennett, D., \& Reisel, D. (2016). The end of donor anonymity: How genetic testing is likely to drive anonymous gamete donation out of business. Human Reproduction, 31(6), 1135-1140. https://doi.org/10.1093/humrep/dew065

Inda, J.X., \& Rosaldo, R. (Eds.). (2008). The anthropology of globalization: A reader. Blackwell Publishing.

Inhorn, M., \& van Balen, F. (2002). Infertility around the globe: New thinking on childlessness, gender, and reproductive technologies. University of California Press. 
Japanese Institution for Standardizing Assisted Reproductive Technology. (2021). Background of IVF implementation. https://jisart.jp/about/external/how/

Jasanoff, S. (2005). Designs on nature: Science and democracy in Europe and the United States. Princeton University Press.

Katagiri, Y. (2020). Shikija no me’Zentai no yaku 6\% ni noboru seishoku iryō no gennjyō [Current status of assisted reproductive technology, which accounts for about $6 \%$ of all births]. Japanese Medical Journal, 5014, 65. https://www. jmedj.co.jp/journal/paper/detail.php?id=14665

Kinjō, K. (2012). Dai 2 shō Haigushi teikyū [Chapter 2 Gamete donation]. In N. Suganuma, \& S. Morinaga (Eds.), Sirizu Seimei rinrigaku: Seishoku iry [The Japanese Bioethics Series: Reproductive medicine] (pp. 24-44). Maruzen Publishing.

Kobayashi, T., Sugiura, N., \& Hatano, D. (2020, 7 October). Internet sperm donations increase, along with dangers. The Asahi Shimbun. http://www.asahi.com/ ajw/articles/13795940

Kurahashi, K. (2017). Dansei funin to dansei sei-‘Oi’ to i.u. shiten wo yomu [Male infertility and masculinity: From the perspective of 'ageing']. In H. Yui, \& Y. Matsubara (Eds.), Studies for inclusive Society 16. Reproduction: Population policy and gender. Ritumeikan University.

Lie, M., \& Lykke, N. (Eds.). (2017). Assisted reproduction across borders: Feminist perspectives on normalizations, disruptions and transmissions. Routledge.

Lock, M.M. (1993). Encounters with aging: Mythologies of menopause in Japan and North America. University of California Press.

Mehrabi, T. (2017). Matters of donation and preserved relations: Co-construction of egg donation and family structures in Iran. In M. Lie, \& N. Lykke (Eds.), Assisted reproduction across borders: Feminist perspectives on normalizations, disruptions and transmissions (pp. 189-204). Routledge.

Melhuus, M. (2012). Problems of conception: Issues of law, biotechnology, individuals and kinship. Berghahn.

Minami, T. (2016). Legislation toward allowing all donor-conceived offspring the right to know their origin: The cases of Japan and Victoria, Australia. Journal of Philosophy and Ethics in Health Care and Medicine, 10, 13-22.

Osaki, T. (2020, 27 December). 'DM if interested': Sperm donors in Japan operate in a grey zone. Japan Times. https://www.japantimes.co.jp/news/2020/12/27/ national/science-health/japan-sperm-donors/

Ravn, M.N. (2005). A matter of free choice? Some structural and cultural influences on the decision to have or not to have children in Norway. In C.B. Douglass (Ed.). Barren states: The population 'implosion' in Europe (pp. 29-47). Berg.

Robertson, H. (2018, 1 October). Sperm shortages force Tokyo hospital to end donor insemination. Bionews 969. https://www.bionews.org.uk/page_138777

Score of life (2014, 27 April). Egg donation, unsuccessful legal development, women traveling abroad seeking 'eggs' [Original title: Jinsei no gakufu (3) 'Ranshi teikyō' Susumanu hōseibi, 'Ranshi' motomete Kaigai he wataru joseitachi]. Sankei News. https:/www.sankei.com/west/print/140427/wst1404270075-c.html

Shirai, C. (2019). Genetic ties and affinity: Longitudinal interviews on two mothers' experiences of egg donation in Japan. East Asian Science, Technology and society: An International Journal, 12, 299-315.

Spilker, K., \& Lie, M. (2007). Gender and bioethics intertwined: Egg donation 
within the context of equal opportunities. European Journal of Women's Studies, 14(4), 327-340.

Takeya, K., (2008). Funin wo meguru shakai reikshiteki haikei to sono gensetsu [Social historical background and discourse surrounding infertility]. Department Bulletin Paper of Faculty of Education, 11, 25-32.

Tsuge, A. (2005). How society responds to desires of childless couples: Japan's position on donor conception. Pp Bulletin of Institute of Sociology and Social Work, 35, 21-34.

Van Dyck, J. (1995). Manufacturing babies and public consent: Debating the new reproductive technologies. Macmillan.

Wernick, A. (2020, 23 November). Japanese bill defines parenthood in fertility treatment cases. Bio News 1073. https://www.bionews.org.uk/page_153368\#: :text=A\%20bill $\% 20$ submitted $\% 20$ to $\% 20$ Japanese,use $\% 20$ sperm\%20and $\% 20$ egg $\% 20$ donation

Wong, A.E. (2008). Relocating East and West: UNESCO's major project on the mutual appreciation of Eastern and Western cultural values. Journal of World History, 19(3), 349-374.

Yamamoto, N., Hirata, T., Izumi, G., Nakazawa, A., Fukuda, S., Neriishi, K., Arakawa, T., Takamura, M., Harada, M., Hirota, Y., Koga, K., Wada-Hiraike, O., Fujii, T., Irahara, M., \& Osuga, Y. (2018). A survey of public attitudes towards third-party reproduction in Japan in 2014. PLOS ONE, 13(10). https:// doi.org/10.1371/journal.pone.0198499

Yui, H. (2016). Taigai jusei no rinshō ōyō to Nihon jusei chakushō gakkai no setsuritsu. [Clinical application of in vitro fertilization and establishment of Japan Society of Fertilization and Implantation]. Journal of History of Science, Japan, 55(278), 118-132. 


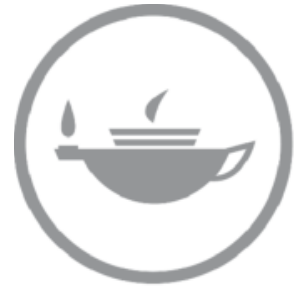

Taylor \& Francis Taylor \& Francis Group http://taylorandfrancis.com 
Part V
Dialogue 


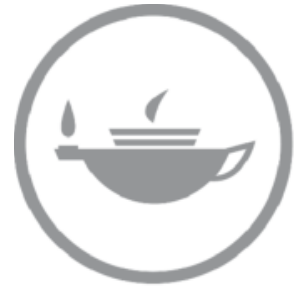

Taylor \& Francis Taylor \& Francis Group http://taylorandfrancis.com 


\title{
13 Becoming a feminist academic in Japan and Norway: A dialogue with professors Masako Ishii- Kuntz and Agnes Bolsø
}

\author{
Jennifer Branlat, Agnes Bolsø, and \\ Masako Ishii-Kuntz
}

\section{Feminist dialogues}

The following dialogue between Masako Ishii-Kuntz, Professor Emerita and Vice Dean of Ochanomizu University (Japan), and Agnes Bolsø, Professor Emerita at the Norwegian University of Science and Technology (NTNU, Norway), began in virtual space, as did most meetings during the COVID-19 pandemic, in late 2020 and continued to June 2021. Its purpose was to explore the ways in which these two professors in Gender Studies view their professional trajectories in a wider perspective than that of the traditional career narrative. The dialogue sets into play questions of early lived experiences from childhood, the possibility or impossibility of finding a 'home' in feminism at various points in time and of pioneering academic work in the highly interdisciplinary and international field that Gender Studies is today.

A dialogical approach such as the one featured here has two principle aims. First, it opens up a space for the participants' existential 'struggles of becoming' to take form (Frank, 2005, p. 968). Rather than Profs. Ishii-Kuntz and Bolsø presenting themselves solely through categories such as 'feminist academic' or 'sociologist,' which emphasise professional identities over personal, the aim here was to show how the professional and personal are intertwined and interrogate each other. Second, dialogical enquiry allows for stories to emerge in a shared space - in this case a virtual one - and during moments of contact with others. Finally, the dialogical welcomes the influence that all speakers have on each other's storytelling processes.

Both born at the beginning of the 1950s into quite non-traditional families during the 'housewife era' of the post-war period, Masako IshiiKuntz and Agnes Bolsø embarked on journeys, which, although geographically distinct, resonate in many respects. Professor Ishii-Kuntz grew up in the small fishing town of Rumoi, Hokkaido, the most northern island of Japan. She pursued her undergraduate and graduate studies in Family 
Sociology in the US. After 20 years at the University of CaliforniaRiverside, she returned to Japan with the strong desire to work with the motivated young women at Ochanomizu University, where she led the Institute for Gender Studies from 2015 to 2020 and is now Trustee, Vice President and Professor (Emeritus). Her research concerns gender dynamics both in families and in the workplace, with a particular focus on Japanese fathers' involvement in housework and childcare. A major part of her Japanese fatherhood research has stemmed from her involvement in an advocacy group for shared parenting, which was the driving force for the 1992 law giving men the right to take family leave from work. Her research on the 'Ikumen' phenomenon - 'cool' fathers who are actively involved in caring for their own children - has been instrumental in establishing a space for men and masculinity in the field of Gender Studies.

Prof. Bolsø grew up on a coastal farm in Ørland, Norway, as the daughter of a wartime sailor and midwife. She has been head of the Centre for Gender Studies at NTNU, editor of The Norwegian Journal of Gender Studies and involved in the development of Norwegian feminism, Women's Studies and Gender Studies since the 1980s. After beginning her university studies in mathematics, she was quickly politicised in the 1970s and went on to study Sociology and History. She obtained practical training as a researcher in agricultural and rural studies before specialising in Gender Studies. She has generated a thematically broad academic output on gender, sexuality, and power and politics. Prof. Bolsø is currently pursuing research on trans bodies and femininity, enquiring into the role of symbolic gender in trans transformations.

The dialogue between Agnes Bolsø and Masako Ishii-Kuntz was mediated and edited by Jennifer Branlat, whose questions appear as headlines throughout the dialogue. Jennifer is a post-doctoral researcher and feminist educator at the Norwegian University of Science and Technology.

\section{How did you arrive at where you are today?}

\section{AGNES BOLSØ:}

In terms of career, I would say it was random. First, I had planned on becoming a math teacher and then politics erupted onto the scene in the 1970s, and I realised I couldn't save the world with mathematics. I changed to History and Sociology. As a student in Sociology, I had a teacher who belonged to the same political movement as me and hired assistants to do data processing on punch cards. I was coding for him, but I also really enjoyed his teaching. As a result, I ended up moving into his field of research, 
which was Rural Sociology. I did both my Bachelor's thesis and my Master's thesis with him as a supervisor. I think I was still planning to become a teacher when politics took hold of me during my Master's. I proletarianised myself and that's how I came into research. I was still working in agriculture and five months pregnant with my son when I was recruited as a researcher for the Center for Rural Research. I was always a feminist, socialist, communist and supporter of green politics from the 1970s onward. It was a whole package. A very exciting journey.

It was difficult to get funding for sexuality research at the Center for Rural Research, so I jumped to Gender Studies, and that was where what you could call a 'career' started. That was also accidental. I got a Ph.D. and filled in as a professor until I obtained a permanent post. I think I was much less strategic than I was just taken by the events.

\section{MASAKO ISHII-KUNTZ:}

In my case, I grew up in a family where my mom didn't really do much in terms of childcare or housework. It was my father who performed all the domestic tasks. As a result, I grew up questioning why that was the case, because in my friends' families it was their mothers who were taking care of them. In Japan (at least in my childhood days), children bring bento lunches from home, and it was the case that my lunch never seemed to look as attractive as those of the other girls, whose bentos were made by their mothers. I grew up thinking that something must be wrong with me or my family. By the time I graduated from high school, I imagined that my college education should take place somewhere outside of Japan because I knew that I wouldn't be able to find the answers in Japan. I left Japan in the early 1970s and started my college education in the US, in the wake of the 1960s civil rights movement.

After my undergraduate degree, my parents said that I had reached the end of their financial assistance, so I had to get a job but didn't have a work visa in the US. I had to come back to Japan. I began working for an English language newspaper, and it was then that I was exposed to gender discrimination that existed in Japanese working life. At the time, I didn't want this to be my future, so I worked, saved money and was able to go back to the US after four years of working. I remember thinking that English language newspapers would be liberal, but my experiences ended up being quite the opposite. After four years, I 


\section{Jennifer Branlat et al.}

entered my Master's program, and after my Ph.D. I decided to stay in the US because of my experiences with discrimination at the newspaper company. At the time, I didn't want to come back to Japan at all. I ended up getting a job in the Sociology Department at the University of California, Riverside [UCR]. 'Pressure cooker' would be the words to describe my years at UCR because of the 'publish or perish' research environment. I survived this battle to receive a tenure in 2003, but I began to feel that something was missing in my career, namely teaching for the future generations. Throughout my career in the US, I maintained a part-time teaching post at Ochanomizu University, one of the two national universities in Japan for women. For several summers I would teach a graduate seminar, and I came to be quite fascinated by the quality of the female students in terms of their seriousness towards learning and their high level of motivation. I felt like my mission in life was to return to Japan to work with these brilliant students and contribute to their future development. The fact that I am in Japan now and have been for the last 15 years was something that I didn't plan on. [laughs] You just never know.

\section{AGNES BOLSØ:}

It seems that both of us were embarrassed about things we are quite proud of today. Your story about your norm-breaking parents reminds me of my mother. I feel a deep solidarity with the women that came before me: My free-spirited aunt but also my mother, who was more grounded. She was a nurse during the war and helped evacuate patients by boat from the local hospital to the islands during the German bombing of Kristiansund in 1939. It was in this context that she helped a woman give birth in fairly dire circumstances. This event affected her, and she ended up going to a midwife school in Oslo. She worked as a midwife during the rest of the war. My mother was tough.

My father was a convoy sailor during the war and like so many men, under the constant threat of torpedo strike, he had a breakdown and had to be hospitalised. He ended up falling in love with a nurse in the hospital, and when my mother happened to find one of their love letters, she put on her coat and left for Trondheim to seek legal help. My father told her she couldn't obtain a divorce since they had children, but the lawyer told her differently. She raised us alone. She was a feminist, but she probably never said the word in her life. She divorced my father in 1953, the year I was born. No one we knew was divorced in 1953. The one memory - even though there are so many - I have of my mother 
being different from other mothers was when we went to church. She wasn't a Christian, but there was no entertainment in the village of 300 people so she went to church to listen to the organ and the singing. She loved to sing, and she knew all the words. She would sit straight up - she was quite tall - and she sang the absolute loudest of the congregation. Always. At the time I was ashamed but now, thinking about it, I'm so proud. Then later when she took a position in a more remote area, she bought herself a moped, a helmet and big gloves [laughs].

\section{How are the words 'feminism' and 'gender' used in Japan?}

\section{MASAKO ISHII-KUNTZ:}

Beginning in the late 1990s and early 2000s, there was a period of five or six years of the so-called 'gender bashing' or 'gender-free bashing' in Japan. Anything and everything related to gender came under scrutiny. I was, in fact, advised not to use the word 'gender' when I was invited to give a talk. I was quite offended, as you can imagine. In many cases, the words 'feminist' and 'feminism' have been reserved for academics to a great extent. The terms have not been used on the same level among the general public. Perhaps that's why we do encounter criticisms here and there levelled against feminist philosophers or thinkers in academic sense, but we don't hear muchelmets' who organised a series of demonstrations, the most well-known of which involved storming into the Diet, the National Assembly, wearing pink helmets. Those sorts of women represent the very active or radical women who are opposed to the government, which at the time opposed the idea of birth control pills. In those days, though, we were not using the word 'feminism' at all to describe these women. Rather, the words 'Women's Lib (Liberation) Movement' were used to describe female activists in those years. So, in a sense, these women were known as activists for women's causes, not feminists per se.

\section{What about the term feminism in Norway?}

\section{AGNES BOLSØ:}

Today feminism in Norway can be anything. There are all sorts of feminisms. I think we could just be pragmatic about the word 'feminism' and let it reflect the context: the relevant cause/topic and 


\section{Jennifer Branlat et al.}

those who are involved, where and when. Sometimes it is women's issues, sometimes it's gender issues and sometimes sexuality or feminism itself that's at stake. The choice of word depends on the concrete context. All the words are contestable, and it's quite difficult to find a word that is uncontested. I became a feminist, a conscious feminist anyhow, in the early 1970s. I belonged to the communist/socialist student left at the time, and feminism to me was a bourgeois word used among the liberal right. This was not altogether true, as I see it in hindsight! But to me it had roots in the suffrage movement, which was primarily a bourgeois, upper-class political movement. Feminism first arrived with the French Revolution and was connected to the acquisition of civil rights. When the leftist women's movement came along in the 1970s, it was for me all about liberation - women's liberation but also everybody's liberation from the capitalist system within which the bourgeois feminist had secured her rights.

\section{How about feminism and class in Japan?}

\section{MASAKO ISHII-KUNTZ:}

I think that's quite similar within the Japanese context in which highly educated, well-to-do middle- to upper-class women were very active in pursuing their ideals or expressing their opinions with respect to the use of birth control pills.

\section{Feminism today - is it still about class?}

\section{AGNES BOLSØ:}

Throughout history, if you look again at the suffrage movement, the upper-class women who participated were labelled feminists and really had a hard time of it. Feminism was a derogatory label. They were not seen as proper women - they were called men in skirts, sometimes hardly considered humans since they were understood as neither 'man' nor 'woman.' There's an echo of it in today's boardroom feminism, or Gucci feminism as it is sometimes called. Corporate feminists don't want to use the words 'feminism,' or 'women's liberation' because they are first and foremost meritocrats. It's all about competence and qualifications and the right to have a position based on competitive processes. If today's feminism is a very broad term, 
it encompasses all sorts of ideas about women and society, and the relationship between men and women and capitalism. It lends itself to different kinds of analysis. That's why I say we have to be pragmatic feminism cannot mean one thing. When we say feminism, it could literally mean anything that has to do with equality, where women and men are involved. I would say, though, that the echo of the derogatory is still very much in place.

\section{MASAKO ISHII-KUNTZ:}

I think, in case of Japan, the word 'feminism' or even 'gender,' or 'femininity' and 'masculinity' - all of these have been used by bourgeois women, but at the same time by men who are against anything to do with women. Politicians, male politicians, or those espousing dominant culture have used, for example, gender in the gender-bashing context and feminism the same way. In that sense, there are different kinds of feminism that exist in Japan, too. But as far as being the target of criticism, all feminisms have become the target of both politicians and upper-class men.

\section{What was your experience of attending university during the tumultuous 1970s?}

\section{AGNES BOLSØ:}

During this period in Norway, it was a time of fagkritikk or, to put it in English, critiquing the disciplines. There was nothing - and I mean nothing - about women's issues on the reading lists. In History and Sociology, we created our own courses, seminars and reading lists [shows the papers from her personal archive]. In History, for example, we made a course on women in working life and the Norwegian women's movement. We actually received university credits for this course, which was established with the help of a socialist professor in the History Department who helped obtain official recognition. There was another from Sociology called 'women and production' that discussed women as the reserve army under capitalism and women's relationship with the trade unions. We created it and we also did the teaching as undergraduate students [laughs]. There was a critique in every discipline that not only women were invisible, but the working class was invisible, and rural people were invisible. It was the white upper-class man that was visible in every discipline. This effort to make women and women's situational historical contexts visible was deeply empirical. 


\section{MASAKO ISHII-KUNTZ:}

I have to admit that you were ahead of me in the 1970s in your undergraduate studies. When I was an undergrad at an American college in the 1970s, the American women's rights movement was in full swing from the 1960s. A couple decades later, we read a book that I remember quite well, Carol Gilligan's In a Different Voice [1982]. This book acted as an eye-opener for me because it helped me better understand the ethics of care and how it is internalised by women. In understanding my own family, especially my father's involvement in childcare, I thought Gilligan's views could also be adopted by men who care. Gilligan was occasionally criticised for not providing data to support her arguments, but even if I were to read her work for the first time now, I would still learn a great deal about the ethics related to domestic care work. In my college days, we were just given the readings and were asked to read them. Through the readings we came to discover many dimensions of women's issues, but we didn't create courses or reading lists like Agnes did [laughs].

\section{Was feminism part of your motivation to build a career in the academy?}

\section{AGNES BOLSØ:}

For me, it was all about women and women's liberation, increasing women's strength in all areas of society. I wasn't using the word 'feminism' at the beginning. I started out as an applied researcher in Agricultural and Rural Sociology funded by the government and by agricultural corporations and organisations. There was a lot of work to do to give rural women confidence and in bringing feminist points of view into all sorts of research topics. We women did not obtain the right to inherit a farm until 1978, which was quite late. Prior to that, family farms were passed to the son, which means it took quite a while to change attitudes and get boys and girls to be treated equally in agriculture. My research was related to a deep gender division in agriculture, and I saw it as my task to work to strengthen women's position in rural areas. 'Feminism' as a concept was not a part of that picture. It was about women's confidence and rights. 


\section{MASAKO ISHII-KUNTZ:}

As I said, I grew up thinking that there was something wrong with my family because of my father's heavy involvement in housework and childcare. I didn't even know the word 'feminism' then, of course. But looking back, I definitely became fascinated by feminists' writings in pursuit of my childhood questions. So, yes, feminism was part of my motivation in building my career as a sociologist. When I began to do research on housework and childcare during graduate school in the 1980s in the US, I was told by many male professors that there wasn't much to research in the division of household labour. They claimed the topics of housework and childcare were too 'domestic,' that they were 'women's issues' and that it was important to set my sights higher. I remember being warned by American male professors that conducting research on housework and childcare was most certainly not the overarching research theme that I should be pursuing. But given my childhood experiences and being strongly influenced by feminists' thinkers, I remember feeling that I must find the answers to explain the phenomenon of gendered division of household labour.

\section{Which aspects of women's situation did you try to make visible in your research?}

\section{MASAKO ISHII-KUNTZ:}

In the 1980s when I was interviewing women who were trying to build certain careers, I heard them saying over and over, 'I have to be a man to succeed.' It was quite commonplace, you know, that their partners were not helping them at all at home. Interestingly, it was their mothers who were helping them to raise their kids or with whatever household tasks that needed to be completed. Those career women were forced to be the front runner: Embodying a form of masculinity, the ability to compete or showing off that they could do just as much or even better than men. In many respects they had to present themselves as men. It's also not as common in Japan to seek domestic help. I think there is a strict line between what's considered public and private. Many Japanese 
people believe that family falls completely within private domain and therefore don't wish to bring outsiders into their private space. That leaves restricted possibilities for who can help with children and housework. That's why these domestic tasks fall on the mother. Given these domestic responsibilities that have been falling on women, I felt what I could do through my research was to discover the 'caring' aspects of fathers. I believed that mothers' experiences of childcare stress and anxiety can be alleviated through their partners' involvement in domestic tasks. Thus, in my research, I have identified both work- and family-related factors affecting men's involvement in childcare and housework. I have also examined how men's housework and childcare would influence women's psychological well-being. Most recently, I have been involved in a research project that examines 'caring masculinity,' which rejects men's domination and its associated traits and embraces values of men's care as positive emotion and relationality. Thus, you can say that my feminist approach has been not only for the benefits of women but for those of men as well.

\section{AGNES BOLSØ:}

I think I touched on my commitment to bringing women's voices into research in what we tried to accomplish at the Center for Rural Research. After that, there was a theoretical change, and sexuality came to the forefront with two big research programs through The Research Council of Norway - I had funding for both of them. They were called Gender in change [Kjønn $i$ endring] (1996-2001) and Gender Studies: Knowledge, limits, change [Kjønnsforskning: Kunnskap, grenser, endring] (2001-2008). It wasn't so much women's situation I was interested in but rather the ways in which sexuality, eroticism and the symbolic aspects of gender are deeply coded into culture. The symbolic aspects of gender are things that men and women, whether straight or queer anyone can play around with them. They reveal that masculinity doesn't have to be attached to men. Around this time, the notion of 'women's situation' became old-fashioned sounding, particularly in the context of the welfare state with its benefits for both men and women via parental sharing and the dual-earner model. The welfare state made women essential to the family economy and has facilitated male parenting. It's no longer a question of women's situation. 


\section{Feminist theory - inspirational or instrumental?}

\section{AGNES BOLSØ:}

It was with Judith Butler that I started to be interested in theory. Feminist theory of course existed before Judith Butler, but as an applied researcher, I wasn't able to relate so much to feminist theory. I knew about it and was familiar with the ideas and discussed them, but in applied rural research it was women, men and women's rights and increased confidence for women that we were interested in. That was when I made a point of the fact that women who said they didn't drive the tractor actually did drive the tractor. They had to do it for practical reasons rather frequently, and so they did it. I realised that they actively took part in portraying their role and importance as less than it was in reality. Women taking part in their own diminished positioning started to puzzle me more and more, and I needed more fine-grain tools and foundations for thinking about gender, and women and men, so feminist theory provided a way in. By this time, men's studies had come along, and in combination with Butler's deconstructing of man and woman altogether - that was really something. Something new and very compelling. But I think perhaps the most significant realisation for me came with a shift in my own sexual desires. Until my thirties, I had been straight, had children with a man that I loved and truly desired men. Falling in love with a woman and starting to desire women was quite puzzling and challenged me in ways that I wanted to study. I began to study this experience by reading about sexuality and the erotic, but also by doing my own project on my body. It was like going through puberty again. That was when I left rural studies. I suppose everything was driven by my own development. In any case, it wasn't possible at that time to obtain funding for projects on rurality and homosexuality. That's when I left rural studies and joined the group that had by then been formed at the university, the Center for Women's Research. It was both accidental and driven by my own desires.

It wasn't until the 1990s in the wake of Judith Butler's Gender Trouble [1990] that it really hit me that my theoretical understanding of 'man' and 'woman' meant something also for my academic research, and that there were already feminist theoreticians worth reading and listening to out there. You know, Aleksandra Kollontai and Rosa Luxemburg can only help us with some things and not others! It's quite embarrassing to admit this 
today, particularly when Gender Studies has become institutionalised and theory now occupies a central space.

\section{MASAKO ISHII-KUNTZ:}

It's fascinating to hear your reflections because there are so many overlaps. We were born and grew up in totally different cultures. Yet, I was also quite influenced by Judith Butler myself. During my undergraduate years, we also had to read Betty Friedan's Feminine Mystique [1963], and other pillars of feminism and feminist thought. In my readings of those texts, I really felt like, 'aha!,' this is the answer I've been searching for in relation to my family being different from others. It was an eye-opening experience for me, not just going to the US but reading some of the early feminist intellectuals' theoretical writings. Then, with Judith Butler, I was very taken with the concepts of deconstruction and performativity. I was also fascinated with the theoretical frameworks of R.W. Connell about masculinity. The concept of diverse masculinities rather than 'the masculinity' which has been presented in contrast with 'femininity' was especially inspirational in my pursuit of fatherhood research.

I find many similarities between Agnes' and my own experiences as undergraduates and then as Master's students. In particular, I also started out first and foremost as an empirical researcher. I read feminist writings, but not with the intent to use theories from those readings, but more or less as inspirational readings and guides. I was conducting empirical research as a family sociologist with a focus on gender inequality in families. I eventually came to realise the importance of theoretical thinking with respect to feminism and gender issues, but I definitely started out as an empirical researcher. In that sense, our backgrounds are quite similar. I remember reading interdisciplinary works - feminist perspectives on women - and I read those books without thinking too much. But I eventually came to think that I could apply theoretical dimensions to my empirical research. I was initially reading them for inspiration.

AGNES BOLSØ:

Empirically-grounded research, with few exceptions, was the founding principle for the Center for Women's Research in Trondheim, which was created to connect all these influences from different disciplines that had been raging throughout the 1970s and 
the 1980s in history, psychology, mathematics, biology - everywhere. The idea was that all these researchers from different empirical fields and disciplines would have a place to connect. Initially, we didn't teach our own courses; we coordinated the attempt to make women and the distinctions between women and men in the disciplines visible, as a consciousness-raising in a way. In the 1990s when Women's Studies became Gender Studies and 'feminist theory' was really established as a concept and a tradition, theory became central in the introductory classes to what now had become a field in its own right.

\section{What was the answer to your burning question about why your family was different?}

\section{MASAKO ISHII-KUNTZ:}

[laughs] There are many, many answers. Actually, my main discovery was that there was more than one answer for my question. But one of the eye-opening answers that I learned in Sociology courses in the US was that my dad probably lacked the resources to compete with my mom in terms of his social status, income and education level. He had an education to be sure, but my mother was so much more career-driven that she was too busy to pay attention to the children. My father on the other hand didn't really care about his career. He seemed to care more about keeping a diary of my milestones as a baby, what foods I ate and the things I enjoyed. I think my father cared more about his kids and less about his career.

\section{AGNES BOLSØ:}

Did you ever find out how it was possible for your father to be a norm breaker during the post-war period in Japan? I think it's an interesting topic for further research.

\section{MASAKO ISHII-KUNTZ:}

Perhaps he also didn't pay much attention about what a 'masculine' man should be or should not be doing. I remember asking him why he spends so much time with us and his answer was always 'because 


\section{Jennifer Branlat et al.}

I love you kids more than anything.' The fact that he was breaking the masculine norm of being a breadwinner at the time can be explained by his own childhood in which he often resented the fact that his own father was a very strong patriarchal presence in the family and thus was never involved in the care of his children (and there were seven of them!). This is also consistent with the complementarity socialisation hypothesis which suggests that if you grew up with a distant father, then you are more likely to be opposite by actively engaging in childcare. Now as I look back, his experiences can also be well explained by the caring masculinity concept.

Returning to my time at the university, and to the oppositions of my mentors during graduate school, I decided to pursue my research on the division of household labour in spite of the advice I received. I studied motherhood and fatherhood, family life, housework and childcare while at the same time reading feminists' theories. As a result, I not only have found answers for my own questions, but also became convinced that the research on domestic labour is more than just a women's issue. Consequently, I have been taking both gender and feminism seriously in order to further my research in this area.

\section{References}

Butler, J. (1990). Gender trouble: Feminism and the subversion of identity. Routledge.

Frank, A.W. (2005). What is dialogical research, and why should we do it? Qualitative Health Research, 15(7), 964-974.

Friedan, B., \& Friedman-Feminist Press Collection. (1963). The feminine mystique. Dell Pub. Co.

Gilligan, C. (1982). In a different voice: Psychological theory and women's development. Harvard University Press.

\section{Further Reading}

Bolsø, A. (2007). Approaches to penetration: Theoretical difference in practice. Sexualities, 10(5), 559-581.

Bolsø, A. (2010). Folk flest er skeive: Queer teori og politik [Most people are queer: Queer theory and politics]. Manifest.

Bolsø, A. (2012). Sociological discipline and the unruly erotic. Review of European Studies, 4(1), 94-106.

Bolsø, A. (2019). Kroppen og fantasiene om den. Det allmenne ved transkjønn [Bodies and associated fantasies]. Tidsskrift for kjønnsforskning, 43(4), 259-272.

Connell, R. (1987). Gender and power: Society, the person, and sexual politics. Stanford University Press. 
Connell, R. (2021). Masculinities. Routledge.

Ishii-Kuntz, M. (2009). Working-class fatherhood and masculinities in contemporary Japan. In S. Lloyd, A. Few, \& A. Katherine (Eds.), Handbook of feminist family studies (pp. 192-204). Sage.

Ishii-Kuntz, M. (2013). Sociology of child caring men. Minerva Publications.

Ishii-Kuntz, M., \& Lee, G.R. (1987). Status of the elderly: An extension of the theory. Journal of Marriage and the Family, 49(2), 413-420.

Kollontai, A., Dazhina, I.M., Mukhamedzhanov, M., \& Tsivlina, R.Y. (1984). Selected articles and speeches. Progress Publishers.

Luxembourg, R., \& Bukharin, N.I. (1972). Imperialism and the accumulation of capital. Penguin. 


\title{
Conclusion: Comparative perspectives on gender equality in Japan and Norway: Reflections and lesson learnt
}

\author{
Priscilla Ringrose, Masako Ishii-Kuntz, \\ and Guro Korsnes Kristensen
}

\section{Exploring gender equality}

The aim of this anthology was to understand how gender is intertwined in dimensions of family and home, education, media, technology, sexuality and reproduction in Japan and Norway by comparing these issues within and across the two national contexts. In doing so, we have approached the notion of gender equality from an open perspective, exploring the different forms and contents it embodies, over time and with reference to the wider global context. This chapter will reflect on the convergences and divergences we have found in all the dimensions explored, focusing especially on social and cultural conceptions of gender equality in Japan and Norway, as they were brought to light in this anthology. We will also discuss the empirical, methodological and theoretical lessons learned from the different explorations. We conclude with wider reflections relating to welfare and policy in both countries.

\section{Reflections: Chapters in review}

While the statistical comparisons outlined in the introduction suggest a stark difference in the status of gender equality in both countries, we suggest that our volume - which adopts qualitative approaches, supplemented by some quantitative studies - provides a much more complex and nuanced picture. The explorations of gender equality undertaken in this book break down any potentially reductive polarisations of the status of gender equality between Japan and Norway. We can illustrate this complexity with reference to several chapters which reveal a complex interplay of convergences and divergences across the two cultures. The chapter on trans and gender-diverse experiences in Japan and Norway, for example, showed that despite ostensible difference in trans rights, the maintenance of cisnormative institutional and cultural values is rife in both contexts. Informants reported a pervasive sense of non-belonging - nationally, socially and, for most, physically. 
In other chapters, we find convergences along several dimensions, alongside differences, which are often differences of degree. This was the case in chapters dealing with the dimension of work-life balance, as explored in the chapter on academia, which looked at the career trajectories of women and men professors in Japan and Norway. Here we find that in both contexts, male and female academics had to endure precarious job situations and found their domestic work and care situation challenging. However, domestic and care chores were much more challenging for women in both contexts, especially for Japanese women. Significantly, Japanese women also reported gender discrimination in academia, which was not the case reported by their Norwegian counterparts.

Other chapters also illustrate the complex interplay of convergences and divergences, such as in the area of reproductive tights. The chapter on Assisted Reproductive Technologies (ARTs) revealed strikingly similar patterns of legislation in both national contexts but a complex of similar and different motivations underlying them. This chapter explored the historical development of ARTs in Japan and Norway. In both Japan and Norway, a similar clear divide existed between the legality of sperm donation and the prohibition on egg donation. However, a radical change took place when both countries legalised egg donation within a similar timeframe - 2020 (Japan) and 2021 (Norway). The arguments in favour of such a change in both countries were simultaneously similar and different. In Japan, these included arguments relating to the low birth rate but which never deferred to the issue of gender equality or human rights. In Norway, the argument that more children were needed was also found in Parliamentary debates, but much more emphasis was placed on women's individual rights for access to treatments that are available worldwide.

All the chapters referred to in the anthology were the product of a complex process of cooperation between researchers in Japan and Norway, as described in our introduction. As noted there, cross-national research presents both pitfalls and many potential benefits. In terms of pitfalls, as Mangen (1999) asserted, researchers may face linguistic and cultural challenges in engaging with data from the other national context. This was the case in the chapter about masculinity in the Samurai film and Viking series. Both authors were from the Norwegian university, and despite being familiar with masculinity studies in Japan, they still had to rely heavily on Japanese colleagues for understanding the cultural nuances of the Japanese film script and for their invaluable knowledge of the wider generic phenomena of Samurai films in Japanese culture.

Challenges were also experienced when researchers from one context used methodological or theoretical approaches which their research partners were not so familiar with, or which were not so commonly used within their nationally inflected disciplinary field. However, our approach was generally to embrace these divergences and to accept that cross-cultural 


\section{Priscilla Ringrose et al.}

research must be able to leave room for differences, as well as to acknowledge the added value these differences confer. This is the case in the fatherhood chapter, which triangulated qualitative and quantitative methods - an approach which is less common in Norwegian gender studies, but which brought added depth and breadth to the discussion of fatherhood. This chapter achieved this added value by constructing and applying a multi-sample structural equation analysis developed by the Japanese researcher to both Japanese and Norwegian contexts. The chapter looked at how intersectional dimensions such as employment status, education and age predict men's gender ideology and influence men's childcare involvement. The results meant that new knowledge about Norwegian fathers was generated thanks to the statistical model proposed by the Japanese researcher. The chapter concluded that Japanese men who have younger children and whose spouse's income is higher are more likely to be involved in childcare, whereas, for Norwegian fathers, their childcare involvement was not influenced by these sociodemographic factors.

In line with this, and as Salway et al. (2011) noted, there are many ways in which cross-national comparative research provides added value. They also point out that such research can strengthen both the rigor and utility of research since such work tends to prompt researchers to engage in both ideological and methodological reflexivity. Such ideological reflexivity will be discussed at the end of this conclusion when we take a step back and look at the ideological differences underlying Japanese and Norwegian state policies as related to gender equality. However, more relevant to our individual chapters is the contention that cross-cultural research raises awareness of the need to take on board both the sociopolitical contingencies of the local histories as well as wider social and political contexts and understandings (Salway et al., 2011). This is the case in the chapter on the Japanese and Norwegian home, which focused on cultural understandings of the home. On the one hand, this chapter looked at the particularities of both national contexts from the 19th century onwards, engaging with such national phenomena as the housewife schools which were set up in Norway from the 19th century, and the contents of the Meiji Civil Code (1889) which reinforced paternal authority within the family. On the other hand, the comparative dimension also compelled the authors to consider the broader cultural understanding of the home in much wider Western and Eastern historical perspectives, relating to global phenomena such as modernity, industrialism and capitalism.

\section{State ideologies}

Finally, we return to broad ideological strokes referred to above, looking at state ideology in both contexts in the light of some of our overall findings. While this volume interpellates a range of convergences in forms and/or 
contents of gender equality across both contexts, it also points to some fundamental differences between the two contexts that derive from its governmental systems. While the Norwegian and the Japanese governments both have stated aims to improve gender equality, the fact that Norway has an advanced welfare state (which has been associated with the concept of state feminism) means that the value of gender equality has for decades been systematically applied to a range of policy areas, especially family policy. Within the framework of the welfare state in Norway, family policy is the most important way to become gender equal. In Japan, we also find a focus on gender equality in government policy but the level of importance placed on it is not high relative to Norway. In recent years, the Japanese government has been implementing many policies with the aim of achieving better gender equality in a range of areas, such as welfare provision for elder care and single parents. However, in the following we look at why the Japanese policies relating to dimensions of equality may not have been improving the lives of its citizens to the same extent as gender equality and other equality policies have done in Norway.

There are several reasons we can identify that could explain why gender equality policies have not had an optimal impact on the daily life of Japanese citizens. One reason for this is that while Japan can to a certain extent be considered to be a welfare state, its welfare system is not as extensive or far-reaching as its Norwegian equivalent. Secondly, gender equality policies in Japan have not been as radical as those in Norway. While for example the Japanese government has encouraged more women to join the labour market by creating policies to promote women's active participation in society, in Norway more radical approaches have been favoured, such as a quota system to encourage more women to be part of corporate boards. A third reason that might explain why gender equality policies in Japan may not be so effective in practice is that Japanese citizens may not feel entitled to welfare policies as much as Norwegian citizens do. This lack of a sense of entitlement relative to Norway may partly be explained in relation to the Norwegian tax system. Norwegians pay high taxes, which in turn makes them feel that they are owed welfare benefits, which is not the case in Japan. An additional factor, as discussed in the home chapter, is that Japanese and Norwegian citizens have very different relationship to the private spheres. Japanese citizens are very protective of their private spheres and reluctant to reveal any private issues which might suggest that they need welfare. This is especially the case when it comes to sensitive issues such as domestic violence, but also when it comes to other areas such as poverty, meaning that some individuals may find it difficult to admit their need for welfare benefits. The degree of entitlement is different: In Norway welfare is associated with rights, while in Japan welfare is inflected with failure and shame. 


\section{The idea of gender equality}

Perhaps the most glaring difference that emerged from this volume is the different relationship Norwegians and Japanese people have to the very idea of gender equality. In Norway, gender equality does not need to be defended or reflected on. It is part of the fabric of social and political society. In Japan, gender equality is more of an issue, rather than something that is taken for granted. This is illustrated, albeit on a light-hearted level, in Chapter 8 . In this chapter, gender equality is presented as an ideal in the Samurai film, whereas in the Viking series it is presented as an idea that is so pervasive and 'extreme' that it has become laughable.

Finally, turning back to the global statistics that opened our volume, we note that the Japanese government's relation to both understandings and policies of gender equality is highly influenced by Japan's relatively low rankings in global surveys relating to gender equality. These rankings have made a difference in how politicians perceive gender equality and in the belief that they, put simply, 'need to do something about it.' The impetus for change in gender equality is thus impacted by Japan's perception that it needs to improve its global image. Surveys such as the World Economic Forum's Gender Gap Report (2021), in which Japan was ranked 120th (while Norway was ranked second), means that the government is sensitive about global data. The Japanese government has made moves to revise policies accordingly, but in doing so they are responding to outside pressures rather than being concerned about making gender equality happen for its own sake. In Japan, therefore, the government to some extent pays lip service to gender equality. And while the Norwegian government may also respond to external pressures, it actively keeps up its global image as a model of gender equality, even going so far as to invest funds into exporting gender equality to other parts of the world. So, in both Japan and Norway, gender equality is a matter not only of policy and practice, but also of perception, image and, by default, a question of self-interest.

\section{References}

Mangen, S. (1999). Qualitative research methods in cross-national settings. International Journal of Social Research Methodology, 2(2), 109-124. https:// doi.org/10.1080/136455799295087

Salway, S.M., Higginbottom, G., Reime, B., Bharj, K.K., Chowbey, P., Foster, C., Friedrich, J., Gerrish, K., Mumtaz, Z., \& O’Brien, B. (2011). Contributions and challenges of cross-national comparative research in migration, ethnicity and health: Insights from a preliminary study of maternal health in Germany, Canada and the UK. BMC Public Health, 11(514). https://doi.org/10.1186/1471-245811-514

World Economic Forum. (2021). The Gender Gap Report 2021. [Report]. http:// www3.weforum.org/docs/WEF_GGGR_2021.pdf 


\section{Index}

Note: Italicized page numbers refer to figures.

Aarseth, H. 22, 48

Abe, S. 176-178, 185

academic housework 106

Act on Promotion of Women's

Participation and Advancement in the

Workplace (Japan) (2016) 30

activism 97-100; HIV/AIDS 159;

LGBTQ 2, 159, 170

advertisements 139-151; 'noisy

children' trope in 147; content analysis of 140-141; happy family

myth in 148-149; Japanese salarymen in 141-143; Japanese versus

Norwegian 148-150; marginalisation

of women in 149; Norwegian

working mothers in 143-144;

pandemic-era 144-146; pre-pandemic

141-144; work-related 141-146

alienation 93-96

Anderson, B. 21

Ando, K. 193

anti-welfare state 128

Asahi Shimbun Corporation 141

assisted reproduction technologies

(ARTs) 3, 4, 9, 191-203;

convergences and divergences in 225;

cross-cultural studies 192-193; egg

donation 194-195, 198, 200-201;

gamete donation 196-197; and

globalisation 193; and menopause

192-193; overview 191-193;

regulations in Japan 193-197,

200-201; regulations in Norway

197-200, 200-201; sperm donation

193-194, 200-201; in vitro

fertilisation (IVF) 191, 196
At Home: An Anthropology of

Domestic Space (Cieraad) 16

attachment 15, 133, 161

banking model of education 88

Basic Act for Gender-Equal Society (Japan) (1999) 39

Becker, G. 191

belonging 15, 157-158, 161, 163, 168-170

Berg, A.M. 143

birth rate: in Japan 9, 30, 84, 142, 176-178, 179, 197, 201, 225; in Norway 183-187; see also fertility and fertility rates

boardroom feminism 214; see also feminism

Bolsø, A. 9, 209-223; academic career 210-211; brief biography 209-210; family 211, 212-213, 222; feminism and academic career 216-217; on feminism in Norway 213-214; feminist mother 212-213; feminist research 219; on feminist theory 219-221; university experience in the 1970s 215-216

Borden, V.M. 106

Bottolfs, M. 75

Branlat, J. 7, 8, 9-10, 70-84, 123-137, 209-223

Bruner, J. 89-90

bubble economy, collapse of 29

bushido code 127

Butler, J. 220

Cannizzo, F. 105 
caring masculinity $36-50,136$, 218, 222

Carsten, J. 15

Center for Gender Studies (Trondheim, Norway) 3-4

child abuse 29

Child Care and Family Care Leave Law (Japan) (2010) 40

child killing 29

Childcare Leave Law (Japan) 39

Christian Democratic Party (Norway) 197, 200

Cieraad, I 16

cisgenderism 161

citizenship 161

condominiums 25

Confucian values of loyalty 28

Convention on the Elimination of All Forms of Discrimination Against Women (1979) 66, 74

Convention on the Elimination of all forms of Discrimination Against Women (CEDAW) 5

corporate feminism 214-215; see also feminism

corporate warrior 29, 127

COVID-19 pandemic 1, 8; advertisements during 144-146; domestic work in 146-148; gendered consequences of 146-147; Japanese versus Norwegian commercials in 148-150; work and home under 139-140; working from home in 146-148

cross-cultural research $2-5$

\section{datsu-sara 127}

Den Norske Bank 146-147

dialogical narrative approach $89-91$

dialogue 9-10

disciplinary teaching 91-93

Dobashi, A. 8

domestic skills 74, 81-83

Døving, R. 19

dual earner/dual carer model 20-22, 24, 31, 71, 74, 181, 219

education 7-8, 55-67; and economic growth 64-66; and employment of women in Japan 62-64; and gender $55-67,59,60$; gender equality in 57; higher education 56, 56, 58; home economics 70-84; index 55; overview
55-56; problems in universities 66-67; women's junior colleges in Japan 59-61, 60, 62

Education Reform Commission (Japan) (2010) 57

egg donation 9, 194-195, 198, 200-201; see also assisted reproduction technologies (ARTs)

Ellingsæter, A.L. 148, 183

Engesbakk, S. 144

eugenics 175, 184, 187

family 6-7; happy family myth in advertisements 148-149; home as territory of 18

family planning 9

fatherhood: industrialisations' effect on 37; in Japan 37; in Norway 36-37; urbanisation's effect on 37

fathers' childcare 36-50; antecedents 44-45; and caring masculinity 45; and educational attainment 45-48; and employment 45-48; factors predicting level of 43-48, 44, 49; father's quota system in Norway 37-39; history of Japanese fatherhood 37; history of Norwegian fatherhood 36-37; Japanese versus Norwegian statistics on 43; parental leave policy in Japan 39-42; structural equation model 48 ; and wives 47

father's quota system 37-39, 42

female students, in higher education 58 female workers, Japanese 62-64, 63, 63, 64

female workers, Norwegian 37, 63, 64, 147

Feminine Mystique (Friedan) 220 femininity $125,127,166,168,210$, 215,221

feminism 2, 9-10; boardroom feminism 214; and class 214-215; corporate feminism 214-215; Gucci feminism 214; and higher education 87-89, 96, 101-102; in Japan 213; in Norway 74; and pedagogy 88-89; and unbound learning spaces 100-103 feminist pedagogy $7,88-89,93,97$, 101-102

feminist theory $9,87,101,219-221$ fertility and fertility rates 9, 173-187; and adoption in Norway 183; and 
aging population in Japan 177; and cultural values in Japan 177; declining 173-174; and declining birth rate in Japan 176-178; and difficulties of raising children for women in Japan 178-180; and eugenics discourse 175; and global over-population 184-185; in Global South 173; and immigrants 183-184, 186; in Japan 173-181, 174; Japanese policy on 176-178; and Malthusian discourse 175; and national and/or individual responsibilities 184-185; in Norway 173-174, 174, 181-185; Norwegian policy on 181-183; and people as power discourse 175; and psychological pressure on women to procreate 180-181; and reproduction by ethnic Norwegians 183-184; world population 173

food and health curriculum 70 , $75,78-83$

Frank, A. 87, 89-90

Freire, P. 88

Friedan, B. 220

Furuichi, K. 83

Fusei no Fukken (Restoration of Paternity) (Hayashi) 37

Game of Thrones (television series) 123,125

Gamlund, E. 183

gender and education 55-67

gender bashing 213

gender equality: convergences and divergences in 225-226; crosscultural research 2-5; dual earner/ dual carer model 20-21; and home economics education $76,77,78$, $79-80$; idea of 228; in Japan and Norway 1-10, 224-228; and Norwegian homes 19-25; overview 1-2; reflections on 224; and state ideologies 226-227; as stress 21-25 gender gap index 55

Gender Gap Report 1-2, 228 gender identity diagnosis 160 gender identity disorder 159, 167 Gender Identity Disorder Special Cases Act (Japan) (2003) 160 gender inequality: in academic career 105; in housework responsibilities 148-149; in Japanese homes 27,
148-149, 221; and technologies 149-150

Gender Recognition Act (Norway) (2016) 159

gender studies 7, 87-103, 221; and activism 97-100; and alienation 93-94; dialogical narrative approach 89-91; disciplinary teaching 91-93; educator narratives 100-103; educators' role in 88-89; and feminism 100-103; feminism and 88-89; learning spaces 100-103; and life experiences 91-93; liminality in 96-97; overview 87-88; pedagogy of 88-89; and student resistance 93-94; transnational perspective on $87-88$

Gender Trouble (Butler) 220

gender-diverse individuals 157-171; attitude towards sterilisation 163-164; experiences of un/ acceptance 157-171, 165-167; in Japan 159-160, 164-165, 166-167, 169; in Norway 158, 163-164, 165-166, 168-169; overview 157; sense of belonging 168-170; and transfeminism 161-162; triad model 158

gender-free bashing 213

Gilligan, C. 216

Global Gender Gap Report 186

Guarino, C.M. 106

Gucci feminism 214; see also feminism

Gullestad, M. 18

Hansson, R. 184

happy family myth, in advertisements 148-149

hartline, f.r. 157-171

Hayashi, M. 37

Helgaker, J.I. 8, 124, 128-129, 134

higher education: female students in 58 ; and feminism 87-89, 96, 101-102; gender gap in 55,56 ; international comparisons 56; in Japan 57-61, 66-67; in Norway 55, 66-67, 73, 83; women's junior colleges in in Japan 59-61, 65-66

hikikomori (shut-in) phenomenon 27 , $125,130-132$

Hirvju, K. 125

historical Japanese home 27-30

home 6-7, 15-32; definition of 15; as family's territory 18 ; gender and 


\section{Index}

15-16; Japanese 25-32; Norwegian 16-25; overview 15-16; social meaning of 31-32

home décor 19, 27

home economics education 7, 70-84; from 2000 onward 74-76; basic home economics 75 ; and creativity in home life 80-81; and domestic skills 81-82; food and health curriculum 75,80 ; and gender equality 76 , 79-80; in high schools 75;

Japaneseness in 76; and modernisation of women's education 72-74; in Norwegian public school system 72-73; overview 70-72; in post-war Japan 73-74, 78; teachers' perspectives on 76

home ownership: in Japan 25-26; in Norway 17-19

home, Japanese 25-32; gendered division of household labour in 29; gendered inequality in 27; as gendered institution 27-30; historical 27-30; kitchen 28; living room 29; in Meiji period 28; modern home as gendered space 30-31; outsourcing of cooking 30; ownership 25-26; photograph 27; social meaning of $31-32$; trends in 27

home, Norwegian 16-25; concurrence between house and family 18; as family's territory 18; and gender equality 19-25; households 17-18; housewife era 19-21; identity 18-19; intimacy 18; kitchen 21; living room 20; overview 16-17; ownership 17-19; paid domestic labour 23-24; photographs 23, 24; post-war 17; size of 17-18; social meaning of $31-32$; time-bind in 23-24; traditional 22; trends in 17-19

House Foods 141

household labour see housework housewife era 19-21

housework: academic 106; in COVID19 pandemic 139-150; domestic skills for 81-82; gendered division of 29, $36,74,217,223$; in Japanese households 19-21, 27, 29, 30-31, 36, 71, 91, 186, 210-211, 217-218; men's participation in 19-21, 43, 47, 210-211, 217-218; in Norwegian households 47, 73, 74, 80, 83; rethinking 83
Human Development Index 1

humor 125-126

Husu, L. 107

identification 161

identity 161

ie system 28

ikemen (handsome men) 142

ikumen (Japanese child caring men) 127, 142, 210

Ikumen phenomenon 76

immigrants 2, 9, 32, 183-184, 186-187

In a Different Voice (Gilligan) 216

in vitro fertilisation (IVF) 191

Institute for Gender Studies (IGS) (Tokyo, Japan) 4

Inudô, I. 8

Ishii-Kuntz, M. 1-10, 6-7, 9, 15-32, 76, 209-223, 224-228; academic career

211-212; brief biography 209-210;

family 222-223; feminism and academic career 216-217; on feminism in Japan 213; feminist research 218; on feminist theory 220-221; university experience in the 1970s 216

Ishimaru, K. 8-9, 157-171

Japan: birth rate in $9,30,84,142$, 176-178, 179, 197, 201, 225; LGBTQ activism in 159-160, 170

Japan Society of Obstetrics and Gynecology (JSOG) 194-195

Japanese films 4-5

Japanese salaried men see salaryman

Japanese women 157-171; in higher education 58; home as venue of creativity 31 ; housework 148 ; junior colleges for 59-61, 62, 66; labour force participation in 30; professors 115; psychological pressure to procreate 180-181; raising children 178-180; work-life balance 187, 225

Jasanoff, S. 191, 192

jidaigeki 123

junior colleges 59-61, 62

Kanaaneh, R.A. 184

Kano, A. 74

kigyo senshi (corporate warrior) 29, 127

Kitterød, R.H. 71, 148

Kodama, R. 7, 55-67 
Kollontai, A 220

Kondo, M. 83, 132-133

KonMari method 83

koseki (family register) 160

Kristensen, G.K. 1-10, 6, 8, 9, 15-32, 104-116, 173-187, 224-228

Kureha Corporation 145-146

Labour Party (Norway) 198

Lagesen, V.A. 8, 104-116

Law on Artificial Conception (Norway) (1987) 197

Law on Medical Use of Biotechnology (Norway) 197-198

learning spaces 100-103

LGBTQ activism 2; in Japan 159-160, 170

LGBTQ+ households 144

Lie, M. 9

life experiences 91-93

liminality 96-97

Lindholm, J.A. 105

Lock, M.M. 192

Luxemburg, R. 220

Makino, K. 30

Malthusian discourse 175, 187

Mangen, S. 3, 4, 225

masculinity 215; caring 36-50, 218, 222; and femininity 221; hegemonic 42, 142, 159; hikikomori 130-132; of infertile men 194, 200; in Japan 159, 169; and men's childcare involvement 45; in Norway and Japan 126-136; overview 8; and queerness 169; salaryman 126-127, 130-132; and women's situation 219

material cultural locality 161

maternal instinct myth 30

Matsuda, D. 8, 104-116

media 8

Meiji Civil Code (1889) 25, 226

Meiji period 28

menopause 192-193

meritocrats 215

Ministry of Health, Labour and Welfare (Japan) 142

Morris 88

Mulky, M. 125

Murphy, P. 102

Nagai, K. 30 noisy children trope, in advertisements 147

nomikai 142

Nonaka, M. 75

Norsemen/Vikingane 123-137; humor in 125-126; men in double-bind in 133-136; opening sequence 124 ; overview 123-124; sensitive men wielding weapons in 128-130

Norway: educational system in 57 ; fertility rates in 173-187, 174; transspecific policies in 159-160

Norway, gender equality in 1-2; historical review 5

Norway-Japan: Bridging Research and Education in Gender Equality and Diversity project 3-4

Norwegian Association for Women's Rights 5

Norwegian Biotechnology 198-199

Norwegian University of Science and Technology (NTNU) 4

Norwegian women: academic career of 106; domestic work in COVID-19 pandemic 148, 149; professors 113, 115; raising children 182; work-life balance 71, 187, 225

Ochanomizu University 4

On Humour: Its nature and its place in modern society (Mulkay) 125

'1.57 (fertility) shock' of 198937

Oocyte Donation Network (ODNet) 195

Overell, R. 132

paid domestic labour 23-24

Papa Mama Childcare Plus initiative (Japan) (2010) 40, 41

parental leave: duration of 42,42 ; father's quota system 37-39, 42; gender differences 40, 41; Japanese policy on 39-42, 50; Norwegian policy on 37-39, 41, 50; use-it-orleave it 37

pedagogy $88-89$

people as power discourse 175

professional housewives 29

professorships 104-116; academic career trajectories 107-108; gender balance 107-108; gendered division of work and 106; overview 104-105; passion in 109-110; personal 


\section{Index}

sacrifices in 109-110; psychosocial aspects 104-105; social capital and 105; STEM disciplines 107; support system for women academics 108 ; supported inclusion in 111-113; and women in academia 105-106; and work-life balance 113-115

queer theory 2; see also LGBTQ activism

Rappoport, L. 125-126

reflexivity 3,226

reproduction 8-9; see also assisted reproduction technologies (ARTs); fertility and fertility rates

Reproductive Medicine Civil Code Special Law (Japan) (2020) 196-197

Research Council of Norway 219

Ringrose, P. 1-10, 6, 8, 15-32, 123-137, 224-228

Riordan, S. 105

Roberson, J. 127

Rønsen, M. 71

salaryman 125-128, 130-132, 134, 141-143, 150, 187

Salway, S.M. 3, 226

Samurai Shifters/Hikkoshi Daimyo 8, 123-137; de-cluttering strategy in 132-133; dilemma of 130 ; hikikomori masculinity in 130-132; humor in 125-126; men in doublebind in 133-136; opening sequence 124, 131; overview 123-124; salaryman in 130-132; sensitive men wielding weapons in 130

Sano, J. 70-84

School Act (Norway) (1959) 57

Schulman, L. 89

self-determination model 159

Semba, Y. 9, 173-187

seppuku 132

sex reassignment surgery 158

Sexual Orientation Anti-Discrimination Act (Norway) (2013) 159

sexuality $2,8-9,95,102,224$; and feminism 87, 214, 220; in Japan 126-127; and reproduction 8-9, 200; research 210-211, 219

Shariati, F. 183

Silverman 3

single households 144 social capital 105, 162

Solberg, E. 1, 181-182

Søraa, R.A. 8, 139

Sørensen, S.Ø. 8, 104-116

Sørheim, M. 185

sperm donation 9, 193-194, 200-201; see also assisted reproduction technologies (ARTs)

state feminism 227

Statens loererinneskole for husstell (The State Teacher Training School for Housekeeping) 73

STEM disciplines 107

sterilisation 163-165

Stommel 88

structural equation model (SEM) 48

student resistance 93-96

Suntory Beverage \& Food Limited 143

Sustainable Development Goals (SDGs) 72

Suzuki, M. 127, 192

Taga, F. 127

Telenor 143

Telia 146

three-year-old myth 28

Tidying up with Marie Kondo (television series) 132

time-bind 23-24

Toivonen, T. 41

Torgersen, J. 8, 124, 128-129, 134

Train Man/Densha Otoko 132

trans people 3, 8-9

transfeminism 161-162

transgender: attitude towards sterilisation 163-164; experiences of un/acceptance 165-167; in Japan 159-160, 164-165, 166-167, 169; in Norway 158, 163-164, 165-166, 168-169; overview 157; sense of belonging 168-170; and transfeminism 161-162; triad model 158

transsexualism 158-159

triad model 158

2LDK 25

Ueno, C. 101-102

UNIQLO 145-146

universities: enrollment rates 58,59, 60, 61; problems in 66-67

Vik, F.N. 75 
Vikings (television series) 8

Wada, C. 8, 139

Woman Lib 5

women's government, in Norway 74

women's studies see gender studies work-life balance 113-115

Yahiro, N. 195

Yuval-Davis, N. 174-175, 187 


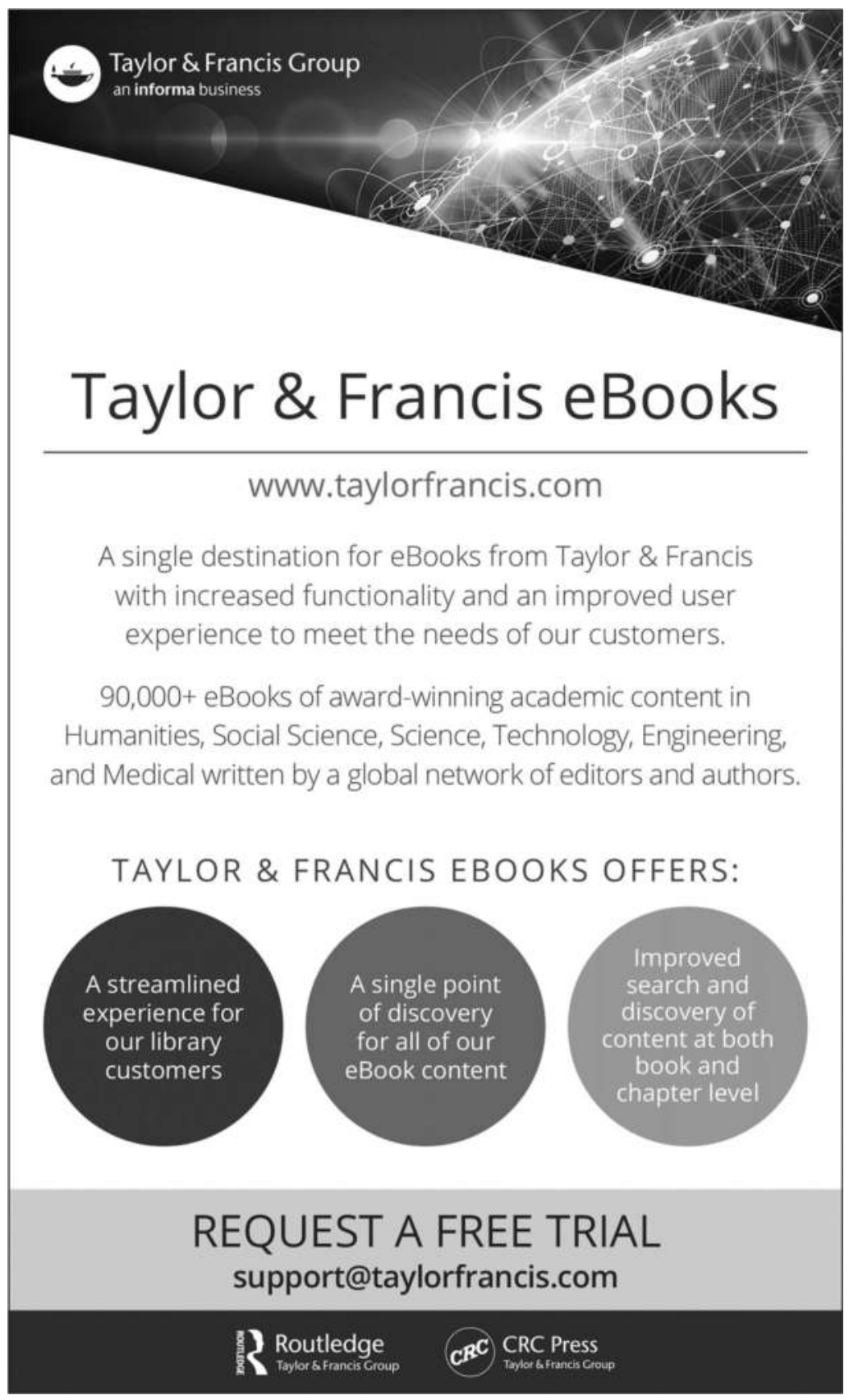

